Florida International University FIU Digital Commons

FIU Electronic Theses and Dissertations

University Graduate School

$10-21-2016$

\title{
The Western Sahara and the Search for the Roots of Sahrawi National Identity
}

David Suarez

Florida International University, dasuarez@fiu.edu

DOI: 10.25148 /etd.FIDC001212

Follow this and additional works at: https:// digitalcommons.fiu.edu/etd

Part of the African Studies Commons, Comparative Politics Commons, Near and Middle Eastern Studies Commons, Politics and Social Change Commons, and the Race and Ethnicity Commons

\section{Recommended Citation}

Suarez, David, "The Western Sahara and the Search for the Roots of Sahrawi National Identity" (2016). FIU Electronic Theses and Dissertations. 3010.

https://digitalcommons.fiu.edu/etd/3010

This work is brought to you for free and open access by the University Graduate School at FIU Digital Commons. It has been accepted for inclusion in FIU Electronic Theses and Dissertations by an authorized administrator of FIU Digital Commons. For more information, please contact dcc@fiu.edu. 


\section{FLORIDA INTERNATIONAL UNIVERSITY}

Miami, Florida

THE WESTERN SAHARA AND THE SEARCH FOR THE ROOTS OF SAHRAWI NATIONAL IDENTITY

A dissertation submitted in partial fulfillment of the requirements for the degree of DOCTOR OF PHILOSOPHY

in

INTERNATIONAL RELATIONS

by

David Suarez 
To: Dean John F. Stack, Jr.

Steven J. Green School of International and Public Affairs

This dissertation, written by David Suarez, and entitled The Western Sahara and the Search for the Roots of Sahrawi National Identity, having been approved in respect to style and intellectual content, is referred to you for judgment.

We have read this dissertation and recommend that it be approved.

Charles G. MacDonald

Oren B. Stier

Mohiadin Messbahi

John F. Stack, Jr.

John F. Clark, Major Professor

Date of Defense: October 21, 2016

The dissertation of David Suarez is approved.

Dean John F. Stack, Jr. Steven J. Green School of International and Public Affairs

Andrés G. Gil

Vice President for Research and Economic Development and Dean of the University Graduate School

Florida International University, 2016 


\section{DEDICATION}

I dedicate this dissertation to my wife, Paola. Without her patience, understanding, and support, this work would have not have been possible. 


\section{ACKNOWLEDGMENTS}

I wish to thank the members of my committee for their support, patience, and commentary. Their guidance has been most appreciative. I also wish to thank Dr. Maria Antonieta Garcia for her aid in the translation of several French passages into English. I am grateful to my proofreader for her efforts in improving the language of the dissertation. Finally, I am indebted to my major professor, Dr. John Clark, for his immense patience, confidence, and his efforts in helping me successfully complete my dissertation. 


\section{ABSTRACT OF THE DISSERTATION \\ THE WESTERN SAHARA AND THE SEARCH FOR \\ THE ROOTS OF SAHRAWI NATIONAL IDENTITY}

by

David Suarez

Florida International University, 2016

Miami, Florida

Professor John F. Clark, Major Professor

This work is a socio-historical study of the roots of Sahrawi national identity. The Sahrawi are a community of people who live in the Western Sahara, a former Spanish colony. Most of its territory has been occupied since 1975 by Morocco, which denies the existence of a distinctive population inhabiting the Western Sahara. In contrast, the POLISARIO Front, vanguard of the Sahrawi nationalist movement, argues that the Western Sahara belongs to the Sahrawi and seeks its full independence. It bases its claims on the notion of a distinctive history, language, and culture for the Sahrawi, separate from that of Moroccans.

The central question of this study asks, "What are the origins of Sahrawi national identity?" This study provides a detailed account of Sahrawi identity formation and how it has developed in intensity and scope. It renders a clear understanding of the Sahrawi phenomenon, useful to the international community in its deliberations on the validity of their nationalism. This study examines the foundation of Sahrawi identity through three different theoretical lenses, namely, primordialism, instrumentalism, and constructivism. The study analyzes arguments derived from each of these theoretical approaches, acknowledging the diversity of arguments about the sources of national identity. This study also demonstrates how a national identity can develop over a long period of time as a succession of layers. This study locates the final moment of Sahrawi identity formation in the twentieth century, but adds that this conclusion utilizes 
essential markers of differentiation that persist over time - the building blocks of any national identity. 


\section{TABLE OF CONTENTS}

CHAPTER

PAGE

\section{INTRODUCTION}

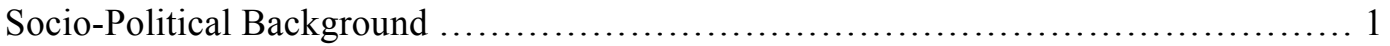

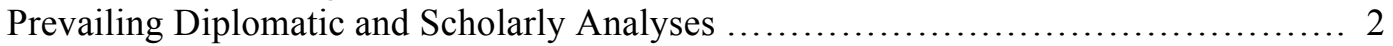

Problem of Sahrawi Nationalism .............................................. 3

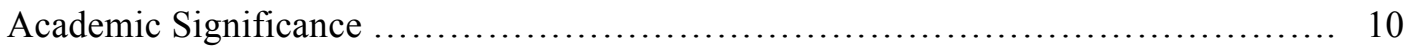

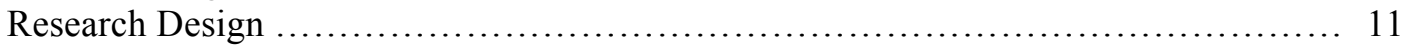

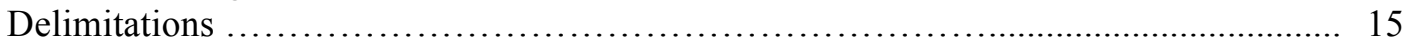

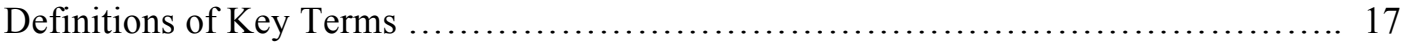

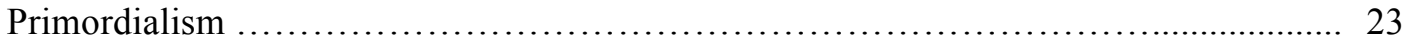

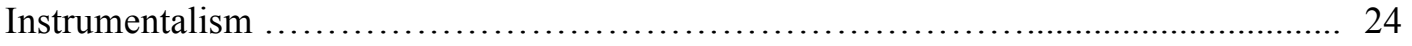

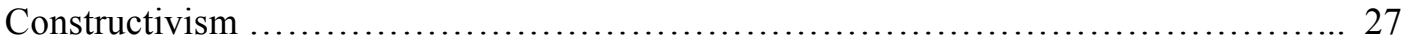

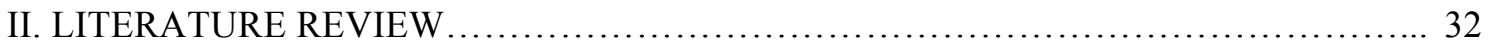

Theoretical Research.......................................................... 36

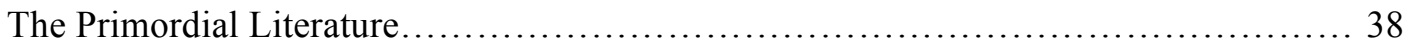

Sahrawi History................................................................. 41

III. ARE THE SAHRAWI OF ANCIENT ORIGIN? INVESTIGATING THEIR

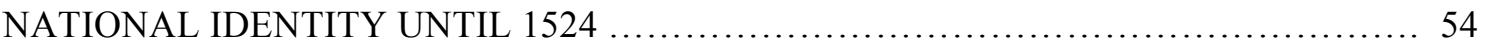

The Lybico-Berbers: Proto-Sahrawi Nation? Ancient Origins - 1000 BCE............... 55

The Gaetulian Berbers of Northwest Africa - 500 BCE to the Arab Invasion .............62 62

Sanhaja Berber and Early Islamic Dynastic Rule — From the Fourth Century

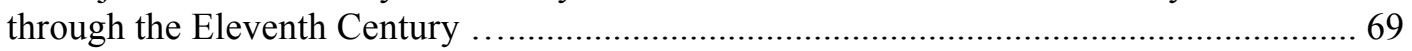

The Great Berber Dynasties — From the Eleventh to Thirteenth Centuries ............. 76

The Great Sanhaja Divide .................................................... 79

Arab Dominance and the First Europeans: Thirteenth to Sixteenth Centuries............. 85

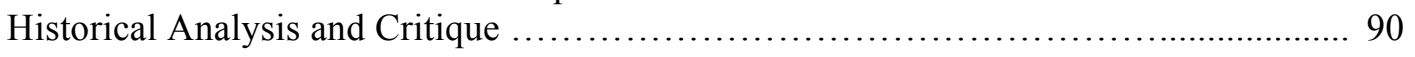

IV. SAHARAN IDENTITY: DYNASTIC OR TRIBAL? $(1524-1757) \ldots \ldots \ldots \ldots \ldots \ldots \ldots$

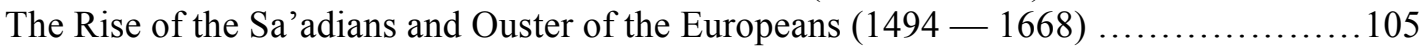

The Saadians: The First Links to the Sahrawi? .................................. 108

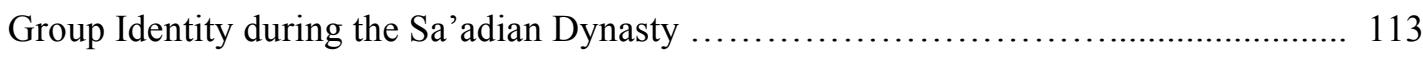

Sanhaja Identity after the War of Shar Bouba .................................. 118

The Alawite Sultanate 1669 - 1757: Contentious Concepts of Identity

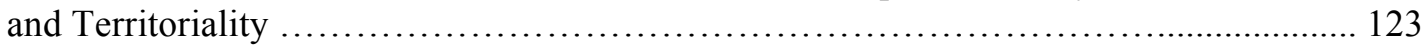

\section{SAHARAN HISTORY: SEARCHING FOR SAHRAWI}

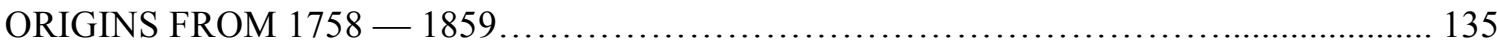

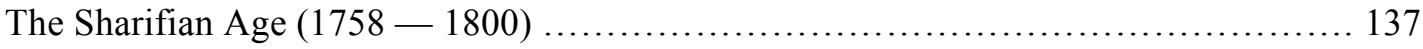

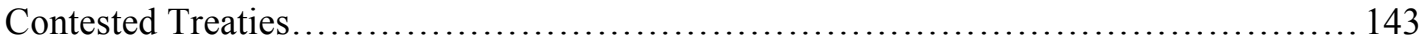

The Lands of Dissonance and of the White Moors................................ 149

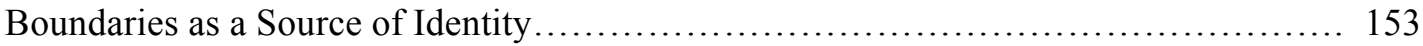

Saharan History as Identity: Tribal Independence............................... 158

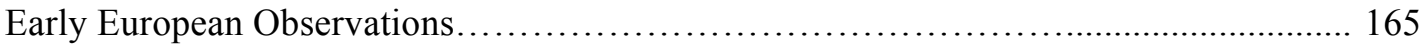




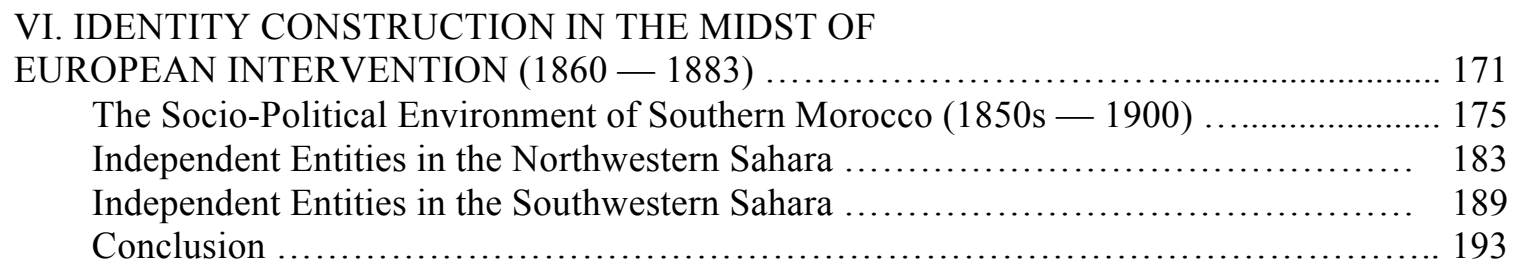

VII. A NEW POPULATION EMERGES: THE DAWN OF

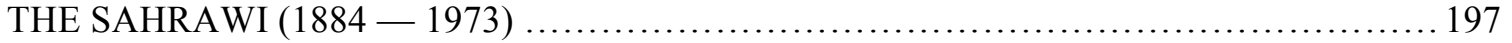

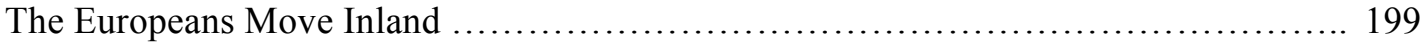

Tribal Distinctiveness .............................................................. 207

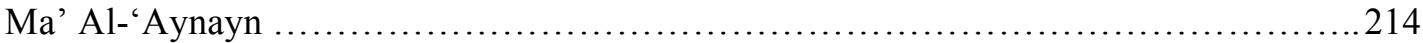

The Sahrawi Dawn .............................................................. 217

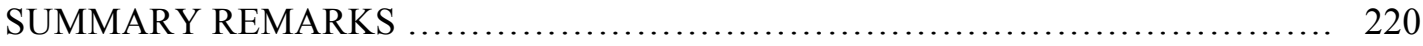

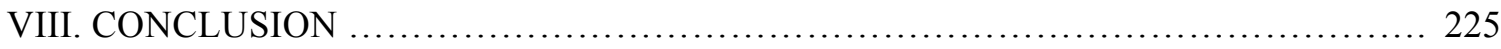

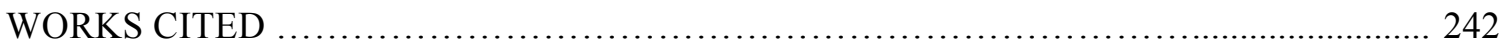

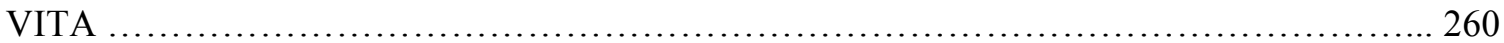




\section{LIST OF FIGURES}

FIGURES

PAGE

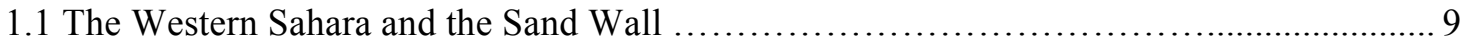

3.1 African Antiqua Showing Ancient Groups in Northwest Africa ............................. 67

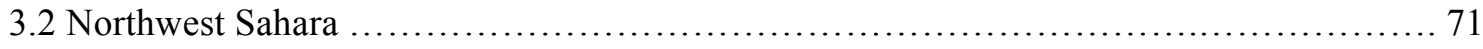

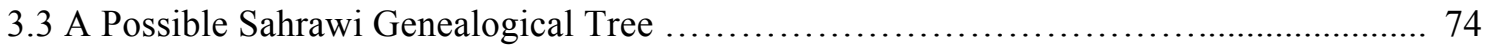

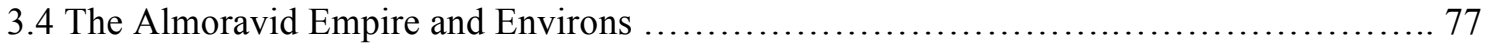

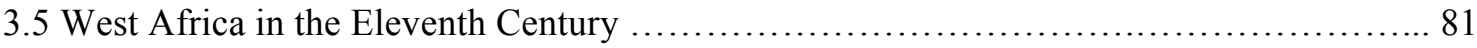

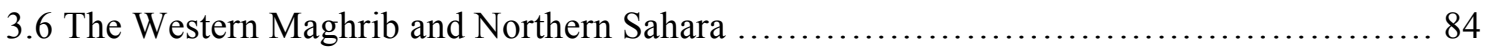

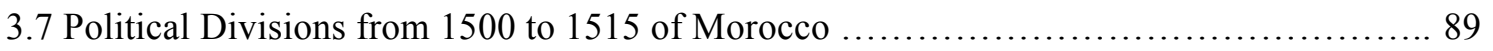

4.1 Early Colonization of Morocco in the Sixteenth Century .......................... 100

4.2 Morocco During the Wattasid Dynasty ............................................. 102

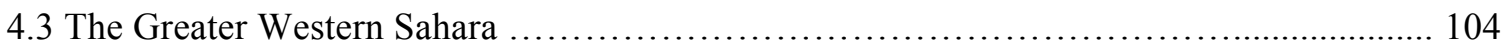

4.4 The Wattasid and Sa'adian Quest for Control of Morocco........................... 107

4.5 Greater Western Sahara in the Sixteenth Century ....................................... 115

4.6 Morocco in the Sixteenth and Seventeenth Centuries ............................... 124

5.1/5.2 Comparison of Modern-Day Morocco with 'Morocco' in $1600-1822$...................... 138

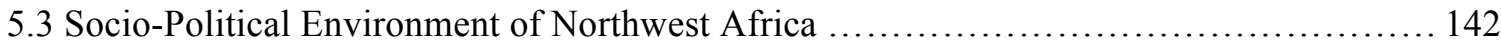

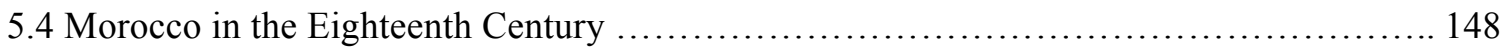

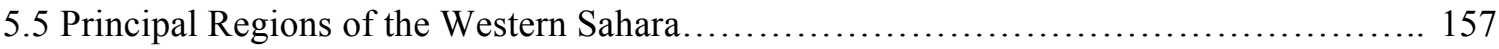

6.1 Map of the People of the Senegal (Carte des Peuples du Sénégal) ....................... 174

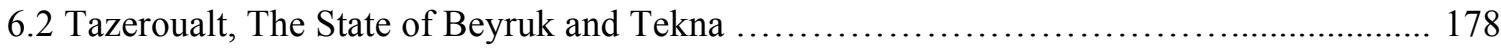

6.3 Morocco 1894: Sultanate of Morocco and Rio de Oro Colony .............................. 187

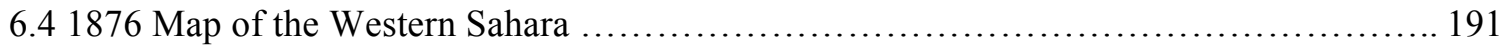

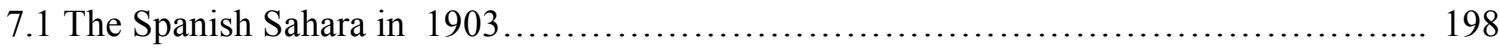


7.2 1912 Territorial Distribution of Western Sahara

7.3 Location of Majority Hassaniya Speakers 


\section{INTRODUCTION}

This dissertation is a socio-historical study of Sahrawi national identity. The study aims to explore the roots of Sahrawi nationalism and discuss the arguments for independence of the Western Sahara. Although there have been several studies on Sahrawi nationalism, most have focused on the current territorial stalemate. Reports, memos, and other documents discuss the issue of the Western Sahara as an indeterminable conflict based on the intransigence of both parties involved: the Kingdom of Morocco and the Frente Por la Liberación de la Saguia El Hamra y Río del Oro (POLISARIO ${ }^{1}$ ). More meaningful discussions of the claims of the Sahrawi are found in passages or chapters that attempt to trace a historical account of Sahrawi nationalism. Despite these attempts, there is not one work that has evaluated the sources of national identity or contextualized them in any type of theoretical framework. Accordingly, this socio-historical case study will incorporate a theoretical framework that will be useful for approaching both the question of the Sahrawi and other nationalism studies.

\section{Socio-Political Background}

The problem of the Western Sahara traditionally seemed to be very isolated and largely disregarded by the international community. The geo-political environment has recently changed, however, even if the dilemma remains localized to northwest Africa. Over the last ten to fifteen years, the "Berber movement" has gained new ground in its quest for recognition in language and culture. $^{2}$ The Sahrawi, who have claimed to be descendants of the Berber, have appropriated these goals for their own cause and have sought an independent land, separate from the Kingdom

\footnotetext{
${ }^{1}$ POLISARIO is the Spanish acronym for the Frente Popular de Liberación para Saquiat el-Hamra y Río de Oro (Popular Front for the Liberation of Saquiat el-Hamra and River of Gold). The POLISARIO is the former militant, now guardian entity spearheading the independence of the region, claimed and administered by the Kingdom of Morocco, called the Western Sahara.

${ }^{2}$ Berbers seek not only more autonomy in certain regions of North Africa (Kabylia, the Atlas Mountain region in Morocco, and across much of the Sahel) but also more protection for their cultural rights - specifically in language and custom.
} 
of Morocco. In the last ten years, the imminent threat from Islamists groups affiliated to AQIM and MUJAO has transformed the Western Sahara from a narrow bilateral dispute to a transborder regional security dilemma. Reports from the Sahrawi refugee camps in Tindouf, Algeria, have indicated that militias fighting in northern Mali have recruited several youths. These militias are loosely affiliated with the Islamist networks that prey on the disgruntled and restless younger generation and may begin to threaten the security of not only the region but also the nature of the conflict over the Western Sahara.

\section{Prevailing Diplomatic and Scholarly Analyses}

Much of the discussion concerning the Western Sahara involves the POLISARIO movement, Morocco's repression of the Sahrawi within its administrative borders, or historical accounts leading up to the current political stalemate. Intermittent work on Sahrawi nationalism has revolved around the origins of Sahrawi national identity. A few of these studies have criticized and questioned the origins of their nationality. At the beginning of this endeavor, the present writer was told that 'a lot had already been written about' Sahrawi nationalism. Despite these claims, my research has discovered that of the several documents and volumes discussing the Western Sahara, only a handful focus on Sahrawi nationalism. The biggest issue among these authors has been the lack of theoretical analysis to support the claims of either the POLISARIO or those who cast doubt on the veracity of POLISARIO claims. Much has been assumed in the literature, and little has been offered as an explanation of how Sahrawi identity had been formed or how it evolved into nationhood.

The research corpus on the topic is small, especially from scholars in North America. Most of the work related to the Western Sahara can be found in European libraries. Almost all of those studies are either in Spanish or French. The scant research in English usually includes the Western Sahara as a sample among regional studies of the Middle East or as a case issue in 
nationalism. American scholarship has been marginal. Although the most comprehensive recent writings concerning the Sahrawi come from scholars such as Zunes and Mundy (2010), American monographs or books detailing this topic are scarce. An even wider deficit in the literature exists in the theoretical grounding of these few works. Most discussion over the Western Sahara focuses on either legal (ICJ rulings, UNSC resolutions), political (Morocco's policy of inclusion/development of the 'southern provinces,' UN-sponsored talks), and socio-economic features (Sahrawi demographics, the Sahrawi refugee problem, and the human rights dimension) of the conflict. Those involved in the dispute in Morocco, Europe and the U.S. consider it a political issue, not an ethnic, linguistic, or territorial problem. The overwhelming majority of writers approach the Sahrawi problem by ignoring or assuming incorrectly the origins of Sahrawi identity. Those who consciously consider the problem of Sahrawi nationalism tend to use the more popular constructivist notions of nationalism uncritically. Other approaches have largely been disregarded and therefore existing studies provide an incomplete picture. Thus, the intent of this study is not only to make this issue more prominent in North America and more accessible to English-speaking scholars, but also to provide an in-depth theoretical approach to Sahrawi identity.

\section{Problem of Sahrawi Nationalism}

The Western Sahara, located in northwest Africa, has been the site of one of the longest-running international disputes on the African continent. At the moment, there is a bitter, though nonviolent, stalemate between the Kingdom of Morocco and the region's people, the Sahrawi. The latter are represented by the leaders of the POLISARIO, who have claimed independence for the Western Sahara. This project investigates Sahrawi nationalism by answering a central question (CQ), namely: "What are the origins of Sahrawi national identity?" Most contemporary literature suggests that Sahrawi identity, as a nationalist movement, has been socially constructed through 
variable subjective factors. However, the key players of the independence movement stress more objective elements to propel their independence struggle. Without understanding from whence and why parties to the conflict take these approaches to discussing the roots of Sahrawi national identity, it is difficult for scholarly analysts to get a clear picture of the real origins of Sahrawi nationalism.

The struggle of the Sahrawi for control over the Western Sahara began well before Spanish colonization in the late 1880s. The European powers began to encroach on the coasts of Morocco and the rest of northwest Africa through commercial ventures and journeys of exploration in the mid-1800s. Spain, for instance, attempted to stake claims in various locations off the coast of the Western Sahara primarily to prevent other powers from gaining the upper hand in Africa. However, the 1884-1885 Berlin Conference gave the Great Powers a 'justifiable' argument to take not only coastal emplacements in Africa but also its interior lands so long as the original inhabitants acquiesced to their rule. Of course, these decisions were discussed without the consent of any African representatives. Thereafter, several treaties $(1860,1904,1912)$ were agreed upon between the Great Powers and the Sultanate of Morocco delineating Spanish and French possessions in northwest Africa. By 1934, the Spanish zones were placed under the control of the High Commissioner for Spain in Morocco (López-Pozas Lanuza 2015, 69). In 1946, África Occidental Española (AOE) or the Spanish West Africa administrative unit was established to integrate all of its northwest African zones. Although intermittent revolts against Spanish and French rule were put down, the population of the Western Sahara once again began to rebel after Morocco won its independence in 1956.

The crisis in Spanish leadership and the momentous 'Green March'3 decision taken by King Hassan II of Morocco produced the Madrid Accords ${ }^{4}$ of November 1975. Spain formally

\footnotetext{
${ }^{3}$ The Green March (al-Massira al-Khadra) was "a well-coordinated procession by some 350,000 Moroccan civilians" and government officials "into Western Sahara" on 21 October 1975. "The Green March was instrumental in pressuring Spain into abandoning its plans for self-determination in its last African colony and to arrange for the
} 
withdrew from the region and ceded administrative control of the Spanish Sahara to Morocco and Mauritania in 1976. Morocco and Mauritania partitioned the Western Sahara between them, and the POLISARIO relocated to Algeria. ${ }^{5}$ However, before Spain committed itself to leaving the Western Sahara, Morocco had approached the International Court of Justice (ICJ) to adjudicate its and Mauritania's claims over the territory. The UN had already determined in 1965 "that both Ifni and the Saharans had the right to freedom from 'colonial domination' and called on Spain to 'enter into negotiations on the problems relating to sovereignty presented by these two Territories" (Jensen 2005, 25). The King of Morocco had offered Spain to jointly appeal to the ICJ in late $1975,{ }^{6}$ but Spain "proved unwilling" (Jensen 2005, 27). Nevertheless, Morocco presented the case to the UN in October of 1974. Subsequently, the UN General Assembly adopted a resolution to have the ICJ hear the case. The ICJ deliberated between 13 December 1974 and 16 October 1976. The final ruling by the Court stated that,

The materials and information presented to it [the ICJ] do not establish any tie of territorial sovereignty between the territory of Western Sahara and the Kingdom of Morocco or the Mauritanian entity. Thus the Court has not found legal ties of

territory to be instead partitioned between Morocco and Mauritania with no role for either the POLISARIO Front or the [Sahrawi] people generally." The March along with the domestic crisis caused by the terminal illness of Spain's leader Generalissimo Francisco Franco led Spain to "accede to Rabat's wishes and sign the Madrid Agreement on" 14 November 1975, "which provided for Madrid's full and final withdrawal from the Western Sahara by late February 1976. Anthony G. Pazzanita, Historical Dictionary of Western Sahara, Third Edition, s.v., "Green March," (Lanham, MD: The Scarecrow Press, 2006), 178-179.

${ }^{4}$ The Madrid Accords are also known as the "Declaration of Principles on Western Sahara by Spain, Morocco, and Mauritania." United Nations Treaty Collection, Declaration of Principles on Western Sahara by Spain, Morocco and Mauritania, Vol. 988, No. 14450 (New York: United Nations, 1983), 259, accessed June 15, 2012, http://peacemaker.un.org/sites/peacemaker.un.org/files/MA-MR-

ES 751114 DeclarationPrinciplesOnWesternSahara 0.pdf. Also found in the UN Dag Hammarskjöld Library, UN Security Council Third Report by the Secretary-General in Pursuance of Resolution 379 (1975) Relating to the Situation Concerning Western Sahara, DAG Digital Library, S/11880, 19 November 1975, accessed May 25, 2016, http://repository.un.org/bitstream/handle/11176/71032/S 11880-EN.pdf?sequence=2\&isAllowed=y. However, "the full text of the agreement was never published, either at the time or at any point since." Pazzanita, Historical Dictionary of Western Sahara, s.v., "Madrid Agreement (Of November 14, 1975)," 248.

${ }^{5}$ Previously, the origin and base of operations for the POLISARIO was in Mauritania (or along the border with Mauritania and the Western Sahara, but the group subsequently relocated to Algeria after the Madrid Accords

${ }^{6}$ The King of Morocco foresaw (incorrectly) that the population would join with the Kingdom if allowed to determine its fate. Erik Jensen, Western Sahara: Anatomy of a Stalemate (Boulder, CO: Lynne Rienner Publishers, Second, 2005), 27. 
such a nature as might affect the application of resolution 1514 (XV) in the decolonization of Western Sahara and, in particular, of the principle of selfdetermination through the free and genuine expression of the will of the peoples of the Territory (ICJ Reports 16 October 1975, 162).

Both Morocco and Mauritania largely interpreted the 1975 ruling in their favor whereas the POLISARIO claimed that the judgment by the ICJ was undeniable proof of the right of Sahrawi self-government. Morocco's King Hassan II did not waver in his attempt to claim the Western Sahara and despite the World Court's ruling, pushed ahead with the Green March. The King declared on 16 October 1975, in one of his speeches:

Yes, dear people, our law has been acknowledged and the International Court of Justice answered the questions ... the Sahara has never been "terra nullius" before the Spanish occupation ... It recognizes the existence of legal ties of sovereignty and allegiance between the kings of Morocco and the Sahara populations ... so there were legal ties and ties of allegiance ... Because the word allegiance is best suited to the period during which the Sahara was occupied ... the doors of the Sahara are legally open for us, everyone has recognized that the Sahara belongs to us since the dawn of time. so we have to occupy our territory ${ }^{7}$ (Portail Du Sud Marocain 16 October 1975).

Thus, the King's interpretation was grounded, not on the western conception of sovereignty and statehood, but on Islamic juridical tradition. This interpretation hinges on the use of 'allegiance.' "The act of allegiance made by subjects to the King was tantamount to a collective recognition that the king is the sovereign, the temporal leader whose legitimacy is at once hereditary and spiritual” (ICJ 2007, 2). However, King Hasan II appeared to set aside the rest of the ICJ's conclusions. Mauritania, for its part, agreed with the King's sentiments as they had already colluded with Morocco to partition the Western Sahara.

\footnotetext{
${ }^{7}$ Translated from the French by the Dr. Maria Antonieta Gracia: "Effectivement, cher peuple, notre droit a été reconnu et la Cour internationale de justice a répondu aux questions ...le Sahara n'a jamais été 'terra nullius' [belonging to no one] avant l'occupation espagnole...Elle reconnaît l'existence de liens juridiques de souveraineté et d'allégeance entre les Rois du Maroc et les populations du Sahara...Il y avait donc des liens juridiques et liens d'allégeance... Car le mot allégeance est le mieux adapté à la période au cours de laquelle le Sahara a été occupé... Les portes du Sahara nous sont juridiquement ouvertes, tout le monde a reconnu que le Sahara nous appartient depuis la nuit des temps. Il nous reste donc à occuper notre territoire." Portail Du Sud Marocain, Discours de feu Sa Majesté Hassan II (Le 16 octobre 1975 à Marrakech), accessed May 23, 2016, http://www.agencedusud.gov.ma/download/discours-SM-HassanII-75marrakech.pdf.
} 
The ensuing conflict pitted the Moroccan Royal Armed Forces (FAR) ${ }^{8}$ and Mauritanian military against the military wing of the POLISARIO, the Ejército de Liberación Popular Saharaui (ELPS). ${ }^{9}$ The weaker Mauritanian military endured POLISARIO raids on their fragile iron ore mining facilities, attacks on their key Zerouate-Nouadhibou Railway line, and political/terror attacks in their capital, Nouakhchott, which damaged their mainly export-based economy. Even with French Air Force intervention, ethnic divisions, economic losses, and military setbacks led to the overthrow of the Mauritanian government by a military junta on 10 July 1978 (Damis 1983, 86). Mauritania withdrew from the Western Sahara after signing the Algiers Agreement with the POLISARIO Front on 5 August 1979 (Jensen 2005, 22). With this agreement, Mauritania also renounced its claims to the Western Sahara and left Morocco as POLISARIO's only antagonist. With military support from Algeria and Libya the ELPS managed to hold and, at times, take control of certain towns in the Western Sahara and southern Morocco until the construction of a massive sand berm was completed in 1987, which divided the land and brought the conflict to a stalemate. ${ }^{10}$

The Organization of African Unity (OAU), today reconstituted as the African Unity (AU), along with the UN had previously pressured Spain for decolonization of their possessions in Africa. The AU did not directly become involved until the war broke out between the POLISARIO Front and both Morocco and Mauritania in 1976. The AU unsuccessfully attempted to mediate and provide for a process of decolonization in 1979 and 1980 using a select Comité des Sages (Wise Men Committee) (Aggad and Toit Botha 2005, 70). In 1982, the AU admitted

\footnotetext{
${ }^{8}$ Forces Armées Royales Marocaines.

${ }^{9}$ Translated into English as the Sahrawi People's Liberation Army or SPLA. It is considered to be the armed forces of the POLISARIO.

${ }^{10}$ In addition to construction of the sand berm by Morocco, the geo-political consequences brought about by the end of the Cold War (1989-1990) severely curtailed support for the POLISARIO Front. The disintegration of the Soviet Union in 1991 and the beginning of the Algerian Civil War with the Front Islamique du Salut (FIS) diminished both diplomatic and direct military aid to the POLISARIO.
} 
the Sahrawi Arab Democratic Republic $(\mathrm{SADR})^{11}$ to its organization in response to Morocco's inflexibility (Ohaegbulam 2002, 92). The SADR was formally seated at the AU Summit of 1984 in Addis Ababa because of overwhelming support by member states, but the Kingdom of Morocco protested vehemently and became the only country to officially leave the continental organization that same year (Pazzanita 2006, 314).

Since 1991, a cease-fire between the parties (Morocco and the POLISARIO) has been in place and is monitored by a UN mission called MINURSO. ${ }^{12}$ Direct UN intervention in 1990 attempted to bridge the differences between the parties, and by 1991 the UN had resolved to organize a referendum ${ }^{13}$ over the territory's future. Despite mediation efforts by several notable envoys appointed by the UN, the world organization has failed to reach an arrangement between the POLISARIO and Morocco that would allow for a referendum. Thus, instead of the referendum process clarifying the status of the region, the issue has become more contested and has opened the debate about who exactly is a true Sahrawi. Estimates of eligible Sahrawi voters have been muddled by Moroccan settlers in the Western Sahara and 'Sahrawi' who live in

\footnotetext{
11 The Sahrawi Arab Democratic Republic was the government formed by the POLISARIO Front in 1976. Other notations define the SADR acronym as the 'Saharan Arab Democratic Republic.' In this study, the 'S' will be referred to as Sahrawi.

${ }^{12}$ MINURSO, Mission des Nations Unies pour l'Organisation d'un Référendum au Sahara Occidental (The United Nations Mission for the Organization of a Referendum in the Western Sahara), "was established by UN Security Council resolution 69 [sic] of 29 April 1991, in accordance with 'the settlement proposals', as accepted on 30 August 1988 by Morocco and the" POLISARIO Front. "The Secretary-General's implementation plan, approved by the Security Council, provided for a transitional period during which the Special Representative of the Secretary-General would have sole and exclusive responsibility over all matters relating to a referendum in which the people of Western Sahara would choose between independence and integration with Morocco. The Special Representative would be assisted in his tasks by a deputy special representative and by an integrated group of United Nations civilian, military and police personnel, to be known as the United Nations Mission for the Referendum in Western Sahara." United Nations, MINURSO_United Nations Mission for the Referendum in Western Sahara: MINURSO Mandate, updated 27 May 2016, originally accessed March 22,
} http://www.un.org/en/peacekeeping/missions/minurso/mandate.shtml .

${ }^{13}$ Based on UN Resolution 621 (20 September 1988), UN Reports on The Situation Concerning the Western Sahara in S/21360 (18 June 1990), page 9, paragraph 23, stating that, “...a referendum will be organized in Western Sahara to enable the people of the Territory to decide their own future freely and democratically. The referendum will be organized and conducted by the United Nations, in cooperation with the OAU, during a transitional period," and in S/22464 (19 April 1991), page 10, paragraph 37, it states that "the purpose of the referendum is to enable the people of Western Sahara to choose freely between integration with Morocco and independence." 


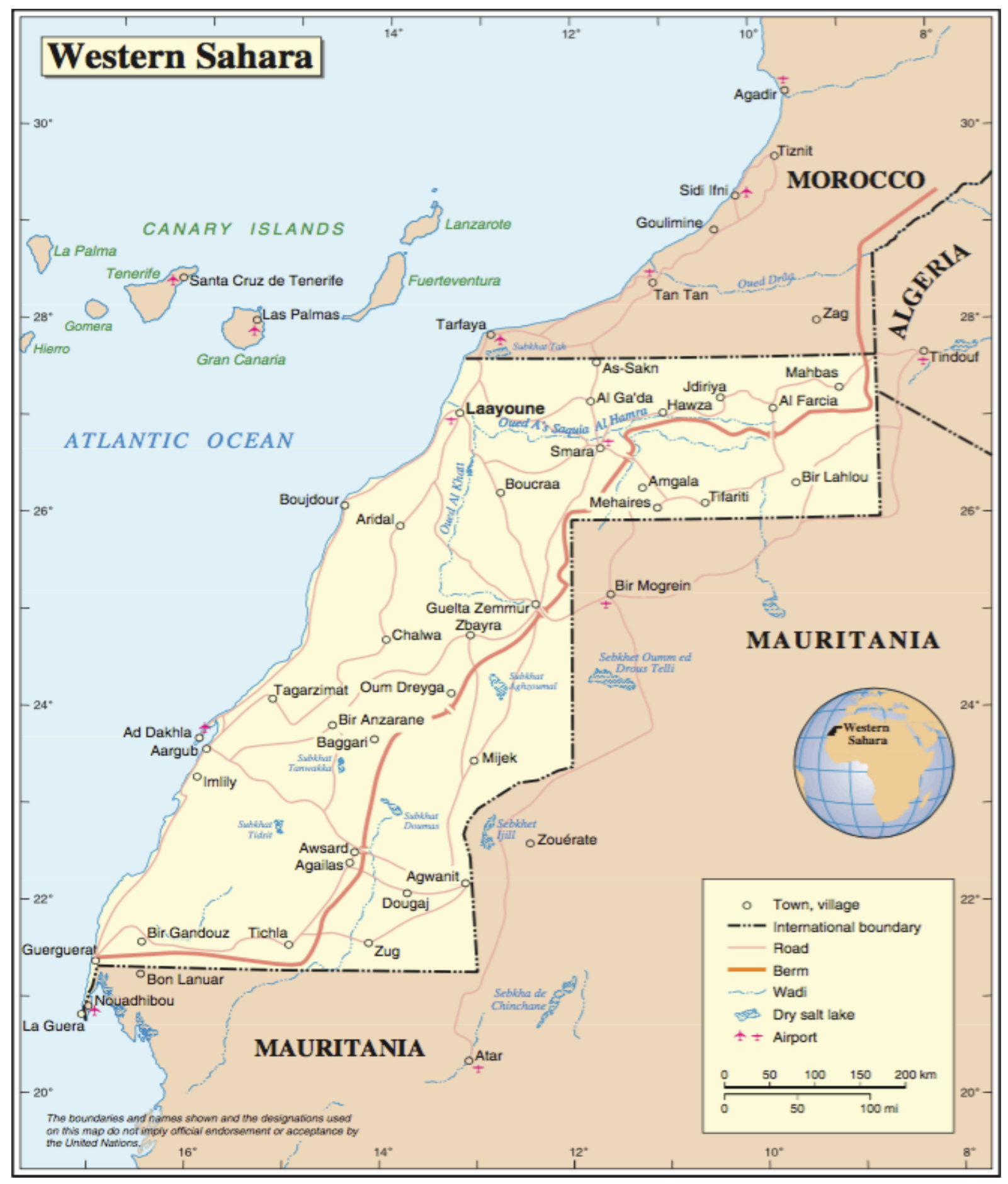

Map 1.1: The Western Sahara and the 'Sand Wall' 14

${ }^{14}$ Map by United Nations, Geospatial Information Section: ICTD Department of Field Support, Western Sahara, Map No. 3175 Rev. 4, www.un.org, accessed May 27, 2016, http://www.un.org/Depts/Cartographic/english/htmain.htm, October 2012. 
southern Morocco. ${ }^{15}$ Morocco has stated that any decision on the fate of the Western Sahara must include those Sahrawi who live in southern Morocco; these former residents migrated after Moroccan independence in 1954. On the other hand, the POLISARIO suggests that guidelines for voter identification should be based on the last Spanish census of the region conducted in 1975 . To reach any consensus on this issue, however, one has to reach beyond this question of 'eligibility' and determine where the roots of Sahrawi national identity originate. As it stands, Morocco administers the area west of the sand berm (see map 1.1) and claims full rights to all of the Western Sahara, while the POLISARIO has access only to a sliver of the land east of the sand berm as well as the "camps" outside of Tindouf currently under the protection of Algeria.

\section{Academic Significance}

There is no debate that Sahrawi nationalism exists. It is evident in the POLISARIO's pursuit of independence. There is, however, an implicit debate about the origins of their national identity. The international community has rarely been as divided over the claims to independence of a formerly colonized people. Contemporary scholarship has offered only but one solid account of the formation of Sahrawi national identity. By answering a series of subsidiary questions and ultimately the central question, this study will demonstrate the origins of Sahrawi identity. Answers to these questions will aid in understanding the origins of nationalism in post colonial states in general and the problematic stalemate in the Western Sahara in particular.

First, this study will provide a detailed account of Sahrawi identity formation and how it has developed in intensity and scope. It will evaluate the claims that Sahrawi identity has existed

\footnotetext{
${ }^{15}$ Estimates vary. Freedom House states there are 567,000 (2015) and the CIA World Fact Book projections were 570,866 (July 2013 est.). These estimates, however, include the whole of the population within the Western Sahara, with much of that demographic influx due to Moroccan immigration. These numbers do not include the Sahrawi refugee camps near Tindouf, Algeria. POLISARIO sources indicated that they harbored more than 165,000 (1980s) but the MINURSO mission had counted only about 150,000 eligible Sahrawi voters by 1998 . United Nations, "MINURSO Background," MINURSO, www.un.org/en/peacekeeping, originally accessed May 23, 2016. http://www.un.org/en/peacekeeping/missions/minurso/background.shtml,
} 
from time and has been evident before the formal colonization of the Western Sahara. Second, this study traces the development of the Sahrawi debate from an implicit to an explicit conversation. Most formal studies have treated Sahrawi national identity in a constructed sense without any substantive explanations. These works either use the term "constructed" or assume that national identity has been synthesized through external (top-down) and internal (bottom-up) influences.

Third, this study will render a clear understanding of the roots of the nationalist movement, to help forge a consensus in the international community about the validity of Sahrawi nationalism. It will outline the fundamental characteristics of Sahrawi national identity and will illustrate how the Sahrawi example correlates to the existing theoretical framework. The reader of this study will understand the different dimensions of national identity: primordial, instrumental, or constructed. This study may also narrow the distance between the conflicting parties and among interested international actors. Fourth, theoretical debates over the sources of nationalist movements will be able to use evidence from this case. To date, the case of the Sahrawi and the Western Sahara has not been analyzed along these lines. The use of these approaches demonstrates that there are varied sources that can establish the base of a nationality.

\section{Research Design}

To uncover the roots of Sahrawi national identity the theoretical framework has been structured around the three most prominent approaches to national identity: 1) primordialism, 2) instrumentalism, and 3) constructivism. These approaches offer alternative explanations to the rise of nations and nationalism. In this case, preliminary research for answers to the central question has resulted in four possible hypotheses. The four hypotheses below are derived from the three main approaches to national identity and from present scholarship. 
The first hypothesis argues that the Sahrawi are a distinct grouping of people separated from neighboring peoples by language, territory, and custom; the first two are ethnic characteristics, while the third is a cultural distinction. These distinctions set the Sahrawi apart from Moroccans and others. The POLISARIO seeks an independent state on behalf of this authentic national people. These distinctions are claimed to be socio-historically evident. This hypothesis is primarily derived from primordialism and presumes that the roots of Sahrawi identity are found deep in history.

The second hypothesis claims that the Sahrawi struggle is an extension of anticolonialism. The Sahrawi rebellion (against French, Spanish, and Mauritanian intrusion), which was evident even before formal colonization, has evolved into a neo-anti-colonialist effort against Morocco. These socio-political and anti-colonial arguments support the establishment of a sovereign republic.

The third hypothesis has determined that foreign and domestic actors appropriated Saharan identity for their own purposes: prestige, political power, and practicality. This idea suggests that these actors gave rise to a Sahrawi identity and that in the absence of such actors no Sahrawi nation would have ever developed. However, because of the length of the study, the research will end in 1973, the year that the POLISARIO was established. This hypothesis is derived from instrumentalism. A fourth hypothesis is difficult to articulate since it is based on the idea of living freely - a purely ideological argument. Not very substantive, it would tend to be incorporated by the traditional views of resistance to foreign subjugation under the first hypothesis.

These theories will aid in clarifying which hypothesis or hypotheses best explain the origins of Sahrawi national identity through a socio-historical methodology. In other words, the history of the Sahrawi will be chronologically outlined to produce a narrative of the Sahrawi, which will highlight the development of the nationalist movement from its ancient to pre- 
colonial, colonial, and post-colonial experiences. The choice for a segmented timeline is more appropriate because it would be difficult to insert topics of study within their extensive history. Thus, the project is divided as follows:

Chapter One will present the problem, provide a brief background to the conflict, and explain its importance for studies in national identity and for scholars studying the origins of nations. This section contains a summary of the theoretical framework upon which the project is based and explains how the organization. Chapter Two details the theoretical structure that supports the research, namely describing the three approaches to national identity. After clarification of the theories for national identity, the three main hypotheses are expanded (from preliminary research), to spell out the possible origins of the Sahrawi nation. Thereafter, a literature review presents what past and current scholarship has demonstrated to be the roots of the Sahrawi nation. Consequently, I will make clear the theoretical gap(s) found among Sahrawi scholarship and the weaknesses that arise from this academic oversight.

Chapter Three analyzes ancient Sahrawi origins and assumes that Sahrawi history can be traced to the original Berber inhabitants) of North Africa prior to the takeover of the Spanish fort in Santa Cruz de Mar Pequeña (located in southwestern Morocco) by the Muslim army of the Sa'adian Dynasty in 1524. It traces the Berber lineage of the Sahrawi and provides glimpses into their cohesion and group development throughout this early period. Most of the analysis will draw on historical research of the region where evidence suggests that the early origins of Sahrawi identity may be based upon an ethno-cultural distinctiveness, as the first hypothesis suggests. Finally, the first (primordial-derived) hypothesis will be thoroughly investigated as it may only illuminate a sense of group cohesion for this one period and not answer the central question. Chapter Four focuses on the pre-colonial Sahrawi experience between 1524 and 1757. I will analyze the movements of the Sanhaja Berber and their involvement in the Shar Bouba War. I will research the territorial control by key figures during the Sa'adian and Alawite Dynasties 
and the historical claims by Morocco to the territory of Western Sahara. In addition, my analysis will trace the origins of the Sahrawi in literature through library research at various Spanish State archives, including the Archivo General de la Administración in Alcalá de Henares and the Archivo Histórico Nacional (AHN) in Madrid, Spain. The analysis in this chapter will evaluate whether the second (constructivist-derived) or perhaps third (instrumentalist-derived) hypotheses are more plausible reasons for identifying a national awakening in this period.

Chapters Five and Six involve library research as well as archival documentation conducted at the Archivo Histórico Nacional (AHN) and at the Biblioteca Nacional de España (BNE) in Madrid, Spain. Chapter Five evaluates the Sahrawi experience through 1758-1859. It features the Sultans of the period and their relationship with the foreign powers and actors 'outside' their spheres of influence. It also introduces the ideas of boundaries (territorial and conceptual), literature, and 'spiritual' authority as markers of identity. In this section, I will be seeking documentation to establish the early frontiers of the Western Sahara. Chapter Six assesses the aggressive European encroachment by the Spanish and French and the reaction of the Sultans in the greater Western Sahara. This section describes the rise of several independent entities and assesses their link to the modern Sahrawi. I will search for the delineation of boundaries between the Kingdom of Morocco (under early French rule and later as an independent country) and the rest of the Saharan territory and attempt to discover the origins of Spanish and French boundary claims. Were these claims conclusions based upon group identities or other political and economic reasons? Although hypothesis two and four (ideological argument) may provide the most obvious answers to the central question in this period, all hypotheses may be applicable.

Chapter Seven examines the colonial period beginning in 1885 until the 1973. It will comment on the treaties settled by foreign powers and those agreements with the Sultan of Morocco. It will elaborate on European view of Morocco's physical boundaries and interaction with other independent entities in the region. It will highlight the abundance of autonomous 
groups that arose in the greater Western Sahara and if any of these independencies can be associated to the Sahrawi of today. The second, third and fourth hypotheses figure prominently in this last phase of the work. Finally, Chapter Eight assesses all four hypotheses for each period. The Chapter will add interviews ${ }^{16}$ with the representatives of the POLISARIO about their view about their origins. This section includes how well each hypothesis has fared and how they have answered the central question overall. A critical examination will then determine which ones answer the central question most effectively. This entire process establishes the usefulness of each theoretical approach, removes some of the weaknesses in analyzing Sahrawi national identity, and provides a better understanding of the Western Sahara conflict. Finally, this study hopes to lay a clearer, theoretical framework toward the study of any national movement today and hereafter and perhaps help break the stalemate in the Western Sahara.

\section{Delimitations}

One of the major obstacles faced in producing this study is the lack of sufficient literature on the topic of the Western Sahara. Most of the present day literature centers on the current events of the conflict evident in the CRS Reports (Migdalovitz 2006, 2008; Arieff 2011, 2012, 2013, 2014) or several UN documents dating back to 1964 (Pazzanita 2006, 421). Other topics found on the Western Sahara involve the historical facts surrounding the conflict or the legal grounds and justifications for each party to the conflict. Discussions of Sahrawi nationalism are bountiful. Yet, among the small number of scholars who do detail Sahrawi nationalism, almost nothing is written about the approach taken for the study of the problem. The historical absence of a theoretical

\footnotetext{
${ }^{16}$ These questions asked what, in their opinion, are the roots of Sahrawi identity? What is to explain the rise of the Sahrawi nation? For those who may well deny that any such group actually exists, the same questions are pertinent but asked why they believe that such a national movement exists? What or how was it created? Being the most prolific of periods for the subject of the Western Sahara, ample information among articles, books, and UN documentation will be available. Interviews conducted by author with the assistance of Mohammed Omar, translator and guide, on 25 July (Madrid) and 11 November 2013 (New York), and 28 September through 02 October 2014 (Sahrawi 'refugee' camps in Rabouni and Smara, outside Tindouf, Algeria).
} 
framework for this case presents the researcher with mapping problems. This study will offer new theoretical ground that may also be used in other case studies.

Literature on the Sahrawi is found in Arabic, English, French, and Spanish languages. The researcher is fluent in English and Spanish with a modest to a high degree of fluency in French. The literature in Spanish has proven to be valuable, but not without challenges. For example, investigating the archives in Spain includes not only deciphering the Spanish intentions of 200 to 300 years ago, but also navigating these documents solely with instructions and guides. French would be considerably more challenging at this level.

Third, as an investigator, it became evident that monetary resources to conduct interviews in Madrid, Algeria, Morocco, New York, and Washington, DC were stretched very far. The requests for interviews were many; the responses were few. In addition, the availability of many of the officials who responded did not often correspond to semester holidays or breaks in the teaching schedule. It was often difficult to schedule meetings, especially when locations were in distant countries.

Finally, the security situation has dramatically changed since the fall of Qaddafi in Libya. Tuareg rebels in Libya joined the struggle against the Qaddafi government and were able to acquire and transport modern weaponry across the region to affiliate with Tuareg MNLA rebels in Mali. The conflict in Mali has subsided for the moment. It had, however, reportedly reached SADR territory where kidnapping of foreigners and recruiting of the young in its POLISARIO camps became a concern. The threat of militant Islamists has become more pronounced with the announcement of a reinvigorated AQIM and a new group in Morocco called Sham al-Islam (Crétois and Boudarham 2014; Roggio 2016). These threats did not deter the researcher from undertaking field work, but did influence travel arrangements and navigation of the region. 


\section{Definitions of Key Terms}

I will make use of several terms in this study that have over time been interpreted in various ways and do not have clear definitions. Some of these definitions are modern concepts in the field of identity politics; a very recent subfield within international relations. Terms such as ethnicity, nation, nationality, and nationalism are all related to each other but have to be distinguished from each other to provide the reader with clarity and cohesiveness and to avoid conceptual confusion. "Ethnicity" is most commonly defined as that which pertains to or is affiliated with something 'ethnic.' Ethnic by nature is generally associated with a certain social grouping and usually described in French as an "ethnie." This grouping is defined "as a collectivity within a larger society having...[a] common ancestry, memories of a shared historical past, and a cultural focus [toward] one or more symbolic elements" (such as religious affiliation, language, tribal affiliation, or phenotypical features) (Hutchinson and Smith 1996, 6). In a separate work, Smith expands the meaning of ethnie to include the ethno-cultural characteristics or elements mentioned above as ones that are shared among these political communities $(2002,15)$. In general, these political collectivities are considered 'ethnic groups' or 'ethnic communities.'

A nation, however, is more than an ethnie. It is a socio-political collectivity, members of which, first, not only share ethnic or racial origins, but also possess those particular elements of the ethnie mentioned above (Op. cit., 15). Secondly, this collectivity should not only possess a common economic life, a geographical location, a political base, but also a sense of common identity. The key to this definition resides not in the characteristic ingredients of nation, but in the use of the phrase, 'a sense of common identity' or belonging. Walker Connor has questioned the common international relations textbook definitions of nation because of their use of these ambiguous phrases for the social collectivesense of homogeneity, sense of belonging, feeling or even group intuition. Despite this criticism, even though a sense of or feelings of oneness can ultimately lead to broad interpretations, Connor emphasizes that what matters most "is not what is 
but what people believe is" (Connor 1994, 93). Connor speaks of an intuitive conviction, which can give nations a psychological dimension, a feeling of common lineage. Third, and perhaps the most important difference between an ethnic group and nation, is that a nation has "the desire to control a territory that is thought of as the group's national homeland" (Barrington 1997, 713). These beliefs define the composition of a group, a nation.

These 'unbreakable' beliefs are not up for debate among the in-group. The value that is given to these objects of belief is transformed at the group level into shared perceptions of identity. These perceptions evolve into subjective particularities, namely those objects of belief that groups accept as realities (land, food, dress, history, language). These particularities are also recognized by those outside the in-group. There might be those among the in-group who do not recognize or simply decide to ignore these 'collective' notions. For example, Anderson has written, even among the in-group, there is no possible manner in which a member of such a socio-political entity can know "most of their fellow members," in terms of desire and goals "yet in the minds of each lives the image of their communion" (Anderson 2006, 6). Whether or not these goals are initiated by the elite, the masses, or a combination of both, the goals for their political communities largely rely on the interpretation of these objects of belief. The author agrees that there are perceived 'objective' ethnic realities. As the group becomes larger, however, and the pursuits of such an entity become more wide-ranging in scope and degree, goals diverge. The difficulty in channeling, what was once viewed as objective, to the wider segment of the population, may become interpreted differently and consequently, far more subjective.

This study agrees with Connor's evaluation of the collective self-perception and acknowledges there is a degree of subjectivity to nationhood. However, this position underscores the need for a search for the source(s) of Sahrawi national identity, whether ambiguous or not. These are the notions that have to be discovered to begin to understand the nature of the conflict. This study further acknowledges that the concept of nation is associated with some type of 
emotional attachment to those symbolic elements that are ethnic in origin: blood, language, and faith. Nation not only includes these ethnic elements but also expands them by adding domestic, political, and economic structures through the 'sense' of both common identity and "purpose: controlling the territory that members of the group believe to be theirs" (Barrington 1997, 713). A nation will not be equally associated with the term state. State implies a legally binding entity that has self-governing powers recognized by most global actors. ${ }^{17}$ It is evident that not all nations have self-governing powers. Some are subject to majority group powers, prefer a more cooperative structure with other nations, or are not recognized by global actors as legitimate political entities with which to collaborate with in formal diplomatic, economic, or socio-cultural terms. According to Connor, ethnic groups all self-differentiate themselves from other groups and are in fact already nations (Connor 1996, 40).

National Identity is a complex term that can best be defined by asking what is its elemental composition. Smith summarizes that it is "composed of a number of interrelated components-ethnic, cultural, territorial, economic, and legal-political" (Smith 1991, 15). These components fulfill the external and internal functions for groups and individuals. For instance, the territorial, economic, and legal-political dimensions serve as the external functions of groups. Groups search for 'spaces' within which to establish themselves as a cohesive society. They then seek the control of resources for their survival, and define the legal, structural framework for its individuals and lawmakers (ibid., 16). Internally, the nation serves to socialize its 'citizens' through educational standards. National identity also provides for its members, common bonds via shared myths, symbols, and values.

Finally, Smith adds that national identity "provides" for the individual a manner in which to place him/herself in the world by way of "collective personality" and "distinctive culture" (ibid., 17). By understanding the external and internal dimensions of one's shared culture, the

${ }^{17}$ Controversy exists with certain entities such as Palestine, Kosovo, Taiwan as they still have not been officially recognized by the major actors in the global arena such as China, Israel or in the case of Kosovo by Serbia. 
individual discovers or becomes 'self-aware' of these associations. If an individual or social collective perceives a tie with other individuals or collectives because of certain common elements, then it 'identifies' itself with such groups of individuals. This identification process, in turn, creates conglomerates of individuals, groups, and social collectivities. These conglomerates may eventually constitute specific nations composed of common essential traits. Smith describes this as a "process of self-definition," which is the 'key' to national identity (Smith 1991, 17). This key, the source of self-definition, pinpoints the time at which a group became self-defined, and the reasons why a group chose to self-define itself. This key is the most contentious issue among studies of nationalism. This study builds upon these definitions to determine the roots of national identity. It considers that both the internal and external dimensions of 'selfidentification' form integral parts of nationality. Thus, it is part of the ongoing conversation about national identity, and also as an important step in resolving the issue over the Western Sahara.

The major objective of this study is to trace the origins of Sahrawi nationalism through the socio-historical analysis of the Sahrawi experience. It draws insights from all of the major theoretical approaches to nationalism in order to identify phenomena that should be explored. This three-fold theoretical framework will answer the central question by using, in historical order of origin, the three approaches to the study of national identity: primordialism, instrumentalism, and constructivism. Why choose these three? Certainly there have been other methods that have tried to explain the rise of nations. Perennialism, Ethno-symbolism, and other theories have attempted to seek the origins of nations and nationalism. Socio-economic, sociocultural, and ideological reasons are all part of this discussion. However, all these other theories and reasons are best understood and can best be placed in the first three approaches mentioned. 


\section{Primordialism}

Primordialism states that the origins of national identity are to be found in the distant past (historical). It holds that nations have existed at all times of human history and that modern ethnic groups have historical continuity into the far past. Nations, according to Armstrong, began when "ethnic identification" became "widespread" and "intense" in Mesopotamia. Their different attitudes towards territory and genealogy between sedentary agricultural populations and nomad groups also became prevalent (Armstrong 1982, 8, 21, 132). Primordialism further states that national origins are an organic part of human development. National identity is found among the organic features of social existence. These cultural features are asserted to be part of the natural order and hence associated as natural 'givens.' These features are attached 'to the 'cultural givens' of social existence" such as kin, race, language, and territory (Smith 2010, 56). Finally, in more extreme versions, national origins are socio-biological extensions of the reproductive drives of individuals. (Van Den Berghe 1987)

Primordialism locates the origins of nationality in the past, through kinship and in biological heritage. The participant perceives ethnic ties collectively, as an externally given, even coercive, social bond. In Shils' study on primary groups, he found that, "modern society...is held together by an affinity of personal attachments, moral obligations in concrete contexts, professional and creative pride, individual ambition, primordial affinities and a civil sense which is low in many, high in some, and moderate in most persons" (Shils 1957, 131). He concludes that these affinities to "another member of one's kinship group is...because a certain ineffable significance is attributed to the tie of blood" (Shils, 142). Geertz confirms this idea by adding that this tie is one that "stems from the 'givens'... of social existence: immediate contiguity and kin connection...These congruities of blood, speech, custom, and so on seem to have an ineffable...coerciveness in and of themselves" (Geertz 1973, 259). Personal attachments are the "ready-made set of endowments and identifications that every individual shares with others from 
the moment of birth by the chance of the family into which he is born," which Isaacs refers to as basic group identity (Isaacs 1975, 38). Such attachments or affinities as "common territory of origin and residence, and biological connection," entail beliefs about these cultural objects that transform them into (primordial) givens (Grosby 1996, 54). The primordial givens or 'objects' of "family, the locality, and one's own people," are considered sacred because they "bear, transmit, and protect life" (Grosby, 1996, 56). This, Grosby states, is why "human beings sacrifice their lives and continue to sacrifice their lives for their own family and for their own nation" (1996, 54). Primordialism then is the approach that recognizes specific and essential objects (blood, place, and language) that bind one to another and form the group. In a sense, extending these principal items creates a nation.

Yet, the origins of the theory did not begin with Shils, Isaacs, or Geertz. The main thrust of the conceptual approach was attributed to the works of Fichte (1762-1814) and Herder (1744-1803), and their ideals of German Romanticism. They believed that the most powerful characteristic in forging a nation was language. The primordialist version of nationality was given much more weight beginning with the French revolution. The nineteenth century saw European nationalist revolts, leading to and culminating with both world wars. However, the ideological conflict of the Cold War between the principles of democratic republicanism and communism began to marginalize nationalism. American pluralist ideology sought to convert all immigrant nationalities into 'American'; communism would simply eliminate national identity altogether. The polarity of these views led to the decline of the primordialist interpretation. Decolonization in the late 1950s and 1960s brought a confluence of multinational states and instrumentalists argued that their creations were a product of power manipulation and resource consolidation by elitist groups. By the 1980s, modernists had largely discredited primordialism and absorbed instrumentalism. They developed a more eclectic approach to the study of national identity. 
Still, the end of the Cold War compelled academic scholarship to revisit primordialism to explain how the Soviet Union had crumbled into fifteen separate republics and why Yugoslavia had, in fact, several nations within its boundaries. Authors such as Smith, Kaufmann, Connor, and Armstrong have revitalized primordialism and relabeled it as ethno-symbolism or neotraditionalism. While ethno-symbolism agrees with the modernist analysis of nations as "active, purposive sociological communities embedded in particular historical epochs," it tends to reemphasize the bond that ethnic identity and community has to the "formation" and "persistence" of nations (Smith 2009, 21). Smith, the scholar who developed ethno-symbolism, states that, "although nations may be partly forged by political institutions, over the long term they require ethno-cultural resources to create a solidary community... We need to understand the oftencomplex interplay between elites and various sections of the wider population whom they may seek to mobilize in terms of symbols, myths and memories that resonate with them" (ibid.). Despite these labels, I will continue to use the term primordialism, as it tends to reinvigorate old arguments, but in a new light. There is need, therefore, to pursue Sahrawi symbols, myths, and memories, rather than to rely only on first-degree explanations for primordialism, such as language, territory, and history. As noted above, there have been no real primordialist accounts of the Sahrawi national identity question, and this perspective needs to be examined for a proper interpretation of the rise of the Sahrawi nation.

The primordial line of thinking has largely been neglected in delineating Sahrawi mobilization. POLISARIO and Sahrawi activists contend that Sahrawi identity is more essential than has been recognized. It originates from much earlier in history and can be traced through genealogy, ancient territorial affiliation, and tradition. Certain Sahrawi poets and writers-turned activists are utilizing literature to argue implicitly for a more primordial origin of Sahrawi identity. Furthermore, over the last two decades, a re-fashioning of primordialism by scholars such as Smith, Connor, Spear, and Huntington and revolutionary events such as the end of the 
Cold War have reinvigorated their arguments and warrant a renewed look at the case of the Western Sahara. Primordialism may have as much value for the case as either instrumentalism or constructivism. Despite the claims, I question the degree to which Sahrawi activism relies on primordial justification. Still, the lack of a primordialist interpretation of Sahrawi identity leaves their case incomplete and in need of a more complete review of its origins.

\section{Instrumentalism}

Within the field of political science, instrumentalism began with discussions of ethnicity rather than over national identity, and primarily as a critique to primordialism. Primordialism was criticized for being too broad an approach to nation-building due to the complexities and dynamics of political, economic, and social hybridization. In addition, the ethnic characteristics of a nation described above were being viewed as subjective features and not 'givens,' or objective cultural attributes. In the 1960s and 1970s, the debates arose in the context of how best to order society with the rise of multinational states in Africa and Asia after decolonization. Smith describes how, even in the United States, a debate had emerged between Glazer/Moynihan and Herberg over the role that ethnic identity had played in the formation of American society. ${ }^{18}$ While Herberg wrote about the creation of an American melting pot via Protestant, Catholic, and Jewish groups, Glazer and Moynihan showed how "the various ethnic groups of New York adapted to an American lifestyle" (Smith 2000, 55). This discussion fueled debate about what degree ethnic groups forge the formation of local communities, and whether these groups "should be seen as interest or pressure groups behaving instrumentally in the marketplace" (Smith 2000, $55)$.

\footnotetext{
${ }^{18}$ See Will Herberg, Protestant, Catholic, Jew: An Essay in American Religious Sociology, (University of Chicago Press: Chicago), 1955 and Nathan Glazer and Daniel Moynihan, Beyond the Melting Pot: The Negroes, Puerto Ricans, Jews, Italians, and Irish of New York City Second Edition (The MIT Press: Harvard, 1963).
} 
These issues later became prominent among academic discussions of the 'genesis of nations.' In an often referenced debate, in 1979, Brass and Robinson applied this approach in attempting to explain the formation of Pakistan. Brass wrote that the creation of nations is a type of identity formation "defined as the process of identifying the subjective meanings of a multiplicity of symbols...to give subjective and symbolic meanings to merely objective distinctions between peoples"19 (Brass 1991, 20). He believed that these elements, language, religion, kinship, and homeland, are variable, can be multiple, or irrelevant and therefore subjective. ${ }^{20}$ Brass concluded that, "nation formation is the process by which elites and counterelites within ethnic groups select aspects of the group's culture, attach new value and meaning to them, and use them as symbols to mobilize the group, to defend its interest, and to compete with other groups" $(1991,75)$. Brass disagreed with the assumption "that distinct primordial groups in society are sufficient to predict the future development of ethnic communities or nations" and may be of no use "in predicting either the development or the form of ethnic movements" (1991, 72-73). Robinson generally agreed with Brass' view, but in reverse, by arguing that Muslim elites in north India and the Bengal region drew from select cultural distinctions and the ideology of the umma by applying to them symbolic meaning in order to safeguard their Islamic heritage, resulting in the independent state of Pakistan (Smith 2000, 22).

Instrumentalists also argue that the elements noted above are given non-rational or even irrational meanings. Thus, instrumentalists seek more rational explanations to nationalist mobilization. They seek the roots of national identity from its political and economic environment. Ethnic leaders and elites will use "their cultural groups as sites of mass mobilization and as constituencies in their competition for power and resources" (Smith 2010, 59). Hence,

\footnotetext{
19 The full quote includes, "and of striving to achieve multi-symbol congruence among a group of people defined initially by one or more central symbols, whether these symbols are ethnic attributes or loyalty to a particular state," but has been purposely omitted for reasons of space. Brass 1991, 20.

${ }^{20}$ For instance, an individual can speak more than one language or convert from one faith to another.
} 
"the political process determines the character of ethnicity and its role in the polity" (Robertson 1997, 267). This led to Brass' conclusion that "a nation therefore is an ethnic community politicized" (Brass 1991, 20). Furthermore, this politicization follows Barrington's definition associating a nation with its belief in the right to territorial self-determination (Barrington 1997, 73). In brief, instrumentalism treats national identity primarily as an ad hoc element of political strategy, used as a resource for interest groups or one created "for elites in competition" for achieving secondary goals, for instance, an increase in political power and economic advantage (Brass 1991, 15). In this sense, Brass regards nationality, in large part, as the study of politically induced cultural change (ibid., 75). Breuilly expands on this view by declaring that nationalism can only be understood as a 'form of politics,' "as the expression of national consciousness, as a political doctrine elaborated by intellectuals" (Breuilly 1994, 1).

Instrumentalists critique primordialism for its objectification of cultural attributes for group identification, and in contrast, interpret them to be more subjective than objective in nature. Thus, instrumentalists will seek more rational or objective criteria for explaining the rise of nations. In this case, instrumentalism, which has been only informally used, suffers from a lack of in-depth application, or has been poorly articulated in explaining Sahrawi mobilization. For example, Moroccan authorities often state that the POLISARIO has manufactured Sahrawi national identity out of whole cloth and fully reject the notion of a Sahrawi nation. At the other extreme, it is doubtful that all Sahrawi still continue to regard POLISARIO leaders as their chief spokesmen for independence. Even if these claims were true, accepting the argument that such an elite group (or other such interest groups) has 'managed' the movement (for its own political reasons) may not alone answer the central question. Instrumentalist arguments are neither clear, nor fully explored. 


\section{Constructivism}

Constructivism rejects that nationality or even ethnicity is the essential human condition but rather approaches the study of nationalities as products of human social interaction, that is, socialization and historical forces. Smith writes that nations are viewed as a combination of cultural artifacts and social constructs. Elites fashion these artifacts by representing the past, upholding the importance of identity, and promoting them through cultural media and social

ritual, a method of social engineering (Smith in 2000, 52 and 2001, 79). This socialization is realized by way of political processes, normally labeled as ethnopolitics. However, ethnopolitics can vary in degree and depth because of "the structure of societies, and the political and economic institutions embedded in them, which limit and empower individual human agents who act to create ethnopolitics" (Robertson 1997, 268). Consequently, constructivism is regarded as the "conjunction of [these] social processes and political action that creates opportunities for leaders to use nationalism and the incentives for followers to support nationalism" (Robertson 1997, 274). Ultimately then, one of the primary tenets of social constructivism is the assumption "that nationalism created and continues to create nations, rather than the opposite" (Smith 2000, 52.)

Alexander Wendt introduced constructivism in the field of international relations and advocated that rather than explaining world politics through its epistemological assumptions, one should understand it through ontological eyes by asking, "what is it made up of or how is it structured" (Wendt 1999, 370). Wendt summarized his "ontology of international life...[as] 'social' in the sense that it is through ideas that states ultimately relate to one another, and 'constructionist' in the sense that these ideas help define who and what states are" (Wendt 1999, 372). In the subfield of national identity, his approach has been extended to the question of nations. Although modern scholarship has largely been credited for elaborating and articulating the constructivist approach, the origins of constructivism can be traced to the works of Herder, Renan, and Max Weber. Though Herder was previously mentioned when describing 
primordialism, Ergang explains that he also saw "nationality as a product of nature and its growth as regulated by the laws of nature," where nature "was the great architect who planned and constructed the group" (Ergang 1966, 95). Herder believed that certain social (as opposed to natural) factors (education, physical environment, intermarriage, and tradition) influenced the national soul (Ergang, 112). Weber wrote that "naked prestige of "power"" transforms direct and material imperialist and ideological interests into the idea of the nation (Gerth and Mills 1946, 172). Although Weber mentions that language is the primary cultural element in the formation of national sentiment, he states that it is not a sufficient criterion for the creation of a nation. Instead, Weber treats nation as those "groups of men" exacting "a specific sentiment of solidarity in the face of other groups (ibid.). National identity may be connected with ethnic elements but it may also, "above all, "be linked to the memories of a common political destiny" (ibid., 173). Here then, one finds early writings attributing national identity to the product of both primordial (linguistic and natural) and instrumental (interests and power) elements.

Thus, constructivism can be viewed as a hybrid approach to the study of national identity because it seeks its origins in both objective and subjective features. Renan had stated that a nation consisted on the one hand of, "the possession in common of a rich legacy of memories; the other [one] is the actual consent, the desire to live together, the will to continue to value the heritage which all hold in common"21 (Conference at the Sorbonne, March 11, 1882). Scholars such as Hobsbawm (in his later writings) and Robertson have concluded that this approach is a fusion of the primordial and instrumental theories of national identity. Hobsbawm wrote that nations are "constructed essentially from above" but they "cannot be understood" without being

\footnotetext{
${ }^{21}$ Ernest Renan, "Qu'est-ce qu'Une Nation?," Conférence Fait en Sorbonne, Le 11 Mars 1882, Deuxième Edition, (Paris: Calmann Levy, 1882), 23. "L'une est la possession en commun d'un riche legs de souvenirs; l'autre est le consentement actuel, le désir de vivre ensemble, la volonté de continuer à faire valoir l'héritage qu'on a reçu indivis." Taken from John Hutchinson and Anthony D. Smith, Nationalism, (New York: Oxford University Press, 1994), 17, trans. Ida Mae Snyder. Original English translation used 'remembrances' instead of memories. Here, I will use memories as an easier, more palatable term. Memories are understood as an objective (or rational) feature while the will or consent to live together is a group characteristic that is dependent on subjective and non-- or irrational ones.
} 
"analyzed from below" (Hobsbawm 1990, 10). Robertson concurs, arguing that national mobilization is a "combination of a top-down political movement with the process of bottom-up social mobility"22 (Robertson 1997, 274). Anderson, in his most quoted of phrases, declared that a nation is imagined as a limited (because it has finite boundaries) sovereign (born in the Age of Enlightenment and revolution) community (conceived as a deep, horizontal comradeship): "it is an imagined political community" $(1983,17,19)$. According to constructivists, the roots of national identity lie with the instruments of social control and they emphasize that nations are culturally engineered, constructed from 'invented traditions' (Hobsbawm) or are 'imagined communities' (Anderson). In general, then, constructivists search for such 'inventions' among the social instruments of 'national' education (and the retelling of its national history), in public ceremonies, monuments, and speeches, and religious iconography (Hobsbawm and Ranger 1983).

If constructivism is a fusion of primordialism and instrumentalism, why then pursue any other framework for seeking the origins of Sahrawi national identity? Preliminary research has found that concentration on constructivism, as defined above, used often to explain the origins of Sahrawi national identity, has marginalized, with heavy critique, the other two approaches to national identity. Scholarship of the Western Sahara problem is dominated by this very contemporary view. It is rooted in the works of Kedourie, Gellner, Anderson, and Eriksen. If such a theoretical merger is sufficient, why have bottom-up and top-down examples of this fusion not been more readily evident in the literature? Even though there are several competing authors within the constructivist line of thinking, many only refer to this notion via popular constructivist terminology without adequately elaborating these "traditions," "imaginations," or social constructions. Sahrawi national identity and its origins, if it is rooted upon such social constructions, is certainly in need of a clearer understanding of these indications of synthesis.

\footnotetext{
${ }^{22}$ Robertson is actually describing nationalism with this quote.
} 
In summary, it is necessary to employ all these approaches to understand the origins of Sahrawi national identity. Since most explanations for the rise of the Sahrawi nation rely on constructivist ideas, it is apparent that such predominance is a weakness in the literature on the subject of the Western Sahara. Croucher wrote, at the beginning of her review of the ethnic conglomeration of Miami, that she would use all of the available tools in order to explain the "origins and processes that construct competing narratives and show how they change over time" $(1997,21)$. I will follow this same route, not because these explanatory tools are available, but because academic study concerning the origins of Sahrawi national identity suffers from an inherently one-sided theoretical approach. Although constructivist notions of national identity will be applied, instrumentalist and 'rekindled' primordialist explanations are also employed to make the Sahrawi socio-cultural and geo-political past and present more clear. Utilizing all three approaches will explain when Sahrawi national identity originated and equip us with a better understanding of the Sahrawi and their pursuit of independence for the Western Sahara. 


\section{LITERATURE REVIEW}

This chapter will evaluate sources that deal first with the history of the region and its early inhabitants. This section will include subheadings that deal with ancient, medieval, and the colonial period of the region touching upon how these sources viewed the population in the northwest Sahara. Next, it will review the literature that outlines how scholars view the Sahrawi as a nation. This includes the varying interpretations on how the Sahrawi have come to be, in terms of achieving a distinct national identity. A smaller subsection will attempt to divide such interpretations by the various scholars into the three approaches of national identity: primordialism, instrumentalism, and constructivism. The study will not include other material that involves the current political situation that speaks of current foreign (i.e., UN, AU, U.S., and France) or domestic (Morocco, Polisario) policies taken by the various actors on the Western Sahara unless it is directly related to the study.

One of the weaknesses of Sahrawi scholarship has been the surprisingly small number of studies surrounding the problem, especially from American scholars. Most scholars that write about the Maghreb will not cross Arab political sensitivities. The Arab world, for the most part, has treated its minorities, not as co-equals, but as second-class citizens. Also, much of the academic discussion about the Arab world has been dwarfed by the Israeli-Palestinian issue and the surrounding security concerns stemming from the conflict for its neighbors. The recent and current Iraqi Wars, the present civil conflicts in Syria, Yemen, and Libya dominate Near East news media and scholarly research. Moreover, these conflicts, largely as a result of the 2011 Arab uprisings across the Middle East and North Africa have diverted attention from the Sahrawi problem and channeled it toward the domestic and political group divisions among Arab states. Despite the marginalization of the Western Sahara issue and the plight of the Sahrawi, these conflicts across the Middle East have highlighted the ethnic, religious, and racial divisions that plague the region. These groupings are present in Syria among Alawi, Kurd, Sunni, and even 
Christian faiths; in Libya as territorial and tribal divisions among the areas of the Fezzan, Cyrenaica, Tripolitania and the Tuaregs; and in Algeria between Kabylie (Berber) and Arab. In addition, as this study will show, Arab predominance in northwest North Africa is also subject to ethno-linguistic divides between Arab, Berber, and Sahrawi ${ }^{23}$. However, the mere mention of another possible 'nation' arising within Morocco's historical territory is contrary to Moroccan mentality.

The subject of the Western Sahara is one that has not captivated many scholars for several reasons. Academic study about the region is weak; acquiring previous studies is challenging. In fact, North Africa as a region, with the Sahara to its south and the Sahel even further to the south, creates a geographic barrier that divides the 'black' or sub-Saharan Africa and its north. This divide not only separates Africa socio-culturally, but also geo-politically, and leaves North Africa desolate, minimally populated, insignificant for study. The same can be said of northwest Africa the location of Western Sahara. Moreover, there has been very little archaeological investigation due to the conflict between Morocco and the POLISARIO and bureaucratic impediments for scientific study by both Algeria and Morocco. The inhospitable and barren nature of the land, not just in Western Sahara, but also further inland, across the whole of the Sahara, has stifled geo-political relevance for the region. ${ }^{24}$ There is very little protection for military basing (extreme temperature fluctuations and sandstorms can quickly destroy armament and weaponry. Camouflage is difficult. Accommodating soldiers in an inhospitable land is difficult). In addition, this area has no significant value since it is neither (at the moment) rich in valuable resources nor is it ideal for long-term investments of any kind-commercial, agricultural, or military.

\footnotetext{
${ }^{23}$ Sahrawi is actually translated as Saharan in Arabic

${ }^{24}$ An exception would be entry and maintenance of the Straits of Gibraltar, which is an important waterway for navigation and commerce.
} 
The conflict between Morocco and the POLISARIO has become so polarized that it is increasingly difficult to conduct an objective investigation. The Kingdom of Morocco is opposed to any 'homeland' for the Sahrawi because it does believe that an argument exists for such an entity. Moreover, it characterizes those who oppose to the Kingdom and support the POLISARIO as 'separatists' rather than as nationalists. Morocco and the U.S. Department of State characterize the conflict as a political problem rather than an ethno-nationalist issue ${ }^{25}$. On the other hand, the POLISARIO claims that the Western Sahara is the rightful territory of the 'Sahrawi' and therefore continues to struggle for its independence. A small amount of compromise between the two parties has resulted in a stalemate that has lasted at least twenty-five years. Disagreement arises from the identification of a 'true' Sahrawi. Thus, most of the literature either supports one side or the other. Academic study that advances a middle ground is difficult to find unless it is documenting plans for the long awaited (and possibly never-to-be determined) Western Sahara referendum.

The conflict has exacerbated Western Saharan isolation, limiting thorough studies of any kind after Spanish colonization. First, the POLISARIO insists there will be no oil exploration off the coast of the Western Sahara (or inland) pending resolution of the territory. Second, the Kingdom of Morocco has placed obstacles, both physical (Kingdom of Morocco's length-wide sand berm) and procedural (requests to visit for research bog down into lengthy periods of 'review' $)^{26}$. Foreign visitor movements require 'monitoring.' These impediments have dissuaded

\footnotetext{
${ }^{25}$ Based on discussions with the U.S. Deputy Chief of Mission and other local nationals working inside the U.S. Embassy in Rabat during my time as a U.S. State Department political intern in October-December of 2012.

${ }^{26}$ The author initially requested a visit to the Kingdom of Morocco in order to conduct research on the topic of Sahrawi
national identity 02 January 2014. This request was sent twice. A reply arrived 20 January 2014. Email communication
continued through February, including notification that the Ministry of Foreign Affairs (MOFA) and Cooperation
would provide the author with an itinerary that would include a trip to the Western Sahara and interviews with NGOs,
academics, and ministers of government. However, via email on 24 March 2014, the Deputy Delegate to H.M. M'barka
Bouaida, Khaoula El-Kasmi, stated that a few formalities were needed in order to have the research request approved.
These formalities included a formal request to the Moroccan Embassy in Washington, DC, thesis statement, and a letter
of reference from the university. All documents were sent via email two days later. A reply, on June 6, stated that "a
request to establish a program of your visit to Morocco has been sent to our Ministry and we are waiting for their reply"
} 
scholars and investigative journalists alike. ${ }^{27}$ Literature written about Western Sahara includes such topics as the women in the SADR camps, the refugee status of the Sahrawi, the structure of the SADR, the history of the region, the issue over the referendum, and of course, since 1975, descriptions of the most recent events in the conflict. Yet, despite these accounts, English language study of the situation has been overtaken by other, more prominent issues in the Middle East or on the continent of Africa ${ }^{28}$. A third problem with study of the conflict over Western Sahara has been the low level of interest among American scholars compared to European academic research. European scholarship tends to be predominately written in Spanish or French, leaving the unilingual American or British researcher at a disadvantage. There is literature about the subject in Arabic but even the author cannot identify how much has been written because of his inadequate and very basic understanding of Arabic.

Yet, despite the limitations to the study of the subject, the author has uncovered an abundance of (hard-to-find) literature. Although there have been significant writings about Sahrawi nationalism and the origins of their national identity, this kind of information will occupy less than a half a bookcase shelf in any library. English-only researchers need not be disappointed at the relatively low numbers of books on the Sahrawi or the Western Sahara. This dissertation will provide an impetus to widening and enhancing not only the study of the Sahrawi, but also other such groups, who identify themselves as autonomous nationalities. In fact, the author feels that there is much more information about the Western Sahara and Sahrawi national

\footnotetext{
(However, this reply was prompted by another email sent to the MOFA two days prior asking for one last opportunity for a research visit). Today, 26 August 2016, there has still been no reply.

${ }^{27}$ In fact, the author has been dissuaded from applying for certain fellowships because of the politically sensitive nature of the conflict.

${ }^{28}$ A recent Amazon search of new, in stock, twenty-first century titles in English produced 262 books on the 'Arab Spring,' while the same criteria applied for the Western Sahara that began forty years ago resulted in only 107 books. Another comparison can be made at the Library of Congress, where an online catalog search with the words 'Arab Spring' and 'Western Sahara' as a phrase gave 137 for the former and 119 for the latter. 40 years of conflict has been surpassed by the study of the five-year-old 'Arab Spring.'
} 
identity, which can be found through un-translated Arabic sources and may be in other untapped African or European sources. Below, I will introduce several of the most important works about Sahrawi national identity and classify each under one of the three main approaches to nationalism.

\section{Theoretical Research}

Not only has the terminological use of "nation" evolved, but the methodological approaches to the study of nationalism have also changed over time. These approaches have created substantially more ideas as to how nationalism is interpreted. These approaches can be categorized into three main branches: 1) primordialism, 2) instrumentalism, and 3) constructivism. This triangular approach is not one that is readily accepted among academic scholars. For example, Phillip Khoury, has written that the "[u]nderstandings of a nation generally adhere to one of two schools: 'primordialist' and 'modernist'" $(2011,13)$. In fact, he further states that, "the primordialist approach is little adhered to anymore in scholarship or intellectual circles" (ibid., 13). Khoury, in his comparison of Palestinian and Sahrawi nationalism states that the "modernist, or 'constructivist' approach...is both accepted and important for contextualizing the UN's legitimation of nationalisms" (ibid., 13). He believes that these types of theories are 'concurrent' with 'understanding nationalism as a modern political project in which nations are constructed, not given a priori." (ibid.). For example, he prefers to follow the line of thinking by Ernest Renan in describing nation building as a 'spiritual' project rather than one based on common features such as race, language, religion, or even geography (ibid.). For the most part, this statement is true.

However, despite Khoury's interpretation of Anthony Smith's reformulation of primordialism into a more constructivist approach, academic scholarship usually slights the beliefs of those who are actually in the process of establishing their national identity. Those 
members, who compose a 'polis' or political community, rarely, if ever, question how they have 'become' a nation, how their claims to a national identity were "based upon certain shared ethnic and cultural characteristics" (ibid., 14). Instead, these groups understand that their origins are tied to features that they believe are inviolable, have been eternally theirs, and reach deep in the past - a set known, perhaps not to others (in academia), but made absolute by observation unto them. Thus, despite Khoury's misgivings about primordialism, it still clarifies a very important component of national identity. It is imperative to include these primordial works in such a literature review. Khoury does provide for a very good discussion of the modernist (constructivist) ‘conception' of statehood of Sahrawi and Moroccan identity.

One interesting West Saharan-Moroccan issue that exemplifies the primordialconstructivist debate concerns the current stalemate over who is a Sahrawi. Perhaps the biggest matter of contention is deciding who is eligible for voting in this yet-to-be determined referendum. For instance, the Kingdom of Morocco has supported a policy of jus sanguinis (right of blood) in addition to "members of Sahrawi tribes with links to the territory (of the Western Sahara)" (Jensen 2012, 1). According to the POLISARIO, eligibility should be limited to jus soli (right of the soil) and closely parallel the Spanish national census of 1974. In 1991, after several broken cease-fires and informal talks, Morocco and the POLISARIO approved a UN settlement plan. At this time, an informal cease-fire has become permanent and both sides have sought a non-violent resolution. The POLISARIO, in a surprise move meant to isolate and pressure Morocco, accepted James Baker's 2003 Peace Plan, but Morocco rejected it. ${ }^{29}$ Thereafter, consensus to resolve the problem has been difficult. Consequently, Morocco has brought forth its own initiative of autonomy for the Western Sahara. ${ }^{30}$

\footnotetext{
${ }^{29}$ Peace Plan for Self-Determination of the People of Western Sahara, May 23 2003. Pazzanita, s.v., "Chronology,” xl.

${ }^{30}$ This initiative brought forth by the Kingdom of Morocco as the Autonomy Plan for the Western Sahara was presented to the UN in April 2007.
} 
The Primordial Literature

The works classified under this heading will be those who have theorized or through the empirical research, either explicitly or implicitly, that Sahrawi national identity is found through primordial arguments. To reiterate, primordialism states that national identity is rooted or can be found in the past, through kinship and biological heritage. Members perceive to have an ethnic tie, either from others (externally) or from the in-group (coercively), and in this sense form a distinct group-even a distinct nation. These affective ties are generated from ethnic characteristics, such as language (Johann Herder) and territory. Although the post-modern worldview would argue that the socio-political environment and other interests have created these nationalities, Anthony D. Smith emphasizes that these groups still necessitate ethno-cultural assets to create unitary communities.

In Shil's study on primary groups, he found that, "modern society...is held together by an affinity of personal attachments, moral obligations in concrete contexts, professional and creative pride, individual ambition, primordial affinities and a civil sense which is low in many, high in some, and moderate in most persons" $(1957,131)$. He concludes that these primordial affinities or attachments to "another member of one's kinship group is...because [of] a certain ineffable significance is attributed to the tie of blood" (Shils 1957, 142). Clifford Geertz attributes this tie to one that "stems from the 'givens'... of social existence: immediate contiguity and kin connection...These congruities of blood, speech, custom, and so on seem to have an ineffable...coerciveness in and of themselves" (Geertz 1973, 259). The primordial givens or 'objects' of "family, the locality, and one's own people," are considered sacred because they "bear, transmit, and protect life" (Grosby, 1996, 56). This is one of the reasons why Steven Grosby states, "human beings sacrifice their lives and continue to sacrifice their lives for their own family and for their own nation" $(1996,54)$. These essential objects — "common territory of origin and residence, and biological connection" - entail beliefs about these objects that 
transform them into (primordial) attachments (Grosby 1996, 54)]. These attachments or ties are the "ready-made set of endowments and identifications that every individual shares with others from the moment of birth by the chance of the family into which he is born" that Harold Isaacs calls basic group identity (Isaacs 1975, 38). Primordialism then is that concept that qualifies specific and essential objects (birth, place, language) that bind one to another-forming the group and, in this sense, extending these principal items to a nation.

Another form of primordialism, 'soft primordialism,' advanced by Anthony D. Smith, suggests that in order to understand ethnicity, one must "pay more attention to the subjective elements [ethnic memories, values, symbols, myths and traditions] in ethnic survival" (Smith 1999, 130). Moreover, these ethno-symbols "unite and inspire the members of an ethnic community over several generations" (Smith 1999, 130). Yet, such a formulation of an ethnic nation is not natural but ever changing. This leads to a subset of primordialism described as "perennialism." This modified primordial view holds that those groups that have been able to 'cultivate' a mythic election via these national symbols "succeed" in "prolonging the specific collective life of their members over many generations" (Smith 1999, 130).

Within nomadic groups, the primary attachment to the leading clans or families, even after they became sedentary, would be retained through 'genealogical myth' (Armstrong 1982, 51). The bonds of clan or family and territory via symbols (nostalgia, myth) were reinforced by "ancient polities and ecclesiastical" structures, which defined ethnic boundaries and thereby left an indelible mark on $a$ (national) identity consciousness. John Armstrong explains that among sedentary populations, nostalgia became a "strong symbolic device" that transmitted attitudes, which were directed toward territorial attachments $(1982,50-51)$. These ethnic formulations transcend time, extend over centuries or even millennia (continuous perennialism) but may fluctuate with importance and dominance or perhaps even disappear altogether (recurrent 
perennialism ${ }^{31}$ ) but the "phenomenon itself is universal" (Smith 2000, 34-35). There are certain Sahrawi symbols or objects, such as poetry, ancient historical stories or myths, and ties to old lineages promote the ethnic nationalist argument. In one sense, the question of Western Sahara identity suffers from an almost complete disregard of the primordialist application because of its decline in academia. Primordialism had been resurrected due to the past geo-political environment but continues to wane in this new century. In another sense, primordialism has not been relevant among North African scholars because of the biases in French and Arab scholarship, which take the side of Morocco and reflect their political and Arab nationalistic sensitivities. Those authors who have supported the Sahrawi right to independence usually have writings grounded in legalistic, political, and human rights terms.

Only a certain few scholars, for instance Faten Aggad and Pierre du Toit Botha, have recorded some sort of perennial affinity, a subset of primordialism, within the Sahrawi narrative by pointing to territorial treaties ${ }^{32}$ that linked Western Saharan lands, and legitimized its sovereignty ${ }^{33}$. Still, few connections have been made about Sahrawi early history. The ancient history of a nation should indicate that the group in question had a certain beginning and therefore could be recounted from sources found through archaeological excavation and exploration. This is quite certain with groups such as the Assyrian, Sumerian, ancient Egyptian because of discoveries in art, script, and architecture. Others, for example, Greek, Roman, Inca, Berber, and Mongol also have very well documented sources, and more continue to be discovered in the

\footnotetext{
${ }^{31}$ Continuous perennialism sees nations in earnest existing for centuries, if not millennia, even if they do not exist under the same name or ruler.

32 Treaties signed in 1727,1799 , and 1885 by Spain for the specific purpose of protecting these Saharan areas or presides that had been historically claimed by Spain.

${ }^{33}$ Such arguments may lead to recurrent perennialism, a more historically verifiable subset of perennialism that sees nationalism as a dynamic political force that changes constantly to serve varying needs for ethnic groups. Perennialism explains that nations and nationalism survive because they have always existed as a means to protect ethnic groups but it is not an organic process. Smith and others seem to attach ethnic identity with the historical survival of nations but nationalism is merely an expression of short-term goals for a certain generation of ethnic and social forces.
} 
twenty-first century. However, there are several that, according to some scholars, transcend antiquity and are presented as nations that have had a perennial existence. The Jews are presented as one of the best examples of a perennial nation. Other such nations include northern European and Scandinavian groups, namely, the Anglo-Saxons, German, and Rus. It is in this latter category that some pro-independence supporters for the Western Sahara claim that the Sahrawi nation should be viewed because of its 'ties' to the Sanhaja Berber. The origins of the Sanhaja Berber date back to the Bafour. Still, much of this history is disputed because direct evidence has not been thoroughly examined to prove these links. The claim of a continuous or perennial national identity for the Sahrawi is based on certain assumptions and circumstantial hypotheses. Thus, the following sources for Sahrawi national identity are placed in the context of a still to be determined and verified Saharan history.

\section{Sahrawi History}

The ancient history of northwest Africa has not been studied as thoroughly as perhaps other areas across the globe because of the nature of the Sahara Desert. In fact, there is still much to be explored and examined. The attacks of September 11 and afterward have placed limitations on tourists traveling for pleasure as well as for researchers conducting field work. Currently, the inhospitable landscape of the Sahara does not lend itself to long-term research and the threat to known foreigners discourages many from attempting research even under the auspices of government protection. ${ }^{34}$ For instance, the only country in the politically-defined region of the

\footnotetext{
${ }^{34}$ While the author of this work was conducting interviews with the leaders and elites of the Sahrawi in the camps near Tindouf, Algeria, I recall questioning my interpreter/guide during my time in 'Rabouni Camp' about an incident in October 2011 of three foreign aid workers who were abducted from their camps. Mohammed Omar, my guide, responded and stated that those three individuals (2 Spaniards and an Italian), who were taken by the Movement for Unity and Jihad in West Africa (MUJAO), an AQIM splinter group, actually stayed in the same compound as I was being lodged. It came as a complete shock when he informed me only days after I had arrived. Despite my nervous apprehension, the feeling of utter isolation, and the decision to 'think' through how to escape the room I was given, in case I needed to flee those first few days, I remained calm and felt at ease by the following week. Still, these types of incidents are an inescapable part of risk and reality involved in choosing to investigate this topic. The trio was held in Mali and released July 2012.
} 
Maghreb (excluding Egypt) that does not have a travel warning published by the U.S. State Department is Morocco. ${ }^{35}$ In addition, Americans wishing to investigate sources of information about the history of the northwestern Sahara will largely find most of the scholarly literature, specifically of the Western Sahara, in European depositories and libraries, and only in certain languages such as French, Arabic, or Spanish. The following should inform and guide the reader to some of these sources.

The search for the origins of Sahrawi national identity led the author to sources that did not actually focus on the Sahrawi. Sources that cover the ancient history of the region or trace the Sahrawi to a period in antiquity are scarce. These sources were used to explore arguments derived from primordialism - that these ancient groups are associated to the Sahrawi. Many of these sources of information were difficult to find and obscure. For information deep in antiquity, the author relied on sources that were primarily about the history of northwest Africa. For example, Michael Brent and Elizabeth Fentress (1997) document the origins of civilization in North African but do not associate the Bafour or even the Berber to later groups. However, they wrote a history primarily of the Berbers and not about the Sahrawi. Encyclopedic sources were utilized for documentation of the group but these were primarily historical in scope. Other authors briefly commented about the Bafour such as János Besenyo (2009), Pierre Bonte (1981), Geneviève Désiré-Vuillemin (1962), Tara Duebel (2010), Zahra Hasnaui (2007), Pasqual del Riquelme (1991), and James L. Webb (1995). Although the majority viewed them as ancient inhabitants of northwest Africa, none directly linked the Bafour to the Sahrawi. In fact, Bonte, Pasqual del Riqulme and Webb place the Bafour in the sixteenth and seventeenth century. Lucas (1931) writes of the Bafour extensively but mainly to draw out their ancient and mixed ethnic composition.

\footnotetext{
${ }^{35}$ There are travel warnings for all or parts of the following countries: Libya, Tunisia, Algeria, Mali, and Mauritania. U.S. Department of State-Bureau of Consular Affairs, "U.S. Passports \& International Travel," travel.state.gov, accessed June 07, 2016, https://travel.state.gov/content/passports/en/alertswarnings.html .
} 
Several Spanish authors detail the ancient history of the region as one that has been contested among the Berber and Arab dynasties with no concrete sense of limiting frontiers or agreements delimiting territory. Enrique D'Almonte describes the medieval period of the region as one of conquest, expulsion, retreat, and incessant movement of tribes (nomadism). For example, he describes in brief that the lineage of the Oulad Delim (one of the oldest tribes of the Western Sahara) can be traced back to those who were expelled by the followers of the Mahdi (divinely guided one) and 'Abd al-Mu'min ibn 'Ali (founder of the Almohad Dynasty), and fled to the Sahara. Those refugees included Arabs and Berbers who were marked as partisans of the dethroned Almoravid Dynasty. These people mixed, settled, formed the ed-Dala tribe, and became what is now the Oulad Delim tribe (sons of the delinquents). Chronicling the history of an area long mired in the ebb and flow of tribal affiliation and fragmentation $(1914,155)$. D'Almonte subsequently writes of another instance of historical significance in 1590-1591: an expedition led by Moulay Ahmad al-Mansur to take Timbuktu. "This warlike expedition, that momentarily was able to attract the attention of the Saharan tribes, left little permanent mark among those indomitable nomads, who promptly returned to their mutual and regular raids and quarrels" $^{\prime 36}$ (D’Almonte 1914, 156). Here, he briefly mentions the short-lived union of Saharan tribes for the purposes of defense, only to later continue their nomadic and "kleptomaniac" lifestyle (ibid., 155).

Abadallah Laroui (2001), Jamil Abun-Nasr (1971), and Charles-André Julien (1970) all document early periods of North Africa but do not place the Sahrawi in any historical context and only served to document early groups in the general region of northwest Africa. Those who did make mention of specific groups that provided for some connection to Sahrawi lineage were obscure and relatively unknown in American academic circles. E.G. Bullard (2001), Steven

\footnotetext{
${ }^{36}$ From the Spanish and translated by the author: "Esta expedición guerrera, que momentáneamente pudo atraer la atención de las tribus saháricas, no dejó huella permanente entre aquellos indómitos nómadas, que volvieron prontamente á sus habituales y mutuas razzias y rencillas," in Enrique D’Almonte, Ensayo de una Breve Descripción del Sáhara Español, Boletín de La Real Sociedad Geográfica: Madrid, 1914.
} 
Danver (2014), Angelo Ghirelli (1942), William Smith (1854), Soler Subils (2007), and A. J. Lucas (1931) are all contributors to northwestern Africa or greater western Saharan history. Despite Laroui, Abun-Nasr, and Julien's volumes of methodical research of the Maghrib, they do not make connections to the Sahrawi. However, they do provide important contextualization of the early period of the Maghrib.

\section{Instrumentalism}

Critics of primordial objectification (and perennialism) counter that these ethnic attachments to objects or ideas are not rational and do not explain why people become attached to certain groups and not others (Smith 2001, 54). It fails to explain why nationalist fervor fluctuates at certain instances and why these core essentials-blood, kin, symbols or myth-produce mass mobilization. To answer some of these questions, instrumentalist arguments were provided primarily to shed light on the intensity and scope of national mobilization. Not only do primordialists incorrectly treat cultural attributes as objective criteria for explaining national consciousness but they are also given irrational explanations to nationalist mobilization. Instrumentalism is an approach that focuses on rational explanations to nationalist mobilization. Thus, considerations are presented that describe how ideas, artifacts or objects—such as land and poetry-history, and resources are manipulated by past and current interest groups either unknowingly or with direct intent. These instrumentalist considerations touch on geopolitical consequences, socio-institutional practicality, and the economic feasibility of such an (independent or nationalist) enterprise.

Instrumentalism views nationalism as a "form of political behavior" (Breuilly, 1994, 1). It is "a political doctrine elaborated by intellectuals" or "a process created in the dynamics of elite competition within the boundaries determined by political and economic realities" (Breuilly 1994, 1; Brass 1991, 16). Ethnic leaders and elites will use "their cultural groups as sites of mass 
mobilization and as constituencies in their competition for power and resources" (Smith 2001, 55). This approach regards nationalism as a concept that becomes manipulated or politicized "for elites in competition for political power and economic advantage" (Brass 1991, 15). More explicit instrumentalist lines of approach arise from Claude Bontems and Pablo San Martin. Bontems describes the creation of the SADR (Sahrawi Arab Democratic Republic) ${ }^{37}$ constitution as one that would avoid the extermination of Sahrawi cultural identity and "reassert their independence" (Bontems 1987, 172). This statement highlights what the POLISARIO has understood to be true all along - that at one point the people of the Western Sahara were once free.

The POLISARIO example suggests that in one move both created and appropriated the anti-colonial struggle, and expanded it to include full independence ever since $1975^{38}$. Others, such as Randa Farah, Greg Noakes and Janet McMahon ${ }^{39}$, including David Seddon, agree that what may have been considered as small glimpses of identity differentiation were transformed into certain 'political realities,' namely ethnonationalism, due to elitist group manipulation. They have argued that groups such as the Harakat $\mathrm{Tahrir}^{40}$ and the POLISARIO developed much of the Sahrawi consciousness. Other more extreme suggestions indicate that from the mid to late-1960s, international governmental organizations such as the UN and the AU were pushing for selfdetermination of the Spanish Sahara (San Martin 2010, 61 and 64). Exaggerated as these ideas are, they have played a part in the push for Western Sahara sovereignty. What they do not show,

\footnotetext{
${ }^{37}$ The SADR is the government-in-exile of the Western Sahara proclaimed on February 27, 1976 by the Provisional Sahrawi National Council of the POLISARIO Front.

${ }^{38}$ This was the year that Morocco initiated the Green March and invaded the Western Sahara.

39 Greg Noakes and Janet McMahon, "Sahrawi Broadcaster Describes Western Sahara Freedom Struggle," The Washington Report on Middle East Affairs 11 (1993), 44.

${ }^{40}$ Anthony Pazzanita, Harakat Tahrir Saguia El-Hamra wa Oued Ed-Dahab (Movement for the Liberation of Rio de Oro and the Oued Ed-Dahab), Historical Dictionary of the Western Sahara, (Scarecrow Press: Lanham, MD): 2006, 186. This was the first serious group to challenge the Spanish colonial presence since the Army of Liberation in 1958. It was created in December 1967 but lasted only through mid-1970 with the death of its leader, Mohammed Sidi Ibrahim Bassiri.
} 
however, is that there have been a small number of elites before the nineteenth century that brought together the tribes of the Western Sahara. This study focuses on searching for those elites, group leaders that may have united ancestral tribes of the Sahrawi. Thus, instrumentalism encourages us to consider a group's hold on Sahrawi national identity.

The challenge for this study was locating specific works that wrote about the region and whose focus was on a particular leader or group of elites. There is work on the early Almoravid and Almohad dynasties recording their conquest in the greater Western Sahara. These works, however, do not make any association with the modern Sahrawi. Apart from the Cambridge History of Africa Volumes, Abun -Nasr, Julien, and Laroui, most of this history is found in reference or encyclopedic works that are mainly general in nature. The works that do refer to populations groups comment on tribes and their relationships with each other, emirates and with the Sultan of Morocco. Some of the history that refers to specific instances of leaders attempting to unite tribes is about the struggles of the Sultans. The Sultans of northern Morocco ventured from their bases in the capital cities of Fes and Marrakesh mostly to consolidate territory based on religious (conversions), economic (securing the trade routes) (Lydon 2009; McDougall 2012), and blocking foreign intrusion (European colonization). Little is mentioned about the unification of tribes.

The nature of leadership, especially about the Sultan's power, will be discussed. These details represent the limitations of power of the Sultan over the greater Western Sahara. The literature provides examples of historical territorial autonomy the POLISARIO claim make them distinct from Morocco. They provide elements of separateness from Morocco but little to the search for the origins of Sahrawi identity. The most important figure, claimed by both Morocco and the POLISARIO, that lends itself to instrumentalist arguments, is Ma' al-'Aynayn. $\mathrm{He}$ is perhaps the only personality that comes close to leading a diverse set of tribes. Although he figures prominently in Western Saharan history in the early twentieth century, he does receive 
wide study. Only a handful of scholars (Mahmud Awa 2015; Ould Mohamed 2010; Pham 2010; Mundy 2008; Bank and Van Heur) comment on Ma' al-'Aynayn. These works, however, give few details of his exploits or briefly mention him as evidence in the 1975 Advisory Ruling of the ICJ in support of the Sahrawi. Apart from these few works, little else has been added supporting Sahrawi identity through instrumentalist arguments until the creation of smaller groups after Moroccan independence.

\section{Constructivism}

Constructivism, based on earlier ideas of J.G. Herder, Renan, and Weber, rejected that nationality or even ethnicity was the essential human condition but rather believed that nations were products of socialization and historical forces. Herder believed that certain outstanding factors (education, physical environment, intermarriage, and tradition) influenced the national soul (Ergang 1966, 112). Ergang explains that Herder saw "nationality as a product of nature and its growth as regulated by the laws of nature," where nature "was the great architect who planned and constructed the group" (95). Renan held that "un nation est un âme [soul], un principe spirituel." $(1882,8)$ Two things constitute this soul, the spiritual principle "one is the possession in common of a rich legacy of memories and the other is the actual consent, the desire to live together, the will to continue to emphasize the heritage we have received undivided" $(1882,8) .{ }^{41}$

Gellner extends Ernest Renan's statement and writes that a nation can "be defined in terms both of will and of culture" only "when general social conditions make for standardized, homogeneous, centrally sustained high cultures, pervading entire populations and not just elite minorities" $(1983,54)$. Anderson in his most quoted of phrases declared that a nation is imagined

\footnotetext{
41 Direct translation of Ernest Renan's quote: 'L'une est la possession en commun d'un riche legs de souvenirs; l'autre est le consentement actuel, le désir de vivre ensemble, la volonté de continuer a faire valoir l'héritage qu'on a reçu indivis" from Qu'est-ce qu'une Nation?, Conférence faite en Sorbonne, March 111882 in E. Renan, (Textes de Barrès, Daudet, R. de Gourmont, Céline), chapitre 2, 12-48. Paris: Pierre Bordas et fils, Éditeur, 1991, 128 pp. Collection: Littérature vivante, 50.
} 
as limited (because it has finite boundaries), sovereign (born in the Age of Enlightenment and revolution), and as a community, (conceived as a deep, horizontal comradeship): "it is an imagined political community" $(1983,17,19)$. This approach should help determine if sociohistorical conditions have constructed a Sahrawi movement that has been able to produce, if not, forge such a national soul - a Sahrawi nation. Eric Hobsbawm contended that nations should be analyzed not only from above "in terms of political, technical, administrative, economic, and other conditions," but also from below "in [subjective] terms of the assumptions, hopes, needs, longings and interests of ordinary people" $(1990,10)$.

Hobsbawm also tended to believe that nationalism produced nations in contrast to John Armstrong's Nations before Nationalism hypothesis. This approach is the most difficult for evaluating Sahrawi identity. Scholarship over the issue of the Western Sahara and Sahrawi nationalism is most often depicted as an outgrowth of modernity, and it is usually characterized as a product of anti-colonialism. Most authors account for the rise of Sahrawi nationalism only as late as the 1960s or 1970s. Very few have noted any earlier periods of national mobility. John Mercer had written a study describing how cycles of invasion and unification had forged the Sahrawi nation. For example, David Seddon wrote that strong ultra-nationalism in the northwest region of the Maghreb began in 1944 with the Istiqlal (Independence) Party of Morocco (1987, 39). This later evolved into the 1956 ALS (Army of Liberation for the Sahara), which was a small group of ultra-nationalists who sought other "occupied" areas — Tangiers, the Spanish deserts of the South — "the Sahara from Tindouf and Atar and the Algerian-Moroccan borderlands" (Hodges 1984, 88). Tony Hodges described the rise of Sahrawi insurrection stemming from Morocco's independence movement in 1956, "which first inspired the ahel essahel to rise in revolt - against the French in southern Mauritania and southwest Algeria as well as the Spanish in the Western Sahara" (ibid., 85). These implicit notions indicate that they are more constructivist in nature. 
In a relatively lesser-known work, Ramón Criado writing in 1977, designated the criteria of history, geography, and the structures of society as elements of differentiation of the Sahrawi from their supposed Moroccan or Mauritanian origins (67). Criado develops the distinctiveness of the Sahrawi by tracing tribal affiliation to the territory approximating the area of Sequiet elHamra y Río de Oro. By the sixteenth century, he states that there arose not only a certain hierarchy among the tribes, but also a strict territorial localization that is respected even today by the tribes of the $\mathrm{SARIO}^{42}$. He believes this proves that an independent and coherent nucleus existed both before Morocco constituted itself as a Kingdom, and before Mauritania splintered into emirates (due to the decline of the Negro empires) (Criado 1977, 78). In contrast, within this historical context, Osama Abi-Mershed and Adam Farrar write that the lands, which constitute modern-day Western Sahara, have been under intermittent Sharifian (spiritual) authority that began in the eleventh century (Abi-Mershed and Farrar 2014, 7-9). These writers attribute geopolitical and socio-cultural command of the region due to the 'spiritual' authoritative attachments given by the inhabitants to the Alawite Dynasty (ibid., 10).

Joshua Castellino and Elvira Dominguez-Redondo state that Sahrawi national identity is difficult to establish because the distinctive claims of territoriality and spiritual authority by either side are blurred when faced with pinpointing the variable tribal allegiances throughout the long history of the area. The authors tend to lend credence to the 'general' idea of a monarchical division of rule between "a domain of sovereignty (Bled el-Makhzen) and a domain of suzerainty (Bled as-siba)" within the empire $(2014,32)$. Castellino and Dominguez-Redondo state that the most controversial issue that surrounds the Western Sahara conflict involves the territorial limits of the Sharifian Empire. They write that the differences are not only territorial but also perhaps ethnic: The mostly Arab makhzen always struggled to maintain order in the mainly Berber as-siba

\footnotetext{
${ }^{42}$ From the Spanish and translated by the author: "proviene la localización territorial estricta que respetan hasta hoy las tribus del Sario." The designation, 'the tribes of Sario' (Sp. tribus del SARIO) by Ramón Criado refers to the area of Saguía el Hamra and Rio de Oro. This is also the suffix abbreviation taken by the POLISARIO. Ramón Criado, Sáhara: Pasión y Muerte de un Sueño Colonial, Ruedo Ibérico: 1977, 77.
} 
lands. Thus, the author encountered not only literature that mentioned physical boundaries (ICJ, 1975) but also literature that documents certain concepts of differentiation. Scholars in this area (Lopez Bargados 2003; Ould Mohamed 2010; Hodges 1983; Norris 1986; Criado 1977; Moya Fernández 2009) write about boundaries of governance: bilad as-siba, bilad al-makhzen, trab albidan, and 'Jat al-Jaof.' These notions are historical distinctions of identity that soon became part of the debate over territorial autonomy in the Western Sahara.

Others take a more legal approach to the construction of Sahrawi arguing on the basis of treaties. Of these, most mention the Treaty of Alcaçovas (1479) and the Treaty of Tordesillas (1494), where one finds the first documented evidence of recognition of dominion by the crown(s) of Spain and Portugal over territory in both the Americas and Africa. These offer little demonstrable proof of control over the areas inland from the coast of the Western Sahara. Other authors assert that the treaties of Marrakesh (1767), Meknes (1799), and Tetuan (1860) are key markers for identifying the possession or non-possession of areas now considered to be Western Sahara proper. Even though the early treaties that were presented to the International Court of Justice, there were still contentious issues over the interpretation of these written documents, after the ICJ ruling. Authors such as Zunes and Mundy (2010), Rézette (1975), Criado (1977), Alguero Cuervo (2006) all comment about these treaties in their respective works. With the exception of Rézette, the rest favor POLISARIO claims.

Some authors have made the explicit argument that the origins of Sahrawi national identity are socially constructed. For example, Zunes and Mundy who have written a comprehensive analysis of the Western Sahara state that, "the 'idea' of a Sahrawi people...is recent" and "is the outgrowth of the colonial dialectic" $(2010,91)$. In fact, they state that their book was written on "the premise that identities are made" and "not found" (ibid., 95). They posit very strongly that all identities, speaking of Algerian, Moroccan, Mauritanian, as well as Sahrawi "are not given; they are the outcome of the historical interaction of dominant and 
subordinate social forces" (ibid., 111). Hodges much earlier had written that the "Western Saharans never constituted a nation in pre-colonial times, and their present-day nationalism is a very recent phenomenon, which took root only in the latter part of the Spanish colonial period" $(1983,28)$. He declared that the Sahrawi had "no historical antecedent" but did raise a curious point by stating that they, "in a broad cultural sense, have a common identity vis-a-vis the predominantly Berber sedentary or semi-nomadic populations to their immediate north, in southern Morocco, beyond the Ouarkziz and Bani mountains and the Oued Draa" (Hodges 1983, 28 and 30).

Pablo San Martin has written along constructivist lines as well by attributing Sahrawi national development to Spanish colonial policy. The 1960s and 1970s brought about many economic and administrative changes to the Western Sahara. The discovery of phosphates, the change in governance, and the subsequent social status of the inhabitants of the Western Sahara were all due to Spanish colonization. San Martin concluded that it was not the change of the asabiya $^{43}$ to a more urban, individualized, capitalist society that allowed for more collective action among the Sahrawi but "new forms of collective solidarity and action" that had emerged from formal colonization (San Martin 2010, 56). For example, Martin stated that the new system of: "Representation of the native population of the Spanish Sahara was designed based on the assumptions that the tribes were still the main social institutions organizing the social life in the province and delineating the identities of its indigenous inhabitants (ibid., 61). The tribal institution as the primary social structure utilized toward some cohesive action, had been debilitated because of these above changes. San Martin described these colonial attempts at administering the Spanish Sahara as "Francoist strategies of control" (ibid., 65).

\footnotetext{
${ }^{43}$ Asabiya, in the modern period, the term is generally analogous to solidarity. However, the term is often negatively associated because it can sometimes suggest loyalty to one's group regardless of circumstances, or partisanship. Shelagh Weir, A Tribal Order: A Tribal Order: Politics and Law in the Mountains of Yemen (Austin: University of Texas Press, 2007), 191.
} 
One of the few authors who assessed Sahrawi 'nationality' within any theoretical blendprimordialism within the context of constructivism - was Sidi Mohamed Omar. He expressed that, "there is much evidence that prior to Spanish colonization there was a widespread sense of belonging to the Western Sahara as a distinctive territory with a distinct population" (Mohamed Omar 2008, 44). Yet, in the very next sentence he stated that "the majority of the inhabitants 'imagined' themselves as a sociopolitical community" and added later that the formative phases of Sahrawi national identity were forged in constructed or "performative acts"” (ibid., 44). His comments are well placed within the constructivist notion, but they did not serve the primordial approach well with only one reference. In general, most modern scholars tend to contextualize Sahrawi identity through constructivist arguments.

This literature review is in need of more scholarly work in the area of national identity, especially in the case of the Sahrawi. Most pro-POLISARIO or pro-Sahrawi scholars who claim that the origins of the Sahrawi are found in the past and are tied to distinctive features of their identity, place primordial arguments above all others to justify Sahrawi claims. However, they face an uphill battle because the theory has been absorbed in the popular approach of constructivism. A resurgence of energy surrounding primordialism did gain traction with the fall of communism but it has since begun to dissipate once again. Scholars pursuing instrumentalist arguments are few and of these, most will discuss the POLISARIO's management of Saharawi identity. More research is needed. I hope to add to the academic field of identity politics and bring Sahrawi identity to more prominence with this study. I apply equal importance to all three approaches. I may, however, be labeled a proponent of primordialism because I agree with Anthony Smith's notion that a nation may be constructed from socio-historical forces but founded upon ethno-cultural resources that have been developing for some time. 


\section{ARE THE SAHRAWI OF ANCIENT ORIGIN? INVESTIGATING THEIR 'NATIONAL' IDENTITY UNTIL 1524}

This chapter analyzes the possible ancient Sahrawi origins (assuming that Sahrawi history can be traced to its original inhabitants) in North Africa until the takeover of the Spanish fort at Santa Cruz de Mar Pequeña (located in southwestern Morocco) by the Arab army of the Sa'adian Dynasty in 1524. Most, if not, all of this part of the analysis will be based on historical research of the period in the western and southwestern Maghrib region. It will trace the lineage of the Western Saharan population and provide insight to the claims of cohesion and group development throughout this early period. The hypothesis that the origins of Sahrawi identity can be traced to antiquity derives primarily from a primordial approach to the creation of nations and nationalism and is rooted in a connection to the past. Leaders of the POLISARIO ${ }^{44}$ movement and certain scholars who investigate Sahrawi identity have claimed that they are a distinct group of people separated by identifiable cultural markers. They conclude that the national identity of the Sahrawi is linked to the past and has distinctions that set them apart from present-day Moroccans. This chapter seeks evidence that sustains the argument that the Sahrawi have had a distinctive and continuous historical record. The search will include late antiquity, the beginning of the Roman period, the Arab incursion into North Africa, and later the medieval period.

First, an extensive section will chronicle important events and information that discuss the markers of Sahrawi national identity and the arguments that sustain Sahrawi claims about the past. A second section centers on the deficiencies that emanate from primordial explanations and will focus on each historical period to provide some insight and criticism of the primordialist approach. This will link the primordialist discussion toward other considerations that resonate with instrumental and constructivist theories of Sahrawi national identity. Despite the paucity of

\footnotetext{
${ }^{44}$ Spanish acronym for the Frente Popular de Liberación para Saquiat el-Hamra y Río de Oro (Popular Front for the Liberation of Saquiat el-Hamra and Rio de Oro [River of Gold]). The POLISARIO are the liberation group seeking the independence of the region claimed and administered by the Kingdom of Morocco called the Western Sahara.
} 
evidence for the primordial origins of the Sahrawi in this case, it is the objective of the author, not to discount Sahrawi links to the past, but to highlight these claims in order to understand their national origins. In essence, even if the primordial theory does not fully explain this case, it is important to look at the evidence, since political actors try to use this approach.

The Lybico-Berbers: Proto-Sahrawi Nation? Ancient Origins - 1000 BCE

It is difficult to pinpoint with historical accuracy the origins of any nation or national identity of a specific group. In general, it is easier to determine the establishment of a nation-state in our modern world with the criteria that are attributed to such an entity than to trace the lineage of an ethnic group. However, this study explores the origins of a putative national people, not of the political entity that claims to represent them. ${ }^{45}$ Although several scholars mention that the Sahrawi are the direct descendants of the Sanhaja Berber, most of the anthropological, ethnological, and geographical scholarship has not been able to agree on the point of departure for the settlers of North Africa. Some scholars believe these settlers were the product of migration patterns from the East, others from the South due to increasingly arid conditions, and still others from across the Mediterranean (Laroui 1977, 17). These migration patterns are theorized to have originated from Asia through two routes. One route developed from the northeast via Europe and the other stemming from the southeast, which traversed East Africa. Scholars from the colonial period have theorized that their ancestors are of immigrant waves from the Mediterranean that included Celtic-Iberians and Semitic peoples [i.e., Phoenicians] ${ }^{46}$ (Bullard 2001, 184). Bullard states there is yet another theory that posits that the Berbers together with the Egyptians formed the 'white African race' (Ibid., 184). However, according to modern scholarship, the tendency

\footnotetext{
${ }^{45}$ In fact, the establishment of such an independent entity, in this case the Western Sahara, cannot be appropriately discussed here because not only is its status unclear, but it also continues to suffer from the problem of qualitative and quantitative recognition by other nation-states.

${ }^{46}$ Reuben G. Bullard, "The Berbers of the Maghreb and Ancient Carthage," in Africa and Africans in Antiquity, ed. Edwin A. Yamauchi (East Lansing, MI: Michigan State University Press, 2001), 184.
} 
now is to attribute the Berber to a composite of races where the distinct characteristic features of the Mediterranean-type predominate. These findings indicate that origins of the Berber are diverse, but nevertheless, maintain that they are indigenous to North Africa after settling those areas during 8000 and 7000 BC (Laroui 1977, 17; Bullard 2001, 184; Ilahiane 2006, xxxi; Ghirelli 1942, 8).

Evidence for the rise of a proto-Sahrawi nation usually begins at the beginning of the first millennium (AD) and traces the forerunners of the Sahrawi to Sanhaja affiliation. These scholars believe that the ancestors of the Sanhaja were a branch of an ancient group of people known as Berber $^{47}$ (or Imazighen $^{48}$ ). By $1000 \mathrm{BCE}$, the Berbers, who most agree are the direct ancestors to the Sahrawi, had successfully settled across North Africa and pushed another group termed the Bafour (or Bafots) to the south. According to these authors, the Berbers can be traced from before the Bronze Age $(\approx 3300$ BCE). However, a few authors locate 'Berber ancestry' much earlier in antiquity, deep into the Paleolithic period (>10,000 BCE). Mundy has written that the culture believed to "represent the direct ancestors of the Imazighen, the Capsians," appeared 10,000 years ago during the 'Wet Phase,' which "allowed humans to return to the Sahara" after a long arid four thousand-year period (Mundy 2007, 305). For instance, Ilahiane writes that the historical record demonstrates a group called the Siwa, who are of Berber origin, have been in existence since 10,000 BCE (Ilahiane 2006, 112).

Yet, Munene suggests that the "hierarchic identity of the Western Sahara" can be traced much earlier to the Bafour but around 5500 BCE (Munene 2010, 84). Almost a century ago,

\footnotetext{
${ }^{47}$ The use of the word 'Berber' is one that has been applied externally and is not actually used by Berbers themselves. The actual denomination of 'Berber' is generally attributed to the Latin plural form of barbari (sing. barbarus) and the Greek use of barabaroi. Hsaine Ilahiane, introduction to Historical Dictionary of the Berbers (Imazighen), Historical Dictionaries of Peoples and Cultures, no. 5 (Lanham, Maryland: Scarecrow Press, 2006), xxx. Also see Angelo Ghirelli, El País Berebere: Contribución al Estudio de los Orígenes, Formación y Evolución de las Poblaciones del África Septentrional (Madrid: Editora Nacional, 1942), 6.

${ }^{48}$ In the Berber language of Tamazight, "Berbers use the name 'Imazighen' to describe themselves (singular masculine is Amazigh; singular feminine is Tamazight)." "Today, Berbers use the collective designation 'Imazighen,' and Imazighen is the word that embodies the Amazigh sense of being the real and essentially human beings of their homeland, called Tamazgha." Ilahiane, Historical Dictionary of the Berbers (Imazighen), xxx.
} 
Lucas wrote: "One must admit that the base of the apparent Arab and Berber population had been preceded by Bafour elements, of [later] vanquished groups..."49 (Lucas 1931, 152). Others, such as Mercer (1976a, 498), Hodges (1983, 3), and Jensen $(2005,21)$ attribute the existence of the Bafour to oral history at this time in the region. Legal scholars, Castellino and DominguezRedondo (2014, 39), Mwalimu (2010, 952-953), historical sources such as $\mathrm{Webb}^{50}(1995,28)$ and Jensen (ibid.) suggest the Bafour were a group of people that migrated or 'gravitated' south into the Sahara. Yet, Pazzanita writes that the "black-skinned" Bafour apparently had emerged from sub-Saharan Africa, mixed with a northern (Rif and Atlas) mountain-living group moving south, and produced the 'Amaziah' (Imazighen) or, as mentioned above, Berber. (Pazzanita 2006, 383)

There are conflicting views about the migratory patterns of the probable Sahrawi ancestors, but most scholars agree that over time a 'Neolithic' $(\approx 10,200-3000$ BCE) group from the eastern Maghrib or western Mediterranean began moving south and southwest, encroaching on the desert. Western Sahara scholars cite archaeological evidence of the Bafours moving and living in this area between 5500 and 2000 BCE. The depiction of domesticated animals began to appear in cave paintings ${ }^{51} 5500$ years ago throughout the Neolithic Age (an era that is marked by abundant wildlife, domesticated animals, and a complex culture) in the Sahara. Despite the contradictions in academic and archeological literature over the migratory patterns of the Bafour, most agree that they settled in the region now considered greater northwest Africa (including modern Mali, Mauritania, Morocco, the Western Sahara, and Algeria). By the second millennium,

\footnotetext{
49 Taken from the French: "On doit admettre que le fond de la population apparente arabe et berbère a été précédé d'éléments Bafours, de groupes vaincus...” A.J. Lucas, "Considérations sur l'Ethnique Maure et en Particulier sur Une Race Ancienne: Les Bafours,” Journal de la Société des Africanistes, Tome 1 Fascicule 2 (1931), 152.

${ }^{50}$ Yet, Webb, in both his accounts on the Bafour describe them as a group who were still in existence only centuries before 1600-1850. How many centuries before then is not made clear. He speaks of the Bafour as surviving as villagers $\approx 1450-1600 \mathrm{AD}$ in the Gibla region (southwestern Mauritania near the Senegal River) but later "absorbed into the ethnic categories of Wolof, Berber, and Peul... and thus remains somewhat mysterious." James L. A. Webb, Jr., Desert Frontier: Ecological and Economic Change along the Western Sahel, 1600-1850 (Madison, WI: University of Wisconsin Press, 1955), 15, 28.

${ }^{51}$ The most notable found in Tassili n'Ajjer (Plateau of the Chasms) in southeastern Algeria.
} 
the available artifacts depict a Negroid people who were largely pastoral but later frescoes "begin to show elongated white men with characteristic long hair and pointed beards" (Brent and Fentress 1997, 19). These and other groups from both the east and west of the Sahara came to be called the 'Berbers,' overwhelmingly agreed upon by scholars and through archeological evidence as the original inhabitants of North Africa.

Unfortunately, there is very little written about Berber culture for the northwestern Sahara. Most accounts provide proof from frescoes, rock carvings, paintings, and settlement sites in the 'highlands' of North Africa in modern-day Algeria (Tibesti, Tassili, the Hoggar) ${ }^{52}$ to the Atlantic coast and into the Saharan Atlas Mountains. (Ilahiane 2006, 17) Beyond these areas, much remains to be explored, assessed, and recorded. There is a rich and diverse archeological record in the Western Saharan both in the administered areas by Morocco and in the 'Free' or 'Liberated Zone' now under POLISARIO control. For instance, several stone structures (Tifariti, Bir Lehlou in POLISARIO-controlled Western Sahara, Bir Lemuesat in northern Mauritania), ${ }^{53}$ rock paintings and engravings (Sluguilla, ${ }^{54}$ Bou Dheir and Erqueyez ${ }^{55}$ near Tifariti, Zug on the POLISARIO side of southern Western Sahara, and Wadi Zenta in the Zemmur of northeastern

\footnotetext{
${ }^{52}$ Tibesti are a set of mountains located in northern Chad well-known for rock and parietal art. Tassili n'Ajjer is listed as a World Heritage Site because "of its geological formations including 'forests of stone', biological diversity, archaeological importance and prehistoric rock art (24)...The art itself comprises paintings and engravings on exposed rock faces, and includes pictures of wild and domestic animals, humans, geometric designs, Libyc and Tifinagh inscriptions (ancient and recent Tuareg/Berber script) and a very few plants and trees (29)...Tassili $\mathrm{n}$ Ajjer is a Tamahaq name meaning 'plateau' of the Ajjer people, the name of the Kel Ajjer group of tribes whose traditional territory was here" (24). David Coulson and Alec Campbell, "Rock Art of the Tassili n Ajjer, Algeria," Adoranten, Scandinavian Society for Prehistoric Art, 2010, Underslös Museum Tanum Rock Art Research Centre, accessed July 5, 2016, http://www.rockartscandinavia.com/rock-art-of-the-tassili-n-ajjer-algeria-by-david-coulson-and-alec-campbellaa11.php. The Hoggar or Ahoggar is a mountain range in central southern Algeria where, along with Tassili, are found the richest concentration of prehistoric rock art.

${ }^{53}$ Many of these stone structures have been characterized as funerary monuments, comprising "tumuli, linear stone arrangements, and stone enclosures...isolated menhirs or standing stones" and others "with apparent astronomical functions." Nick Brooks, "Cultural Heritage and Conflict: The Threatened Archaeology of Western Sahara," in The Sahara: Past, Present and Future, ed. Jeremy Keenan (New York: Routledge, 2007), 285-291, Google Play Books.

${ }^{54}$ Sluguilla is located in a zone situated in the Hamada, a stony desert that extends along the Northern part of RASD and to the West of Algeria.

${ }^{55}$ Erqueyez has also been transcribed as Rekeiz Lemgasem or Erquiez.
} 
Western Sahara), pottery, and tools have been found depicting domestication of animals, cattlegrazing, and preoccupations "with astronomy" (Brooks et al 2003, 3-4; Keenan 2007, 285-291). These and many other forms of Saharan rock art investigated in the 'southern provinces' and High Atlas Mountains of Morocco as well as in sites in Mauritania (Tagant, Adrar) are dated 2500-500 BCE based on its depictions of chariots, horses, saddled horsemen, dromedaries, and the appearance of the Lybico-Berber (or Tifinagh) alphabet (Soler Subils 2007, 16-18; Le Quellec $2008,72-73 ; 2016,55-56)$.

Most scholars of identity politics will agree that the major distinguishing features of an ethnic community are language, attachment to territory and a common culture. However, these ethnic distinctions are perhaps the most challenging in establishing a cohesive Berber identity. For example, according to Marçais, the principal difference between Arabs and Berbers is language. (Marçais 1955, 22) Yet, Berber scholarship in the area of deciphering ancient scripts used in North Africa is still challenging. McDougal writes that "samples of the ancient language that contemporary prehistorians and classical scholars term 'Lybic' or 'Libyan,' and which Berber writers... assert unproblematically to Tamazight [modern Berber] ..., are general untranslated and frequently indecipherable" (McDougall 2003, 69). The Berber script is based "on the assumption of a coherent social and linguistic continuum of the native population persisting from pre-Punic times to the present day ..., [which] though not disprovable, extremely fragile" (Millar 1968, 128). Millar adds that even though there is concrete evidence of an ancient 'Libyan' (Berber) script distinct from Punic (Carthaginian), it "may, or may not, be the, or an, ancestor of present-day Berber" and "the precise connection between the two may perhaps never be known" (Ibid., 128-129).

Secondly, the area of early Berber occupation has been difficult to establish—both its nomadic range and the "homeland" of its sedentary populace. Extensions of their historical homeland have reached even beyond the Sahara Desert. For instance, there are claims of Berber 
populations 1) at the time of the Moorish ${ }^{56}$ invasion (711-719 CE) of the Visigoths and the native Romans of Hispania on the Iberian Peninsula; 2) as far eastward as Egypt in the Siwa Oases and the Nile River valley; and 3) off the coast of northwest Africa among the Canary Island inhabitants. The continual desiccation of the environment and, as a result, the migration toward the Atlantic coast, closer to water, resulted in the development of more a agro-pastoral lifestyle. There is evidence not only of irrigated cultivation but also of trade between the Fezzan (Lybia) and the western Sahara, especially in beads and slaves. Yet, "sedentism" may have been 'temporary,' a seasonal symbiosis of nomadism and sedentary life (Challis et al 2007, 286, 290). Still, debates continue about the nomadic nature of much of the Berber population and thus how to differentiate them from other invading groups across North Africa.

Third, much of the work that relates to 'Berber' culture is ongoing and unfinished. "By the middle of the second millennium the frescoes show men using horses to pull light war chariots, armed with spears and wearing kilts similar to those of the Egyptians...perhaps aimed at a perpetuating the social hierarchy" of a priestly caste. (Brent and Fentress 1997, 19-20) The domestication of horses seems to have taken place giving these groups more mobility, increasing "nomadic pastoralism" in "the now arid steppe areas of the Sahara" (Ibid., 20). Brent and Fentress add that the depictions of wall art and evidence from physical anthropology represented a more mobile, 'whiter' Berber populace that acquired new technology and a more stratified society which "enabled them to subjugate their existing black population" (Ibid., 20). This "white invasion' of the Sahara was the beginning of Berber domination, displacing the Negroid race ${ }^{57}$.

\footnotetext{
${ }^{56}$ The invasion of the Moors was led by an African Berber general named Tariq ibn Ziyad who after an eight-year campaign brought most of the Iberian Peninsula under Islamic rule. New World Encyclopedia, s.v., "Moors," accessed June 23, 2016, http://www.newworldencyclopedia.org/entry/Moors.

${ }^{57}$ However, the rise of the Berber did not entirely eliminate blacks from North Africa. In fact, Brown adds that "there have always been blacks in Northern Africa. The blacks have never, however, really represented a group or nation and, consequently, they have never constituted a threat to the non-Saharan Northern Africans." For instance, Brown includes a quote from Raymond Mauny from “Tableau Geographique de L'Ouest Africain au Moyen Age," Memoire IFAN, no. 61 (Dakar, 1961), 397, who estimated that during the Middle Ages at least twenty thousand black were sent each year from West Africa into North Africa, or at least two million per century. Additionally, Brown adds that blacks 'returned'
} 
Nevertheless, Soler Subils concludes that because "very few archaeological excavations have been done in the Western Sahara, we still have no clear and safe sequence of the prehistoric cultures that occupied the region. As a consequence, it is difficult to link any of the rock art remains with a prehistoric culture" (Soler Subils 2006).

Today, there are still many questions about Berber origins. Anthropologists and ethnologists differ on the exact genealogical identification and characteristic quality of Berber ethnicity. Brent and Fentress stated that "the only certainty is the [Berber] population by the second millennium was extremely heterogeneous, with a range of Mediterranean types mixed with some descendants of the original, possibly indigenous 'Meka' type" (1997, 17). Marçais stressed that " $[t]$ he few clues so far obtained from prehistory lead one to believe that the Berbers do not constitute a homogeneous race...From an anthropological point of view, therefore, North Africa shows great diversity, which has been further accentuated by numerous interminglings between different types of Berbers as well as of Berbers with many other racial elements" (Marçais 1955, 22). Ilahiane added that there has been an "ethnocultural symbioses [of the Berbers] with the conquerors" over the centuries (Ilahiane 2006, xxxii). What is more than certain is that the Berber had been tribal "from the earliest known periods of their history" and that "their final allegiance was to a tribe, or to a real or imagined ethnic bond uniting the individual to a part of the race but never to the whole. Thus a Berber consciousness [had] never existed" (Abun-Nasr 1971, 8, 58). Nevertheless, anthropological and historical scholars have consented that a composite group of Lybico-Berbers had established themselves across North Africa from the Red Sea, across the vast Saharan interior, stretching to the Atlantic Ocean and into the Western Sahara.

to "Northern Africa as detribalized individuals, usually as slaves" in great numbers and "as random individuals soon scattered over Northern Africa" that were easily absorbed or ignored. Leon Carl Brown, "Color in Northern Africa," Daedalus 96, No. 2 Color and Race (Spring 1967): 466-467. 
The Gaetulian Berbers of Northwest Africa - 500 BCE to the Arab Invasion

Modern scholarship, at this stage in history, agrees that the Berbers, labeled as ancestors of the Sahrawi, begin to divide into separate social and political entities. The natural course of discussion about Sahrawi history moves to identify these North African groups that can be used as reliable sources for tracing their own national identity. In addition, the discussion now begins to narrow its geographical scope from the huge region of North Africa to the more specific areas of modern-day southeastern Morocco and Western Sahara proper, including parts of Mauritania. Still a relatively pastoral people, the eastern (from the relative domains of present-day eastern Morocco, Algeria, Tunisia, and Libya) Berbers of littoral North Africa mimicked the agricultural and politico-military status of the Roman Empire. Most information about the western and southwestern Berbers include the Mauri and the Numidae ${ }^{58}$, who despite gravitating toward a more sedentary existence, retained a thriving nomadic lifestyle, and established kingdoms to the west of Carthage (mentioned briefly in the previous section). These groups (mentioned below), unlike those farther east, did not rush to emulate the flourishing Roman and Carthaginian civilizations

The peak of the Carthaginian Empire took place in the fifth century BCE and for the next 400 years, became preoccupied with Roman competition. Carthaginian control in the region had been limited to its vassal city-states along the North African coast, a few inland territories in northern Tunisia, and (modern-day) northeast Algeria. Carthage ${ }^{59}$ did not extend its control

\footnotetext{
${ }^{58}$ Numidae or Numidia is "the region that stretches west of Carthaginian territory between the Tusca and Ampsaga rivers, today part of eastern Algeria. The Greeks interpreted the name of the Libyan people of Numidia living in this

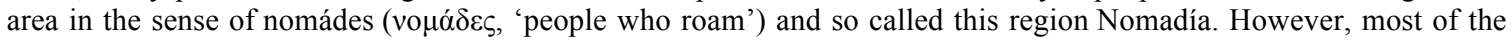
Numidae had already been settled for a long time. The plateau of Numidia is bordered in the North by the foothills of the Tell Atlas and in the south by the Sahara Atlas." Werner (Bamberg) Huß, Brill's New Pauly, German Version, s.v. "Numidae, Numidia," accessed 22 August 2014, in BrillOnline Reference Works, eds. Hubert Cancik and Helmuth Schneider, (Koninklijke Brill NV, 2012), http://referenceworks.brillonline.com/entries/brill-s-new-pauly/numidaenumidia-e826540.

${ }^{59}$ Carthage apparently had a mix of ethnic communities beginning with the founders of the city the Phoenicians and 'Lybians.' Since Carthaginian Empire extended itself extensively along the coast and found itself rivaling Greece and then Rome, many of its colonies, and as a result, subject people were "required to provide troops" such as the
} 
beyond these immediate dominions because it preferred to "cultivate friendly relations with the $\left[\right.$ Berber $\left.^{60}\right]$ chiefs, who included intermarriage between them and the Punic aristocracy...[and] for the purposes of trade and recruiting mercenaries from among their tribesmen" (Abun-Nasr 1971, 320). However, as the Carthaginian Empire grew stronger, three Berber Kingdoms arose to counter its rise: 1) the Massylii (Tunisia-Algeria), 2) the Masaesyli (northwestern Algeria), and 3) the Mauri (northern Morocco) ${ }^{61}$. Massylii and Masaesyli were later incorporated into the Numidian ${ }^{62}$ Kingdom under King Massinissa. These Berber Kingdoms flourished "between the destruction of Carthage and the establishment of effective Roman control over the Maghreb ${ }^{63}$ " (Encyclopedia Britannica, 15th ed., s.v. "North Africa"). The Mauri Kingdom was established in present-day Morocco and the Western Sahara and was ruled by several Berber kings until it

Numidians, Mauri and Iberian, Celto-Iberians from Spain These latter were comprised of several Berber tribesGaramantes, Gaetulian, Nasamones. Encyclopedia Britannica, 24, 15th ed., s.v., "North Africa," (Chicago: Encyclopedia Britannica, Inc., 2010), 956.

${ }^{60}$ According to Ilahiane, early Greek writers had used barabaroi for those groups that were "non-Phoenicians within the Carthaginian state" or for those who neither spoke Greek nor Latin. Pazzanita, Historical Dictionary of the Berbers, 2006, xxx. Abun-Nasr writes that the Romans had labeled the non-Greek and non-Latin speakers as barbari. Jamil M. Abun-Nasr, A History of the Maghreb, $2^{\text {nd }}$ ed., (New York: Cambridge University Press, 1975), 7. Ghirelli states that it was the Byzantines that had Hellenized the name to barbaroi and fashioned it to such an extent that it became common among city-dwellers to identify it with non-urban tribes. El Pais Berebere, 6-7. It is also possible that the connotation barabaroi came from the Greek for barbaros, which meant 'foreign' or 'strange.' Bullard, “The Berbers of the Maghreb and Ancient Carthage," in Africa and Africans in Antiquity, ed. Yamauchi, 183.

${ }^{61}$ The Mauri (Latin, Gr. Maurusii, and given by Romans as Mauretani) provided their name to modern Mauritania and originally lived between the Atlantic Ocean and the Wadi (river or dry river bed/valley) Moulouya (or Muluya) or the Chelif River. The Moulouya is located in modern-day northeastern Morocco and the source of its waters originate in the Middle Atlas and empties into the Mediterranean Sea. The Chelif River or Wadi ash-Shalif is the longest and most important river of Algeria and is located along the northeastern Algerian coast whose source originates in the Saharan Atlas and also empties into the Mediterranean Sea.

62 Bullard, Ilahiane, and Abun-Nasr all agree that the Greeks employed 'Libyan' as another name for the North Africans or non-Punic peoples and Numidian or "nomad" for the manner in which pastoralism was practiced.

${ }^{63}$ The term Maghrib, spelled occasionally as the Maghreb, is Arabic for 'west' and is referred to in Arabic as alMaghrib or Tamazgha ('land of the Berbers') in the Berber language. It is the region of north and northwestern Africa between the Atlantic Ocean and Egypt that comprises the coastal plain and Atlas Mountains of Morocco, together with Algeria and Tunisia and sometimes Tripolitania (Libya). Oxford Dictionaries: Language Matters, 2014 ed., s.v. "Maghreb," Oxford University Press, 2014, accessed July $24 \quad 2014$, http://www.oxforddictionaries.com/us/definition/american english/Maghreb?q=Maghrib. This text will use the 'Maghreb' spelling unless there is another spelling from a quote or in a title of a work that was cited or referenced in this study. 
became a Roman client state in 33 BCE. $^{64}$ After Rome's defeat of Carthage in $146 \mathrm{BCE}^{65}$, it maintained nominal control over North Africa. At this time, Roman North Africa was divided into four provinces: 1) Africa Proconsularis ${ }^{66}$ (the northern portion of Tunisia), 2) the Kingdom of Numidia, ${ }^{67}$ as a Roman client state, 3) "[t]o the west, in Mauretania ${ }^{68} \ldots$, [and] 4) the Gaetulians $^{69} "$ (Brett and Fentress 1997, 41).

The Berbers had not only founded kingdoms prior to Roman control, but had also established formal relations (including intermittent alliances) and initiated several revolts against the Roman Empire. These Berber kingdoms had, in general, transformed most of their nomadic people into a semi-pastoral or agricultural society. Mercer attests that, beginning in the first century BCE, the Saharan Berber had "been independent of the Maghreb" (Mercer 1976a, 498). One of these large Berber groups was, according to the ancient texts of Hanno, Pliny the Elder, and Ptolemy, called the "Gaetulians," who resided to the south and east of Roman control. Smith (who refers to German scholars Ritter et al 1817, 1034; Hornemann and Konig 1802, 223) ${ }^{70}$

\footnotetext{
${ }^{64}$ The Mauri (or Mauretania) Kingdom traditionally was located in present-day Morocco and although literature is scant surrounding their origins, there is mention of the Mauri and of an early King Baga ( $\approx 225 \mathrm{BCE})$ in Livy's Ad Urbe Condita Libri (History of Rome), Book 29.30 and in other ancient texts. The more notable rulers of the Kingdom of Mauretania were Bocchus I, Bocchus II, Juba I, and Ptolemy.

${ }^{65}$ Rome conquered the Carthaginian Empire, wiping out the city of Carthage and its inhabitants in the third Punic War of $146 \mathrm{BCE}$.
}

${ }^{66}$ Africa Proconsularis or Africa Vetus, governed by a proconsul (Roman provincial governor), was Rome's first African colony.

${ }^{67}$ This kingdom was previously divided between the ancient eastern and western Numidian monarchical tribes of Massylii and Massaesylli before uniting under King Massinissa (202 BCE) as a client of Rome with as much autonomy as possible in order to balance the power of Carthage.

${ }^{68}$ Mauretania had largely been an independent tribal Berber Kingdom since the 3rd century BCE but Rome had indirectly influenced Mauretania's politics through its neighboring wars with Carthage and Numidia. However, Mauretania did not come under Roman suzerainty until after the death of Bocchus II in 33 BCE.

${ }^{69}$ The Gaetulians were perhaps the largest of the Berber groups that dominated much of the interior of the Sahara. They were non-urban dwellers, thought to be pastoral-nomadic but archeological research has found they adapted irrigated cultivation but traveled considerably by horseback across the great Sahara to the Atlantic coast.

${ }^{70}$ Carl Ritter and Georg Friedrich Hermann Müller, Die Erdkunde im Verhältnisse zur Natur und zur Geschichte des Menschen, (1817) Vol. 1 (Berlin: G. Reimer, 1822-1859), 1034. Friedrich Konrad Hornemann and Karl Konig, 
writes that the Gaetulians "appear to be the chief ancient representatives of the great aboriginal people of modern Africa, who call themselves Amazygh or Amazergt, and to whom belong the Berbers of M. Atlas" (Smith 1854). Pliny wrote that Gaetulia extended as far west as "the Atlantic Ocean; and on the S. [sic] to a margin of the great basin of the river NIGIR [sic]," or, according to Pliny, "to the river Nigir $^{71}$ [sic] itself" (Smith, 1854). The Gaetulians were "primarily nomadic herder" slopes of the Atlas Mountains from the Aurés Massif westward as far as the Atlantic; southward it extended to the oases in the northern part of the Sahara" (Encyclopedia Britannica, 15th ed., s.v. "Gaetulian"). Mundy states that in the first century of the new Christian millennium: "The nomadic Gaetulians of the northern pre-desert, distinguished themselves by the fact that they lived 'outside the two great [Amazigh] kingdoms of Numidia and Mauritania, and resisted any attempts to tax or control them"” (Mundy 2007, 306).

According to Pliny, writing in the first century $\mathrm{AD}$, the two most powerful of the Gaetulian tribes were the Baniurae and the Autololes. The Baniurae occupied a more northerly area along the coast of then-Mauretania. The Autololes ${ }^{73}$ were the more powerful Berber tribe and although their exact dominions are difficult to identify, Idjennaden believes that their control was

Tagebuch seiner Reise von Cairo nach Murzuck, (Weimar: 1802), 223. Bayerische StaatsBibliothek Digital, accessed November 12, 2014, http://www.mdz-nbn-resolving.de/urn/resolver.pl?urn=urn:nbn:de:bvb:12-bsb10467058-2.

${ }^{71}$ It is not known with certainty which river basin of the Niger River Pliny was referring to. "As the limits of Gaetulia have not been settled, either by Ptolemy, or any of the other ancient geographers, it is impossible for us to define them...but notwithstanding the indefinite terms in which the ancients have laid this region, by comparing their several accounts and description....and, by consulting the observations of the moderns, conclude, that it could not have reached to any great distance in the Sahara." George Sale, et al, An Universal History: From the Earliest Accounts to the Present Time, Vol XVI, Part I (London: Printed for C. Bathurst [etc.], 1780), 166.

${ }^{72}$ Bob Idjennaden, The Forgotten Civilizations of Africa: The Gaetulian Warriors 3 (March 29, 2012), Kindle Edition for Mac.

${ }^{73}$ Translated from the French by the author, "Pliny the Elder describes them as barbarians particularly dangerous and always ready to pillage and massacre, but also seeking the alliance of less powerful tribes, the Darae and Daratitae of the Dra Valley, the Pharusi on the western slope of the High Atlas, the Masathi on the banks of the river Masath today oued Massa." Gabriel Camps, Les Gétules: Guerriers Nomades dans l'Africa Romaine, July 2002, accessed July 26, 2016 https://www.clio.fr/BIBLIOTHEQUE/les getules guerriers nomades dans 1 africa romaine.asp\#biblio. 
delimited by the Bou Regreg River in the north, to the south beyond the Sous region and in the Valley of the Dra'a ${ }^{74}$ (or sometimes spelled 'Draa,' now all areas of present-day Morocco) (Idjennaden 2012, 3.1). Farther south, in the vicinities of southeastern Morocco and the Western Sahara, stretching southwest toward modern Mauritania, there were other smaller groups such as the Canarii, Nigritae, Perorsi or Pharusii (see map 3.1) but they seem to have either disappeared or intermarried with other Gaetulian groups. Today, scholarly consensus indicates that the Gaetuli were a confederacy of tribes that included the groups ${ }^{75}$ mentioned above (Challis et al 2007, 290; Law 1978,143). Apart from the descriptions above, little else has been extracted about ancient Saharan Berber culture, history, and their territorial domain.

Any distinguishing characteristics between the Mauretanian (now modern Morocco and Algeria) and the Gaetulian Berbers is challenging. However, it has been determined that the kingdoms on the coast were more sedentary than those outside the Carthaginian and Roman sphere of influence. The Gaetulian Berbers were nomadic or semi-nomadic "part dwelling in tents... wandering about without settled abodes, and under no settled government" (Dictionary of Greek and Roman Geography, "Gaetu'lia," http://www.perseus.tufts.edu/hopper/text?doc=Perseus:text:1999.04.0064:entry=gaetuliageo\&highlight=gaetulia ),with evidence of horse-rearing, essential for traveling and trading over long distances, and depicted as barbarous and warlike by classical writers (Challis et al 2007,

\footnotetext{
${ }^{74}$ One source indicates that there was perhaps a legendary Kingdom of the Dra or a people mentioned as the 'Darae' or 'Gaetuli-Darae,' in the steppes of the Great Atlas [Mountains] and of the 'Melanogaetuli,' a black race resulting from the intermixture of the Gaetuli with their southern neighbors, the Nigritae." Henry Immanuel Smith, Course of Ancient Geography, (New York: D Appleton and Co) 1861, 309. Another text describes that this kingdom was perhaps first populated by the black Koushite, 'descendants of the Biblical Cushites, but were later invaded by Jewish Palestinian immigrants, intermarried, or were pushed aside, with some converting to Christianity. D. Jacque-Meunié, Le Maroc Saharien des Origines a 1670, Vol 1 (Paris: Librarie Klincksieck, 1982), 61.

75 “...les Gétules Autololes pourraient être les ancêtres des Guezoula et des Ilalene - Berbères qui occupent aujourd'hui l'Anti Atlas occidental et ses environs...Peut-être est-ce dans la même région que vivent ... aux temps de Polybe ou d'Agrippa ... les Gétules Dariens et les Éthiopiens Daratites qui pourraient être les uns et les autres les lointains ancêtres des gens du Dra parmi lesquels se côtoient des Blanc et des Noirs, sans beaucoup se mélanger entre eux en dépit d'une longue coexistence." D. Jacques-Meunié, Le Maroc Saharien des Origines a 1670 (Paris: Librarie Klincksiec, 1982), 167.
} 


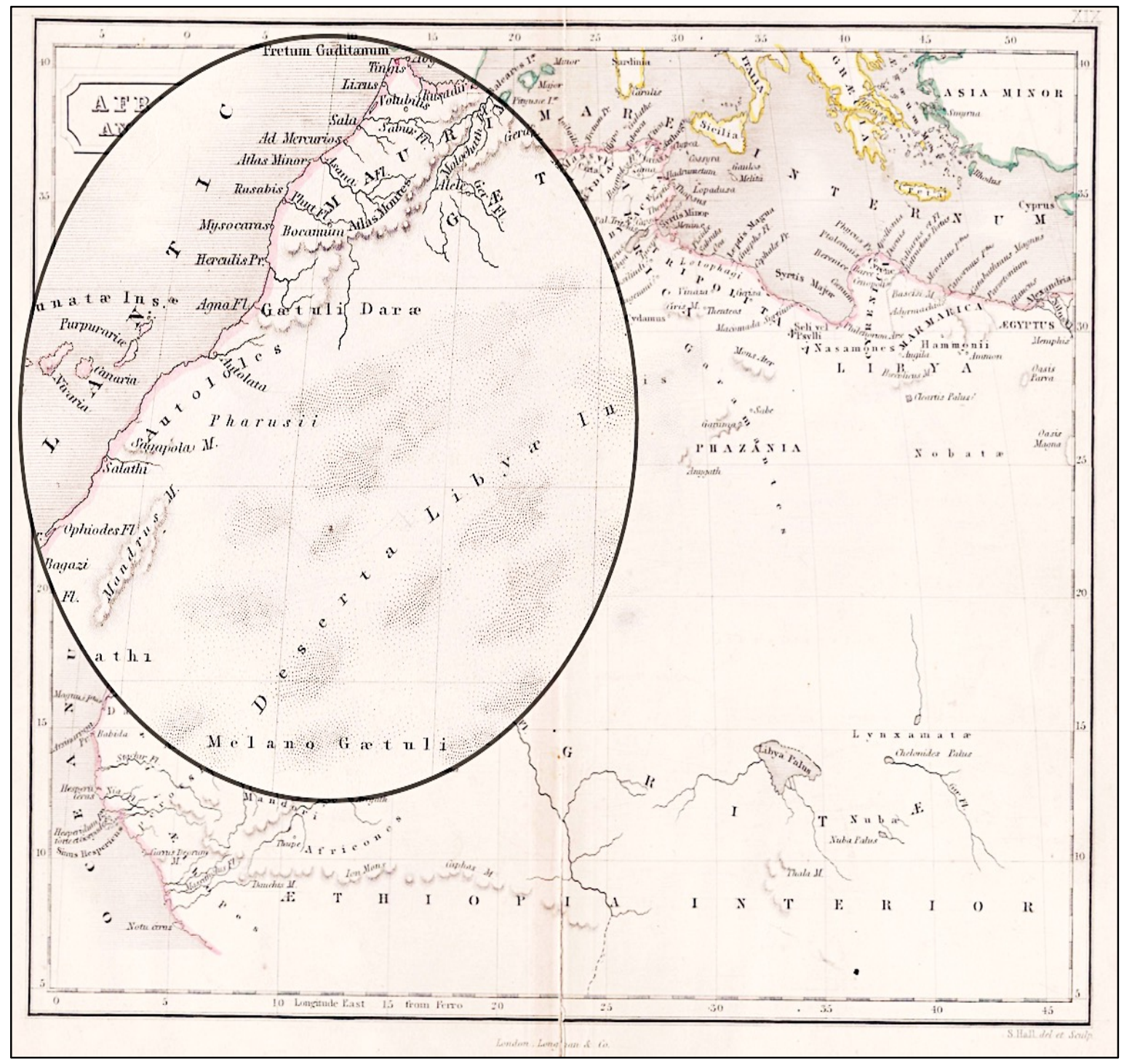

Map 3.1: African Antiqua Showing Ancient Groups in Northwest Africa ${ }^{76}$

289). The Berber tribes communicated "with at least four different alphabets found in Libyan inscriptions" stretching from the Atlantic coast to modern Libya and practiced ancestor worship, adopting pagan gods, such as the frequently mentioned Libyan god, Ammon (ibid., 289). A few authors (Smith 1854) and other ancient scholars, the most recognizable ethnic feature was skin color. The coastal cities along with the interior peripheral lands of the Gaetulian and Garamantes

\footnotetext{
${ }^{76}$ Map from Dr. Samuel Butler, “Africa Antiqua” (1838), An Atlas of Ancient Geography, (Philadelphia: Le and Blanchard, 1840).
} 
were associated with white or whiter skin color while those south of these Berber groups were described as black. For the most part, the essence of the Gaetulian Berber seems to indicate that they were a diverse set of tribes living and traveling across a vast North African landscape, using several scripts, and intermarrying with northern (whiter) and southern neighbors (Nigritae), adopting various gods.

Despite these obstacles of lineage, the Sahrawi concede that they are of mixed bloodBlack, Berber, and Arab. In fact, to the surprise of the author, in most interviews conducted in the Sahrawi camps outside Tindouf, Algeria, many POLSARIO representatives touched upon this mixed race idea matter-of-factly. In the words of Brooks, since "it is widely accepted that modern and historical Berber and proto-Berber populations ....are in large part descended from the prehistoric Saharan pastoralist groups" and "the cultural continuity evident between the archeological records of the central and western Sahara," extends to the Western Sahara, it gives the traditionally nomadic Sahrawi "a particular affinity with prehistoric pastoralists," countering the claims of a sedentary Moroccan society (Brooks 2007, 249). He also notes how "areas rich in in prehistoric burials" in the free zones of the Western Sahara have been used by POLISARIO fighters to bury their dead closely resembling the practices of the pre-historic period-reenforcing their identity with the land and their 'ancestors' (ibid., 250). Finally, in the search for examples of such primordial connections, there is evidence (although small) that the Gaetulians were the ancestors to a group called the Gudala. Camps wrote that "[i]t seems that the descendants of the Gétules [Gaetulians] are found in Guedala - also called Godula and Guezzala — great Sanhadja confederation in which the reformist movement arose of the Almoravids who were to conquer Morocco and create an empire stretching from Senegal to Ebro" (Camps, s.v., "Les

Gétules," https://www.clio.fr/BIBLIOTHEQUE/les getules guerriers nomades dans 1 africa romaine.as 
p\#biblio ). Still, these statements are based on speculation and they assume that for almost 2500 years (500 BCE - $2000 \mathrm{AD})$, these tribes have remained in the same location and of pure blood. ${ }^{77}$

The idea behind all of this history is to give the reader a unique perspective on the patterns of migration and cycles of invasion that characterized North Africa, specifically the area covering Mauritania, Western Sahara, and Morocco, including parts of southeast and southern Algeria. In order to extract the origins of the Sahrawi from the ancient past, the process necessitates visiting several periods of demographic change due to cyclical power structures and climate. It also demonstrates how Berber society had become diffuse as they migrated farther south. This pattern continued in the period leading up to the seventh century Arab invasions. The previous section ended with the mention of the Gaetulian-Berbers because they have been regarded as the most direct ancestors to Sahrawi identity. However, as these Gaetulians absorbed tribes and then sub-divided into others, a pattern of tribal diversification persisted. This pattern of change hinders the search for a group, tribe, or socio-political entity that can be tied to the modern Sahrawi. The following section details further difficulties.

Sanhaja Berber and Early Islamic Dynastic Rule — From the Fourth through the Eleventh Century

Three huge confederations of Gaetulian-Berber tribes came to dominate the Maghrib in the first centuries AD: The Sanhaja, Masmuda, and Zenata (Mercer 1976a, 499). According to Pazzanita, the Sanhaja Berbers are the primary ancestors of the Sahrawi and therefore the study will focus on tracing their descendants (Pazzanita 2006, 383). They are the forebears of the Berber people of

\footnotetext{
${ }^{77}$ Another problem lies with the labeling of these tribes. Norris asserts that two different tribes of similar name existed, the Gudula and Gazula. He mentions that the ancient Arabic texts confuse both. He distinguishes between the two, but only nominally, by implying that both survive today, with the Gazula inhabiting "the region between the Wad Nun and the Anti-Atlas in Morocco" and the Gudala, are "the most westerly and southerly of the mulaththamun [of the veil] Sanhaja in the Western Sahara." H. T. Norris, The Arab Conquest of the Arab Western Sahara (Harlow [Essex], UK: Longman and Librarie du Liban, 1986), 245-246.
} 
the Rif $^{78}$ and the Middle Atlas of Morocco, the Kabyles of Algeria and the Tuaregs of Mali, Algeria, and Niger. The Sanhaja (also known as the Zenaga or Azenaya/Azenaga) held and came to dominate the triangular desert area of the Western Sahara-from the Moroccan Sous, "the Trarza, now west Mauritania" to Timbuktu, Mali-between 50 BCE and 400 AD (Mercer 1976a, 499). They were originally an agricultural group "who were forced by the encroaching desert tobecome nomadic, warlike, caravan raiders" (Munene 2010, 73). These Berbers became powerful through their control of the trans-Saharan trade routes that extended south to Aoudaghost (modern Tedgadawast, Mauritania) through the collection of taxes and tribute, and "acting as paid guides and sentinels" (Page 2001,187). Their 'capital' seems to have been the city of Aoudaghost (or Awdahgast), which was a flourishing oasis located at the south-western end of the caravan trade routes used by the nomadic tribes of the Sahara.

At the same time, the Islamized Berbers began to permeate the caravan routes of the Sahara and spread Islam farther south and west to modern Mali. Between the first and eighth centuries, the primarily pastoral, nomadic and semi-nomadic, 'white' Sanhaja Berbers controlled the northwest region of Africa and by the eighth century had converted to Islam only superficially. They came to be characterized by resistance to control, but were confined to the north by their Berber rivals, the Zenata ${ }^{79}$, and the black Soninke people of the Ghanian Empire ${ }^{80}$

\footnotetext{
${ }^{78}$ This "geographical notion refers to the northern zone of Morocco formerly under Spanish and international control." People of the Rif region recognize three main confederations as well as territorial divisions: Rif, Ghommara, and Sanhaja." Ilahiane, Historical Dictionary of the Berbers [Imazighen], s.v., "Rif," 106.

${ }^{79}$ The Zenata were a rival Berber group that contested the domination of the Sanhaja. At one point they had pushed the Sanhaja "out of the Oued Draa" and Tafilalet and "came into control of the north-south caravan routes," restricting the free movement of the Sanhaja between the Sahara and the Atlas Mountains. Pazzanita, s.v., "Sanhaja," 2006, 383-384.

${ }^{80}$ The Kingdom of Ghana was composed of Soninke and Zenata Berbers and located in modern-day southern Mauritania and northern Mali. In 990 AD, it recaptured Aoudaghost (a city that became a critical trading center in the Ghanaian kingdom) from the Sanhaja Berbers.
} 


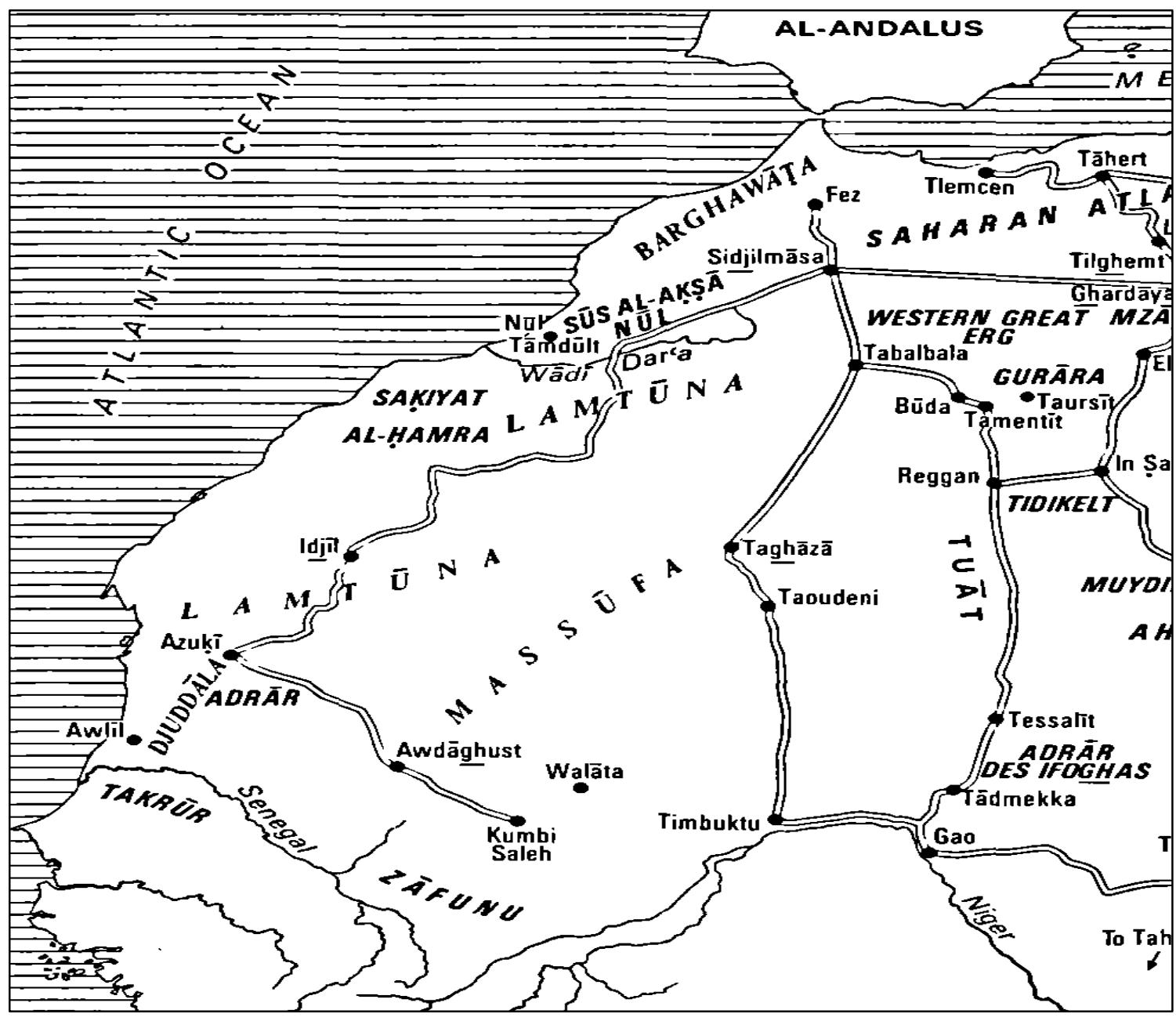

Map 3.2: Northwest Sahara ${ }^{81}$

to the South (Munene 2010, 73). The Zenata pushed the Sanhaja Lamtuna ${ }^{82}$ Berber tribes to Atari in the Adrar Mountains (modern Mauritania) and away from the Oued (River) Dra'a and Tafilalet (now present-day Morocco) (Pazzanita 2006, 383-84). Mercer states that the first Arab wave did not directly penetrate the desert and the Berbers themselves, from the east, spread Islam south and to the west across much of North Africa (Mercer 1976b, 72). Perhaps the first to arrive

\footnotetext{
${ }^{81}$ Map adapted from T. Lewicki, "The Role of Sahara and Saharians in their Relationships between North and South," in General History of Africa III: Africa from the Seventh to the Eleventh Century, 3rd edited by M. El-Fasi and I. Hrbek (Berkeley: University of California Press,1988), 279.

${ }^{82}$ Other spellings include Lemtuna or Lemtouna. Lamtuna was chosen to eliminate confusion from Lemta sub-tribe.
} 
with his Arab armies, Ogba (or Okba) Ibn Nafi, governor of the province of Ifriqiya and a caliph from Damascus, arrived in the Sous "as far as the sources of the Seguiet el Hamra" in 681 (Rézette 1975, 37). However, despite the wave of Arab Muslims that engulfed the whole of North Africa, the Berbers resisted. If there were any conversions, they were nominal at best, even among the Sanhaja ( $7^{\text {th }}$ through $9^{\text {th }}$ centuries). The Arabs designated the Sanhaja first as anbiya, but that was later changed to Sanhaja in the tenth century (Page 2001, 187). By the ninth century, three of the four leading Sanhaja tribes in the western Sahara were the Lamtuna, Massufa ${ }^{83}$, and the Guddala ${ }^{84}$ (see map 3.2), who had "inhabited the Sahara from Mauretania to Hoggar and to the south as far as the Sudan... were joined loosely in a confederacy" (Abun-Nasr 1971, 92). D'Almonte wrote that among these several fracciones (fractions), the Lamtuna fraction (or subtribe) was not only the most powerful and most important of the Sanhaja tribes but had actually peopled the Oued Nun $^{85}$ (Nun River) Valley (which lies north of 'Wadi Dar'a in Map 3.2) (D'Almonte 1914, 150). By 990, the Sanhaja had lost their 'capital' to the Soninke. Pressure from the Ghanian Empire, the Arab north, infighting between the Lamtuna and Guddala, two powerful tribes, had debilitated their once formidable power.

Anti-authoritarian aversion to royal or sovereign control became a more salient characteristic of the Sanhaja Berber in the Western Saharan regions. The Arab conquests of the Maghrib did not completely eradicate the strong sense of ethnic identity among the Berbers. Rezétte writes that the although the Romans had left 'frontiers' with their 'limes, ${ }^{, 86}$ "true occupation of the country by Arab conquerors who settled in with their families, only dates from

\footnotetext{
${ }^{83}$ Other spellings include Messoufa.

${ }^{84}$ Other spellings include Gadala or Juddala.

${ }^{85}$ Translated from the Spanish, “Son las tribus que actualmente pueblan el Uad Nun,” Enrique D'Almonte, Ensayo de una Breve Descripción del Sáhara Español, (Madrid: Patronato de Huérfanes de Intendencia é Intervención Militares, 1914) 160. This river is located in present-day Morocco.

${ }^{86}$ The 'Roman Limes' represented the borderline of the Roman Empire at its greatest extent in the 2nd century AD. UNESCO, Frontiers of the Roman Empire, accessed October 15, 2014, http://whc.unesco.org/en/list/430.
} 
the arrival of the Hilalian Bedouins beginning with the XIth century... [and was] bounded by the Bou Regreg River which empties in to the Atlantic between Rabat and Salé, was for long a real frontier. Beyond it, the country becomes empty" (Rezétte 1975, 37). The Arab march into North Africa only superficially converted the indigenous population. Many of the inhabitants fled to the hills and left the settled countryside. According to Monès, this was true, but later, many Berbers willingly accepted Islam because of its attractive message (Monès 1988, 243). Several sources reveal that although Islam was accepted as the new religion, many of those converted males would be conscripted to the Arab armies in their eventual domination of the entire Maghrib. However, harsher Arab policies toward the Berber were met with strong resistance. The struggle was based not on religion, but on the Ummayyad administration of the Berber communities and their complaints of inequality and discrimination. Grievances were also voiced by those Berber allies that had cooperated with the Arab armies: especially Arab 'ungratefulness' in the aiding and capture of the Iberian Peninsula (Monès 1988, 244; Abu-Nasr, 1971, 10).

There has been an immense amount of pressure attempting to establish Sahrawi lineage to the Berber people. Far from being descendants of a pure line of people, specifically in the Western Sahara, evidence shows the modern Sahrawi are quite the opposite. In fact, if a strict primordial explanation of nation were to be followed here, one would have to find genealogical (DNA) links, however small (qualitatively or quantitatively). These links should establish a historical thread that stretches back to the Bafour. For example, figure 3.3 above depicts a possible genealogical tree for the Sahrawi through the ninth and tenth centuries AD. However, based on the evidence and literature in this study, including absorption by manner of war, slavery, intermarriage, and nomadic transhumance, the linkages to the past are subjective and open to breakages in the genealogical line. 
Figure 3.3: A Possible Sahrawi Genealogical Tree ${ }^{87}$

${ }^{87}$ In reality, the Western Gaetulian Berbers were comprised of more than three tribes pictured above. They were a diverse set of independent tribes outside the control of the more agricultural, sedentary, coastal, North African Mauretanian and Numidian Kingdoms that included the Awarba, Berghwata, Houra, Kutama, Masmouda, Sanhaja, and the Zenata. 
For instance, beginning with the Bafour, the scholarly consensus has determined that they settled in North Africa but there is no agreement about where they came from. In fact, most of the scholarship tends to point to the arrival of different sets of Neolithic Berbers from all directions into North Africa, endangering the hope of a pure continuous connection to the Lybico-Berber. Second, the Berbers seem to be an amalgam of confederate tribes that stretched all along North Africa. The semi-nomadic to nomadic lifestyle based on the prehistoric rock art found scattered in and around the Sahara is very similar and points to parallel cultural features (horse rearing, cattle herding, ancestor worship, and warrior-like depictions). Still, ancient historians and modern scholars of today agree the Berbers were composed of dozens of tribes that spoke several dialects and wrote in at least four different scripts. Some built agricultural kingdoms along the coast while others preferred to roam the interior. Still other confederations of tribes had a close relationship with the Carthaginian and later Roman Empire, while others chose to remain aloof or rebel against their authority.

Third, further southwest along the coastline, Gaetulian Berber tribes of the Western Sahara "were independent and had the authority to make territorial decisions" (Danver 2015, 643). Thus, despite a narrower regional scope as the study moves forward, the 'bloodlines' are so mixed with disparate tribal history that it is nearly impossible to develop a formative line of descent to the Sanhaja. Fourth, the Sanhaja historically begin as a mixed collective from among several tribes (see footnote 61). Any one of these Sanhaja tribes could be a genetic ancestor to the Sahrawi but more anthropological research needs to be undertaken. Thus, the primordial approach in this case runs into a huge ontological obstacle. It is difficult to hold to the argument, at this point, that the Sahrawi are direct descendants of the Bafour, the Lybico-Berber, Gaetulian, or even the Sanhaja Berber. 


\section{The Great Berber Dynasties - From the Eleventh to Thirteenth Centuries}

The eleventh and twelfth centuries saw the development of two of the Berber's greatest dynasties, the Almoravid [ $\approx 1061 / 62-1147]^{88}$ and Almohad [1147-1269]. At their height, they encompassed most of the Maghrib, as far East as Tripoli, northward to southern Spain and the Balearic Islands, and deep into the southwest commercial routes of Niger and Mauritania, including the Western Sahara. The Almoravids, a mostly Lamtuna Berber-speaking minority that led a dynasty of majority Arabs could have been forerunners to the modern Sahrawi. In 1041-42, Yahya Ibn Ibrahim, chief of the Guddala tribe, on his return from Mecca, lamented at the poor observance of Islam among the Sanhaja Berbers, and invited "a fierce and austere preacher," Abdullah Ibn Yacin, a Sanhaja of the Jazula tribe, to evangelize the people (Pazzanita 2006, 20). Ibn Ibrahim had hoped that this 'pure' form of Islam would improve the fortunes of the inobservant Sanhaja. The Guddala (sub-tribe of the Sanhaja) rejected Ibn Yacin's message and expelled him. However, he traveled with a handful of armed disciples to establish a ribat ${ }^{89}$ in northern Mauritania (see Map 3.4). Initially, his following grew among the Saharan nomads and may have numbered from one to three thousand. Ibn Yacin's followers were called al-Murabitun ${ }^{90}$ (“those of the ribat"),

\footnotetext{
${ }^{88}$ Dates vary as to the beginning of their dynastic rule. Qantara-med.org states 1056; Ilahiane begins with founding of Marrakesh but in 1061; Historyworld.net posts 1062; The Encyclopedia Britannica establishes a start date upon the establishment of Marrakesh as well but in 1062; The author will suggest a general consensus of 1061-1062 based on the Britannica (Vol 1, 15 ${ }^{\text {th }}$ Ed.) and Ludwig W. Adamec, Historical Dictionary of Islam, s.v., 'Almoravid,' (Lanham, MD: Scarecrow Press, 2001), 43.

${ }^{89}$ Ribat has come to mean either 'fortified convent,' 'religious retreat,' or 'military fortress.' Most scholars tend to agree that it was a term used for denoting religious fortress. See Pazzanita 2006, 20; Rézette 1975, 40; Abun-Nasr 1971, 95; Mercer 1976b, 72.

${ }^{90}$ Al-Murabitun, which may also be stated as al-Murabitin and translated as 'Those Dwelling in Frontier Fortresses', is the Arabic plural form of al-murabit, which means an 'inmate' of the ribat. Encyclopedia Britannica, 10, 15th ed., s.v., "Almoravids."
} 


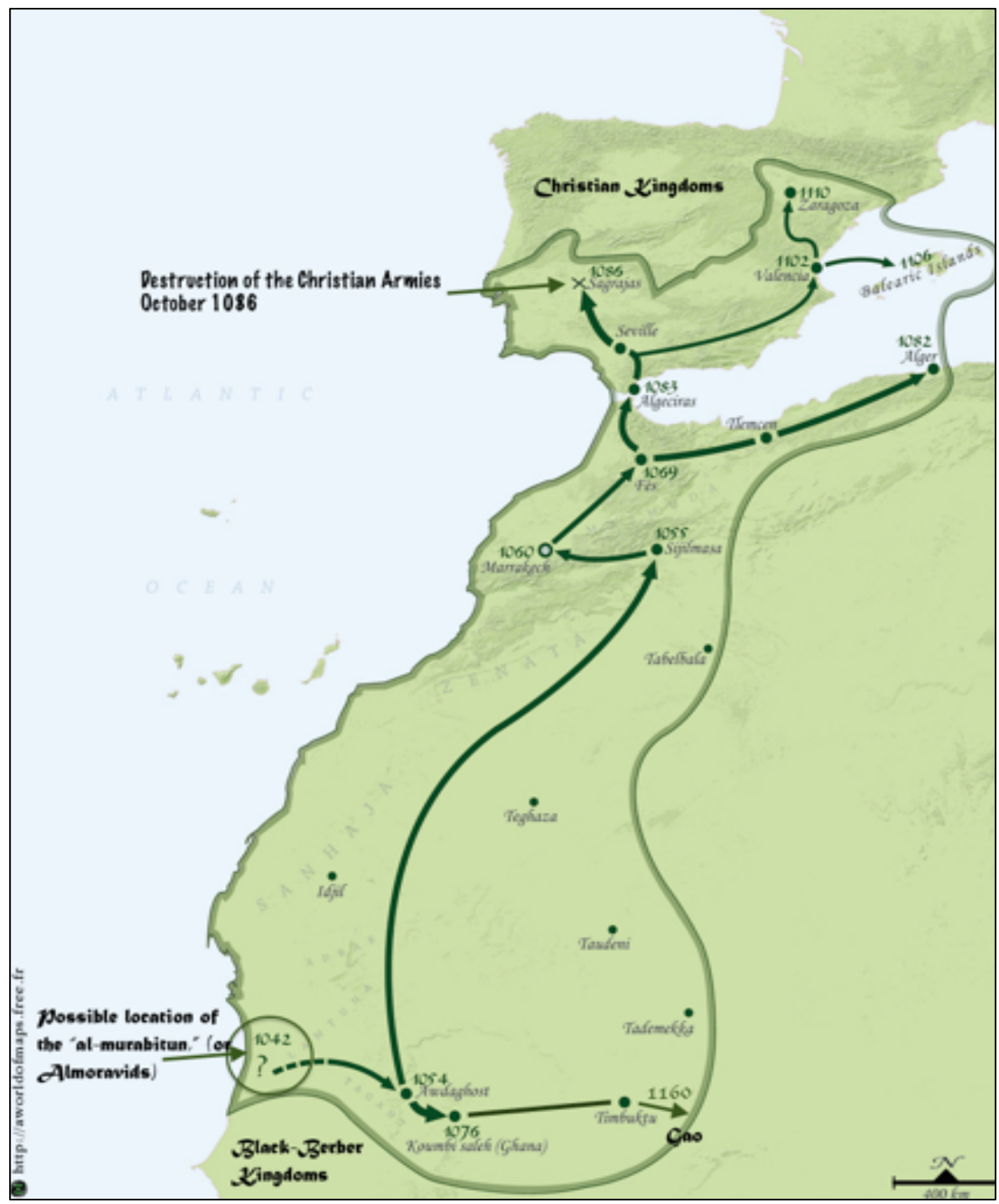

Map 3.4: The Almoravid Empire and Environs 91

${ }^{91}$ Map adapted and translated from the French by author. "The Empire of the Two Shores: The Conquests of the Almoravids until their Apogee,” http://aworldofmaps.free.fr/, 11 Aug 2009, accessed July 28, 2016, http://aworldofmaps.free.fr/fr/?showimage=32. 
from where the Spanish corruption 'Almoravides' ${ }^{92}$ originates. Eventually, the Murabitun or Almoravids came to dominate the southwestern Sahara and subject the Guddala, the Lamtuna, and the Massufa - all tribes that form part of the Sanhaja Berbers - to their strict form of Sunni Malekite Islam.

It is at this juncture that an interesting socio-political divergence of Sanhaja history takes place. Ibn Yacin, now allied with Yayha Ibin 'Umar, succeeding the deceased Ibn Ibrahim as head of the Lamtuna, led the newly militarized Sanhaja and indoctrinated the rest of the regional tribes under the Almoravid umbrella. Circa 1043, two militant Sanhaja streams-north and south-developed as an outgrowth of its strength and extended from its 'base' in southern Mauritania (see map 3.4 above). Abu Bakr Ibn 'Umar (who assumed control after his brother Yahya Ibn Umar perished in battle) defeat the Ghana Empire," take present-day provinces of Morocco, western Algeria, and "reunify Muslim Spain" (Pazzanita 2006, 384). According to Mercer, the southern militant stream descended as far south as the Senegal until the death of the Lamtuna Emir Abu Bakr Ibn ‘Umar in 1087. Under Abu Bakr, the ‘southern' Sanhaja had chosen his cousin, Yusuf Ibn Tashfin, to take control of the northern force while he ventured south to quell the unrest among the Sanhaja. This period initiated the Almoravid ${ }^{93}$ Dynasty (Mercer 1976, 499). The 'people of the ribat' used a more austere and "radical form of Islam to motivate the Berbers and consolidated Islam (only as an elite religion; the masses remained animist), moved civilizational focus south, which came "to evolve into the Mali Empire of the mid-thirteenth century, and [shifted] trans-Sahara trade...eastwards to routes, from Timbuctoo and Gao, through more stable zones" (Mercer 1976b, 73).

\footnotetext{
92 Almoravid is the transcription of the Arabic al-murabitun, inhabitants of a ribat, a kind of monastery. Abdallah Laroui, The History of the Maghrib: An Interpretive Essay, trans. Ralph Manheim (Princeton, NJ: Princeton University Press, 1977) 158.

93 The Almoravid or Al-Murabitun Dynasty, originating in the mid-eleventh century, encompassed the area of presentday Mauritania and parts of northern Western Sahara.
} 
The break among the Almoravids into north and south makes the search for origins of Sahrawi national identity much more difficult. First, the divergent Almoravid streams fracture considerably the number of Sanhaja Berber tribes that can be followed with any historical accuracy. Secondly, the nomadic nature of these tribes challenge the social and political scientist in associating a specific Saharan territory to a specific group. The only identifiable settled 'nations' in the proximity of the Western Sahara ${ }^{94}$ (apart from the Idrissid Dynasty) beginning in the tenth century were those, according to historical accounts, of the trading mecca and later principality of Sijilmasa, the Confederacy of Barghawata ${ }^{95}$, predominantly along the northwest Atlantic coast (modern Morocco) and then across the Sahara, approaching the mostly black Sahelian 'states' of the Takrur and Ghanaian Empire. The lack of research as a result of yet-to-bediscovered and untranslated literature, inaccessible manuscripts (due to conflict), and the harsh environment prevent proper study of the historical development of nation building in the Western Sahara. Finally, the only notion of a cohesive identity was tied to the tribe but there is no evidence before or as follows for a distinct 'Sahrawi' tribe.

\section{The Great Sanhaja Divide}

The northern portion of the Sanhaja, along with their marabout ${ }^{96}$ Islam, retook the important trading city of Sijilmasa (1056) from the restive Guddala, successfully founded the city of

\footnotetext{
94 The Idrisid Dynasty (789-921) was founded well north of modern Western Sahara in Fes (Morocco) by the Arab Idriss I. It did extend southward to the frontiers of the Barghawata tribal confederation but was only able to reach the pre-desert regions of Sijilmasa and possibly into the Sous River Valley. However, after Idriss II's death, the 'Kingdom' fragmented upon the division of its territories to his sons. The provinces never re-united and "caught in the crossfire of the conflict between the Fatimid and [Spanish] Umayyad Empires, their territories finally fell" to the Zenata. "The Umayyad victory over the last Idrisid, al-Hasan ibn Gannun...marked the definitive end of the dynasty in 974." Encyclopedia Britannica, 6, 15th ed., s.v., "Idrisid Dynasty,' 244; “The Idrisids (789-974)," Qantara: Mediterranean Heritage, accessed July 28, 2016, http:/www.qantara-med.org/qantara4/public/show document.php?do id=867., There are discrepancies over the end date of Idrisid dynastic rule.

95 John Ralph Willis, ed., Studies in West African Islamic History, Vol 1, The Cultivators of Islam, (New York: Routledge, 2012), 81.

${ }^{96}$ Marabout "is the name given, especially in North Africa, to a Muslim saint or to his descendants.” Eds., H.A.R. Gibb and J. H. Kramers, Shorter Encyclopedia of Islam, s.v., 'marabout,' (Ithaca, NY: Cornell University Press, 1965), 325.
} 
Marrakesh (1062), captured Fes in 1069, and established the kingdom of Morocco. Ibn Tashfin had begun construction of the new capital of Morocco Marrakesh (1070), which would become one of the most beautiful cities in all of Morocco. By 1082, the northern Almoravid forces had taken control of northern Morocco and northwestern Algeria (as far as Algiers). The northern parts of the Sanhaja Berber-led Almoravid Dynasty were to emulate Andalusian civilization in culture-including art, architecture, and construction of buildings and monuments. These developments were supported by the resources of gold found in the southern regions of Sanhajadominated Senegal and the western Niger. Still, the division, between the northern and southern areas of the Almoravid Dynasty remained due to the vast desert landmass of the Sahara. These northern Sanhaja were able to defend the region from the Eastern Fatimites, Hilalian Bedouin, and the Zenata (another sub-tribe of Sanhaja) who were pushed north earlier by the southern 'desert Sanhajas.'

These 'desert' or southern Sanhaja merit further historical detail because geographically they may offer a connection to the modern Sahrawi. The southern portion was beset by 'internecine warfare' and preferred to remain independent-maintaining traditional ways of living (Pazzanita 2006, 384). Despite there being Sanhaja confederations, not all were under an overriding, governing entity. Moreover, this becomes the constant dynamic among the tribes - a fluctuation of loyalties and tribal animosities. Even among the ruling elite, certain distinctions take place. For example, when Abu Bakr, returns from the south after defeating the Soninké (Ghana) to take his place as ruler of the northern Almoravids, he is told to "return to the desert," after negotiating with his cousin via enticements and favors. Pazzanita comments that Abu Bakr was then detached from the Almoravid's northern branch that conquered and settled in present-day Morocco and southern Spain (Pazzanita 2006, 384). Several authors noted that there was a division, not based on any cultural or ethnic separateness but on the route of conquest and trade. For example, Mercer briefly states that "the long-established Sahara crossing had been 
Sijilmasa—Tindouf-Kedia d'Ijil or the Ourane Desert—Aoudaghost but the troubles allowed Timbuctoo [sic] and Gao (see map 3.5 below) to continue to increase in importance, the former

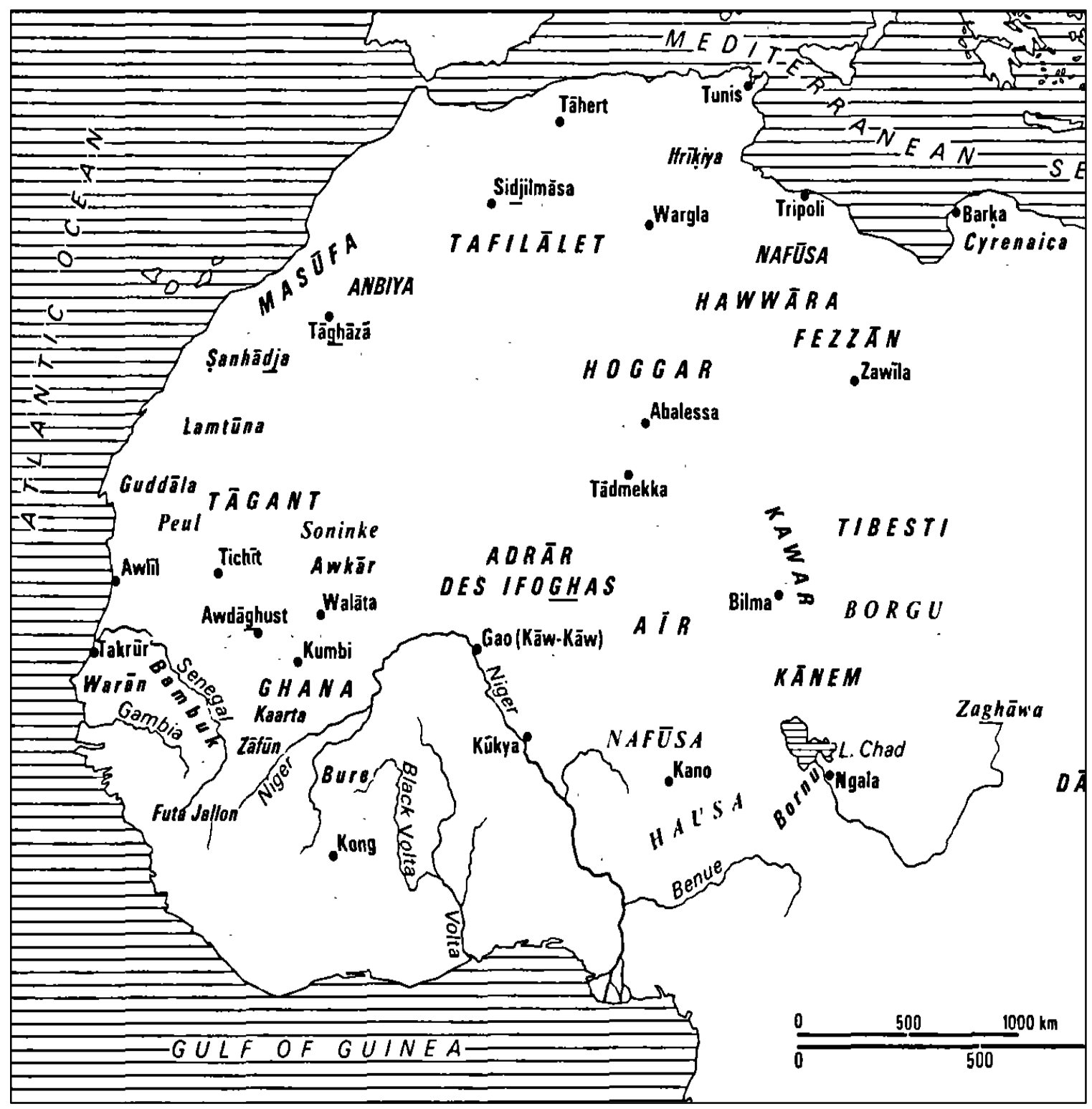

Map 3.5: West Africa in the Eleventh Century ${ }^{97}$

\footnotetext{
${ }^{97}$ Map adapted and taken from F. De Medeiros, "The Peoples of the Sudan: Population Movements" in General History of Africa III: Africa from the Seventh to the Eleventh Century, 3rd edited by M. El-Fasi and I. Hrbek (Berkeley: University of California Press,1988), 124.
} 
for those caravans still going to Morocco and the latter for Tripolitania. This isolated the [desert or southern] Sanhaja from the Maghreb” (Mercer 1976b, 74).

By 1147 , the Almoravid Dynasty was replaced by the Almohad ${ }^{98}$ Dynasty consisting of Masmuda Berbers of the High Atlas, controlling much of what is now the Kingdom of Morocco. The Almohad Dynasty arose in the Sous ${ }^{99}$ River Valley of southern Morocco. Mohamed Abu Abd'Allah Ibn Tumart defeated the Wali (governor) of Sous ${ }^{100}$ in 1132 and began to neutralize his surrounding Almoravid enemies. After the death of Ibn Tumart, 'Abdul-Mu'min Ibn 'Ali, a Berber from the Zenata tribe, became the successor to the Almohad movement and would later take the title of khalifa (caliph) and Amir al-Mu'minin (Prince of the believers). ${ }^{101}$ By March 1147, the Almohads were able to break the weakening northern Sanhaja capital of the Almoravids in Marrakesh. This conquest relegated the Sanhaja Berbers to the sands of the Sahara once again (Mercer 1976a, 500). The Almohads ordered a general massacre of the Lamtuna Berber (tribal power of the Almoravids) and declared Marrakesh (see map 3.6 below) as their new capital. A great number of the Lamtuna disappeared; some fled to Tuat (Algeria). Many of the Guddala (see map 3.5 above) were dispersed and ended up in the Sahara. "[T]he forced migration of the

\footnotetext{
98 The Al-Muhawiddun (Unitarians) or Almohad (Sp.) Dynasty (1113-1269) crushed the Almoravid Dynasty and for more than a century controlled an empire that encompassed the entire Maghreb (Morocco, Algeria, Tunisia, Libya, and al-Andalus (Islamic Spain). Ilahiane writes that, "by virtue of its religious ideology, military power and political organization, and economic and cultural development, the state still fires the imagination of contemporary attempts at North African unity.” Ilahiane, Historical Dictionary of the Berbers, s.v., "Almohads," 14.

${ }^{99}$ The Sous or Souss River valley (also known as the Sus in the Berber dialect of Tashelhiyt) of southern Morocco rises from several headstreams in the High Atlas Mountains and flows westward for 112 miles $(180 \mathrm{~km})$ to the Atlantic Ocean south of Agadir. Its alluvial basin, protected from the Sahara by the Anti-Atlas Mountains, has been one of Morocco's most fertile regions. Fruits, cotton, vegetables, sugar, and olives are grown, much of them for export. Encyclopedia Britannica, 11, 15 ${ }^{\text {th }}$ ed., s.v.,"Sous Wadi," (Chicago: Encyclopedia Britannica, 2010), 30.

${ }^{100}$ The Almoravid governor of Sous was Abu Bakr Ibn Muhammad al-Lamtuni.

${ }^{101}$ Amir al-mu'minin is also usually translated as "Commander of the Faithful" or Leader of the Faithful." "Abdul Mu'min was the first non-Arab to be given this title. Abun-Nasr, A History of the Maghrib, 111.
} 
nomadic Arabs of the southern Maghreb was almost complete"102 (D'Almonte 1914, 154). According to Pazzanita (2006, 384), it "left the desert southern peoples as the only surviving remnant of the once-flourishing [Almoravid] empire." Consequently, the Sahara Desert became not only an outlet for escape but also a refuge because of its inhospitable geographic nature. D'Almonte describes it well when he states that "the Great Desert and its steppe confines protected them from the fierce Almohads, whose voracity preferably attracted... on the other hand, the cities and the orchards situated between the Atlas and the Sierra Morena"103 (ibid.). D'Almonte also mentions, in his interviews with those elders of the Oulad-ed-Delim about the origins of their tribes, that "[t]he ferocity of the partisans of the Mehdi and Abdul-Mu'min had launched, to the Sahara, many Berbers and Arabs branded with fondness to the black banner of the Almoravids" (Ibid., 155). Many, according to the accounts in D'Almonte, were of the Guddala tribe, "(descendants of the ancient Gaetulians), and not many Arabs, more or less mixed with the Berbers, and native of Yemen (Qahtanites)"104 (ibid). From this short review of the Almoravids and Almohads, one finds that inter-tribal conflict and dynastic cleansing of 'odious' tribes only undermines the possible relationship theorized by claimants to a Sahrawi past. The Sanhaja tribes slowly began to change culturally — via Arabization of language and Islamization of religion — and purged demographically and historically through conquest. The early Gaetulian Berbers had been dispersed leaving only confederations of tribes along the northwestern Atlantic littoral and throughout the interior northwestern Sahara. Several groups, such as the Lamtuna,

\footnotetext{
102 Translated from the Spanish by the author: “...la forzosa emigración de los árabes nómadas del Mogreb meridional fué casi completa...” D’Almonte, Ensayo de una Breve Descripción del Sáhara Español, 154.

103 Translated from the Spanish by the author: “...el Gran Desierto y sus confines esteparios los reguardaron de los feroces Almohades, cuya voracidad atraían preferentemente, por otra parte, las ciudades y los vergeles situados entre el Atlas y la Sierra Morena." The Sierra Morena is a Spanish mountain range that generally marked the extent of the Almoravid reach into southern (Andalucian) Spain. Ibid.

${ }^{104}$ Translated from the Spanish by the author: “... (descendientes de los antiguos getulos), y no pocos árabes, más o menos mezclados con los berberiscos, y oriundos del Yemen (Kahhthaníes).” Ibid., 155.
} 


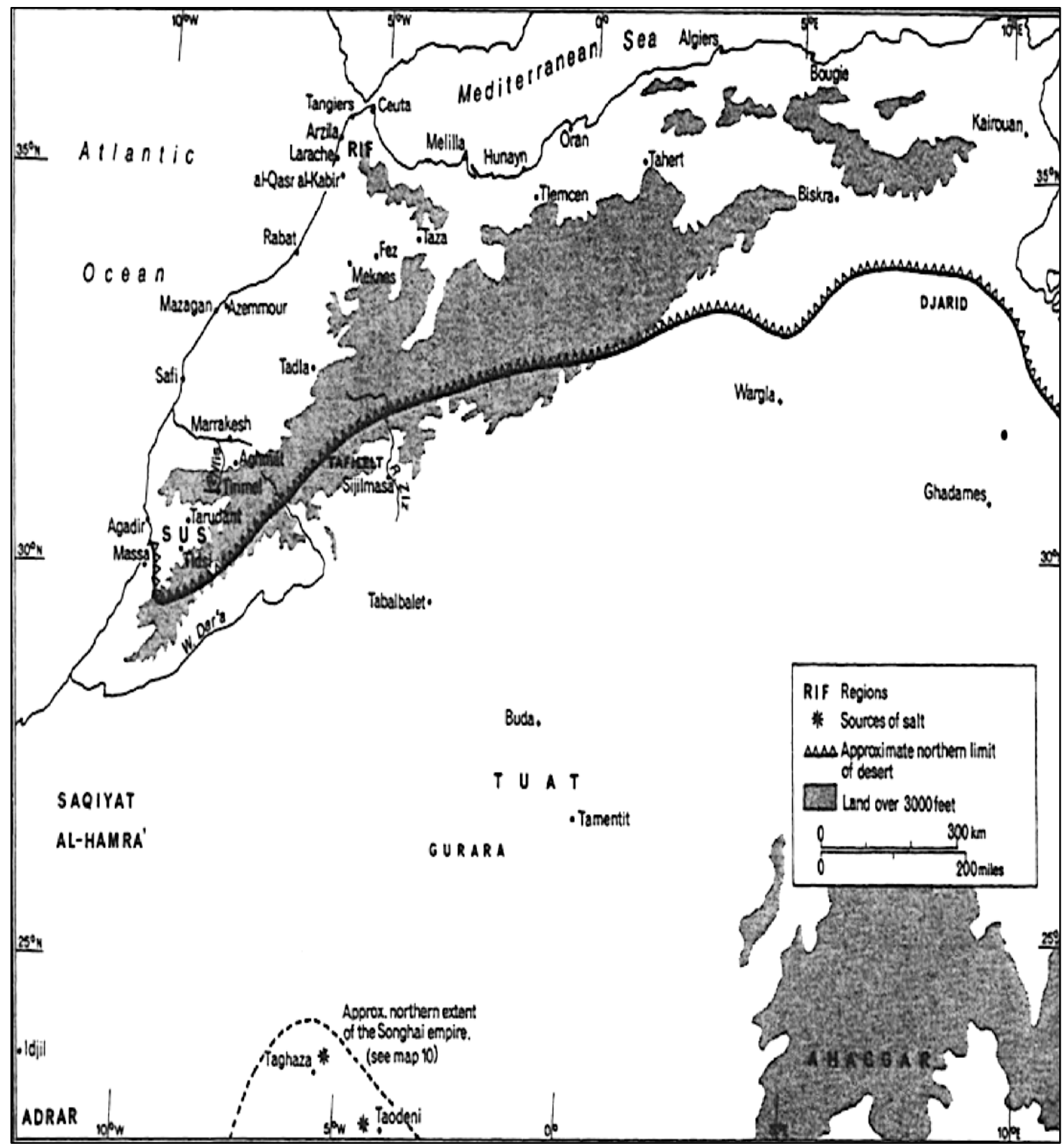

Map 3.6: The Western Maghrib and Northern Sahara ${ }^{105}$

Guddala, Arabs, even Blacks ${ }^{106}$ were killed, expelled, or fled farther south into the Sahara. These groups were displaced by Zenata and Masmuda Berbers, rival to the Sanhaja from the northeast

\footnotetext{
${ }^{105}$ Map from Roland Oliver, "Western Maghrib and the Sudan," in The Cambridge History of Africa 1050 to 1600 , Volume 3, Cambridge Histories Online (New York: Cambridge University Press, 2008), 332.
} 
of modern Morocco (the Rif, Fes, and Marrakesh). Thus, possible ancestral candidatessuch as the Lemtuna, Guddala, and various smaller groups of Sanhaja dispersed or were forced to migrate deeper into the Sahara (see map 3.5 above) as far as the Senegal River regions. As such, narrowing any one ancestral tribe or confederation of tribes to the Sahrawi remains elusive.

Arab Dominance and the First Europeans: Thirteenth to Sixteenth Centuries 'Almohadic' rule, as interpreted through their puritanical form of Islam, had already begun to divide both Berber and Arab, settled and nomadic people alike, including those of Sanhaja extract, from those city-dwellers who became allies of, and benefitted from, the Almohads. D'Almonte describes how, thereafter, the Maqil Arabs had begun to drive a different, more geographical, wedge between the Berbers of the Atlas Mountains and the Berbers of the Sahara. The Banu Maqil are important in this section of the study because they are considered the next promising tribal forefathers to the Sahrawi. The Maqil were an Arab Bedouin tribe whose origins were probably from Yemen. They reached the Oued Dra'a (W. Dar'a in Map 3.6 above) in 1281, assisted in the overthrow of the Almohads in 'Morocco,' and helped establish the Merinid Dynasty of the Zenata. Despite the aid, the Maqil were a warrior class that was a menace to the Merinids (and at times allies to Merinid adversaries). Moreover, several branches of the Banu Maqil fragmented even further and would become both allies and enemies of the Merinid, complicating the geo-political situation for the fledgling dynasty.

The newly found Merinid ${ }^{107}$ Dynasty (1248-1465) pushed the Banu Maqil southward toward the desert-dwelling Sanhaja Berbers (Pazzanita 2006, 385). Eventually, the Banu Maqil

\footnotetext{
106 "The Almoravids, and in particular their leader, Abu Bakr b. 'Umar, are credited by oral traditions in Mauritania with the final dispossession of the Blacks from their strongholds in the Sahara. In fact, the Almoravids' exploits marked a decisive state in a long process in which black sendentaries retreated south to the Sahel as the Berber nomads advanced." The Cambridge History of Africa, Vol 2, from c. 50 BCE -AD 1050 (New York: Cambridge University Press, 1978) 665.

107 The Merinid are descendants of the Banu Marin tribes.
} 
merged with and absorbed the Sanhaja Berbers. On many occasions, expeditions were mounted in order to push them southward and away from the (Moroccan) Sultanate. Another invasion from the east comprised of the Beni Hassan or Awlad Hassan, ${ }^{108}$ a branch of the Maqil Arabs, had arrived to support the Moroccan Zenata Berbers. They clashed with the Sanhaja in the south and southwestern Sahara. By the thirteenth century, the Beni Hassan had invaded the Oued Dra'a and Oued Noun regions, mixing with the Sanhaja Berber. Gradually, the Sanhaja began to disappear. Their language was replaced by the Hassaniya ${ }^{109}$ Arabic dialect. This migration gave rise to the Tekna tribes and the Oulad ed-Delim (one of the purest of Arab nomadic groups).

According to Norton, the Banu Maqil, wedged between the more southerly Berber Saharans and the northern Merinids based in Fes, Kingdom of Fes, "found the Sus [sic] to their liking" (Norton 1986, 174). In a very interesting comment taken from Ibn Khaldun in his History of the Berbers, Norton states that the Maqil "subdued" and levied taxes on the subject people in the Sous and the Valley of the Nun (ibid.). According to research conducted among the national archives in Madrid, the Sous River Valley and its adjacent Oued Dra'a Valley, along with the Atlantic coastal points from Santa Cruz to Cape Nun and further south to Sequiet el-Hamra, was an area of contention and little governmental structure for the next five hundred years. The Sahrawi nationalist movement argues that this area, the northern-most part of the Western Sahara, is not and has never been the domain of the Kingdom of Morocco. Thus, the Banu Maqil, independent of the Kingdom of Fes, began to establish its own governing entity through the collection of taxes. Laroui mentions that between the years of 1384 and 1411, the southern part of

\footnotetext{
108 The Beni Hassan (or Awlad Hassan or Banu Maqil) tribes plus the Banu Hilal migrated from Yemen westward. According to Pazzanita, the Beni Hassan was an Arab warrior caste, 385. These tribes, sent as a punishment from the Fatimid Caliphate in Egypt, were pushed westward and south into present-day Mauritania and the Western Sahara. Stephen Zunes and Jacob Mundy, Western Sahara and Conflict Irresolution (Syracuse: Syracuse University Press: 2012), 145 .

${ }^{109}$ Hassaniya is the Arabic dialect spoken by present-day Sahrawi, which originated from the Arab Bedouin tribes of the Beni Hassan and later became the dominant language in Northern Mali (Azawad), most of Mauritania, the Western Sahara, and parts of southern Morocco between the eleventh and fourteenth centuries.
} 
the Merinid Kingdom (Kingdom of Fes) "had declared its independence..." because "of the increasing power of the Ma'qil, "who had become the main power on the central Maghrib before extending their domination southward to the Western Sahara" (Laroui 1977, 231). In fact, in one instance in 1387, Ahmad al-Mustansir, when he recovered his throne from a rival Merinid vizier, "with the help of the Maqil who controlled the Sijilmasa region...rewarded the Maqils by allowing "them access to the Atlantic plains while leaving them their privileges in southern Morocco" (Laroui, 230).

These domestic squabbles, the rise of small fiefdoms, and the Banu Maqil encroachment diminished much of the power and influence of the Merinids. The Merinid 'Dynasty' was, in effect, of nominal influence in the region. The Christian princes of Iberia, aware of the situation in the Maghrib and the weakness of Fes, began their foray into North Africa, including the Western Sahara. For example, the Portuguese began to settle in the northern Maghrib in 1415 (Tangier) and by 1458 had conquered al-Qasr al-Kabir. Later in 1472, the Merinids of Fes were replaced by Muhammad al-Shaykh of the Banu Watta. Still, the power of the Wattasids (14721554), who had replaced the Merinids, "had never extended beyond northern Morocco" and that “in 1471 the Moroccan state, as founded by the Almoravids, ceased to exist" (Laroui 1977, 238). The Wattasids ruled Fez and some of its periphery through 1524. By then, however, the Portuguese (see map 3.7 below) had expanded along the Atlantic coast of 'Morocco' and established small forts or trading outposts in Santa Cruz do Cabo de Aguer or Agadir (1505), Safi (1508), Azemmour (1513), and Mazagan (1514, already a protectorate in 1486). By the beginning of the sixteenth century, Genoese, Spanish and specifically Portuguese traders had created several small points across the northern coast of Morocco, stretching from Ceuta to Santa Cruz de Aguer. Santa Cruz de Mar Pequeña (1476) was perhaps the furthest south of the coastal European outposts. Essentially, the Wattasid's "effective authority...was restricted to Fez and its environs. They had a limited control over the Atlantic plains, and it was only by force that they could exact 
some tribute from tribes of the Middle Atlas. Marrakesh was virtually autonomous, and the High Atlas, the Sus, and the pre-Saharan oases were completely outside their authority" (Levtzion 1977, 397).

Further south of the Sous and into the Sahara, the "northern section of the Sahara came increasingly under domination of Arab nomads. They imposed their 'protection' over the preSaharan oases and extracted tribute from the inhabitants and traders there" (ibid., 451). Oliver also reveals through Ibn Khaldun who commented that "some of the veiled Sanhaja of the southern Sahara were 'in subjection to the King of the Sudan, paid him tribute and were recruited to his armies' " (ibid, 381). In summary, by the time of the Wattasid Dynasty (from the geographic periphery of the Kingdom of Fes' dominions southwest across the Atlantic coastline to the Wolof Kingdom in present-day Senegal, inland east to the Adrar and returning north along the trade route to Sijilmasa, which had ceased to be the great trading hub), the Western Sahara was not governed by a single sovereign entity. Historical evidence demonstrates that acknowledgement or submission to any authority was divided among the several fiefdoms that sprang up when the Wolof, Mali, Songhai, and Wattasid rule weakened considerably in the sixteenth century. Moreover, these dynasties or empires hardly had any sort of control over the wandering, ill-governable, and desolate land-dwellers of the Western Sahara. It was only when a new Sharifian Dynasty, the Sa'adians, came to power in the Sous River Valley in 1524 (see on map 3.7 below referenced as "Principauté des Chorfa Saadiens" or the Principality of the Sharifian Sa'adians) that perhaps a more cohesive phase of nation-building began among the inhabitants of the Western Saharan region, though these people could hardly be identified as "Sahrawis." 


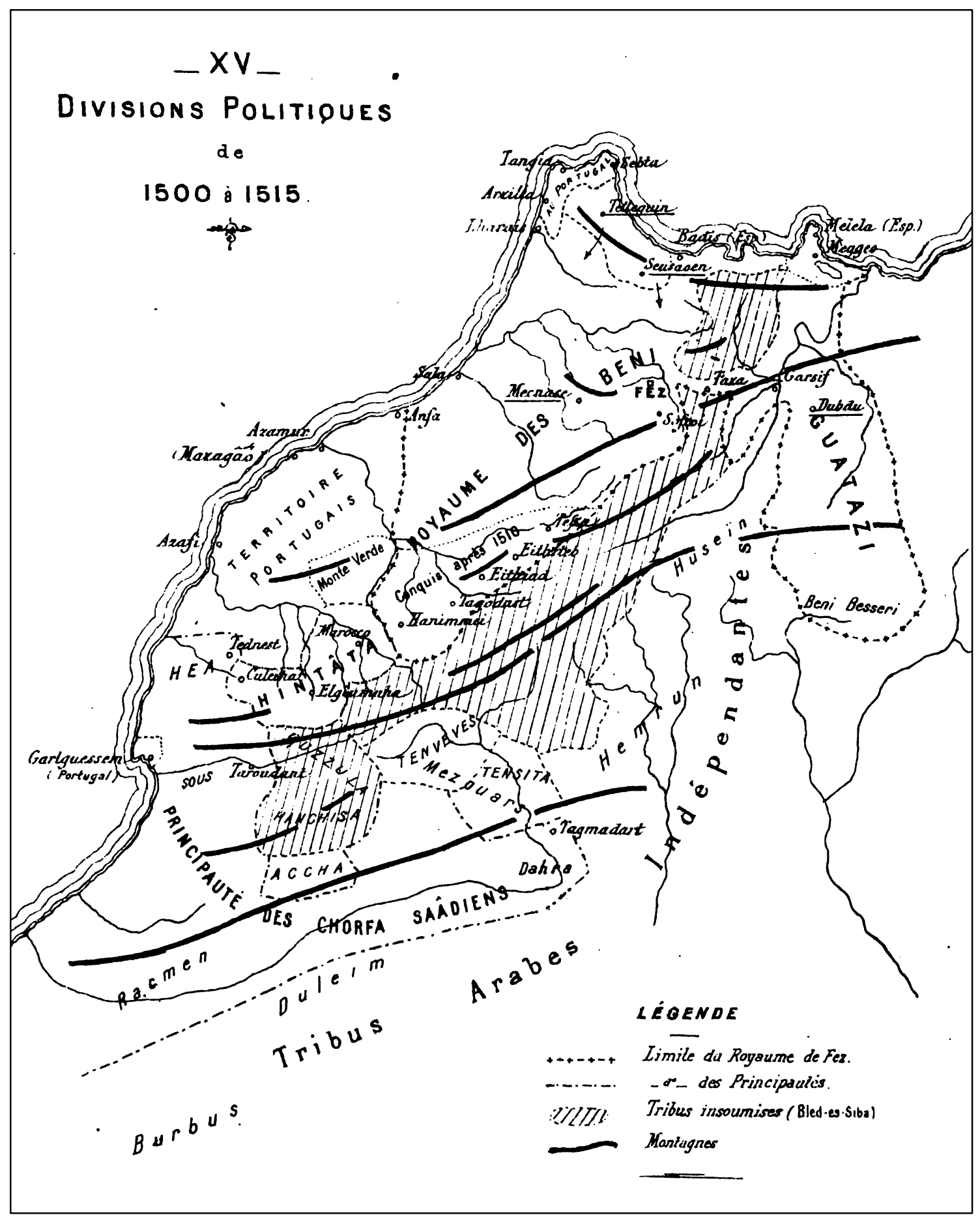

Map 3.7: Political Divisions from 1500 to 1515 of Morocco ${ }^{110}$

\footnotetext{
${ }^{110}$ Map adapted from Louis Massignon, "Le Maroc dans les Premières Années du XVI Siècle," Tableau Géographique d'Après Léon L'Africain. Mémoires des la Société Historiques Algérienne (Algiers: Adolphe Jourdan, 1906), 149.
} 


\section{Historical Analysis and Critique}

The essence of this section consisted in tracing Sahrawi national identity from its antiquity until the beginning of the sixteenth century. It highlighted the key events that characterized much of Sahrawi ancestry. The chronological detail, at times tedious, was necessary so as to place it in the context of the evolving dynamics of 'Sahrawi' identity. Thus, many details were included so the reader would understand why none of the above candidates met the test of "true" ancestry to the Sahrawi from antiquity through the beginning of the modern era. We can see that none could have begun to be considered a national group, and the origins of Sahrawi nationalism are much more modern. The following will summarize these results, and by concluding, aid the reader in understanding national identity through the example of the Sahrawi. This section began with a highlight of the ancient origins of the indigenous inhabitants of the Maghrib, specifically the Western Sahara. It has found that Sahrawi ancestry may not be traceable from deep in antiquity. Some of the problems encountered that could have provided some evidence for Sahrawi origins at this time: 1) There is scant history of human beings inhabiting the area now known as Western Sahara going back 10,000 years. 2) Many of the early inhabitants of the region, in North Africa, southern Europe, and the greater Mediterranean world, can all trace their beginning from Neolithic peoples; a problem that may deem DNA studies necessary but beyond the scope of this study; 2) It is a problem of infinite regress. At which historical point does one begin to study the national identity of any nation? Where does one begin to discuss that 'belonging' to a group of people, or attachment to the homeland or territory? 3) The nature of Sahrawi ancestry and of any study of nationhood will certainly come across the inevitable challenge of distinguishing between those of pure blood and those of mixed origins, but there was not enough stability in this region for any people to be considered of "pure blood" to evolve.

On the contrary, many scholars affirm the hybrid origins of the people of the Western Sahara. Many agree that present-day individuals who identify themselves as Sahrawi are 
primarily of Berber descent, though mixed with the Black nations of sub-Saharan Africa, and finally succumbed to the 'waves' of Arab tribes from the East by the end of the Middle Ages. For example, Mercer writes that the early roots of the Sahrawi are complex and are a result of: several hundred years of intermarriage, subjugation by 'foreign' rule, or self-rule via the early Berber or Arab dynasties, frequent migration patterns, and 'invasions' from those groups emerging from the eastern and southern Sahara. (Mercer 1976a, 498) Hodges describes the ancestors of the Sahrawi people as sub-groups "of the beidan, ${ }^{111}$ or 'Moors,' nomads of mixed Berber, Arab, and black African descent who now speak an Arabic dialect known as Hassaniya" (Hodges 1983, 74). He describes this fusion as a product of wars, and with Mercer, agrees it is also a result of subjugation, alliances, and intermarriage of Sanhaja Berbers, Bedouin Arabs, and black African slaves. Today, there is agreement among several sources that the most visible of the Sahrawi groups are the "Hassaniya-speaking people who claim membership among at least one of the social groupings found in and around the area now known as [the] Western Sahara" (Mundy and Zunes 2012, 140). Thus, an early indication of Sahrawi national identity is difficult to detect.

This mixture of "races" (Black, Arab, and Berber), perhaps not quite unique among the North African population, is central to perceived Sahrawi identity. Laroui writes "anthropological studies and archeological finds now tend to prove both the antiquity and diversity of the Maghribi population" (Laroui 1977, 17). Present scholarship is inclined to recognize "a diversity of origins and of the essentially fragmented and passive character of the Maghribi past" (Ibid., 19). In the words of Gabriel Camps, the Maghrib was "a transitional region without distinct characteristics of

\footnotetext{
${ }^{111}$ Beidan or bidan (bidthan) is "the name used by the Saharan Moors, both Arab and Berber speakers in order to distinguish themselves from the negroes. The term, meaning 'the whites,' is found in quite early writings. According to La Courbe (1685), "The Senegal separates the Azoaghes [Zenagah] Moors or Bazanez [Bidan], from the Blacks; so that on one side of the river are Moors, rather white than black; and on the other, men perfectly black." Norris, The Arab Conquest of the Arab Western Sahara, 245.
} 
its own" 112 (ibid., 20). If there were an argument for a more homogeneous population, the case may be found much later in North African history, beyond the new 'Christian' millennium. Yet, Hodges has made a more modern socio-cultural distinction between the nomadic and sedentary Sahrawi. He writes that even today, among the Sahrawi, there are Arabophone nomads, Berber Tuareg nomads (east), black African farmers (south), and semi-nomadic or sedentary Berbers of the Sous River Valley and Anti-Atlas region, north of the Sous (Hodges 1983, 74).

A few authors have argued that there is a case for a sense of homogeneity found in the Sahrawi past. For instance, Ghirelli ${ }^{113}$ believes that the apparent homogeneity of the remaining Sanhaja Berber may have been due to the (a) geographic protection afforded to them by the Sahara Desert to the south, the Mediterranean and the Atlantic Sea to the north and west of the Maghrib. Secondly, the (b) nomadic lifestyle that is attributed to the ancestors of the Sahrawi remained intact despite a history of intermarriage and constant fighting among themselves and with invaders. This may be the result of a unique lifestyle that adapts to the harsh, desert environment. However, geographic and nomadic factors do not provide evidence of socio-cultural homogeneity. Nomadism may be a lifestyle marker for a certain collectivity, and geography may demarcate the boundaries of a group, but it certainly does not indicate that all of those characterized by these cultural markers are of the same ethnie, or nation. Certainly, the settled population may better candidates for the descendants of the Western Saharan but there is difficulty in choosing the correct genealogical group. These factors may indicate that several mixes of groups, relegated to the harsh landscape over the centuries, were forced to cooperate in order to survive the desert.

Third, another argument suggests that Islam may have forged Sanhaja Berber homogenization. Although the overwhelming majority of the population came to adopt the

${ }^{112}$ Gabriel Camps, "Les Traces D’un Age du Bronze en Afrique du Nord," La Revue Africaine, Alger, 1er et 2e trim, 1960, 31-56 quoted in Laroui, The History of the Maghrib, 19.

${ }^{113}$ Exact period for his Ghirelli's comment not clear. 
Muslim practice, the Sanhaja have characteristically, jealously protected their culture from outsiders. In fact, many of the Sanhaja Berber only nominally converted, nominally claiming to be Muslim but retaining pre-Islamic, pagan beliefs and practices. Moreover, the Berbers developed particular Islamic sects that arose to challenge the authority of the Baghdad Caliphate. Recent research about the area has uncovered struggles between tribes and with other foreign invaders over the control of the prized Trans-Saharan trade routes supplying gold and silver (in coins) among other valuable items as well as goods for market. The preponderance of tribal or sub-divisional (fractional) group communities supported a less cohesive, more fractured society that rarely acknowledged a sovereign power, and at times preferred to remain aloof in the desert.

This section's efforts focused on evaluating a series of claims about different groups as the "true" ancestors of the modern Sahrawi. Was there a beginning? This is the second challenge. The first was to determine at what point to begin tracing the origins of the Sahrawi. Perhaps another approach to the challenge would be to follow the socio-historical progress of the groups confined to the Western Sahara instead of searching for definitive origins. In these terms, the development of Sahrawi ethnic identity may be seen as a "layering" of generations and perhaps centuries of movement, division, and intermarriage. Their ethnic make-up consists of disparate tribal conglomerations and a propensity to absorb several different generations of other foreign groups (i.e., Carthaginians, Romans, and Arabs). Thus, the amalgamation of groups, early periods of migration, and continuous tribal division make it difficult to acknowledge a nationality based on a primordial approach. Yet, modern-day Sahrawi nationalism may provide us with an example of an evolved identity that may be attributable to primordial connections. Smith for example refers to a "collective cultural identity...not to a uniformity of elements over generations but to a sense of continuity on the part of successive generations of a given cultural unit of population" (Smith 1991, 25). 
Smith's re-formulated version of primordialism is called ethno-symbolism. Ethnosymbolists agree with post-modernists in "the importance of conceiving of nation as 'real' sociological communities" (Smith 2009, 13). Ethno-symbolists agree with modernists that nations "are conceived of as historical communities, embedded in specific historical and geocultural contexts" (Ibid., 14). In other words, the 'national' character and 'progression' of a community is open to formative historical assessment. It absorbs change and aids in explaining the development of a nation. This flexible version of primordialism allows for a variable nationbuilding process. Thus, it can help explain the amalgamated dynamic of Sahrawi national identity. Yet, ethno-symbolism "still regards ethnic identities and communities as crucial for the formation and the persistence of nations" (ibid., 21). It considers that "although nations may be partly forged by political institutions" or as "elite projects," they also necessitate "over the long term... ethno-cultural resources to create a solidary community" (Smith 1991, 21).

'Historical ethno-symbolism' tries to bridge primordialism to instrumentalism and constructivism. Instrumentalism can explain how each individual or small group of individuals gathered together their adherents to develop an ideology and then as a consequence, mobilized their followers to advance more regional ambitions_-establishing rule and dominance, political power. However, according to Robertson, constructivism combines both primordialist and instrumentalist perspectives and may be a more effective explanation. Despite ethno-symbolism incorporating the more post-modern theories of nationalism, it still begins with an ethnic base. Such an approach will encounter problems in trying to locate the origins of Sahrawi identity. This section has illustrated that even if allowances were to be made in order to highlight an ethnic sense of homogenization, it still would be challenging to pinpoint within this period of history. Constructivism, on the other hand, does not necessitate an ethnic starting point and may be able to better explain the slow progression of ideas producing a Sahrawi national identity in this historical segment. Constructivism, by its approach will absorb these historical events and will 
provide for a more comprehensive perspective of identity change. It also grants the possibility of an outright manufacture of nationhood by the elites or those who are vested with the power directing the population (ethnic entrepreneurs), a top-down view of forces that can give rise to national identity. It also consents to a criterion that establishes national identity among those links attached to 'natural' givens, including those ethnic symbols developing over time.

The primordialist approach is severely handicapped seeking the origins of Sahrawi identity in this period. The challenges of mixed races, diverse interaction, and distinguishing between sedentary or nomadic groups hinder primordialist arguments. If placed in an ethnosymbolic context, a primordialist approach may help argue for gradations of development. Yet, these still do not solidify an identity. Instrumentalist arguments are limited to arguments that include dynastical leaders. However, the Almoravid and Almohad dynasties were marred by divisions, both geographical and tribal, and finally falling, reducing their influence to a small segment of northern Morocco, leaving the rest of the Western Sahara region free. The constructivist would absorb the layering of qualities that developed over time, add the dynastic experiences of the region, and begin to create an identity; a proto-Sahrawi is being built upon these features of identity. Still, the third (constructivist) hypothesis cannot precisely state that the Sahrawi were born at this time.

This historical investigation suggests that an innate awareness, especially among a distinct group of people (sub-tribe, fraction or tribe, federation of tribes) that desires to consolidate and remain in one single area is difficult to ascertain because the expansionist and unifying aspirations were most commonly directed and controlled by elites. These elites usually had the support of clerics or fringe movements that co-opted the population of the immediate area. It is also very challenging to provide concrete evidence connecting present-day Sahrawi identity to Sanhaja Berber identity. As has been noted, as one reads this socio-historical account, the migratory patterns, infighting among local tribes, larger gradual incursions of foreign tribes- 
including Arabs from the East-subsequent intermarriages, death through loss of patronage (death of a leader) or extermination of one's people through loss in battle, and slavery, highlights the immense difficulty in forging a direct blood line or pattern of traditional ancestry. The premise "that nations were around from 'the first time' and were inherent in the human condition, if not in nature itself" (Smith 2009, 8) may, in fact, be true. It is not evident in the Sahrawi case. The question will continue to be when was the 'first time' for the Sahrawi? The answer may not be clear in this section. However, it may be that the development of the socio-historical character of the region may have been constructing Sahrawi identity all along. In this case, the results can only be historically measured much later in time. This leads to the next chapter, which will attempt to discover such an answer after 1524 . 


\section{SAHARAN IDENTITY: DYNASTIC OR TRIBAL (1524 - 1757)}

This section will focus on the roots of Sahrawi identity from the period beginning in 1524 until 1757. This period was not chosen arbitrarily. 1524 is the year Santa Cruz de Mar Pequeña ${ }^{114}$, the Portuguese trading outpost and small fort, was overrun by the Sa'adian Dynasty. 1757 was the year Mohammed Ben Abdellah al-Khatib, or Muhammad III, came to power in Morocco and achieved moderate stability after almost a quarter century of fraternal infighting for power. This section will continue the socio-historical analysis of the period in the western and southwestern Maghrib region (including Mauritania, Western Sahara proper, and Morocco). It will provide insight to claims of distinctiveness by the Sahrawi and their possible links to this historical period.

Here, the first hypothesis will be examined: that Sahrawi origins are rooted to a historical past but only to this period, instead of the previous era. Another hypothesis is derived from the constructivist approach: 1) the encroachment of colonial powers into west and northwestern Africa generated resistance from those long-since established inhabitants leading to a protonational identity (see map 4.1 below); or 2) a more organized political society among the Western Saharans developed because the sovereign entities ruling the area became stronger and expanded their territory. This chapter seeks evidence that sustains these arguments: The origins of Sahrawi national identity was due to the developments of the socio-political environment in this period. On the other hand, a combination of these two arguments may provide a better explanation for the coalescence of Sahrawi identity.

The first hypothesis continues to be relevant to this chapter even though it begins in the sixteenth century because the more traditional approach has no limitations to how far back one can begin the study of nationality. Its flexibility may be one of its deficiencies because in the case of the Sahrawi there is no natural point of departure. Primordialist studies begin in the present,

\footnotetext{
114 This literally means 'Holy Cross of the Small Sea' in Spanish.
} 
move backward seeking a point of origin, and then work their way forward to the modern. The second hypothesis and its three derived explanations rely on a more diverse understanding of nationalities and allow for an identity to be approached from below-arguing for given attributes that can only be described as affinities or attachments to family or tribe, the land, and cultural links (custom, ancient myths). It also seeks explanations from above-either from geo-political dynamics and circumstances that have influenced the population or the manipulation direct or indirect from elites and 'ethnic entrepreneurs.' After the socio-historical description and commentary of the Sahrawi during this period, a critique follows of both hypotheses.

Several socio-political changes began to influence the dynamic of the Moroccan social landscape in the late fifteenth and early sixteenth centuries and of both the northern and southern stream of Sanhaja Berber. First, the northern stream became subdivided into smaller tribes that began to mix and thereby diffuse power in the southernmost parts of Morocco. These groups, including the Berber tribes from the Gudala, Lemta (Sanhaja), the Lamtuna (Sanhaja) and the Arab Hassani groups had already begun intermarrying. ${ }^{115}$ The number of nomads increased from both the Berber and Arab populations throughout the region and south into the Sahara because of the influx of goods and the Trans-Saharan trade routes. However, many of these nomads lived mostly by foraging for date palms, hunting desert game, raising livestock, and caravanning the salt (Norris 1986, 176). Second, "the northern section of the Sahara came increasingly under the domination of Arab nomads" who "imposed their 'protection' over the pre-Saharan oases and extracted tribute from the inhabitants and traders there" (Levtzion 2008b, 449). Norris comments

\footnotetext{
${ }^{115}$ Lydon comments that these ancient tribes, the Gazula (or Gazulah/Jazula), Lemta (also known as the Lamtah or Lemta), Lamtuna (or Lamtunah), Masufa, and Gudala, are considered of "Berber" origin. However, in terms of Sahrawi ancestry, only the Lemta, who were "a learned Sanhaja clan of the northwestern desert edge-a region geographers named the southern extremity of the Maghrib (Maghrib al-aqsa)," and Lamtuna are said to be from the Sanhaja-the true ancestors of modern-day Sahrawi. He also suggests that the Gazula are the "forefathers of the Tikna" (or Tekna) Confederation of tribes that still survive today in southern Morocco and northern Western Sahara. Ghislaine Lydon, On Trans-Saharan Trails: Islamic Law, Trade Networks, and Cross-Cultural Exchange in Nineteenth-Century Western Africa, (New York: Cambridge University Press, 2009) 60-61, 174. Norris also suggests that the Gazula are present today as "distant ancestors of those people whom we now call Tiknah." H. T. Norris, The Arab Conquest of the Arab Western Sahara (Harlow, UK: Longman and Libraire du Liban, 1986), 142, 246.
} 
that several of the subject Berber tribes in the Sous Valley became soldiers for the Banu Maqil, Awlad Hassan, and Banu Hassan (Norris 1986, 174).

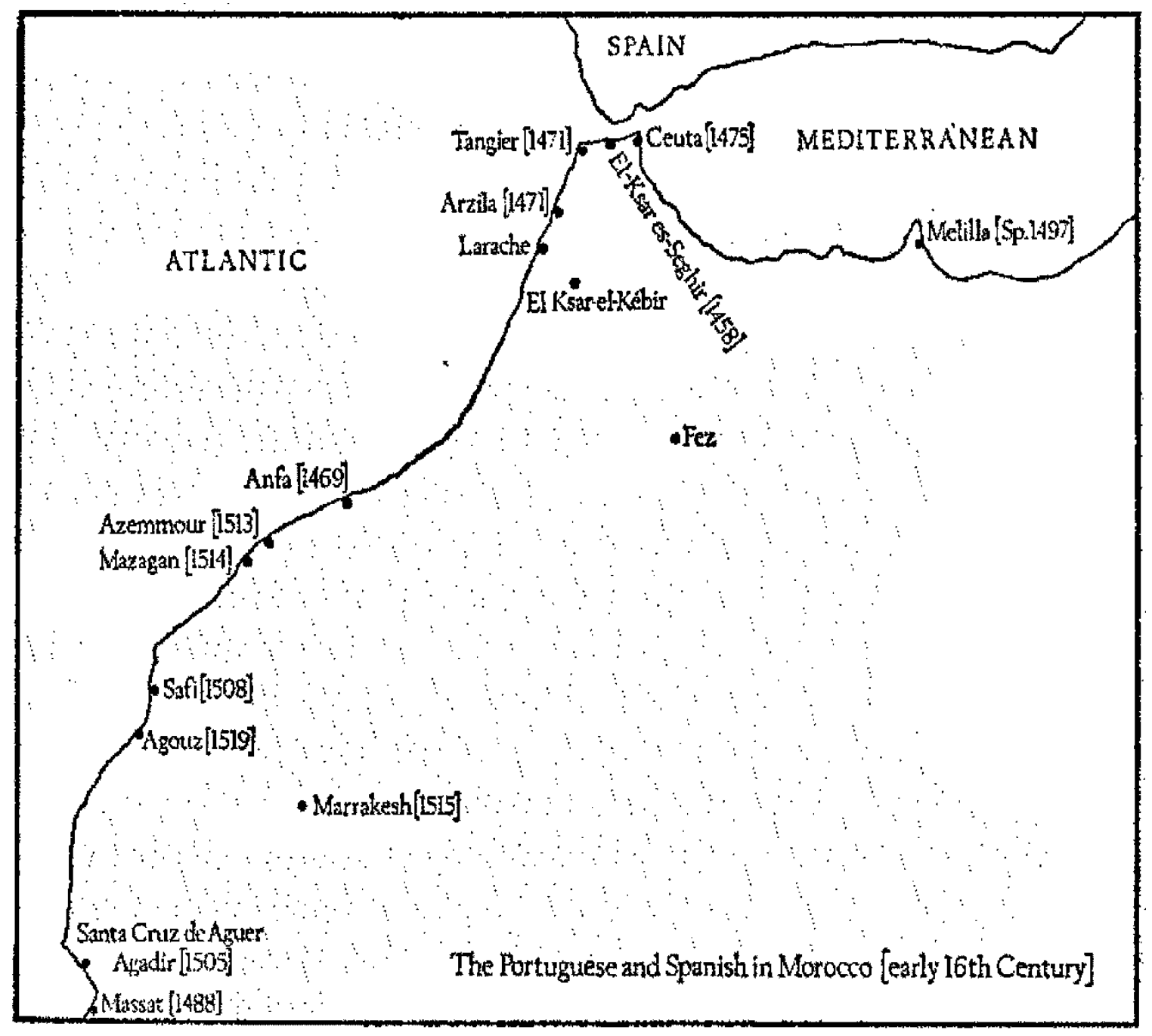

Map 4.1: Early Colonization of Morocco in Sixteenth Century ${ }^{116}$

Third, the "Portuguese raided nomad encampments of the 'Azenegues' (Sanahja) on the coast and took prisoners" (Levtzion 2008b, 451). The Banu Maqil formed auxiliary forces with the nomad Berbers, subdued the Fazula, which furnished "the model for later recruitment an

${ }^{116}$ Map taken from Charles-André Julien in History of North Africa-Tunisia, Algeria, Morocco: From the Arab Conquest to 1830, trans. John Petrie, (London: Routledge and Kegan Paul), 1970, 214. 
service, bondage even of the Zenagah ${ }^{117}$ to the Awlad Hassan in Mauritania” (Norris 1986, 174). Hodges remarks that in the sixteenth century, Leo Africanus ${ }^{118}$ and Luis de Mármol y Carvajal who both traveled "into the Western Sahara from Morocco in 1512 and 1556 respectively, reported the presence of both Sanhaja and an Arab tribe, the Oulad Delim" (Hodges 1983, 9). In Brown's edited notes on John Pory's translation of Leo Africanus' work, he comments that the "Zenega seem to have extended from the Atlantic to the Salt marshes of Trarza, from Western Sus and the Wad Draa on the north to Timbuktu in the south" (Brown 1896, 198). Gradually though, the Sanhaja name disappears through intermarriage with the Arab tribes, capture and enslavement by the Portuguese and rival tribesmen, and migration south toward the less populated Sahara. Fourth, the Wattasids (1472-1554) from their principal city of Fes (see map 4.2 below), instead of checking the incursions of the Portuguese and the Spanish, began to redirect their focus against another upstart rival - the southern sharifs ${ }^{119}$. Thereafter, Wattasid

\footnotetext{
${ }^{117}$ Zenagah (also spelled Zenaga or Znaga) before the invasion of the Arab Banu Hassan or Hassani tribes was a designation to that part of society associated with caretakers of livestock. Ahmed Mahmu'd wull Mudi, in "Genèse de la Hiérarchie Sociale et du Pouvoir Politique 'bidân'," by Mariella Villasante-De Beauvais, Cahiers d'Études Africaines, 37, Cahier 147 (1997): 594; It was also the name of a Sanhaja tribal confederation that later became a tributary tribe to the Arab Hassani after the war of Char Bubba. However, academic literature has used the term synonymously with Sanhaja. Encyclopedia Britannica, $11^{\text {th }}$ Edition, s.v. "Zenága," (1911), Google Play Books. Today, however, it is viewed as the corrupted (or derivative), Arabic form of Sanhaja. John Mercer, "The Cycle of Invasion and Unification in the Western Sahara," African Affairs, 75 No.301, (October 1976): 499; "Sanhaja," Anthony Pazzanita, Historical Dictionary of Western Sahara, (Lanham, MD: Scarecrow Press, 2006) 383-384.

\begin{abstract}
${ }^{118}$ Leo Africanus, whose original name in Arabic is al-Hasan ibn Muhammad al-Wazzan al-Fasi (but later christened as the Italian Giovanni Leone) was born c. 1485 in the Kingdom of Granada, Spain and died c. 1554 in Tunis, Tunisia. He was a traveler whose writings remained for some 400 years one of Europe's principal sources of information about Islam. "Around 1526, he completed his greatest work, Descrittione dell'Africa (1550; A Geographical Historie of Africa, 1600)." Encyclopedia Britannica, Online Edition, s.v. "Leo Africanus," accessed February 16, 2015, http://www.britannica.com/EBchecked/topic/336304/Leo-Africanus. See also Leo Africanus, The History and Description of Africa and of the Notable Things Therein Contained Vol. 1, trans. John Pory, edited by Dr. Robert Brown, (London: Bedford Press, 1896) 130-131, 146, 205.
\end{abstract}

119 Sharif is a term denoting a nobleman descended from Fatima and Ali and therefore of sharifian descent, direct descendants of the Prophet Muhammad. Despite the problems with these claims, much of the population supported the sharifs. Today it is a term applied to an Islamic ruler or clergy. 
Map 4.2: Morocco during the Wattasid Dynasty ${ }^{120}$

power deteriorated and "the governors of Safi ${ }^{121}$ " who "were making a great effort to gain possession of Marrakesh" allowed the emergence, "in the Sous, [of] the Beni S'ad or Sa'adians" (Julien 1970, 215). Subsequently, by the end of the fifteenth century, Marrakesh had ceased to recognize the Wattasid authority of Fes (Laroui 1977, 238).

As early as 1455, the southern Sanhaja had been in contact with, and reached the population across the Senegal River (see map 4.3 below). A letter dated from 1455 about the voyage of Luis de Cadamosto and Pedro de Sintra recounts that fifty miles beyond the Senegal River, de Cadamosto met the Damel (ruler) of Cayor ${ }^{122}$ for the purpose of trading horses and other items for the King's return payment of black slaves (Newitt 2010, 67-71). De Cadamosto writes that only a select few could visit and enter to see the King in his vast residence of enclosures. One such group included "the Christians who are allowed to go freely whenever they are met with and the Azenegi who are those who teach the law of Mohamet" (Ibid., 70). Newitt, who translated Caddeo's account of de Cadamosto's voyage to the Senegal, asserts in an endnote that these Azenegi were actually migrant Sanhaja traders, who inhabited the southwestern territory of the Sahara, observed Islam and practiced medicine (Ibid., 70-71). Additionally, when the Zenata-based dynasties of the Merinids and the Wattasids were ousted from their strongholds

\footnotetext{
${ }^{120}$ Taken from Dahiru Yahya, Morocco in the Sixteenth Century: Problems and Patterns in African Foreign Policy, (Atlantic Highlands: Humanities Press), 1981, xv.

${ }^{121}$ It was a ribat (a type of fortified monastery) "in the 13th century and was mentioned by the historian Ibn Khaldūn. The Portuguese occupied Safi (1508-41) and built a citadel, which now surrounds the 18th-century Keshla ([military enclave or] Casba). Safi prospered under the late 16th- and early 17th-century Sa 'dī sultans." Encyclopedia Britannica, Online Edition, s.v. "Safi," accessed February 11, 2015, http://www.britannica.com/EBchecked/topic/516146/Safi.

122 Cayor was an independent satellite controlled by the Wolof Empire "that dominated what is now inland Senegal during the early period of European contact with West Africa...In 1556 the nobles of Cayor threw off Wolof domination and established an independent state of their own on the Senegal coast. Encyclopedia Britannica, Online Edition, s.v. "Wolof Empire," accessed July 22, 2015, http://www.britannica.com/place/Wolof-empire\#ref221633.
} 
in Fes, many fled to the northern fringes of the Sahara. They, along with the Tadjakant (or Tajakant), are the modern descendants of Berber who now are found either in the "many sedentary centers of the northern half of the desert or "scattered all along the western edge of the desert, from southern Morocco southward through [what was once considered] the Spanish and western French Sahara" (Cabot Briggs 1960, 81). Apart from these subtle descriptions about the area and its history, little is known about the inhabitants prior to the middle of the seventeenth century. Only a little more has become known in the last two hundred years (Ibid., 211). The only remarkable note of the period is the increasing difficulty to choose and follow a specific tribe (or tribal confederation) that would lead to the present day Sahrawi. The general mixing of tribes among Arab and Berber along the Atlantic coast southwest into the Sous and Dra'a River Valleys 


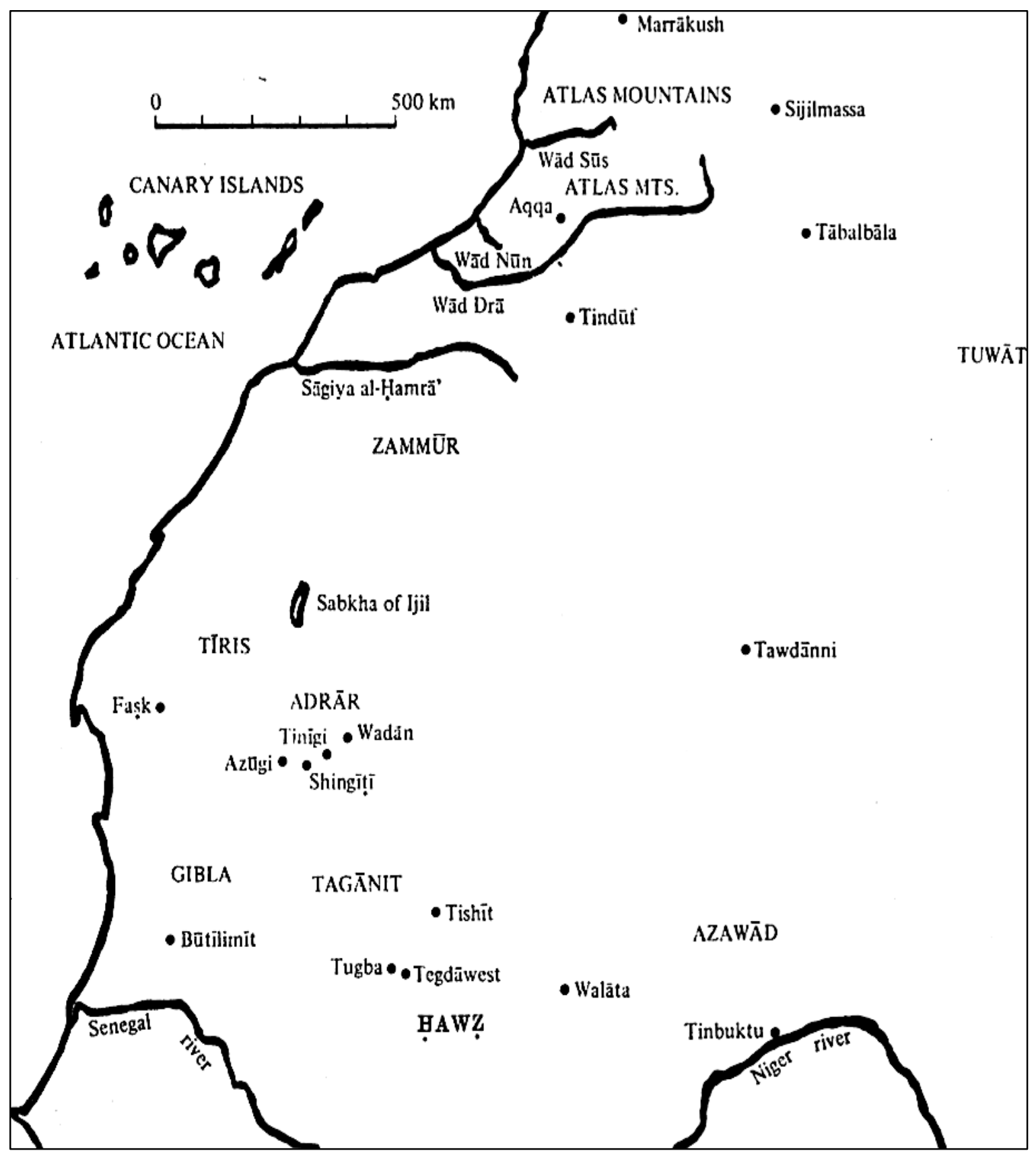

Map 4.3: The Greater Western Sahara ${ }^{123}$

(see map 4.3) only impedes in ascertaining a line of succession to the modern Sahrawi. The constant movement from one area to another because of conflict, pressure from the encroaching

${ }^{123}$ Map taken from Thomas Whitcomb, "New Evidence on the Origins of the Kunta," Bulletin of the School of Oriental and African Studies," Vol 38 (1), 1975, 104. 
Arab tribes, and nomadism further dampens specific evidence for Sahrawi origins. Moreover, many, if not most, of the Saharan tribes, both Berber and Arab, acted independently of each other. The only active association among tribes was as through alliances (in a confederation for protection or for raiding another tribe) and trade. However, these relationships did not produce any notion of Saharan identity. Identification was primarily tied to the tribe.

The Rise of the Sa'adians and Ouster of the Europeans (1494-1668)

In 1494 the Treaty of Tordesillas, between Spain and Portugal, traced a line of demarcation that divided the New World and other possessions in West Africa. Even though Portugal had won the possession of Melilla (in northern Morocco) according to the lines of demarcation provided at Tordesillas, John II of Portugal waived this right. Spanish incursions into the Maghreb began at the command of Archbishop Cisneros of Toledo (1499). However, the geo-political objective of establishing the Spanish Kingdom in the Mediterranean rather than in the Maghreb resulted in the "establishment of garrison posts (presidios) on strategic points on the coast, while leaving the interior to be held by indigenous rulers" (Abun-Nasr 1987, 147). The Portuguese reached the height of expansion during the Wattasid reign of Abu Abd Allah al-Shaykh Muhammad Ibn Yahya (or Muhammad al-Shaykh) (1472-1505) in what is now Morocco. A peace treaty between the Portuguese and al-Shaykh in 1489 led the Portuguese to 'abandon' the conquest of interior lands and concentrate on the southern periphery of 'Morocco.' The Sufi sharifs of the Sa'adians in the south "came forward to lead the Moroccan Muslims against the Portuguese" (Ibid., 208). The Sa'adians lived in the Valley of the Dra'a, came to prominence with the support of the leaders of the Sous, which led to the expulsion of the Portuguese from Santa Cruz de Mar Pequeña in 1524 and to the capture of Marrakesh in 1525.

The Sa'adians become the next potential ancestors to the Sahrawi in view of their move from the northern region of the Western Sahara into southern 'Morocco.' Also, their 
incorporation of these areas to their rule may provide, for the first time, the possible foundation for a Sahrawi nation. Beginning in 1524, the area south of the thirtieth parallel in latitude, the Sous and Dra'a River Valley and beyond into the Sequiet el-Hamra (see Map 4.3 above), was being overpowered by the rise of the Sa'adian sharifs supported by some of the surrounding tribes. These groups began to organize themselves politically for three distinct reasons. First, European, especially Portuguese, encroachment into the interior lands of southern and northern 'Morocco' alarmed some of the religious leaders of the region and despite the advantages of trade caused them to seek redress against these non-believers. Second, the centuries-old trade routes, which had been an important part of the Trans-Saharan economy were being challenged by European privateers and supported by their ruling monarchs at home. The Trans-Saharan caravan routes travelled between the mouth of the Senegal River valley, from Timbuktu and Gao, Mali across the Sahara to present-day Tindouf, Algeria. The Europeans attempted to monopolize trade by establishing trading posts not only on the Senegal River but also along the northwestern shores of modern Morocco. The substitution of the desert overland route for the faster sea voyages along the Atlantic coastline became a considerable European advantage. Consequently, one of the objectives for the sharif became the protection of this trade from European interference. Third, Sa'adi sharifian leaders also feared 'the Turkish peril.' The Ottomans had intervened to help the Banu Watta (Wattasids) remain in power and would not tolerate another group claiming religiopolitical leadership in the Maghrib. However, the Sa'adian leaders opposed the Ottomans because of Sa'adi claim to prophetic lineage. Thus, 'Christian' incursions, an already weak or passive Wattasid government, an Ottoman threat to southern Morocco, and a chaotic Western Sahara compelled some of the population and religious (Sufi) leaders to seek new leadership under the guise of holy war: The Sa'adians (Julien 1970, 222; Yahya 1981, 3). 


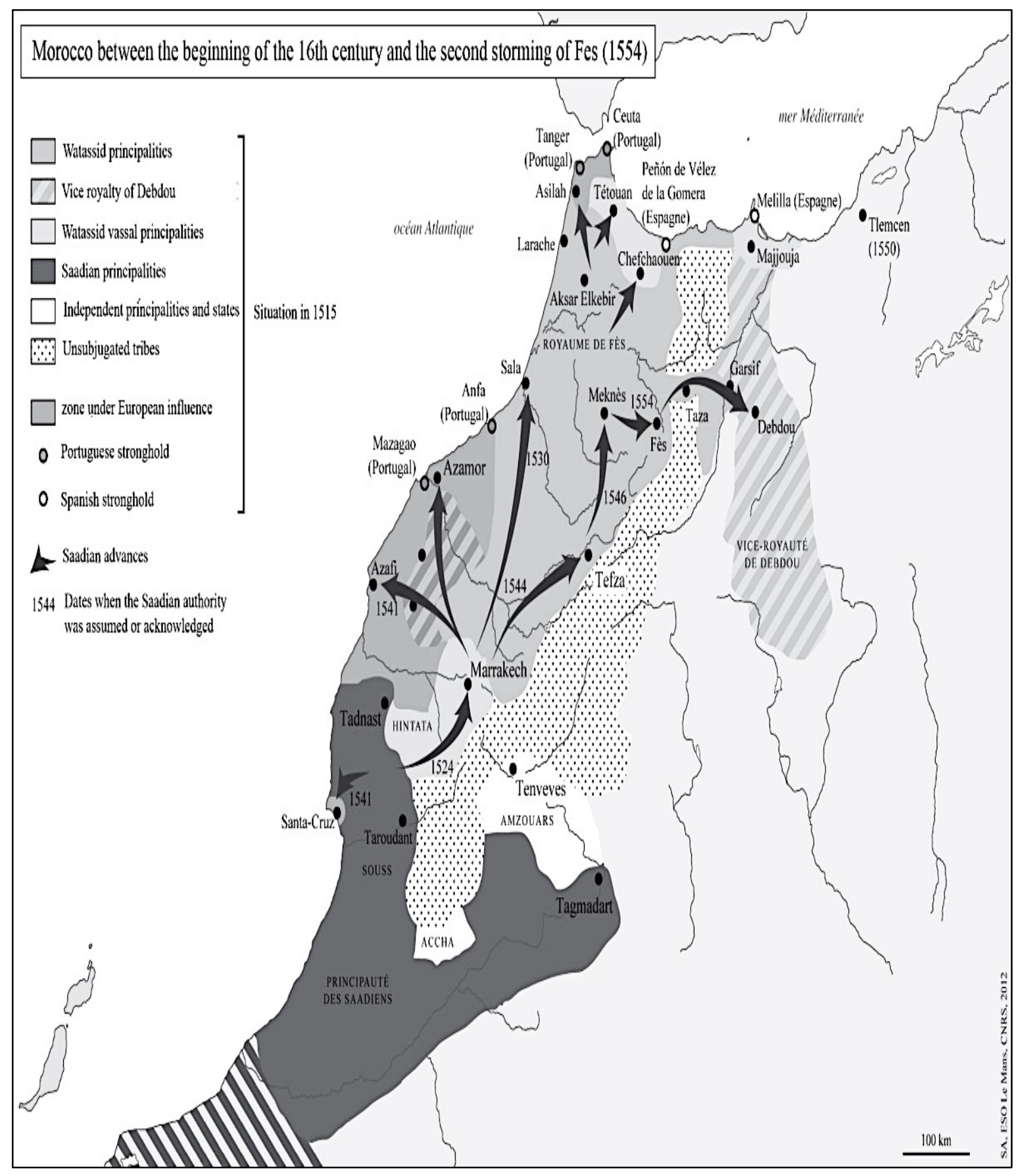

Map 4.4: The Wattasid and Sa'adian Quest for Control of Morocco ${ }^{124}$

\footnotetext{
${ }^{124}$ Map titled 'Morocco between the beginning of the $16^{\text {th }}$ century and the second storming of Fes (1554)' was taken from Mohamed El Mazouni, "Political and Religious Institutions under the Saadians," in Dominique Avon, ed., Politics Religion and State Building (1 $11^{\text {th }}-16 / 19^{\text {th }}$ Centuries), 2011-2012, http://hemed.univ-lemans.fr, accessed November 30, 2015, http:/hemed.univ-lemans.fr/cours2011/en/co/grain2 2 1.html .
} 
The Wattasids, the last Berber dynasty that controlled the nexus of 'Morocco' (Meknes, Fes and its northwest coast) whose populations still spoke Berber dialects perhaps with some mix of Arabic, do not figure prominently as ancestors to the Sahrawi. They did extend their power south of Marrakesh but these territories were vassal principalities and would later be lost to the Saadians (see map 4.4 below). Geographically, the Wattasids held Berber lands, especially in the Atlas Mountains but are far removed from consideration as forerunners to the Sahrawi. The Sa'adian, mostly of Arab origin and Arab-speaking were also composed of Berber tribes. They rose from what is now parts of the modern Western Sahara and attempted to consolidate power north and southeast. By virtue of geography, at this point in history, they are considered one of better contenders that may be linked to Sahrawi identity. However, several problems arose that mitigated Sa'adian consolidation of modern southern Morocco and contemporary Western Sahara.

The Saadians: The First Links to the Sahrawi?

The desert dwellers of the Western Sahara, who were not subject to the Banu Watta or the Sa'adi, the local tribes of the periphery and most of the southern regions of the southwest Sahara were under no sovereign entity. They ruled themselves and maintained their nomadic lifestyle. Yahya mentions, "the authority of the Marini-Wattasi sultans was acknowledged only in the capital of Fez and the immediate surrounding regions" (Yahya 1981, 2). Julien writes that:

It was a period when anarchy was gaining ground despite the efforts of the Wattasids to assert their authority. Southern Morocco was almost completely out of their control. The Hintata amirs, reigning at Marrakesh, were not capable of exacting obedience beyond the Atlas. The plain of the Sous, the anti-Atlas and the Dra' oases were de facto independent. But the people were concerned about Portuguese inroads, and their piety moved them to take up arms against the infidel $(1970,222)$.

Jacques-Meunié adds that: 
In the beginning of the $16^{\text {th }}$ century the whole of Saharan Morocco is outside the control of the dynasty that rules the north of the Atlas and has Fez as its capital. The major provinces in the South (...) are disintegrated into numerous independent districts of which some have only a village as capital (...) The temporal power is thus broken up into multiple authorities, [sic] which arebeing independent or enemies of one another-factors of insecurity and anarchy. $(1982,424-425)$

Leo Africanus, Yahya, and Abu-Nasr mention that the region surrounding the Sous was rife with tribal infighting led by Sufi orders. These Sufi leaders were angered at the Wattasid for not resisting Portuguese assaults.

The area was devoid of any overriding leadership that could counter the foreign intrusion. In fact, cohesive resistance may have been the result of the Portuguese themselves insisting on a representative from southern Morocco to negotiate terms to stop the fighting in the region. AbunNasr adds " $[\mathrm{t}]$ he ascent to power began when the leaders of Sus, divided amongst themselves and unable to agree upon one from their midst to represent them in their dealings with the Europeans, were prepared to accept a sharif as their head" (Abu-Nasr 1987, 209). It seems very probable that southern 'Morocco' was considered a contested geographical area rather than a cohesive, unitary state or kingdom. There were other tribal powers in the wider Western Sahara region. One group, noted by Criado, were the Reguibayt ${ }^{125}$ tribe (of Berber origin), whose creation and "subsequent development [would] make it one of the most important in the Sahara, is produced in the sixteenth century by Sidi Ahmed Erguibí ${ }^{126}$, at the approximate period of other tribes specifically Sahrawi, the Arosien [of Arab origin], descendants of Sid Ahmed Arosi, and the Ould Tidrarim by Sid Ahmed Bo Gambor [emphasis added]" 127 (Criado 1977, 76). Other tribes included the the

\footnotetext{
125 There a variety of spellings found throughout the literature: Rguibait, Reguibait, Reguibayt, or even Erguibat, however, here I will use Reguibayt because of its phonetic proximity to English.

${ }^{126}$ Caratini does not refute Sidi Ahmed Erguibi's existence but explains the difficulty of dating his actual birth and life as she attempts to corroborate whether he is a myth or an actual historical figure. Sophie Caratini, Les Rgaybat (16101934) Tome 1: Des Chameliers a la Conquête d'un Territoire (Paris: L’Harmattan, 1989), 42-43.

${ }^{127}$ Translated from the Spanish: "La fundación de la tribu Erguibat, cuyo "posterior desarrollo va a hacer de ella una de las más importantes del Sahara, se produce en el siglo XVI por Sidi Ahmed Erguibí, en la época aproximada que las
} 
Barabish (or Berabich, of Arab origin), Awlad Bu Sba (Arab and Berber mix), Kunta (of Arab origin with a Berber name), Tadjakant (Berber), and the Tekna (whose ethnic origins are debated between Arab and Berber). These groups spoke either a Berber (Znaga ${ }^{128}$ dialect) or that of Hassaniya (from the Banu Hassan). As Whitcomb summarized, it was "apparent from the accounts of the Portuguese explorations of the area during the ninth/fifteenth century, that the [Banu] Hassan were by that time numerous, widespread, and powerful, although the Znaga and Hassan were clearly still distinct peoples, each with its own language, customs, and dress" (Whitcomb 1975, 103).

Based on the sources above, the consolidation of power (even by the Sa'adians) would be challenging. The evidence also suggests that there was no overarching 'national' entity. For reasons stated above and because of the environmental dynamics of the region, some authors infer that Western Saharan society had already possessed a certain socio-political organization before the creation of the Kingdom of Morocco or Mauritania. (Africanus 1896, 145-149; Cabot Briggs 1960); Criado 1977, 76; Ensel 1999, 48; McDougall 2012, 84-85). These sources speak of an independent nuclei of inhabitants that, although they did not have a regional governor or ruler, was not controlled by a single principality or an absolute sultan. The evolution of power rested on a tribal hierarchy at the beginning of the $16^{\text {th }}$ century. Criado asserts that this hierarchy is still respected among the tribes of the SARIO (Saguia el-Hamra y Rio de Oro) today. $(1977,77)$ These tribal groups were a mix of Arab, Berber, even Black ethnicities. They communicated in different languages. Some tribes had actually become divided between sedentary and nomadic branches, such as the Tekna. Therefore, any notion of a proto-Sahrawi identity at this time is contestable. The only common feature that would serve as a foundation for a Sahrawi nation in

otras tribus específicamente Saharauis, los Arosien, descendientes de Sid Ahmed Arosi, y los Uld Tidrarim por Sid Ahmed Bo Gambor" in Ramón Criado, Pasión y Muerte de un Sueño Colonial, Versión Ruedo Ibérico, (ChatillonSous-Bagneux: SEG), 1977, 76.

${ }^{128}$ Sanhaja Berber 
this period would be the diverse set of tribal attributes - nomadic and sedentary; Berber, Black, and Arab; Hassaniya and Berber speaking. However, none of these groups 'imagined' themselves as such a huge conglomerate nation but as independent entities whose loyalty was first tied to clan and then tribe.

Abu Abdallah (or Muhammad) al-Qaim, representative of the Sa'adian House, was to pursue the ouster of the Portuguese. They continued to take advantage of trade with European merchants through the 1530s. In addition, the Sa'adian leadership was preoccupied with the geopolitical problems to their north with the Merinids and later with the Wattasids. In exchange for local goods, especially sugar, Europeans would barter away "war materials including arms, copper, iron, sulfur, and even saltpetre" (Abun-Nasr, 210). Ahmad al-'A'raj, who later became the leader of the Sa'adians, captured Marrakesh in $1525^{129}$ and agreed, after failed attempts by the Wattasid Dynasty based in Fes, to recognize him, to become ruler of Morocco-south of Tadla ${ }^{130}$ —in 1536. Jealous, his brother Muhammad al-Shaykh ${ }^{131}$, governor of Sous, moved to counteract al-Araj's power in 1540. By 1554, al-Shaykh had neutralized his brother, captured Agadir from the Portuguese, eliminated the Wattasids, taken Fes, and essentially had become the ruler of much of central Morocco.

\footnotetext{
${ }^{129}$ Although other accounts state that the Hintata of Marrakesh actually invited the Sous sharifs to establish their capital there. Thus, over the years of 1523-1524, Ahmad al-Araj, named as successor of the sharifians and who "was acknowledged from the Atlantic coast to Dra'a and from Agadir to Tensift," along with his brother Muhammad alShaykh as leader at Tarudant in the Sous, came to settle in Marrakesh. Yahya, Morocco in the Sixteenth Century, 7.

${ }^{130}$ Tadla is a flat central plain in the middle of Morocco situated northeast of Marrakesh, west of the Middle Atlas Mountains, and directly south of its present-day capital, Rabat.

131 This Muhammad al-Shaykh is not to be confused with the one that was previously mentioned. The first 'Muhammad al-Shaykh' was the founder of the Wattasid state of Fes in 1472 and ruled as Sultan until 1505. The 'Muhammad alShaykh' mentioned on this page was the acting governor of the Sous in the late $1520 \mathrm{~s}-1536$ and after neutralizing all his enemies became the Sa'adian sharif of Marrakesh (1544) and ruler of all Morocco (1554-1557). Abu-Nasr, 207.
} 
Prior to 1580 and the victory by al-Mansur, Laroui depicts North Africa as those lands divided among the Arabs, Berbers, and Moors ${ }^{132}$ but "confined to the middle Maghrib" (Laroui 1977, 242). For example, the great trading city hub of Sijilmasa ${ }^{133}(757 \approx 1390$ s AD) was no longer functioning and the cities on the coast had already been taken by the Portuguese or Spanish monarchy. In 1578, after the 'Battle of the Three Kings' on the field of al-Kasr alKabir, ${ }^{134}$ Ahmad al-Mansur succeeded his brother Abd al-Malik (who defeated the Portuguese King Sebastian and Muhammad al-Mutawakkil, a usurper to his reign and collaborator of the Ottoman Turks) to the Sa'adian throne. Upon the death of King Sebastian, Spain was allowed to annex the Portuguese presidios because Portugal had no heir. By 1580, Spain had appropriated Portugal; unlike the Portuguese, the Spanish would administer the colonies by preserving the status quo (Abun-Nasr, 215). In 1591, the forces of the Moroccan Sultan, Ahmad al-Mansur, moved southward to take the salt mines of Taghaza (see Map 4.3). Because of his ambition to unite the Muslims of West Africa and rival the power of the Ottomans, he chose to invade the Songhay Empire in Timbuktu. Despite guerilla revolts by the Songhay, the Sultan's forces were able to assert partial control of the Empire by 1594.

Prior to al-Mansur (1578), the Sa'adians were hard-pressed to dominate the southern regions of the Western Sahara. The heart of Morocco, now located in Marrakesh and Fes was intermittently difficult to manage. The restive Arab and Berber tribes south and southeast were also very restive. The abundance of these groups, the formation of smaller principalities, and

\footnotetext{
132 The Moors were "members of the Muslim population of Spain, of mixed Arab, Spanish, and Berber origins, who created Arab Andalusian civilization and subsequently settled as refugees in North Africa between the $11^{\text {th }}$ and $17^{\text {th }}$ centuries." Encyclopedia Britannica, 8, 15th ed., s.v., "Moor," (Chicago: Encyclopedia Britannica, Inc., 2010$), 301$.

133 Sijilmasa is located (its ruins) "at the beginning of the Maghrib in the Tafilalt oasis at the northern edge of the Sahara Desert." James A. Miller, "Trading Through Islam: The Interconnection of Sijilmasa, Ghana and the Almoravid Movement," in ed., Julia-Clancy Smith, North Africa, Islam and the Mediterranean World: From the Almoravids to the Algerian War (Portland: Frank Cass Publishers, 2001), 29.

${ }^{134}$ It is known as Alcazar in Spanish. All three kings were either killed or died during the battle although his own guard poisoned Al-Malik.
} 
European coastal encroachments make it difficult to state with certainty which group - Sa'adians, a vassal tribe of the Sa'adians, or one of peripheral tribes-is directly tied to the modern Sahrawi of today. There is no viable proto-Sahrawi groups at this stage. These are the more prominent difficulties, while others in the following point to the cosmopolitan nature of identity during and after al-Mansur's reign.

\section{Group Identity during the Sa'adian Dynasty}

One of the problems that has not been addressed is the close historical relationship that the successive leadership and identity groups that occupied the territory currently identified as the Western Sahara and the Kingdom of Morocco have shared. Some historians begin Moroccan history with the Berber dynasties mentioned in the previous chapter and indelibly complicate the matter of historical delineation. There is no satisfactory manner to identify at what point these shared histories diverge, especially in the region from the Sous River Valley southwest through the River Dra'a southwest to the Sequiet el-Hamra (see map 4.5 below). The term 'Morocco' has been used in historical accounts and on old maps as a designation for the modern city of Marrakesh. The designation of a 'kingdom' of Morocco began in the early eighteenth century. Earlier historical accounts describe how sultans, not kings, led 'Morocco.' Morocco seems to describe a geographic area in North Africa rather than a sovereign, independent political entity. In fact, the fourteenth to the sixteenth centuries, the region of Morocco was divided among the sultanate based in Fes and led by the Wattasids; the Sharifian Sultan based in Marrakesh; and the more southerly tribal confederations in the Kingdom of Sous.

This problem is directly tied to the origins of Moroccan population groups as well as the establishment of Morocco itself. For instance, al-Mansur's army that crossed the Sahara (1591) south to defeat the Songhay Empire consisted of Andalusian mercenaries, renegades ("captured Europeans who had converted to Islam"), "negroes, Kabyles and Ottoman deserters," even eight 
Christian bodyguards for the leader, Pasha Judar of Granada, of the invasion force, who himself was not 'Moroccan.' (Julien 1970, 233; Michel 1995). Despite Julien's Kabyle categorization, these Kabyle were ethnic Berber. Roughly half of Judar's force was not from Morocco proper. Additionally, Sa'adian controlled territory was a mix of Arab and Berber and so there must have been non-Moorish or Maghrebi Arabs but they may have been the minority contingent of the invasion force. Generally, there were distinctions made among Maghrebi Arab, Maghrebi Berber, Moorish Arab and Berber, and Black based on language, skin color, and region of origin. However, the population groups of the Maghreb held to their family of tribes. Not only was there no "Sahrawi" identity group during these centuries, but also not even a "Moroccan" identity group. Rather, there were only ruling dynasties over "population groups" whose identity appears to be very fluid.

A contemporary issue in areas of southern Morocco, ${ }^{135}$ but one which began much earlier in history, is that of racial identity. Today, Moroccans are generally regarded to be of either Berber or Arab descent. However, Morocco typically describes its original inhabitants as those who were not only of Arab (from the Arabian Peninsula), but also of sharifian (see footnote seven) descent. 'Shurfas' (or Sharifians) claim “in the eighth century, Sharif Idriss bin Abdallah...migrated from the Arabian Peninsula to Morocco and founded the first national dynasty" (Ensel 1999, 21). Ensel states that this is the myth of the origin of the Moroccan nation. Today, Morocco is still led by a Sharifian dynastic monarch, "albeit from a different genealogical branch (Alawi) than the Idriss" (Ensel 1999, 21). Monarchical discourse, for the most part, does not allude to Berbers as the original inhabitants. In fact, Pazzanita $(2006,385)$ writes that, over the period of 1550-1640, the encroaching Arab tribes, especially the Banu Hassan,

\footnotetext{
135 The geographical designation of 'southern Morocco' is describing the area from the Sous region southwest to the Sequiet el-Hamra in Western Sahara, but does not include the whole of Western Sahara proper.
} 


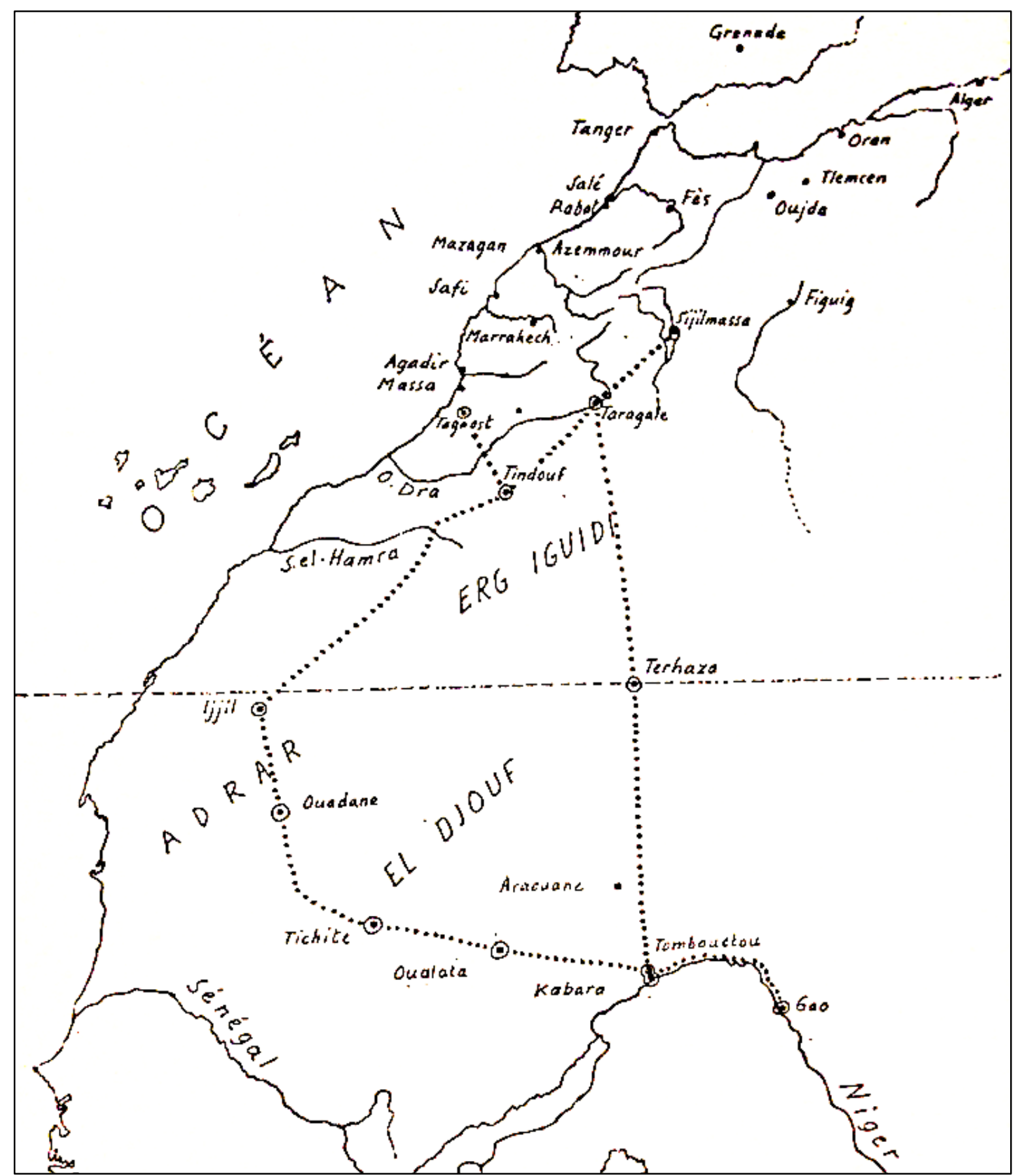

Map 4.5: Greater Western Sahara in the Sixteenth Century ${ }^{136}$

${ }^{136}$ Map taken, adapted, and titles 'du Maroc au Sudan,' from D. Jacques-Meunié, Le Maroc Saharien, des Origines à 1670, 2 Volumes (Paris: Les Belles Lettres, 1982), 573. 
"gradually vanquished and vassalized increasing numbers of Sanhaja," who were direct descendants of the Berbers. Thus, in identity-contested regions of Morocco, such as the Dra'a River Valley (labeled 'O. Dra' in map 4.5), where the Arab (Ahrar) ${ }^{137}$, Berber, and black African cohabitate, a kind of semi-caste or class has developed. These socio-ethnic categories are usually organized with the Sharifian Arab above the Berber, Haratin ${ }^{138}$ (free Black), and finally the 'Abid (descendants of slaves). ${ }^{139}$

Upon the death of Ahmad al-Mansur (1578-1603), the Sa'adian Dynasty was already losing its hold on power. By the end of the fifteenth and early sixteenth centuries, Ottoman encroachment and the internecine conflict among the kingdoms and tribes in North Africa had weakened Sa'adian power in the region. Al-Mansur had claimed sovereignty over the whole width of the northern belt of the Sudan, from Wolof to Bornu, from the lower Senegal river to Lake Chad but from conquest and "nominal allegiance" (Levtzion 2008b, 415). His power resided in a compromise with the marabouts ${ }^{140}$ or sharifs and alliances with the English against the Spanish. His army was also composed of various tribes, Turks, Moors, and foreigners (at times even Christian exiles). The Trans-Saharan trade with 'Sudan' was also overtaken by competition from Brazilian sugar. Gold from the Sudan dried up. Europeans no longer needed

\footnotetext{
${ }^{137}$ Freemen

138 "Scholars speculate that the Haratin came into being as a result of ancient interbreeding between indigenous blacks and Indo-Europeans, possibly Berbers." Encyclopedia Britannica, 5, 15 th s.v., "Haratin," 694. In other literature, the Haratin are described as 'former slaves,' or 'Black Moors.' "Mauritania-Haratin," Minority Rights Group International, April 2013, accessed August 03, 2016, http://minorityrights.org/minorities/haratin/ . Toyin Falol, The African Diaspora: Slavery, Modernity, and Globalization (Rochester, NY: University of Rochester Press, 2013), 42. However, today the 'Haratines,' especially in countries such as modern Mauritania, are considered former slaves. Despite passed legislation in Mauretania, criminalization of slavery is still tolerated by society.
}

\footnotetext{
${ }^{139}$ Remco Ensel's anthropological/ethnological fieldwork among the population of the Ktawa Oasis in the Dra'a River Region indicated that at the time there were clear distinctions among Arab of Sharifian descent or Ahrar, Black African who were never slaves, categorized as Haratin black, and Black 'Abid (actual descendants of slaves). Saints and Servants in Southern Morocco, 1999, ix-x and 2-3.

140 "Marabout is the name given, especially in North Africa, to a Muslim saint or to his descendants." The term is "derived from the Arabic murabit through the Portuguese marabuto (Spa. Morabito)." H.A.R. Gibb and J. H. Kramers, Shorter Encyclopedia of Islam, s.v., "marabout," (Ithaca, NY: Cornell University Press, 1965), 325. See chap. 3, footnote no. 65.
} 
alliances with Morocco. Al-Mansur's sons divided his Empire again and led their smaller positions from Marrakesh and Fes. Local powers, including the religious chiefs-sharifs, maintained their territories. Levtzion adds that "continuous warfare" after Al-Mansur's death "introduced a period of anarchy, one of the darkest in Moroccan history" which led to "insecurity on the Saharan routes," and thereby diminished "the flow of gold from the Sudan" $(1975,148)$. Laroui recounts this fragmentation of history: "West of the Maghrib, ...under the Sharifs, the state was strong only when it was independent of society and maintained its power only by recognizing the legitimacy of the local powers... it was a mere shadow of a state, because it was not rooted in the soil of the Maghrib" (Laroui 1977, 259).

This appeal to soil evokes the primordial approach to national identity. However, Saharan society was characterized by a balance of power among the local chieftains, a more palatable view for constructivism. Despite creating a cohesive state enterprise, there is still a surprisingly interesting debate about Al-Mansur's political entity. Identity groups can exist without a having to form, or existing in, a state structure. This example only demonstrates how contentious national identity can become. Conventional Moroccan history formally begins with the Sa'adian Empire, but an argument for the existence of a state based on the notion of the "pure Moroccan" is untenable in view of the socio-political environment. At this time in the region, it is undeniable that Morocco had little control before and after Al-Mansur's reign over the area now called the 'Western Sahara' or its environs. This fact also questions the type of cohesiveness that al-Mansur created during his reign and why it disintegrated so quickly.

Al-Mansur did rule over a considerable part of Morocco for a quarter century. However, his sovereignty extended in name only outside the confines of central Morocco and at times for a very short period (i.e., three years governing the former Songhay Empire). His reign, as well as for the whole of the Sa'adian Dynasty, was characterized by several identity groups mentioned above. There were also distinct categories of races, even mixes of races among the population in 
'Morocco' and across the southwestern and southern regions of the Sahara. This suggests that if Morocco in the sixteenth century was not based on a coherent 'Moroccan' identity, it is difficult to expect to find a 'Sahrawi' or proto-Sahrawi group in the area to the southwest of Morocco proper. Any form of cohesion established was monarchical but weakened by a heterogeneous population that was exemplified in the composition of the Sa'adian armies. The population remained tribal and segmented, undermining the sense of a national identity - in this case, a proto-Sahrawi identity.

\section{Sanhaja Identity after the War of Shar Bouba}

The history of the greater Western Sahara, especially in modern-day Mauritania, from the $1500 \mathrm{~s}$ to the late 1600s has been far less documented than that of Morocco. This region of the world lacks prominent empire-builders, dynamic religious leaders, or a record of key historical events. Documentation has to be uncovered reading Mauritanian history. However, chronological history of Mauritania for this period is insufficient because many of the volumes that describe it leave huge historical gaps. The period from 1524 to 1758 is one of them. There is one major historical event that sheds light on the resulting Arab dominance leading up to 1668. It also highlights the last historical moment of the southern Sanhaja tribes who could possibly be the ancestral link to the Sahrawi. This was the Mauritanian Thirty-Year War, also called the Shar Bouba War(s), ${ }^{141}$ which took place between 1644 and 1674. This section asks whether the southern Sanhaja of this period are the rightful ancestors of contemporary Sahrawis.

By 1664, the southern Sanhaja had already been weakened and had relegated their status as warriors becoming "devoted to Islamic learning and piety, being known as Zawáyá or maraboutic tribes" (Levtzion 2008a, 199). By the fifteenth century, the Arab Hassani warrior

\footnotetext{
${ }^{141}$ Different spellings have been found among the various sources, including Shurbubba, Shar Buba, Char Bobha, or Char Bouba. However, it is also referred to as the Mauritanian Thirty Year's War. Mulero Clemente 1945, Gray 1975, Norris 1986, and Pazzanita 2008. Here, I will compromise and will label it as the Shar Bouba War.
} 
tribes had penetrated the southwestern Sahara and subjugated the Sanhaja. This pressure against the Zawáyá resulted in an ongoing battle that pitted the last bastion of Sanhaja Berbers against the Hassani Arabs. The Hassani rulers had extracted tribute or horma ${ }^{142}$ from the more maraboutic tribes in exchange for protection. However, protection was inadequate and led to insecurity, especially along the trade routes. One crusading spirit from among the Lamtuna Berber, later named Nasr al-Din al-Daymani (Tashumsha ${ }^{143}$ Confederation) began to proselytize and advocate for a more devout following of Islam (Webb Jr. 1995b, 458; Hall 2007, 134). Nasr al-Din “appointed a vizier and four qadis ${ }^{144}$, and was determined to establish order and political stability in the Qibla (the southern Sahara). Fighting against warriors who 'cut roads', neglected Islam and oppressed the believers; creating a supra-tribal community to overcome fragmentation; establishing a new divinely guided order: these were the goals" of al-Din (Levtzion 2008a, 200).

Many of the remaining Sanhaja, who were most numerous in the deep southwest of Western Sahara proper and, present-day southern Mauritania, had extended themselves farther south to the northern fringes of the Senegal River region and protested against Hassani absorption. Many of these Zawaya immediately heeded the call of Nasr al-Din (whose original name was Awbek bin Ashfaga) for several reasons. They faced discrimination from the Hassani tribes by way of the unjust tribute imposed on them. As a tributary tribe, they were relegated to secondary status in the contemporary tribal hierarchies. This was difficult for the Zawaya to accept since the Banu Hassan were not invited and thus were seen as 'invaders.' Nasr al-Din might have also had economic reasons for his pursuit of power. At the mouth of the Senegal River, the French had already established a trading post. Soon much of the trade that was

\footnotetext{
${ }^{142}$ Horma, hurmah, or ghorma was "a payment to Hassani protectors, on demand, of annual sheep, or two calves, or a piece of guinée cloth.” Norris, The Arab Conquest of the Arab Western Sahara, 37.

${ }^{143}$ A confederation of five tribes that spoke the Berber Zenaga dialect.

${ }^{144}$ A Qadi or Qadhi is a judge. "A per son of good reputation who is versed in Islamic jurisprudence and acts as a judge in civil and criminal matters. Adamec, Historical Dictionary of Islam, s.v., "Judge," 152.
} 
flourishing along the Senegal River and north along the trans-Saharan trade route was monopolized by European traders. This economic consideration was "associated with the growth of French trade on the Senegal since the first half of the seventeenth century. By controlling the entrepôts for the gum trade on the Senegal he could offset the control of the Hassan over the trade to the ports of the Saharan coast" (Levtzion 2008a, 200). If trade in the north was disrupted and security was lacking due to the fragmentary nature of the northwestern Atlantic Sahara, Nasr alDin's goal was to gain control and impose social order. Additionally, Nasr a-Din not only "wanted the Black riverine and savanna peoples to embrace a stricter, more rigorous adherence to Islamic principles" but also sought a more pious order among the Hassani population who were not considered faithful to Islam (Webb Jr. 1995a, 32).

Norris, in his impressive The Arab Conquest of the Western Sahara, writes that many of the stories, especially those of the War of Shar Bouba War were derived from hagiographical sources. He describes some of the accounts by ancient Arabic historiographers of the Western Sahara as common folk tales because there are no external historical sources to confirm or deny them. These accounts are frequently written in commemoration of saintly figures. In his book Norris relates that even before the age of Al-Mansur and the Alawite Dynasty, the Banu Hassan (as a giant sub-tribe of the Maqil Arabs) had begun their conquest of the Western Sahara as they marched west toward the coast. Commenting on the 1506 work of Valentin Fernandes ${ }^{145}$, Norris states that the "Mountain of Kedyet Ijjel, near Tiris and close to a salt mine that [sic] was later controlled by the Kuntah ${ }^{146}$, was a bastion of the Saharan Lamtunah ${ }^{147}$. 'The kings of this

\footnotetext{
${ }^{145}$ Valentin Fernandes, a German printer who worked in Lisbon from 1495 to 1513 compiled several works on Africa and published them in 1506.

146 "The Kunta were probably formed in the ninth/fifteenth or tenth/sixteenth century, in the north-western Sahara between the Adrar and the Sagiya al-Hamra... the Kunta divided into two branches, one of which remained in the west, eventually moving to the central western Sahara and the south-western Sahara, while the other moved to the east towards the central Sahara, and then south to the Azawad, north of the Niger bend, early in the twelfth/eighteenth century." Whitcomb, "New Evidence on the Origins of the Kunta," 1975,105.
} 
mountain, as all the population, are Aznages. They are the great enemies of the Arabs" (Norris 1986, 35). Norris suggests that these 'Arabs' effectively subjugated the Lamtuna, who had "little choice but to go south or to make peace with the Hassanis" and were the Awlad Hassan (Ibid., $35)$.

Nasr al-Din began his jihad in the southern fringes of modern-day Mauritania in 1664 . His forces were able to gain the upper hand at first and defeat the black forces of the Senegal. From the Senegal, al-Din moved northeast against the Hassani tribe. He met the Hassani warriors in three battles for control of key commercial centers. However, Babba, ${ }^{148}$ one of the tributaries, called upon the aid of Hadi, ${ }^{149}$ chief of the Trarza, one of the Hassani tribes, to counter the al-Din threat. Tradition would characterize these engagements as the Shar Bouba War. Mulero Clemente writes that the Hassani invaders had "finally triumphed" over the Zawaya Berbers because the former "were supported by the Sultans of the Maghreb and ended up founding the Takuler" Empire"151 $(1945,79)$. This account has been described in one of Shaykh Baba's poems but Norris speculates that the 30-year war probably refers to al-Din's lifetime and the "the imposition of the Hassani" over "other groups in the south-west of Mauritania" (Norris 1986, 36). The battle of 1674 at Tin Yedfad proved disastrous for the Lamtuna and Tashumsha Berbers.

These southern Sanhaja Berbers were decisively defeated in this third battle at the hands of a more experienced group of nomadic Arab warriors. The remnants of the Sanhaja were no

\footnotetext{
${ }^{147}$ Written here as Lamtuna are a Sanhaja sub-tribe. See Chapter 3, page 4, footnote 61.

${ }^{148}$ The name of the tributary tribe of the Tashidbit Lamtuna

${ }^{149}$ Shaykh al-Qadi Muhammad ibn Mahmud Babba (or Baba) had asked for the help of the Hassani Banu Maghfar Prince of Trarza (or Trarzah), Hadi Ibn Ahmad Ibn Daman. Norris, The Arab Conquest of the Arab Western Sahara, 35

${ }^{150}$ The Takuler (Sp.) Empire refers to the founding of the Tukulor (Fr. Toucouleur) Muslim theocracy in 1854 in the Senegambia.

${ }^{151}$ Taken from the Spanish and translated by the author, "al fin triunfaron los invasores [Hassan] que estaban apoyados por los Sultanes del Mogreb y que acabaron fundando el imperio Takuler in Manuel Mulero Clemente, Los Territorios Españoles del Sahara y Sus Grupos Nómadas (Las Palmas de Gran Canaria, Spain: 'El Siglo' de Sánchez Talavera, 1945), 79.
} 
longer allowed to raise arms. They were forced to pay tribute again for protection, "renounced all pretensions to...military and political" authority; remained as ulama, which deepened their spiritual militancy; and were obliged to give the milk from their herds and water from the wells to the warrior Hassani (Levtzion 2008a, 201). The Berbers became Zenaga (a derivative of Sanhaja), tributaries of the Arabs by peace treaty (Pazzanita 2006, 385). Even before end of the sixteenth century, the Awlad Hassan had already permeated much of Berber society in the southwestern Sahara. Lamtuna remnants had been nominally subject to the Peul ${ }^{152}$ of the Trarza until 1638 and were largely repressed by several Hassani tribes_-leading to military resistance. "Several of the Zwaya leaders had married into Hassani families, and even when the conflict was at its most bitter...certain tribes remained aloof from the war" (Norris 1986, 37-38). At the same time, the Sultans of Morocco became active in support of the Mauritanian Emirates. Appeals to the Sultan by the Hassani and the aid that was given to the Arab armies helped forge an alliance in 1678 between Moulay Hassan who "received the submission of many of the tribes of Awlad Hassan in the entire Western Sahara" (Ibid., 39).

The identity of the southern Sanhaja tribes was transformed from 'warrior' to clerical and lost an essential link to the modern Sahrawi. Much of their population was absorbed by the Arab. The decline of the Sanhaja Berber in the deep southwestern Sahara coincided with the rise of the Alawite Dynasty in southern Morocco. Subsequently, the Banu Hassan merged with the Sanhaja to form a tribe led by Sidi Ahmad Erguibi. The tribe of the Reguibayt ${ }^{153}$ is sometimes called

\footnotetext{
152 The Peul also known as Fulani, "a people of obscure origins, expanded eastward from" Trarza and "Futa Toro in Lower Senegal in the $14^{\text {th }}$ century" into the Niger River Bend. They established an Empire that is now known as the Sokoto Calipahte in 1804, today relegated to a province of Northern Nigeria. The Fulani, however, are found scattered throughout West Africa. Encyclopedia Britannica, s.v., "Fulani Empire," "Fulani," 5, 15 ${ }^{\text {th }}$ ed., 2015, 42; New World Encyclopedia, s.v., "Fulani Sultanate," 21 November 2013, accessed August 04, 2016, http://www.newworldencyclopedia.org/entry/Fulani Sultanate.

153 Presently "the most numerous and influential tribe of the Western Sahara," having "many fractions and subfractions and which is thought to be of predominantly Sanhaja Berber extraction" are found throughout northwest Africa. Pazzanita describes the Reguibayt as the "largest component of the Sahrawi nationalist movement" assisting the POLISARIO in the 1970 s and well into the early $21^{\text {st }}$ century "by virtue of the sheer numbers as well as their traditionally independent attitude and warlike history." Historical Dictionary of the Western Sahara, 363-367.
} 
Tekna in the Sequiet el-Hamra region. This merger also created and adapted the Arabic Hassaniya dialect of the present-day Sahrawi people, supplanting the Sanhaja Berber dialect. The Sanhaja Berber become linguistically disconnected from modern Sahrawi speakers and displaced geographically from the Western Sahara. The only remnants of the southern Sanhaja (Zenaga) survive in southwestern Mauritania and the Senegal ${ }^{154}$. Their connections to the Sahrawi today remain unconvincing. Thereafter, the Hassani tribes become dominant south of Morocco. Despite being poor "and thus mobile and with nothing to lose," these Hassaniya tribes ruled the desert, possessed a "superior vitality" through desert warfare, adapting to the desert way of life (Mercer 1976, 500). Still, although these Hassaniya Arabo-Berbers (Tekna) of the Sahara were mostly free along the littoral desert, these primary descendants of the Western Sahara remained divided among tribal affiliations. The divisions make it difficult to link them directly to the Sahrawi unless the claims include all tribes of the Western Sahara who at one point or another settled and traversed the region. However, such claims prove even more daunting.

The Alawite Sultanate 1669 - 1757: Contentious Concepts of Identity and Territoriality Despite intermittent cohesiveness along the northwestern Atlantic coast of Morocco, many of the ruling factions were rivals. Until al-Mansur's reign, all were incapable of fending off European incursions, Moorish ${ }^{155}$ exiles from Iberia and the gradual intervention of the Ottoman Turks. In addition, the research indicates that the socio-political history in this area of the world

\footnotetext{
${ }^{154}$ Today, Sanhaja of the northern stream still exist in small pockets of the Rif in northern Morocco and in parts of the Middle Atlas Mountains in eastern Morocco.

${ }^{155}$ Moor is the term derived from Latin that denotes the mostly Muslim population that lived on the Iberian Peninsula before the Spanish Reconquista and then fled across the Mediterranean to present-day Mauritania, the Western Sahara, and Morocco. According to C.C. Stewart, "the appellation... has been applied at various times to Muslim peoples from Andalusia to the Senegal basin" where they eventually mixed with Berber, Black, and Arab tribes. "Political Authority and Social Stratification in Mauritania," in Ernest Gellner and Charles Micaud, eds., Arabs and Berbers: From Tribe to Nation in North Africa (London: Duckworth and Co.) 1973, 377.
} 


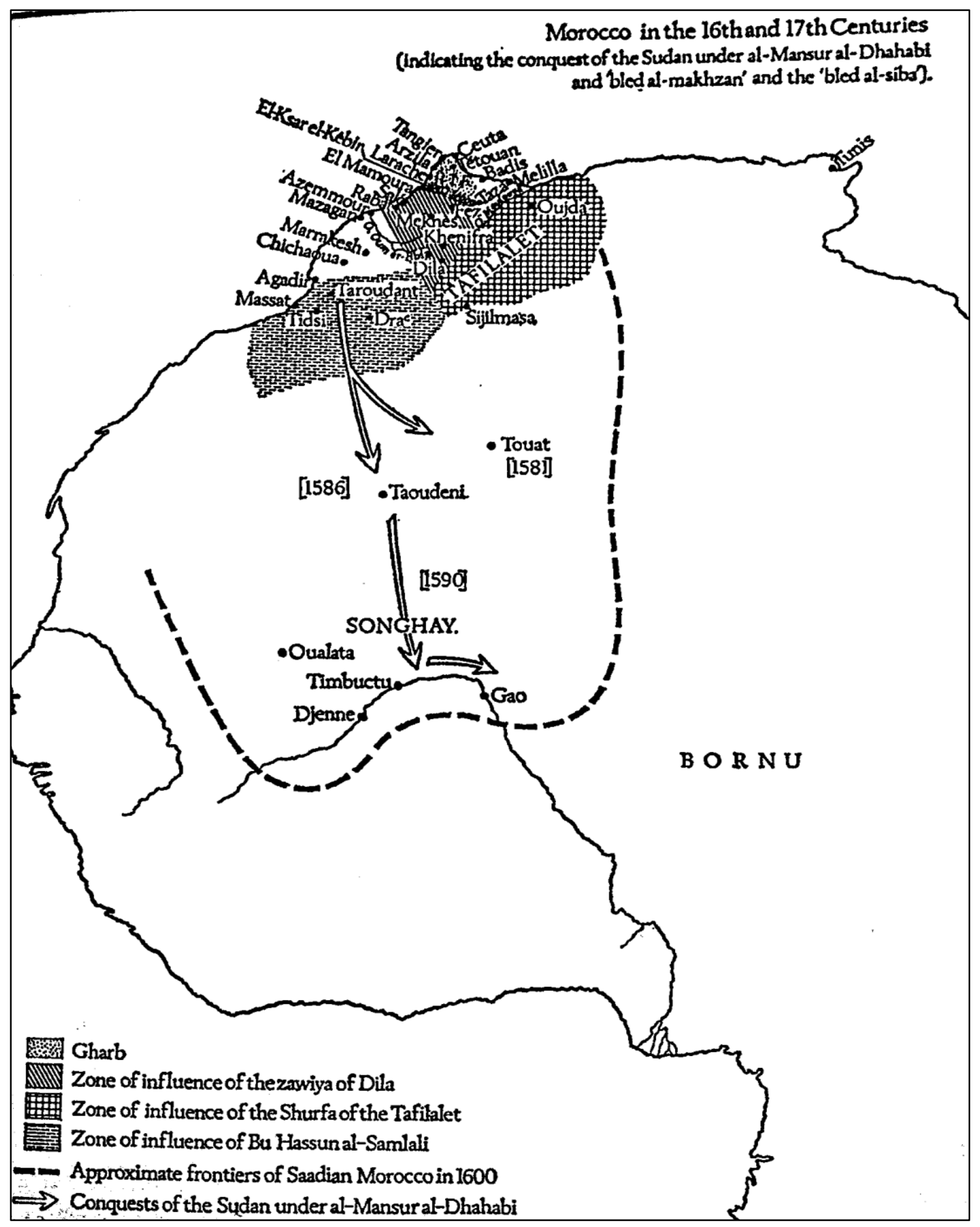

Figure 4.6: Morocco in the Sixteenth and Seventeenth Centuries ${ }^{156}$

${ }^{156}$ Charles-André Julien, History of North Africa-Tunisia, Algeria, Morocco: From the Arab Conquest to 1830, Translated by John Petrie, (London: Routledge and Kegan Paul), 1970, 231. 
has been concerned with the nature of trade, alliances, and the power of the Sultans and monarchs of the Iberian Peninsula. Discoveries made at this time were also prominent in the journals of these adventurers ${ }^{157}$ but there is little account of the population in the northwest and western coasts of North Africa that led into the western Sahara. Much of the region's history remains in parchments (i.e., Timbuktu), stored in personal libraries, which have not been thoroughly investigated. Several stories that have been related here have been documented by sources tied to oral tradition. The lack of textual history notwithstanding, tradition and documented history have shown that there is ample evidence to suggest that there was never a controlled group nor one authoritative dynasty or empire that had control of this area for much more than fifty years. Additionally, although many of the Arab tribes asked for aid and some submitted to the authority of the Moroccan Sultanate, these were nominal at best. Evidence suggests that the Saharan tribes probably recognized the Sultan's spiritual authority but not his temporal-political and territorial—authority.

Still, inadequate or incomplete as it may seem, the research still provides some history that describes the problems associated with recognition of authority by the communities outside of the purview of the Moroccan Sultanates. In fact, Sufi orders (or zawiyas) competed against each other for power and influence in sites opposed to the dismembered Sa'adian Empire: "the Dala'iyya in the Middle Atlas, the Samlaliyya in the Sous valley, and the Arab tribesmen in the Atlantic littoral led by al-“Ayyashi” (Bouasria 2015, 54). Moreover, between 1640 and 1686, there were Sultans all in the principal cities of Marrakesh, Fes, Meknes, Tetuan in the north (see map 4.7 above), and the Sous Valley in the south vying for the unification of Morocco. Finally, in 1664, Moulay Rashid defeated his brother Muhammad al-Sharif and within ten years was able to consolidate power throughout most of Morocco. Moulay Rashid is considered the founder of the second Sharifian reign in Morocco- the Alawite Dynasty. By 1673, his son, Moulay Ismail, had

${ }^{157}$ Some of these include Ibn Battuta (1304 -1368), Ibn Khladun (1332 -1406), Leo Africanus (1485 - 1554), Alvise Cadamosto (1432-1483), and Major Daniel Houghton (1740-1791). 
taken over and established law and order throughout most of Morocco through brutal means. He implemented a new, systematic manner of militarization; he adopted a Negro army called the 'Abid or black regiments composed of either formally or soon to be freed slaves.

Throughout the seventeenth and eighteenth 'Alawite' centuries, control by the Sultans was, for the most part, taken by force and almost never by acquiescence of the population or diplomatic means. For example, Moulay Ismail, "Sultan of Fez... of the Gharb, the Rif, and the Taza region," was able to control the Sous, not through any negotiated terms but "at the point of the sword" (Julien 1970, 248). Rebellion was common and the Sultan had to campaign throughout the southern 'territories' of Morocco between 1672 and 1687. He not only vanquished enemy leaders in Marrakesh, Fes, Taruouant, Tadla, in Dila, and other provinces in the north, but also massacred the population of entire cities such as Taroudant in March 1687. García-Arenal and De Bunes wrote that although "the policy of Moulay Isma'il [was] aimed at creating stable borders in his kingdom," especially in the east versus Algiers, he was more capable at 'preaching' a 'holy war' "against the occupying Christians of the coastal cities of his kingdom" in the south ${ }^{158}$ $(1992,141)$. In spite of the relative consolidation of Moroccan lands, Abun-Nasr admits that even after Moulay Ismail's death:

Morocco had no stable bureaucracy or recognized representative bodies that could ensure continuity in the government of the country...the existence of effective government depended on a new sultan's ability to develop the military means of having his authority obeyed...Consequently the discordant tribal constitutions of the society and the strong local particularisms plunged the country into continuous political strife and led sometimes to chaos $(1987,231)$.

It is at this point that a new political concept developed in Morocco: bilad al-siba (the lands of no authority) and the bilad al-makhzen (the lands of government). This dichotomous political idea implied that although the sultans were absolute rulers, they still only controlled part

\footnotetext{
158 Taken and translated from the Spanish by the author: "La política de Muley Isma'il está orientada a crear unas fronteras estables en su reino" and "contra los ocupantes cristianos de las ciudades costeras de su reino" in the south found in Mercedes García-Arenal and Miguel Ángel De Bunes, Los Españoles y El Norte de África Siglos XV-XVIII (Madrid: Editorial Mapfre, 1992), 141.
} 
of Morocco. In addition, the 'Sudanic' or southern Saharan lands that stretched to Timbuktu had already reneged on acknowledging the Alawi Sultan. When Moulay Rashid "was proclaimed sultan in Fez as the first ruler of the "Alawi Dynasty," the bilad al-makhzen was a realm described by Levtzion as "land effectively controlled by the central authority and, under the influence of the towns, integrated into the social and economic texture of the sultanate" $(2008,156,147)$. The bilad al-siba were "the lands...in practice, independent, but in theory, part of the sultan's dominions temporarily in secession" (Ibid., 147). Hodges, in describing the reign of Moulay Ismail $^{159}$ (1672-1727), states that the Moors used the term trab el-beidan, for "the land of the 'whites'” $(1983,9)$. The Moors, who paradoxically were of mixed origin, designated much of the 'western' Sahara as the trab el-beidan including the territory "from the Dra'a River in the north to the banks of the Senegal and the bend of the Niger, and from the Atlantic seaboard to a series of almost impenetrable dune zones...in what is now eastern Mauritania" (ibid., 8-9).

This large territory was actually in flux as the Moroccan Sultan made several attempts to control these dominions. Moulay Ismail attempted to subdue the tribes outside his influence but primarily came away with slaves, mostly black that were, in turn, set apart and integrated into his growing 'Abid army. He sent forces to Trarza (1672), led an expedition in 1679 south of the Sous, to the Adrar, and made other incursions to settle disputes among his allies or against enemies (ibid., 29). However, his allies only nominally accepted the Sultan's suzerainty in order to reinforce their own power and his expeditions were relatively short and irregular. Moreover, the acquisition of so many slaves depleted the southern oases of their agricultural manpower and decimated the sustenance "in the environs of the cities" (Laroui 1977, 274). The Sultanate seems to have had no overriding long-term "impact at all on the region now constituting Western Sahara" (Hodges1983, 30). By 1740, the ruling pashas in Timbuktu were forced to pay tribute to

\footnotetext{
159 “whose mother was a black Saharan slave.” Hodges, Western Sahara: Roots of a Desert War, 29.
} 
the Tuareg. Consequently, by the time of Moulay Ismail's death (1727), tribal rivalry renewed and a state of anarchy reigned in the southern territories of Morocco for the next thirty years.

The inability of the sultans to consolidate power (which was intermittent and based on force) among the Berbers in the mountains, the Arab tribes of the plains, and the zawaya ${ }^{160}$ brotherhoods, "whose power had increased in the course of the holy wars against European aggression on the Moroccan coast in the fifteenth and sixteenth centuries," allowed for "the decline of central authority" (Levtzion 2008, 147). Hodges wrote that "the sultans' chances of maintaining direct contact with the trab el-beidan vanished as the regions to its immediate north, the Noun, the Anti-Atlas and the southern Souss [Sus], reverted to their old status as part of the bilad as-siba" (Hodges 1983, 30). Dunn, examining the expansion of a Berber-speaking tribe called the Ait Atta or "people of Atta," originating in the "pre-Saharan belt just south of the central High ${ }^{161}$ Atlas" in the Tafilalet region, writes that the Sultan ignored this expansion as well as "populations lying directly in its path" $(1973,99)$. Dunn also reiterates Hodges' comments on the lack of Sultanate military expeditions south of the High Atlas Mountains. He further describes how "no Sultan succeeded regularly in collecting taxes or calling up military contingents south of the High Atlas" (ibid.). However, he does contrast this argument by stating that:

Despite the absence of real political authority, the Sultan did claim sovereignty over the entire western Sahara as amir al-mu'minin, or head of the Muslim community...by issuing seals and letters of investiture to local leaders and by mediating...disputes. ${ }^{162}$ Thus, local leaders sought association with the Sultan

\footnotetext{
${ }^{160}$ Centers of Sufi brotherhoods.
}

\footnotetext{
${ }^{161}$ The High Atlas Mountains compose the highest mountain peaks of the Atlas Mountain range. This section is located in south central Morocco. Directly south of the westernmost High Atlas lays the Sous River Basin. The southernmost Atlas section of peaks is labeled as the Anti-Atlas Mountains. The Dra'a River Valley runs parallel to the latter section and, along with the Sus, had been in continuous dispute for centuries over the control of these regions. South of these regions, lies the Western Sahara, which has been the focus of international controversy between the POLISARIO and the Kingdom of Morocco.

162 "In turn, most southern groups...recognized the Sultan's religious authority, believing him as a sharif, to retain the Baraka, or divine grace, which brought munificence and good fortune on the community of believers," Ross E. Dunn, "Berber Imperialism: The Ait Atta Expansion in Southeast Morocco," in Arabs and Berbers: From to Nation in North Africa, edited by Ernest Gellner and Charles Micaud (London: Duckworth and Company, 1973), 99.
} 
through political investiture... and disputing families, villages, and even tribes sent their cases to the Sultan or makhzan judges for adjudication (ibid.).

This is a debate that is rooted in the fusion of Islam over both the public and private dimensions of civil society. The Sahrawi are predominantly Muslim followers even outside the frontiers of Western Sahara proper in the camps around Tindouf, Algeria. However, based on over 25 interviews conducted in their 'refugee' camps in Rabouni, Smara, and Laayoune, the leading political and intellectual leaders of these communities have expressed openness to other faiths. They do not seem to center their national aspirations on religious governance but rather in political or temporal authority based in part on territorial sovereignty-the claim over the Western Sahara.

This divide has been of such importance that it was addressed at the International Court of Justice's (ICJ) proceedings concerning the Western Sahara in 1975. For example, the Alawite Empire was considered a Sharifian Empire because of its religious ties to the Prophet Mohammed. In presenting evidence to the ICJ, Morocco actually asked that the Court take into account the 'special' status of the "Sharifian State," based on the rule of international law that "requires the structure of a State to follow any particular pattern, as is evident from the diversity of the forms of State found in the world today" (ICJ 1975, 43-44). Morocco argued that the Sharifian State "consisted in the fact that it was founded on the common religious bond of Islam existing among the peoples and on the allegiance of various tribes to the Sultan, through their caids or sheikhs, rather than on the notion of territory" (ibid., 44). The Moroccan state pressed for the Advisory Panel to take note of the "special forms in which its exercise of sovereignty may...have expressed itself" (ibid., 44). This interpretation of national identity associated with recognition of a supreme authority such as the sultan is difficult to challenge. For instance, primordialism does allow for such a development because primordial bonds rely on objectified 
points of nationality that include religion, in this case Islam. Moreover, Morocco stated when presenting their case before the ICJ that:

"bled makhzen and bled siba [sic], merely described two types of relationship between the Moroccan local authorities and the central power, not a territorial separation; and that the existence of these different types did not affect the unity of Morocco. Because of a common cultural heritage, the spiritual authority of the Sultan was always accepted...Thus the difference...did not reflect a wish to challenge the existence of the central power so much as the conditions for the exercise of power" (ibid., 44).

Yet, these interpretations of the bilad al-makhzen and bilad al-siba were made almost three hundred years later. For despite the Moroccan claim, it would be difficult to ascertain if, in fact, the sultans of the age and the local caids ${ }^{163}$ or sheikhs actually agreed with these types of interpretive arguments. What is certain is that there was such devolution of power that it allowed for free localized rule. Accordingly, if such claims are to be accepted then nationhood is based on the influence that was bestowed through others, namely other local chieftains. This might indicate that the proper approach to understanding this type of nation building is instrumentalism. Instrumentalism considers national identity through rational means and socio-institutional practicality. For example, the sultan's rule, as determined by the Moroccan claim (in 1975), was of political behavior for governmental expediency. One may argue that the manner in which the Sultanate took shape was based on economic advantages — the Trans-Saharan trade routes—but it was primarily focused on spiritual authority - a more cultural explanation of nationhood. The political reality of the period fused not only an elitist (Sultanic) process of governanceinstrumentalism — but also Islam (already in place at the grass-roots level), a cultural, primordial characteristic of group cohesion, to produce a distinct mode of power and of course national identity.

Still, the POLISARIO does not consider this the appropriate interpretation because of the vagueness of the sultan's rule at the time. The POLISARIO insists that once they do establish a

${ }^{163}$ Caid (also spelled qaid or kaid) is the name given (in a North Africa) to a Muslim chief (or Berber chieftain), judge, or senior official. 
socio-governmental framework in the Western Sahara, their constitution would be open to all faiths. Yet, from first hand observation, it seems difficult to imagine how a Christian or Jewish convert would fare in camps where the population is predominantly Muslim. In truth, the POLISARIO have a point in maintaining that 'spiritual influence' is not a valid consideration of authority because of its subjective connotations. It is one reason why the POLISARIO and $\mathrm{SADR}^{164}$ have not grounded their social and political objectives in Islam. Currently, religion has been treated as a private matter, not to be enforced from above (Zunes 1988, 149). The issue of spiritual sovereignty is usually a topic debated among theologians as it relates to a Creator Being. However, this issue has become prominent among Middle Eastern states because of the influence of religious-leaning political parties and terrorist movements desiring to install 'Islamist States' or Caliphates. After all, the Kingdom of Morocco, although one of the more secular-leaning countries of the Middles East, is still ruled by a King who claims ties of sacred descent to the Prophet Muhammad. These religious claims necessitate a closer interpretation through the theoretical approaches of identity, which will be discussed in a later chapter.

The Central Question of this section asked if the origins of Sahrawi identity lie within this period. And if so, in what form did it materialize? If Sahrawi national identity began here, then it would still prove difficult to ascertain due to the huge flux of tribal rivalries challenging the power bases of the imperial cities and their sultans in Fes, Marrakesh and south into the Tafilalet region. More importantly, the northern part of Western Sahara proper, the Sequiet elHamra, was open to a disparity of cross migration and inconsistent suitors for power. This area included the northern belt of the Sequiet el-Hamra and the Oued Dra'a and Sous River Valleys, which currently compose the southern provinces of Morocco. Moreover, the consolidation of power involved not only politico-tribal dominance supported by physical force but also socio-

\footnotetext{
164 SADR is the acronym for the Sahrawi Arab Democratic Republic proclaimed on February 27, 1976 by the Provisional National Sahrawi Council of the Polisario Front, the Sahrawi government-in-exile that administers nonMoroccan administrative lands in the Western Sahara.
} 
religious influence through the zawiyas led by the sharifs. Of course, the most important region is the actual territory of what is today the Western Sahara. More constructivist approaches argue that the encroachment of colonial powers into west and northwestern Africa generated resistance from those long-since arrived established. Yet, the only evidence of 'colonial' resistance was as a result of the Portuguese crown's insisting that the sultans send an emissary to conclude negotiations over commercial outposts along their Moroccan coastline. This produced a staggered union of tribes joined in the ouster of the Portuguese by 1524. This aggression was inconsistent, varied, and primarily forged by the use of religious flag-waving against infidels. Monotheistic Islam did change the faith among Saharan Berbers; however, it did not profoundly change their lifestyle. Zunes explains, in his serious study of the internal governing structure of the Sahrawis that Islam did not coalesce religious and civil affairs as it did in almost all Arab countries. His interviews conducted with Sahrawis across different sectors of society demonstrated that they emphasized "the difference between true Islam (the message of the Prophet Muhammad) and the cultural traditions of societies which adopted Islam as an official religion" (Zunes 1988, 149). According to Zunes, the Sahrawis "have never known an emir or imam...were never under direct Ottoman rule," and thus Islam never became their 'state' religion (ibid.). In addition, at this time, Europeans never did gain a proper foothold in the Western Sahara.

This section demonstrates that a more organized political society among the Western Saharans developed because the sovereign entities ruling the area in this period became stronger and their control of territory expanded. Although there were many sultans and numerous tribal fiefdoms sprang up at one time, the geographical scope of the region had already diverged and produced independent histories north and south of the Western Sahara. In the most crucial of sectors such as the Sequiet el-Hamra and the Sous River Valley, questions remained until the emergence of the late Alawite Sultans as to who controlled these areas. Despite the unclear interpretation of dominion over these disputed areas north of the Western Sahara and the 
inconsistent uprisings against foreign intrusion during this period, no definitive origin for a Sahrawi nation stands out. In fact, Sahrawi identity remains difficult to establish. 
This period from 1758 until 1859 features the diplomatic peak of Moroccan and Spanish diplomacy over commerce and territory in contested areas of Morocco. This section extends the socio-historical analysis of the period in the western and southwestern Maghreb region (including Mauritania, Western Sahara proper, and Morocco), and provides insight to Sahrawi claims of separateness during this historical period. This chapter seeks evidence that sustains the primordial argument that the origins of the Sahrawi as a distinctive national people begin in this historical period. The chapter then examines the possibility that the origins of Sahrawi national consciousness developed from the social constructs of the region's socio-political environment (a combined primordial and instrumental approach). The argument proposes that Sahrawi national identity began to emerge at this historical juncture when local agents began to react to historical developments in a way that allowed Sahrawi nationalism to emerge. Finally, the chapter considers pure instrumentalism: A national identity that is created, manipulated, or embellished directly, subtly, or indirectly by 'ethnic entrepreneurs' for solely economic or political objectives. The continuing central question remains: do the origins of Sahrawi identity lie within this period, and through what socio-political mechanisms does it materialize?

The primordial notion, continues to be relevant to this chapter even though the analysis begins in the eighteenth century. Still, problems recur about the modern interpretation of national identity. Primordialism seeks origins of identity in the historical past but it is not a popular concept today. It also identifies national characteristics of identity within objective ethnic or cultural parameters. However, there is no standard point of origin for national identification because it is contingent upon the group in question. Because one not only lives in the modern world, but also reads and studies modern scholarship, the more inclusive, constructivist approach to nationality has prevailed. Constructivists argue that the emergence of national identity is 
arbitrary and subjective in selecting a point of origin, and discuss the interaction of structural realities and the agency of ambitious politicians or nation-builders to select any point of origin. Constructivism also conforms to the dictates of our modern age in that it enhances our understanding of identity politics by fusing instrumentalism and primordialism - two streams of thought that some suggest are largely dated and unpopular.

Despite its scholarly unpopularity, it is not an easy task to dismiss primordial concepts. This segment in history is still being studied, revised, and re-told. In addition, countries continue to form based on nationalities seeking autonomy, secession ${ }^{165}$ or outright independence. Several collectivities or minority groups within other countries or territories persist even today in seeking more autonomy or recognition by other powers as legitimate, independent political entities (the Palestinians, Kurds, Catalans, and the Naga as examples). They distinguish themselves by pointing to what they believe are objective cultural or ethnic markers. They remark on their history.

In this chapter, the constructivist approach, where the encroachment of foreign powers into west and northwestern Africa generated resistance and a more organized political society among the proto-Sahrawis, will become much more significant. Constructivist explanations rely on a more fluid understanding of the emergence of nationalities, for it allows an identity to be approached from below. This would be the level of the common citizenry, a grass-roots level, where arguments are made for given and objective attributes that can only be described as affinities or attachments to family or tribe, the land, and links to tradition (custom, ancient myths). It also allows for identity to be studied from above. It seeks explanations of nationhood either from geo-political dynamics and circumstances that have influenced the citizens or the manipulation either directly or indirectly from elitist or 'ethnic' entrepreneurs. After the socio-

\footnotetext{
${ }^{165}$ Secession is noted as a different category from independence because it involves seceding from a territory and possible willingly being annexed by another territory - an irredentist form of autonomy. Instead, independence is actively engaging in an independent country enterprise.
} 
historical description and commentary of the Sahrawi during this period, a critique concludes this section.

\section{The Sharifian Age (1758 - 1800)}

The chronology below mentions numerous tribes, which only make ancestral arguments even more convoluted. Independent tribes had taken control of the vast greater Western Sahara, south and southwest of Morocco. This section, therefore, highlights a more concrete feature of national identity-territory. The Sahrawi claim they have never historically submitted to any type of territorial control. This 'rebellious' attitude in asserting that the Western Sahara had always remained outside the influence of any sultan is an important part of Sahrawi national identity. This section also underscores the precarious position of the sultans and the regional independence of the many competing tribes not only within the fledgling 'Moroccan Empire' but also outside its frontiers. If direct ancestry to the modern Sahrawi remains elusive perhaps this feature of their identity is more apparent. In 1757, Sidi Muhammad Ibn 'Abd Allah (1757-1790), or Sidi Muhammad III, took the reins of power in Morocco, but had not made incursions deep into Western Sahara proper. Julien notes in his History of North ${ }^{166}$ Africa, Sidi Muhammad, as with previous sultans, had trouble extending his power and controlling even the unruly populations within his 'Moroccan Empire.' Several independencies sprang up to the south and east of the High Atlas 'domains' of Morocco. Julien states that the "unsubjected zone remained very extensive and the sultan spent a great part of his reign in putting down revolts and stemming encroachments by the Sanhaja in the Middle Atlas" (Julien 1970, 264). These principalities had already begun falling away from the direct control of Sultan MoulayIsmail in the late seventeenth and early eighteenth centuries. Sidi Muhammad III's subsequent

\footnotetext{
${ }^{166}$ Moulay is also spelled Mawlay, or Mulay in the Maghreb and Andalucía. In Morocco it refers to descendants of Muhammad. John L Esposito, Oxford Dictionary of Islam, s.v. "Mawla," (Oxford: Oxford University Press, 2004).
} 


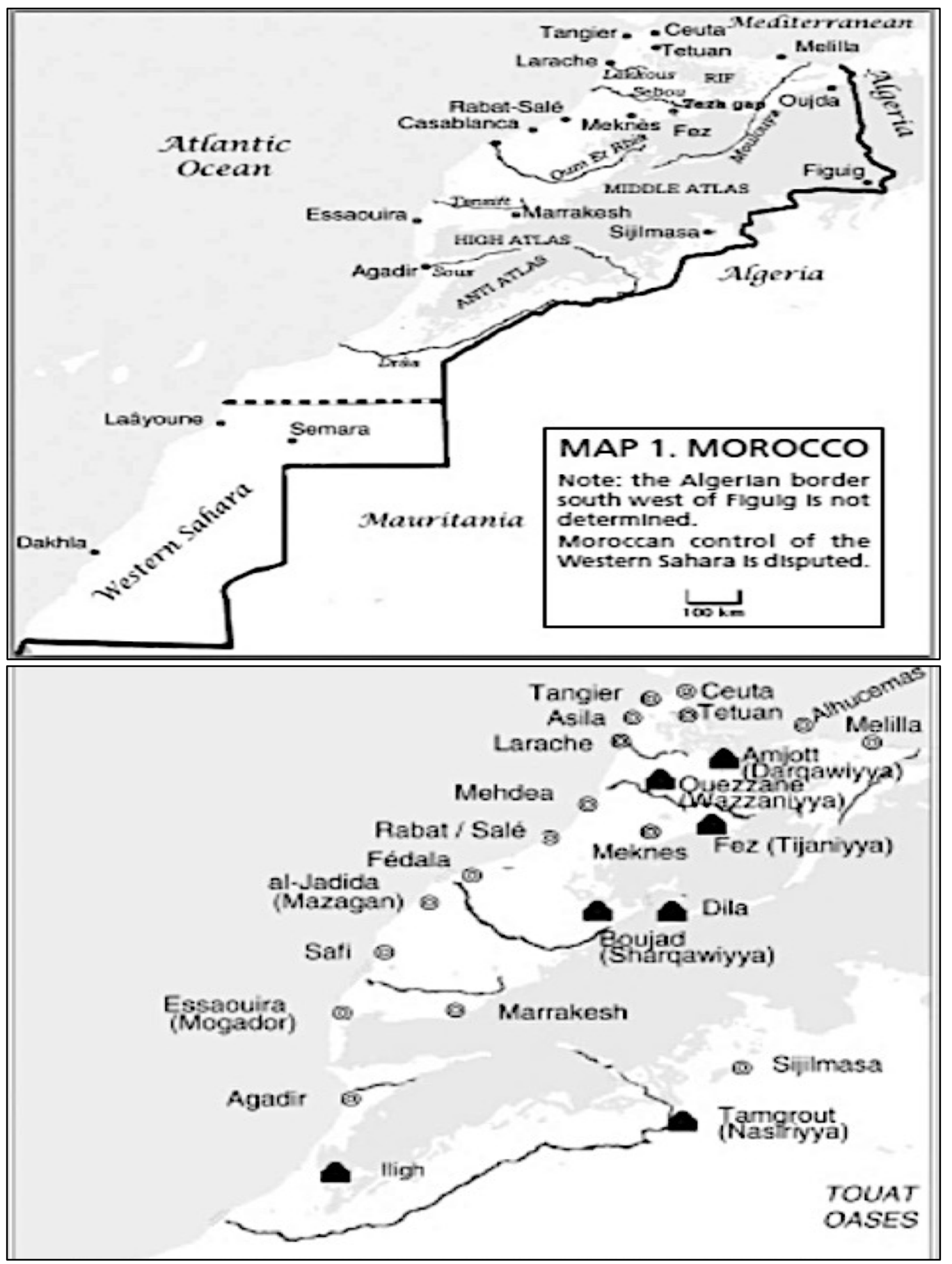

Maps 5.1/5.2: Comparison of Modern-Day Morocco (above) with 'Morocco,' in $1600-$ $1822^{167}$

167 The maps above compare of the modern state of Morocco to its nominal extent of influence in the seventeenth through early nineteenth centuries. The map below shows its fluid 'frontiers' extending until the Oued Dra'a (south of Iligh stretching northeast and then north) to its south but not to the whole of modern Western Sahara. South of the Oued Dra'a there remained various independent tribal confederations. The maps do not show other independent tribes in the 
aggressive policies executed by his ' $\mathrm{Abid}^{168}$ army and his alteration of the trans-Saharan trade routes for more control dissatisfied many competing groups in the region. Sidi Muhammad had created a new Atlantic port called Mogador (Al-Sawira) ${ }^{169}$ to serve as the entry point for trade to the south, bypassing Sijilmasa ${ }^{170}$ and the Tafilalet region, controlled by other leaders. The city of Mogador at the southern fringes of Morocco deprived the Sous (and its inhabitants) "of its former maritime outlets, grew poor and ceased to be a centre [sic] of rebellion and a threat to the authority of the makhzan ${ }^{171 "}$ (Julien 1970, 266). Nevertheless, the loss of control along these trade routes ${ }^{172}$, internal volatility within the 'Empire' itself, and the lack of stability in Timbuktu led to a high level of insecurity "for trans-Saharan traders" (Lydon 2009, 97). The net result of these policies did not extend his reach south of the Sous River Valley and modern Western Sahara remained mostly outside of the Sultan's influence.

deep south into modern Mauritania and northern Mali. Maps adapted from C.R. Pennel, Morocco: From Empire to Independence, eBook Edition (London: One World Publications, 2013), 14, 55.

168 'Abid comes from the term 'abid al-Bukhari, meaning servants of al-Bukhari, which were the Sultan's army of Saharan blacks recruited and sent to a special camp at Mechra' er-Remel to propagate and their children at the age of 10 were then presented to the Sultan and trained to become fighters in his army. Encyclopedia Britannica, $15^{\text {th }}$ ed., s.v. "al-Bukhari."

${ }^{169}$ Mogador had also replaced the coastal commercial port of Agadir and is known today as Essaouira.

${ }^{170}$ Sijilmasa, which had been the primary trans-Saharan trade hub (primarily for gold) for more than 650 years (757 $\mathrm{AD}$ to its first abandonment in the 1390s), was a stopping point for caravaners travelling southward, especially to Timbuktu, had been reconstructed by Moulay Ismail but again was destroyed by the nomadic Ait Atta Berber tribes moving northwest in to the Tafilalet and Dra'a Oases. James Miller, "Trading Through Islam: The Interconnections of Sijilmasa, Ghana and the Almoravid Movement," in Julia Clancy-Smith, ed., North Africa, Islam and the Mediterranean World: From the Almoravids to the Algerian War, (Portland, OR: Frank Cass Publishers, 2001), 29.

${ }^{171}$ Makhzan or Makhzen is defined as the traditional central government and in this case the central administrative government of the Sultan of Morocco. Ernest Gellner and Charles Micaud, eds., Arabs and Berbers: From Tribe to Nation in North Africa, London: Gerald Duckworth and Company, 1973), index page 445.

172 Despite much evidence depicting a hard to control, peripheral Morocco under Sidi Muhammad, Lydon states that Sidi Muhammad III "ushered in a peaceful political climate favoring the expansion of international commerce." Ghislaine Lydon, On Trans-Saharan Trails: Islamic Law, Trade Networks, and Cross-Cultural Exchange in Nineteenth Century Western Africa. (Los Angeles: Cambridge University Press, 2009), 99. Of all the sources used from this period, Lydon seems to be among the few who portrays Sidi Muhammad positively in terms of improving trade in the region. 
The infusion by imperial rivals - the Ottoman Empire encroaching from the east and southeast of Morocco, the Spanish, French, and British infringing on Morocco's southwestern coasts then southward parallel to the Senegal River-along with the earlier collapse of the Songhay Empire, and the loss of reach by Morocco over its outer dominions "increased the margin of maneuver for regional groups" (McDougall 2012, 86). For example, a "charismatic Sufi and powerful entrepreneur," Shaykh Sidi al-Mukhtar bin Ahmad al-Bakkay, represented the scholarly Kunta ${ }^{173}$ tribe which formed the main part of the Sufi Qadiriyya brotherhood ${ }^{174}$ in western Africa (Lydon 2009, 97). By the late eighteenth century, this group (along with other branches of the same brotherhood) controlled the main oases and therefore the caravanning traffic from the Western Sahara to the Adrar, east to Tawdenni and the Azawad region, and south to Timbuktu (see map 5.3). Aziz Batran labeled this 'a holy economic empire,' while Lydon described the power of the Kunta as one where they "established regional order of a kind that had not been known since the fall of Songhay" and succeeded "in filling a political vacuum in the region" (Ibid, 98). Moreover, McDougall asserts that from the:

Late sixteenth through the late eighteenth centuries in the southern Sahara and the Sahel can be seen as a dynamic period of both fragmentation and recomposition, with the appearance of new power centers controlled by emerging social groups and a proliferation of new states: ....arma ${ }^{175}$ viceroyalty of

\footnotetext{
173 "The Kunta are neither a 'tribe' nor a confederation but rather family groupings... who have acquired a great religious reputation, considerable wealth" ... "dispersed throughout" the Sahara between the Atlantic Ocean and Niger. Aziz A. Batran, "The Kunta, Sidi al-Mukhtar al-Kuntī, and the Office of Shaykh al-Tarīqa 'l-Qādiriyya," in Studies in West Islamic History, Vol 1: The Cultivators of Islam, edited by John Ralph Willis (New York: Routledge, 1979), 127. "The great tribe of the Kunta, who are distinguished by their purer blood and by their learning above almost all the tribes of the desert." Heinrich Barth, Travels and Discoveries in North and Central Africa: Being a Journal of an Expedition Undertaken under the Auspices of H.B.M.'s Government, in the years 1849-1855, Vol III (New York: Harper and Brother Publishers, 1859), 686.

${ }^{174}$ A powerful Sufi movement led by the Bakkay branch of the nomadic Kunta "in the early part of the seventeenth century" would emerge "in a large region extending from the northern oasis of Tuwat, the regions of Tiris and Zemmur, over to the Taganit and the Hawd and into present-day Senegal. Eventually, one family came to settle in the Azawad region, to the north of Timbucktu, in the mid-seventeenth century, and shortly after, Kunta relatives would follow." Lydon, On Trans-Saharan Trails, 2009, 97.

175 The arma are a people of traditionally Moroccan descent from the toppling of the Songhay Empire that still survive today in and around Timbucktu.
} 
Timbucktu and Jenné and the emergent Tuareg confederations that pressed upon it from the north" $(2012,86)$.

This regional order outside the purview of the Moroccan Sultan, moved among the trans-Saharan trade in salt, tobacco, slaves, camels, gum, and book manuscripts among other items. These regional power centers would begin to revolve around confederations of tribes such as the Tekna, Reguibayt, Kunta, Tuareg and other sub-tribes ${ }^{176}$. In addition, "embryonic supratribal" groups would produce the independent nomadic Emirates of Trarza, Brakna, and later in the Adrar, in the deep southwestern Sahara (see map 5.1) and south central regions of Western Sahara proper respectively (Lydon 10; Hodges 1983, 31).

The late eighteenth century was marked by a high level of independency among several groups. These groups had forged a tribal identity. These identities had not coalesced with, and were separate from those of, the 'Empire of Morocco.' Muhammad III's empire also was not a homogenous political entity that was composed of several tribes and these were associated with several 'kingdoms' that were themselves composed of several tribes: 1) Kingdom of Fes; 2) Kingdom of Marrakesh (Morocco); 3) Kingdom of the Sous; 4) and at times the Royalty of Sijilmasa. The southern tribes that were independent of these fiefdoms were composed mostly of confederations that maintained an identity loyal to the tribe and trickled down to the clan. The assessment at this juncture makes it difficult to isolate a confederation or tribe associated with one of Sahrawi descent.

Lydon mentions that "the region of the western Sahara, stretching south of the $\mathrm{Wad}^{177}$ [or Oued] Nun to the Senegal River, was now dominated by Saharans of mixed ancestry who chose as their identity marker...the ethnonym bidan," which will be discussed later (ibid., 10). For

\footnotetext{
176 Other tribes such as the Arosien, Oulad (or Awlad, which is defined as descendants or sons of) Delim, Oulad Tridrarim, and the Oulad Bu Sbaa also are considered Sahrawi today but are mainly of Arabic extract.

${ }^{177}$ Wad or Wadi is a transcription of the word Oued that is used across the Middle East, in general, for the name of a river valley. However, in the Maghreb, this term Oued is applied to a river or riverbed even if dry for most of the year. Oued will be utilized in this work because it is more commonly found in the literature as such.
} 


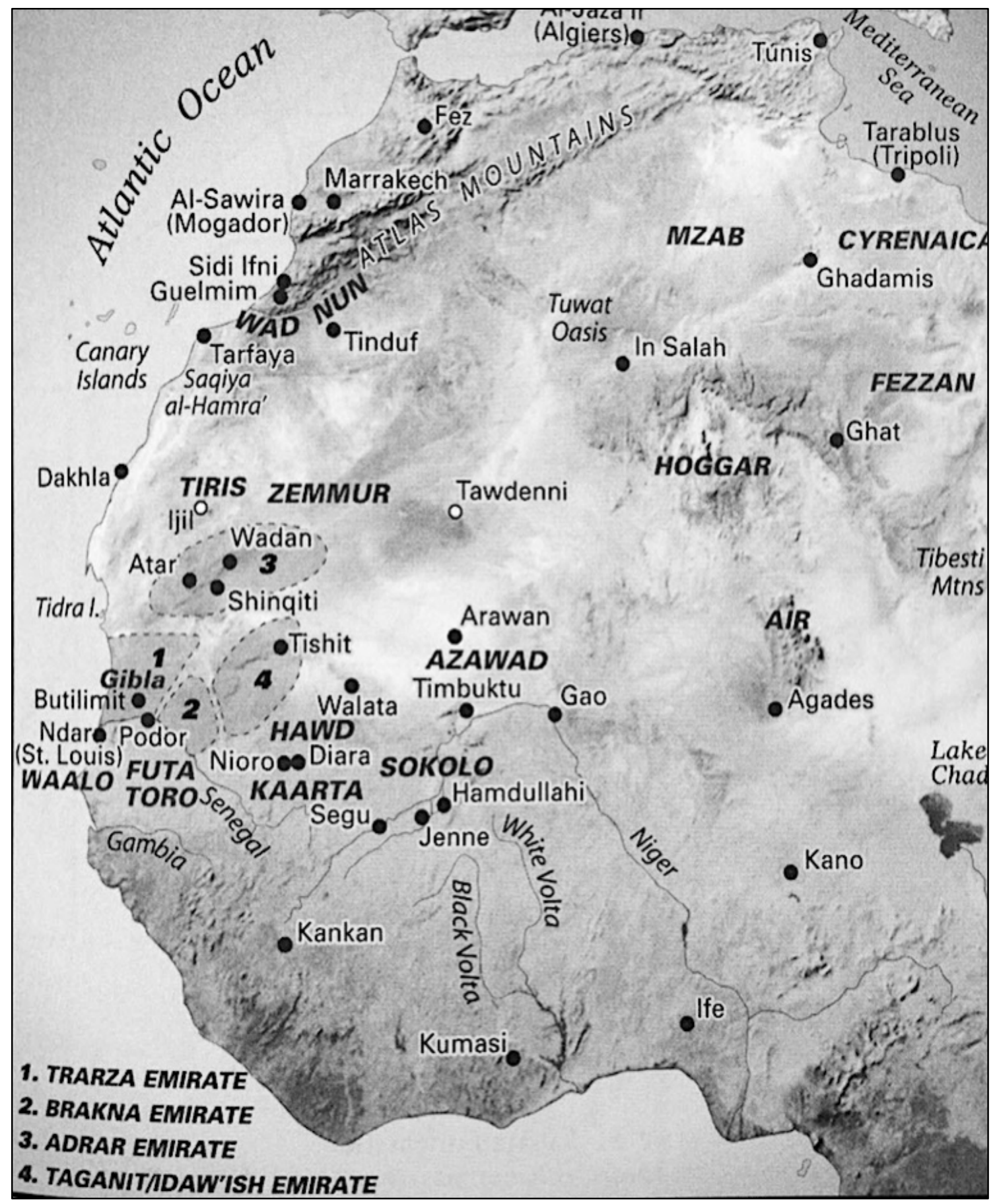

Map 5.3: Socio-Political Environment of Northwest Africa ${ }^{178}$

${ }^{178}$ Map titled "Western Africa," from Lydon, On Trans-Saharan Trails, 2009, xxiii. 
instance, The Tekna are "thought to be a product of a fusion of Lamta [Sanhaja] Berbers" and the Beni Hassan branch of the Maqil Arab Bedouins. They had arisen to live between the southern Anti-Atlas Mountains and the Sequiet al-Hamra (see map 5.3 as Saqiya al-Hamra') (Pazzanita 2006, 406). The Reguibayt, the most known and influential of all tribes in the Western Sahara, are thought to be of Sanhaja extraction as well. Its founder, Sidi Ahmed Erguibi, travelled from Fes to the Dra'a River Valley but moved further south, inland, to escape the "depredations" of both the Europeans, "then present on the coast," and the Maqil Arabs (ibid, 364). The Reguibayt became more prominent in the early nineteenth centuries and later had a "series of ghazzis" (or tribal raids) with the rival Tadjakant tribe for the control of Tindouf ${ }^{179}$ (now part of modern-day Algeria) (Ibid). Moreover, Trout mentions that the Emirates that flourished in southern Mauritania received no type of investiture from Moroccan authority and the Adrar fell into internecine warfare in the 1740s. These areas were clearly outside of Moroccan control. Although these regions remained free of Moroccan control, they also remained independent of each other. Despite Sahrawi claims of Tekna or Reguibayt ancestry, there is no definitive proof. In fact, the only possible claim is that the Sahrawi are descendants of a multitude of tribes who, at the time, did not identify themselves as part of a great Saharan nation but to the local tribe.

\section{Contested Treaties}

European encroachment on the northwestern and western coasts of Africa had become aggressive. By 1757, Sidi Muhammad III had rebuilt the Alawite Empire, but questions were still

\footnotetext{
179 Tindouf is the Algerian city closest to the Sahrawi 'refugee camp' communities. It serves as the entrepôt for not only goods and services for the Sahrawi population today, but also for international visitors such as researchers (including the author of this work), journalists, and diplomatic officials, on their way to visit with POLISARIO/SADR representatives. It is approximately $30 \mathrm{~km}$ from the principal Sahrawi Rabouni 'city' (mostly referred to as a camp). While the POLISARIO receives most of its visitors at this site and its governmental functions operate from this 'camp,' the official provisional and administrative capital for the POLISARIO government - the SADR (Sahrawi Arab Democratic Republic) - is located inside the "liberated zone" of Western Sahara proper in Bir Lehlu. Bir Lehlu (or Lahlou) was where the POLISARIO first established the government of the SADR. SADR, http://www.arso.org/030.htm, Text of the Proclamation of the First Government of the Saharawi Arab Democratic Republic, accessed June 12, 2015, http://www.arso.org/03-1.htm, 27 February 1976.
} 
unanswered about the actual control of southern and southwestern frontiers. The research of the area at this time turned to evidence of recognition to established authority either of the Sultan or of other foreign powers in the Western Sahara. This type of information was sought in the Spanish national archives. Preliminary research established that the Spanish Monarchy had arranged and ratified treaties with the Kingdom of Morocco beginning in the late eighteenth century. Even though Britain, Germany, Italy, and Portugal had begun diplomatic exchanges with the Sultans in order to pursue commercial enterprises on the west African shores, only France and Spain had gained enough experience to produce signed treaties. Spain would maintain and begin colonization of the territory in question as France gained much more influence in Algeria and south on both side of the Senegal River.

Here, these treaties are explored to establish whether or not the Moroccan sultan controlled the territory that we now call "Western Sahara" in the late eighteenth century. It will also verify if POLSARIO claims that the descendants of the Sahrawi were never controlled by a Sultan are true. One of the first of these documents was the Treaty of Marrakesh, signed by Sultan Muhammad III and on behalf of -King Charles III of Spain, the Admiral Jorge Juan y Santacilia $^{180}$ in 1767 . This document, cited in the 1975 International Court of Justice (ICJ) Advisory Opinion, became a subject of controversy surrounding its interpretation. Its words have become an item of contention for both the POLISARIO and the Kingdom of Morocco. The English translation of Article 18 from the Tratado de Paz con Marruecos (or Treaty of Peace with Morocco) ${ }^{181}$ originally written in both Arabic and Spanish is as follows:

\footnotetext{
${ }^{180}$ Jorge Juan y Santacilia was a famous admiral in the Spanish Navy, who was designated by Charles III of Spain, ambassador extraordinaire to the court of the Moroccan Sultan Muhammad III in November of 1766. Armando Alberola Romá and Rosario Die Maculet, "El Autor: Jorge Juan Santacilia-Marino y Científico (Perfil Biográfico)," Biblioteca Virtual Miguel de Cervantes, accessed June 2015. http:/www.cervantesvirtual.com/portales/jorge juan santacilia/autor biografia/.

181 The following quote is taken from the Spanish and translated by the author: "S.M.I. [Su Majestad Imperial] se aparta de deliverar [deliberar] sobre el establecimiento que S.M.C. [Su Majestad Católica] quiere fundar al Sur del Rio Non, pues no puede hacerse responsable de los accidentes ò desgracias que sucedieren, à causa de no llegar allà [allá] sus Dominios, y ser la Gente que Havita [habita] el Pais [País] errante y feròz [feroz], que siempre ha ofendido y
} 
His Imperial Majesty deviates from discussing on the venture that His Catholic Majesty wants to start south of the River Non (Nun) [emphasis added], for he cannot be held responsible for any accidents or misfortune that would occur since his dominions do not reach there, and because the people who inhabit the Country are fugitive and fierce, who have always offended and imprisoned the Canarians ${ }^{182}$. From north of Santa $\mathrm{Cruz}^{183}$ (emphasis added) [,] His Imperial Majesty grants to them [the Canary Islanders] and the Spanish fishing, without allowing any other Nation to conduct [fishing] anywhere on the coast, which will be left entirely for them (Convenio con Marruecos, 1767).

This passage was debated between the parties to the conflict in 1975 at the ICJ. On the one hand, Spain has argued that their wording "constitutes a disavowal by the Sultan himself of any pretensions to authority in that region." 184 On the other hand, Morocco's Arabic text is worded as follows:

His Imperial Majesty warns the inhabitants of the Canaries against any fishing expedition to the coasts of [Oued] Noun [sic] and beyond (emphasis added). He disclaims any responsibility for the way they may be treated by the Arabs of the country, to whom it is difficult to apply decisions, since they have no fixed residence, travel as they wish and pitch their tents where they choose. The inhabitants of the Canaries are certain to be maltreated by those Arabs (Western Sahara [ICJ] Advisory Opinion 1975, 50).

Both Morocco and Spain claim that these interpretations are authentic. Morocco insists that their "Arabic text is the only 'official text' and should have preference" (Ibid). The words that I have italicized are the most contentious of the text. They 1) They imply that the Sultan had little demonstrable power over these areas, but 2) they indicate beyond what geographical point the Sultan intended to give the Spaniards permission for commercial fishing. The point here is not to

apricionado [aprisionado] à los Canàrios [Canarios]. De S. ${ }^{\text {ta }}$ [Santa] Cruz al Norte S.M.I. concede à estos y a los Españoles la Pesca, sin permitir que ninguna otra Nacion [Nación] la execute [ejecute] en ninguna parte de la Costa, que quedarà [quedará] enteramente por aquellos." Convenio con Marruecos 28 Mayo, 1767, Tratado de Paz con Marruecos, Estado 3372, Carpeta \#11, Número 1 y 2, Archivo Histórico Nacional de España, Madrid. See ICJ English translation in "Western Sahara, Advisory Opinion of 16 October 1975," International Court of Justice, Reports of Judgments, Advisory Opinions and Orders, 1975, 50.

${ }^{182}$ Also known as Canary Islanders.

${ }^{183}$ Spanish for Holy Cross.

184 “Western Sahara, Advisory Opinion,” 50. 
re-adjudicate a legal issue that has already been methodically treated, but to highlight the problem of interpretation that both sides use to as markers for identity

The overriding subject of this work is national identity. However, identity or identity politics is only a portion of the complex series of sub-themes within international affairs. The communication of ideas, documented or undocumented, is also an important part of global politics. At this juncture, the case introduces the communication of documentation that concerns questions of governance. Thus, the communiqués in this chapter combine both the concept of national identity with publicly written statements on the course of action that may lead to answering the questions of governance - that is, which entity will govern the Western Sahara.

This is true not only for the 1767 treaty, but also for the long history of agreements among Spain, Morocco, and other foreign powers. For example, the 1799 Treaty of Meknes between Spain and Morocco apparently confirms the previous agreement set in the 1767 accord. Yet, Morocco refers to their original, more 'official,' interpretation of the Arabic 1767 text. Article 29 of the Meknes Treaty makes a background reference to His Moroccan Highness' previous offer to a certain reduction of commercial tariffs "if this grace will take place, provided that such port opens," 185 directly referring to the Barbary port of Santa Cruz (Tratado de Paz 1799). Thereafter, article 35 of the same treaty, under the title of 'Fishing,' reads ${ }^{186}$ that "[ $\left.\mathrm{t}\right] \mathrm{o}$ the inhabitants of the Canary Islands and to all classes of Spanish His Moroccan Majesty concedes the right of fishing from the Barbary port of Santa Cruz to the North" (ibid). This reiterates the fishing opportunities granted by the Sultan to the Spanish from Santa Cruz northward. Yet, article

\footnotetext{
${ }^{185}$ Taken from the Spanish and translated by the author: "Hallándose cerrado en el dia [día] el puerto de Santa Cruz de Berbería, no puede tener efecto la oferta que S. M. [Su Majestad] Marroquí tiene hecha anteriormente á la España, de que sus vasallos disfruten la baxa de un treinta por ciento sobre los derechos que satisfacen las demás Naciones; pero sí tendrá lugar esta gracia siempre que dicho Puerto se llegue á abrir" in "Tratado de Paz, Amistad, Navegación, Comercio Y Pesca, entre S. M. [Su Majestad] Cat. [Católico] Y S. M. Marroquí concluido y firmado en Mequínez á 1 de Marzo de 1799," Tratado con Marruecos, Artículo XXIX, Madrid: La Imprenta Real. Archivo Histórico Nacional de España, Estado, Legajo 4350, No. 1 (Caja No.1).

${ }^{186}$ Taken from the Spanish, "Á los habitantes de las islas Canarias y á toda clase de Españoles concede S. M. [Su Majestad] Marroquí el derecho de la pesca desde el puerto de Santa Cruz de Berbería al Norte.” Ibid., artículo (article) XXXV.
} 
35 in 1799 contradicts the passage from 1767. In 1799, they refer to different directions being conceded from the point of Santa Cruz. Still, the first article of the Treaty of Meknes ${ }^{187}$ begins: "[t]he Treaty of 1767 , the Convention of 1780 , and the 1785 Agreement in all that is not contrary to the present [1799] Treaty is renewed and confirmed" (Ibid). Overall, despite the small contradiction, these documents seem to indicate that the Sultans were willing to give Spain control over certain territories, either within or outside of their control, for the construction of a port and fishing rights adjacent to Santa Cruz. These interpretive debates over the wording and then meaning of terms in public documents stem from the translation of the treaties above. However, meaning can also be debated over less official documentation and more so over demographic expressions of the period. For instance, in the previous chapter, the concept of bilad al-siba was introduced as the region of unruliness. Julien writes that after the reign of Sidi Muhammad up until 1912, "the country was divided into two sections, the bled-makhzen, more or less obedient to the ruler if he was a man of energy, and the bled al-siba, itself rent by tribal rivalries but always obstinately resistant to the sultan's authority" (270). Bilad al-siba, the part of the desert that did not fully accept the Sultan as supreme ruler, has traditionally also been known by the expression trab al-bidan. Trab al-bidan or land of the whites, in contrast to al-sudan or land of the Negroes, was an Arabic term that racially divided the African population. The term has been associated with the Hassaniyya-speaking population in the Western Sahara region that includes Mauritania, the Tarfaya Strip ${ }^{188}$ in southern Morocco, the Tindouf region in Algeria,

\footnotetext{
187 Taken from the Spanish and translated by the author: "Se renuevan y confirman el Tratado del año de 1767, el Convenio de 1780, y el Arreglo de 1785 en todo lo que no sea contrario al presente Tratado.” Ibid., artículo I.

${ }^{188}$ Tarfaya Strip - At the end of the 19th century, the Scottish entrepreneur Donald Mackenzie persuaded the Governor of Sous, Muhammad Bayruk, to cede him a strip of land on which to establish a trading post. Known as Tarfaya strip or Cape Juby strip, (roughly three km wide and $12 \mathrm{~km}$ long), Mackenzie built Port Victoria, a trading post/factory, which he managed through his own North-West Africa Company, hoping to capture a portion of the caravan trade. "'Casa del Mar' Fortress," in Sharing History: Arab World-Europe 1815-1918, http://www.museumwnf.org/, Museum With No Frontiers, 2015, $\quad$ accessed $\quad$ June $\quad 12, \quad 2015$, http://www.sharinghistory.org/database item.php?id=monument;AWE;ma;21;en\&pageT=N.
} 


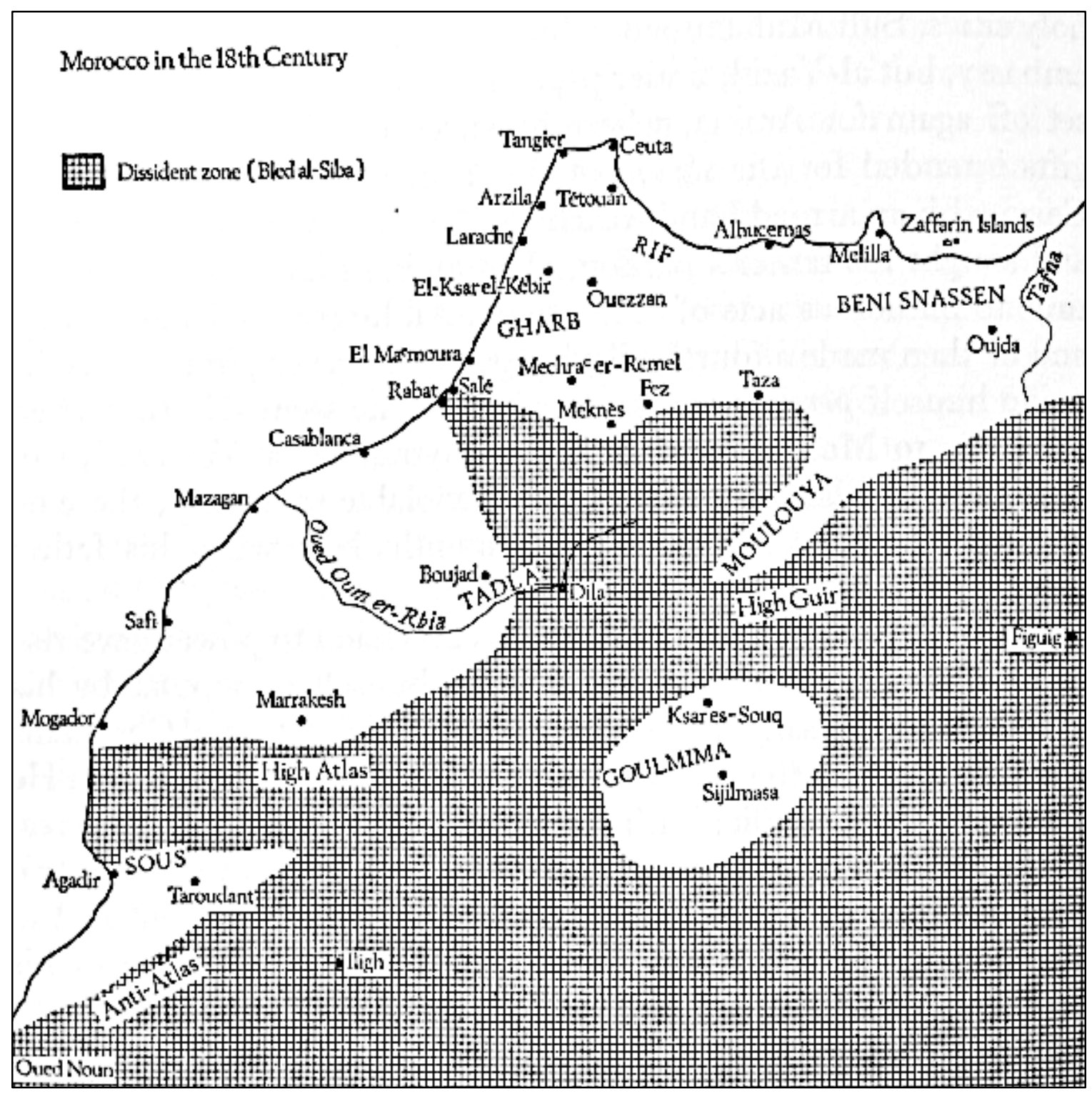

Map 5.4: Morocco in the Eighteenth Century ${ }^{189}$

parts of Niger and a small strip of Mali (Lakhal et al 2006, 5; San Martin 2010, 589; Deubel ${ }^{190}$ 2011, 3).

In several of the interviews, the author posed the question to many members of the POLISARIO if they could describe what is the origin of their identity. The current representative

\footnotetext{
189 Julien, History of North Africa 1970, 268.

${ }^{190}$ Deubel also suggests that only in Mauritania are they called Maures.
} 
of the SADR in Washington, DC, Yeslem Beisat, stated that they were a mix of people-Berber, Arab, and Black - and seem to be proud of this fact. ${ }^{191}$ They also believe that part of their identity stems from the heterogeneity of tribes and races as well as never submitting to Moroccan Sultanic rule. For instance, Muhammed Omar, my translator and guide while interviewing the various members of the SADR vanguard, stated that the Sahrawi knew "ni Satan ni Sultan" (neither Satan nor Sultan). ${ }^{192}$ The development of a distinct Arabic Hassaniya dialect adds to these layers of distinction. These layers of identity: 1) For the first time, Moroccan leaders admitting to outsiders that they did not really control the area now known as "Western Sahara"; 2) the mixture of tribes in the Oued Dra'a, south of the Oued Nun into the deep Sahara; 3) the rise of autonomous tribal entities across the Nun, Sous, and Sequiet al-Hamra River valleys, separate these groups from those living under the sovereignty of the Sultan. These distinctions seem to be part of modern Sahrawi identity. Yet, it still proves challenging, even with these distinctions, to derive from any one tribe, a direct line of ancestry to the Sahrawi even as we approach the nineteenth century.

The Lands of 'Dissonance' and of the 'White Moors'

This section introduces the concepts of 'bilad as-siba' and the 'bidan.' Bilad as-siba added to the growing notion that a divide was evident between those territories ruled by Morocco (bilad almakhzen) and those that were not. Bidan characterized those populations who were not of black African origin but were 'white.' Despite their usage in the late eighteenth century, bilad almakhzen and bilad al-siba are still under heavy scrutiny today. Bilad al-makhzen has been predominantly understood as the areas that were under the full control of the Sultan. What is the significance of and why stress these groups of words now? First, these expressions have become

\footnotetext{
${ }^{191}$ Mohamed Yeslem Beisat, SADR ambassador to the United States, interview by author, Washington DC, November $11,2013$.

${ }^{192}$ Mohammed Omar, Deputy Minister of Public Relations, interview by author in Rabouni Camp outside of Tindouf, Algeria 02 October, 2014.
} 
even more relevant today as a result of more anthropological and political discussion over the origins and composition of North African identity. The research, which is still in its infancy, about the early origins of the Saharan population may contradict the traditional views of many tribes who claim Arabic ancestry and direct lineage to the Prophet Muhammed. Second, as it relates to the Western Sahara dispute, usage of the terms has been used to add and dismiss Sahrawi national identity. Third, these concepts agree with the type of discussion at this juncture of history because they play an important role when foreign powers begin formal colonial administration of areas not under the Sultan's control.

Bilad al-siba is generally accorded the definition of "land of dissonance" or autonomy (López Bargados 2003, 598; Pazzanita 2006, 56). Despite the agreed upon meaning, Morocco has applied al-siba to defend the annexation of the Western Sahara. Morocco will argue that despite being administered by independent caids and where "taxes were not paid," these sovereigns of these lands "were appointed by royal decree" (Pazzanita, 56). The caids would be given 'authority' over these peripheral territories on behalf of the Sultan of Morocco. The Sahrawi argue that these are ambiguous claims because: 1) Many Saharan tribes travelled between both areas of the makhzen and al-siba making the exercise of proper rule by anyone difficult; 2) Although several independent tribes acknowledged the sultan's spiritual authority, he did not command temporal authority; and finally 3), Due to harsh climatic conditions "in the territory....along with a near-total lack of" urbanization "in pre-colonial Western Sahara...in contrast to what is now southern Morocco... a status of bilad [al]-siba, let alone bilad al-makhzen, never existed in the Western Sahara" (ibid).

Trab al-bidan or the bidan has been described as an 'imaginary collective' (Ould Mohamed 2010, 236), a region that by the turn of the nineteenth century began to take shape identifying a divide from the 'white' Hassaniyya-speaking Arabs "from the neighboring regions to north and east, where Berber languages...remained dominant" (Hodges 1983, 11). The term is 
traced to early Islamic geographers, conquerors, and European explorers. Norris confirms this notion by writing that bidan: 'Meaning 'the whites,' is found in quite early writings. According to La Courbe (1685), 'The Senegal [River] separates the Azoaghes (Zenagah), Moors or Bazanez (Bidan), from the Blacks; so that on one side of the river are Moors, rather white than black; and on the other, men perfectly black" (Norris 1986, 245). Still, the term of trab al-bidan has been discussed by many North African scholars in comparison with several other terminological references -1) al-sib, 2) ahrar, 3) al-sudan, 4) haratin, and 5) 'abid—for more ancient populations that lived in northwest Africa, especially in the Sahara). These words are Arabic references that mean the unruly (region), free one, dark one, freed slave, and servant or slave, respectively.

Terminological chaos becomes even greater with the infusion of the primary colonial languages-Spanish and French. For example, the English term 'Moor' is a label that came to designate Arabic and Berber-speaking groups who migrated from North Africa to the Iberian Peninsula. The Spanish changed it to Moro, while the French adopted the term and changed it to mean Maure. Yet, some scholars believe that this wording may have ancient Latin (Maurus) or even Greek (Mauron) ${ }^{193}$ roots. Despite the nomenclature and the linguistic ambiguities, the phrase of trab al-bidan will be used in agreement with López Bargados' statement after explaining these troubling nuances of group identity. He writes, "in this sense, the designation Trab al-Bidan will include all Hassaniya speakers equally, irrespective of their status, adopting as an index for inclusion the fluency or competency in that Arabic dialect, and not the status that each determined social group holds"194 (López Bargados 2003, 117). One primary source that is given for this term is an Islamic Saharan scholar, poet, and jurist from the Gibla region in what

\footnotetext{
193 This Greek form of Moor was a Roman derivative of Mauri, which was the name given to the ancient Berber Empire of Mauretania and consequently lends its name to the modern country of Mauritania.

${ }^{194}$ Taken from the Spanish and translated by the author: "En este sentido, la denominación Trab al-Bidan incluirá por igual a todos los hablantes de hassaniyya, sea cual fuere su estatus, adoptando como índice de inclusión el manejo o competencia en ese dialecto del árabe, y no el estatus que posee cada grupo social determinado." Alberto López Bargados, Arena Coloniales: Los Awlad Dalim ante la Colonización Franco-Española del Sáhara, Barcelona: Edicions Bellaterra, 2003. See Chapter 3, note no. 83.
} 
should be present-day Mauritania, Sheikh Muhammad al-Mami (1792-1865). The Gibla region is supposed to have been located in the Trarza ${ }^{195}$ Emirate. Among Muhammad al-Mami's many works, is one called Kitab al-Badiya, which is translated either as 'Book of the Desert' or 'Book of Nomadism.' The phrase trab al-bidan is mentioned in this book and, according to a volume of collected works published by six public universities in Madrid, it:

Is [an] expression of a Mauritanian colleague, El Hassen ${ }^{196}$, translating the intentions of Shaykh Muhammad al-Mami as provisional space where compliance $^{197}$ with the 'urf ${ }^{198}$ is imposed, from local custom, made inevitable given that it is, in the words of another great Saharan sage, Sheikh Sidi Muhammad al-Kunti, ${ }^{199}$ a, I quote, 'country without master,' where there is neither king nor prince, nor pious leader capable of placing the habitants from shelter of injustice and arbitrariness" ${ }^{, 200}$ (Martínez Lillo et al. 2009, 216).

\footnotetext{
195 See Map 5.1.

${ }^{196}$ El-Hassen, as a person of historical significance, remains un-sourced and unidentifiable.

${ }^{197}$ Other translations may read "where reverence to the" or "where respect of the" urf is imposed or implemented.

${ }^{198}$ Urf is customary law in Islam, which consists of traditional customs and practices on the local level that are not directly based on the Quran and hadith but that still have legal weight. Before the modern era, it was largely unwritten and not codified. Campo, Juan E., Encyclopedia of World Religions: Encyclopedia of Islam. New York, NY, USA: Facts On $2009 . \quad$ File, 2 ProQuest
} http://site.ebrary.com.ezproxy.fiu.edu/lib/FIU/reader.action?docID=10315266. Accessed 10 June 2015.

${ }^{199}$ Shaykh Sidi Muhammad al-Kunti (1769-1826) was a Saharan scholar who between the approximate years of 1811 and 1826 had taken over "as head of the zawiya [religious order of] Qadiriyya that his father had created in the Malian Azawad, around the wells of al-Mabruk and Bujbayba, some 300 kilometers northeast of Timbuktu." Abdel Wedoud Ould Cheikh states that al-Kunti left a considerable amount of writings that remain unpublished. "A Man of Letters in Timbuktu: al-Shaykh Sidi Muhammad al-Kunti," Chapter 15, in The Meanings of Timbuktu, eds., Shamil Jeppie and Souleymane Bachir Diagne, Human Sciences Research Council, 2008) 238, 231, accessed January 15, 2016, http://codesria.org/spip.php?article643.

200 Taken from the Spanish, "expresión es de un colega mauritano, El Hassen, que traducía las intenciones de Chej Muhammad al-Mami como espacio de la provisionalidad donde se impone el acatamiento de "urf, de la costumbre local, dado que se trata, en las palabras de otra gran sabio sahariano, Chej Sidi Muhammad al-Kunti, de un, cito textualmente, 'país sin señor', donde no hay rey, ni príncipe, ni jefe piadoso capaz de poner a los habitantes al abrigo de la injusticia y de lo arbitrario." Pedro Martínez Lillo, Silvio Arias Careaga, Caros Tanarro Alonso, Julia Weingartner (Coords.), Oficina de Acción Solidaria y Cooperación / Universidad Autónoma de Madrid, Universidad y Sahara Occidental: Reflexiones para la Solución de un Conflicto, Cuadernos Solidarios No.6, Spain: R.B. Servicios Editoriales, 2009. 


\section{"Boundaries" as a Source of Identity}

The collection of works cited above is one of the few that mention these Saharan scholars because their discovery was only made public in 1975 when it was presented as evidence to the ICJ (Western Sahara Oral Statements [ICJ] 1982, 135 and 286). The group that compiled the aforementioned study stated that the discovery of the work of al-Mami has created opportunities for debate about the political and juridical fundamentals of Saharan society. It has uncovered that the nature of Saharan society was distinct from one in the north ruled by the Sultan. The following describes al-Mami's writings in the mid-nineteenth century and what it may infer about the development of a separate Saharan society; a precursor to a possible Sahrawi collectivity. It also will comment on the labels given to physical boundaries that today are utilized as arguments for separateness by the Sahrawi.

The collection enumerates several points in al-Mami’s writings, which 1) “make visible a representation that Saharan society was built on its own, breaking..." the European discursive monopoly; 2) allows one to better reflect on the conditions of Saharan identity; and, 3) "is a modest homage to the complexity of a social order" that has just begun to gain interest in Spain (Martínez Lillo 2009, 216). In another work, only recently published, [al]-Mami “distinguished himself for his geographic texts on the land, regional songs in which he declared the secular independence of his country"201 (Mahmud Awa 2015, 4). Mahmud Awa mentions that al-Mami "proposed formulas of government that organized and agglutinated the inhabitants of the territory, then grouped in different tribes, in a single state"202 (ibid.). Criado furthers the argument by affirming this 'independence' and asserting that the Kitab al-Badiya "talks about the

\footnotetext{
201 Translated from the Spanish by the author: "se destacó por sus textos geográficos sobre la tierra, cantos regionales en los que declaraba la independencia secular de su país." Bahía Mahmud Awa, "Generaciones Literarias: Intelectualidad y Política en el Sahara Occidental, 1850-1975," Les Cahiers d'EMAM (Études sur le Monde Arabe et la Méditerrané) [Online] 2015, 24-25, Sahara Occidental: Mémoires, Culture, Histoires-Culture et Politique Series, accessed June 18 2015, http://emam.revues.org/774.

202 Translated from the Spanish by the author: "propuso fórmulas de gobierno que organizara y aglutinaran a los habitantes del territorio, entonces agrupados en diferentes tribus, en un solo estado." Ibid.
} 
life and culture of nomads and distinguishes other neighboring countries among which it cites Chinguetti (currently Mauritania), Timbuktu (Mali), and Tichit (southern Morocco)"203 (1977, 83). Moya Fernández even affirms for al-Mami that:

"[F]or him the peculiar geographical and historical conditions of the Sahara, out of the way from the central powers of Islam and being a predominantly nomadic society was conditioned to self-regulate in a particular manner; having overcome the existence of a central authority, the Sahara was defined as a land 'without king or prince or ruler' ",204 $(2009,86)$.

PHYSICAL BOUNDARIES: The fact that the ICJ accepted this newly discovered evidence is surprising and perhaps even dangerous without sufficient scholarly review. The importance of these expressions sourced from these Saharan scholars needs much more study. Nevertheless, Muhammad al-Mami, as a historical person, did exist and left many works. However, the copies of such works are scattered and found in few locations. To date, they are available only in Arabic (with hardly any copies translated into another language) and, most worrisome of all, have scarcely been studied. Yet, a few authors cite al-Mami and also refer to his mention of a distinct boundary called 'Jat al-Jaof,' which delineated most of what is the trab al-bidan. Jat al-Jaof has been translated as "línea de peligro o barrera del peligro" (Spanish for line of danger or barrier of danger) (Criado 1977, 78; Moya Fernández 2009, 12). This boundary was actually presented to the ICJ as verifiable proof by a Spanish representative in arguments against the Moroccan claim over the Western Sahara. In it Mr. Martinez Caro (on behalf of the Spanish Government) stated that:

The nomads' land, such defined in contrast to that of sedentary populations, substantially coincides to the north with the historical borders of Morocco and to

\footnotetext{
203 "habla de la vida y de la cultura de los nómadas y distingue otros países vecinos entre los que cita Chingueti (actual [Mauritania]), Tomboctú (Mali), y Tichit (sur de Marruecos)." Ramón Criado, Sahara: Pasión y Muerte de un Sueño Colonial, Chatillon-sous-Bagneux: Imprimerie S.E.G., 1977.

${ }^{204}$ Translated from the Spanish by the author: "[P]ara él las condiciones geográficas e históricas peculiares del Sahara, alejado de los poderes centrales del Islam y siendo una sociedad mayoritariamente nómadas condicionaban a que se autorregulara de forma particular; superada la existencia de una autoridad central, el Sahara se definía como tierra 'sin rey ni príncipe ni señor'." Conchi Moya Fernández, Delicias Saharauis, (No Place: Bubok Publishing, 2009 ), 86.
} 
the south with the Emirate of Adrar Tmar. To the west, it reaches the Atlantic Ocean, and to the east it would be more or less defined by that in the oral and written traditions of Western Sahara, called Jat al-Jaof or 'danger line' - a kind of border, facing the exterior, of all the nomadic tribes that used to inhabit the territory ...The Jat al-Jaof was thus a geographical as well as a political frontier, because it would sometimes separate zones that were litigious or belonging to tribes that were not a part of the agreement ${ }^{205}$ (ICJ 1982, 135-136).

Despite the lack of peer-review study because of its inaccessibility, a few media sources did report on the 'frontier' findings. For example, when the ICJ disclosed its concluding "Western Sahara: Oral Statements and Correspondence," a few newspapers such as the Sahrawi bilingual La Realidad ${ }^{206}$ (June 21 1975) and ABC, a Spanish Daily newspaper, reported that "a document about the frontier between the Sahara and Mauritania" had been deciphered and presented at The Hague to the ICJ (July 21975,9$)$. Thereafter, a few authors such as Criado $(1977,83)$ and the Dirección General de Promoción de Sahara $(1975,24)$ have mentioned this geographic boundary. Today, it has become legitimized and taken to be somewhat official proof that there was an "independent" zone away from the rule of the Moroccan sultans because the evidence was allowed at the ICJ. Sahrawi blogs and pro-Western Sahara websites have already appropriated these "proofs" and used these boundaries to solidify their claims as a distinct identity, that live separately (geographically and conceptually) from Moroccans. Modern scholars such as Mahmud Awa (2015), Moya Fernández (2009, 87), and del Riquelme (1991, 117-118) have begun to refer to this geographic division.

\footnotetext{
${ }^{205}$ Translated from the French by María Antonieta García what is in italics: "La terre des nomades, ainsi définie, par rapport à celle des sédentaires, coïncide sensiblement au nord avec les frontières historiques du Maroc et au sud avec l'émirat de l'Adrar Tmar. A l'ouest, elle arrive jusqu'à l'océan Atlantique, et à l'est elle [sic] se trouverait plus ou moins définie par ce que, dans les traditions orales et écrites du Sahara Occidental, on appelle le Jat al-Jaof ou "ligne de danger" - sorte de frontière commune, face à l'extérieur, de toutes les tribus nomades qui habitaient le territoire. Cette ligne partait, selon la tradition, des environs du cap Blanc, continuait au sud-est, en territoire aujourd'hui mauritanien, passait un peu au nord d'Atar, de Chinguiti et de Ouadane, remontait vers le nord, traversant les puits de Turin, un peu a l'est de l'actuelle frontière du Sahara occidental jusqu'à la sebka de Tindouf et revenait vers l'océan en suivant le basin du Draa...Le Jat al-Jaof était ainsi une frontière aussi bien géographique que politique, car elle séparait parfois des zones litigieuses ou qui appartenaient à des tribus qui ne faisaient pas partie de l'entente." "Western Sahara, Volume V, Oral Statements and Correspondence," International Court of Justice Pleadings, Oral Arguments, Documents, 1982.
}

${ }^{206}$ Now a long-since defunct newspaper because of the political sensitivities from the Western Saharan conflict. 
LITERARY BOUNDARIES: The 'first golden age' of Saharan scholarship, ${ }^{207}$ which included alMami's works, arose in the eighteenth century and lasted until the early nineteenth century (Dirección General de Promoción de Sahara 1975, 13). These investigators and a few other scholars speak of this golden age developing in the Tiris region of the Sahara. Today, the Tiris (a mostly desert plain of the northwest Sahara; refer to map 5.5 below) region is divided among three areas: 1) the Tiris al-Gharbiyya or Western Tiris in Western Sahara proper; 2) a small sliver of the Western Tiris that is now part of what is named by the POLISARIO as the 'liberated' or 'free' zone of the Western Sahara; and 3) the Mauritanian province of Tiris Zemmour. These Saharan works of poets, historians, and theologians flourished at a time when Europeans began to re-establish more commercial and political exchanges, because of more active exploration in west and northwest Africa. Muhammad al-Mami wrote a book titled Kitab al-Badia (Book of the Nomad). It is an account of the nomadic independence of tribes within the trab al-bidan demarcated by the Jat al-Jaof. A few pro-Sahrawi scholars to point to al-Mami's Kitab as proof that the 'nomadic independence' of tribes is a key distinction to their identity.

The problem with these claims by those who have actually viewed the Kitab al-Badia is the issue of hermeneutics. For example, Mauritania had presented al-Mami's work in order to augment their claim to parts of the Western Sahara. Spain had submitted oral arguments to the contrary, interpreting the Kitab's descriptions as tribes independent from any authority. Morocco maintained: "that to better interpret the original agreement we must talk about 'domain' and not of 'sovereignty,' which has led advocates of the Moroccan thesis to maintain that the Sultan always had sovereignty over the Saharan lands that Spain would later occupy, although not necessarily

\footnotetext{
${ }^{207}$ The 'golden age' of Saharan scholarship is referred to the works of Al-Mami and al-Kunti in the eighteenth century in the fields of history, literature, poetry, and science.
} 


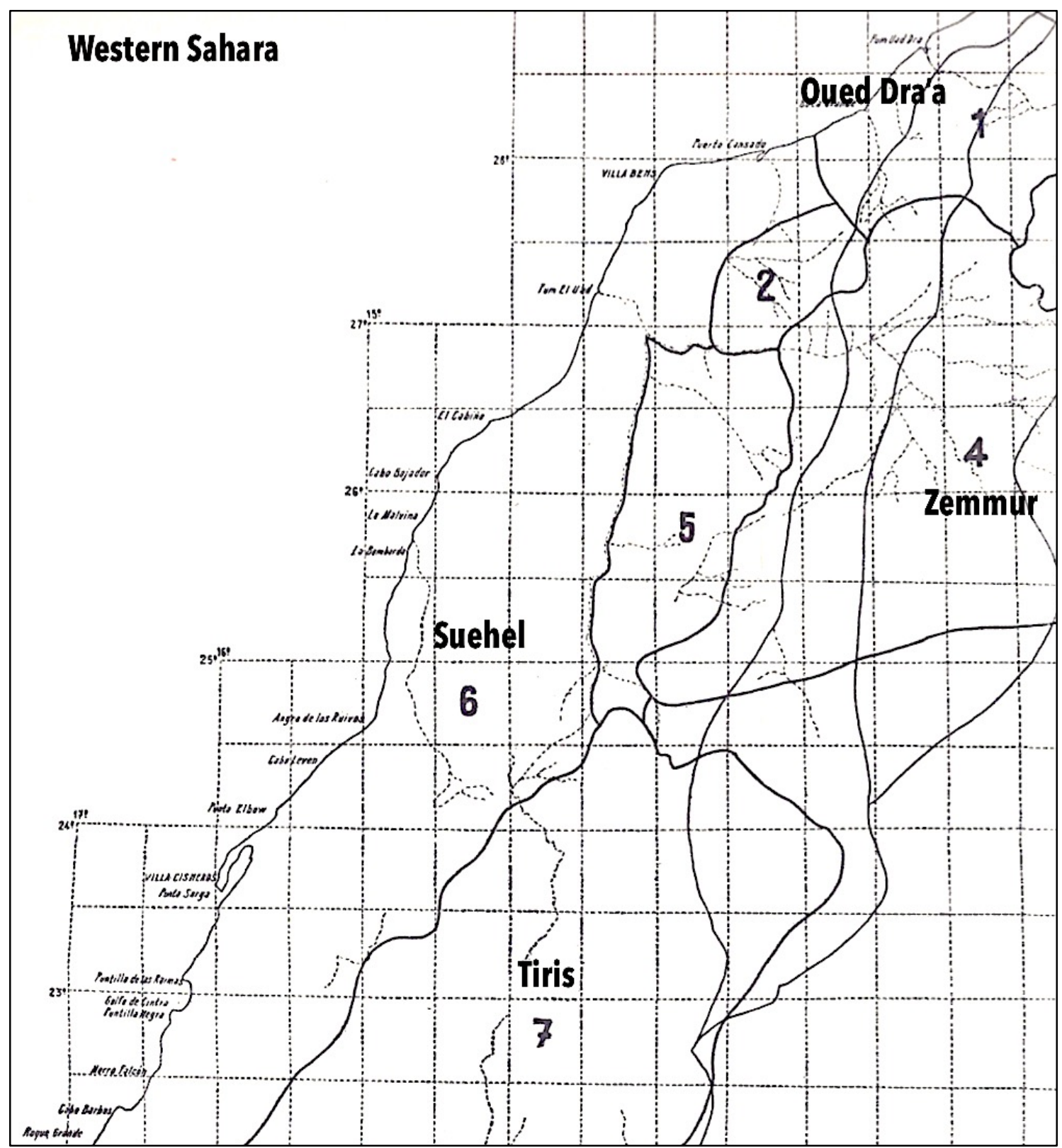

Map 5.5: Principal Regions of the Western Sahara ${ }^{208}$

its domain"209 (Algueró Cuervo 2006, 45). Thus, despite Muhammad al-Mami’s 'Tirisian’ account, Morocco will insist that the Sultan still had 'dominion' over these territories.

${ }^{208}$ Map adapted from Caro Baroja, Estudios Saharianos (Madrid: Calamar Ediciónes, 2008), 68-69. 
The question then becomes defining what is dominion? How did the Alawite Kingdom announce the extent of its power to its external 'desert provinces'? Were there tribal agreements made with the Sultan as to the recognition of his authority in the trab al-bidan? Perhaps there were inter-tribal accords made to acknowledge the Sultan on his behalf? How did Morocco exactly delimit their domains? Did they use geographical landmarks for physical boundaries? How does one go about placing landmarks in a desert? These questions are difficult to answer because more study is needed to evaluate these 'desert chronicles.' The issue over territorial control is a much older problem than depicted here in this chapter and adds to the historical claim of separateness from Morocco. Even though historical territorial control may not be central to Sahrawi distinctiveness, it is an important part of their identity.'

\section{Saharan History as Identity: Tribal Independence}

Difficulties arise in the search for historical accounts about the Sahrawi at the latter end of the eighteenth century. The literature, excepting a few a works, centers on Moroccan descriptions of history. Scholars on both sides of the conflict usually cite the treaties Marrakesh (1767) and Meknes (1799) and the problems therein, but then 'jump' to 1830 or beyond. My research has been able to uncover some forms of historical data in French and Spanish, but because of the limited knowledge of Arabic many works within this period—-the first golden age of Saharan scholarship - are unavailable. Despite these obstacles, the following sketch is an attempt to find links to a Sahrawi 'past.' This section reveals that south of the Moroccan sphere of influence there was an area of Saharan society that developed independently. It details how tribes already independent, rebelled, ignored, or passively recognized the Sultan. It also demonstrates

\footnotetext{
209 Translated from the Spanish by the author: "que para bien interpretar el original del acuerdo hay que hablar de 'dominio' y no de 'soberanía,' lo que ha dado pie a los defensores de la tesis marroquíes a mantener que el sultán siempre tuvo la soberanía sobre las tierras saharianas que luego ocuparía España, aunque no necesariamente el dominio." Algueró Cuervo, El Sahara y España: Claves de una Descolonización Pendiente (Las Palmas de Gran Canaria: Ediciones IDEA, 2006), 45.
} 
how tribes of the greater Western Sahara ran their own affairs, traded, and warred with each other without consulting the Sultan of Morocco. The following recounts an independent historical tradition that the Sahrawi claim as separate to Moroccan history in the late eighteenth and early nineteenth centuries.

Morocco had claimed, even before this period of history, lands to the greater southern areas of the Sahara and the littoral coast of the Western Sahara. Yet, at several historical junctures, including this one, Morocco had trouble keeping itself together as a political entity. Unrest had begun because many of Sidi Muhammad's black armies were forced in 1775-1776 to divide, were sent to different parts of the Moroccan region. They became dissatisfied, and rebelled against the Sultan. It is important to note that the power of the Sultan depended largely on his armies to carry out conquests, implement order, and exert influence. The 'abid contingents had once been a monolithic group that exhibited loyalty only to the Sultan. However, the new, more urban army had developed a strong sense of entitlement and had become split among rival political leaders. These local rivals had, for some time, begun to integrate Arab and Berber recruits into their local militias. The 'abid armies grew resentful of these changes. Subsequent revolts by these black armies and local insurrections kept most of 'Morocco' under subtle turmoil.

Certain regions and tribes highlight the pattern of the lost Saharan history beginning in the latter half of the eighteenth century through about the 1850 s. Much of what today is considered Western Sahara proper was devoid of direct control between the 1750s and 1820s. Despite some tribes recognizing the Sultan's spiritual authority, many Saharan qabila (confederations of tribes) actively governed their own affairs and pursued their own interests-in grazing and trade. Sidi Muhammad's death gave the seat of 'Morocco' to his son al-Yazid. Two years of relative unruliness marked al-Yazid's short reign. Yet, well before the beginning of the nineteenth century, the Western Sahara had developed its own historical record of events 
independent of the makhzen government of the 'Moroccan Empire.' Damis argues that in these “areas of dissidence, tribes would accept the Sultan's suzerainty but refused to submit to central administrative control" $(1983,20)$. One of these regions lies between the Oued Nun, including the Oued Dra'a, and north to the Sous River Valleys. In summary, Damis states that: "During the periods of central weakness or instability, tribes near the periphery would rise up in revolt, enlarging the siba lands and encroaching on the area under the sultan's control. At the same time, there were tribes that submitted partly to central control, thus forming areas of semi dissidence. A tribe in the middle ground might receive the sultan's officials and obey their directives but refuse to pay taxes" (ibid).

Trout recounts that, "around 1765, most of the Tekna confederation found near the mouth of the Oued Draa broke away from Moroccan control" $(1969,143)$. The Tekna were described above as a tribal confederation but Lydon writes, "many [of his] informants explained that the Tikna [sic] formed a national entity (emphasis added) rather than a 'tribal' or even ethnic one" $(2009,174)$. They had briefly developed an autonomous principality in the city of Tazeroualt, whose main port was Masa, until Moulay Rashid took control of the city (Pazzanita 2006, 40607). Much later and relevant to this period, a branch of the Tekna, the Ait Moussa ou Ali arose to create another smaller independent Oued Nun princedom, "centered upon the trading town of Goulimine" (or Guelmim ${ }^{210}$ ) (Trout 1969, 143). Other sources state that Tazeroualt resurfaced again "constituting a virtually independent maraboutic ${ }^{211}$ principality until the late 19th century" (ibid.; Schroeter, 2015). In fact, Trout broadens the geographical scope of Moroccan non-rule by writing: "Farther to the east, along the upper course of the oued Dra [sic], from the High Atlas to

\footnotetext{
${ }^{210}$ Another alternative spelling includes Guelmin.

${ }^{211}$ Maraboutic from the root marabout is the designation of a saint or his descendants who are called upon to dispense blessings, and whose tombs are places of pilgrimage. In this context, a maraboutic city-state seems to be one where its inhabitants are either descendants or followers of a Muslim saint buried in that area.
} 
the 'Bend of the Dra' (where all sedentary population along the Dra ends), Moroccan authority was sporadically maintained; but even here open revolt was a frequent occurrence" $(1969,143)$.

López Bargados relates how another confederation of tribes or qabila, ${ }^{212}$ the Oulad Delim, which under Saharan tradition were thought to be part of the Beni Hassan, became very independent of Moroccan control as well after the Shar Bouba War in the mid-seventeenth century. He claims that they are of particular importance because of their regional singularity and close ethnic affinity to the Arab Hassani tribes. They gravitated to the Western Sahara's bidanic region between the thirteenth and fifteenth century. Gradually, they moved south into the nomadic territory of the Tekna and finally to the peripheral domains of the Trarza Emirate, coming into conflict with both independencies. There is no mention of intervention by the Sultan $^{213}$ in any of these battles that lasted for decades with the eventual defeat of the Oulad Delim. However, El Hamel writes that in 1807, the Sultan did lead an expedition to Guelmim, an important link in the caravan route. Nevertheless, El Hamel also writes that the ruler of the people of Guelmim, 'Abd Allah Usalim "commanded independently [emphasis added] a vast region in the western Sahara...dominated the trans-Saharan caravan trade and had an army of fifteen hundred black slaves" (El Hamel 2013, 233).

Despite the propensity toward disparate tribal affiliation, contempt for the Sultan's authority, and the susceptibility of each to warring, there was a semblance of order within and among tribes (or tribal confederations). Criado finds that there is not only evidence of a suspension of warrior-like activities but also proof of collective responsibility among tribes. Criado, commenting on López Bargados' mention of a tribe called the "Bu Amaran" (although his writing focuses mainly on the Oulad Delim) located in the Oued Nun next to Ifni, discusses how they had "dedicated themselves to agriculture from October to May and that, once the

\footnotetext{
${ }^{212}$ Some refer to this term as a large confederation of over a dozen clans. Lydon, On Trans-Saharan Trails, $2009,42$.

${ }^{213}$ Except to provide aid to the Trarza Emir Ali Sandura decades earlier.
} 
harvest was obtained, they rushed to war amongst each other until the new sowing season"214 (1977, 87; López Bargados 1955, 341-342). He insists that these skirmishes, "typical of the Moroccan bled as-siba" did not exist among the tribes of what he describes as the Sario. ${ }^{215}$ (Criado 1977, 87). "They had established once and for all a supratribal order that avoided the waste of energy and human life and that it would allow the resolution of disputes through mediation" 216 (Ibid). Caro Baroja has implied that Western academic study of the tribe, especially in terms of the Western Sahara, is prone to view it as disparate, disorderly, and anarchic. While these characterizations may be true, they only apply when there is another power that attempts to co-opt, win, or conquer the region of its inhabiting tribes. Therefore, the alternative position would indicate, based on the evidence of 'super tribes' or, as some scholars have designated, confederations of tribes, that there was indeed 'tribal' order. Still, it was “"primitive,' egalitarian, and static, lacking in itself the necessary elements for an evolution" but one which does not conform to Western pretensions of social order (Criado 1977, 87).

Moulay Sliman came to power as Sultan of Morocco in 1792 and his reign lasted until 1822. He was able to take control of the north of Morocco and proceeded to suppress and bring under his control the 'unruly' south. Julien notes that Sliman managed to "enlarge... [the bilad almakhzen] somewhat by bringing back under control the Dra' [sic], Figuig, and part of the

\footnotetext{
214 Translated from the Spanish: "los Bu Amaran se dedicaba a la agricultura de octubre a mayo y que, una vez obtenida la cosecha, se lanzaban a guerrear entre ellos hasta la nueva época de siembra" in Criado, Sahara: Pasion y Muerte de un Sueño Colonial, 87.

${ }^{215}$ Sario is an abbreviation of the Saguia al-Hamra and Rio de Oro regions of the Western Sahara.

216 Translated from the Spanish: "que habían establecido de una vez para siempre un orden supratirbal que evitara la pérdida inútil de energías y vidas humanas y que permitiría resolver los litigios por vía de mediación” in Criado, 87.

217 Taken from the Spanish and translated by the author: "que carecía en sí misma de los elementos necesarios para una evolución." Criado, 87.
} 
$\operatorname{Tadla}^{218} "(1970,269)$. However, once again his power waned and by 1818 he had lost the Tadla. By his death the area "once more headed for anarchy" (ibid.). El Hamel documents that Moulay Sliman had trouble reorganizing his country due to the rebellious black armies, internal dissension among local power brokers in the different cities, and usurpers to his authority in the east and south of Morocco $(2013,226-227)$. Apart from Rézette (and his more pro-Moroccan view of the period), Dunn in Arabs and Berbers speaks of political investiture given by the Moroccan Sultan to local leaders. However, the references that Dunn makes seem to be about populations in Tafilalet and the city of Sijilmasa, and even farther to the southeast in Tuat (which is now in present-day Algeria) (Dunn 1972, 99). These are regions to the east of Morocco over the Atlas Mountains stretching into the Sahara Desert. Apart from some correspondence and a referenced gift sent to the Emir of Trarza there has not been any mention of an authoritative investiture given to the southwestern Emirates of the Sahara. While this was probably true for the east and some of the southeast areas of the Morocco, the south and southwest along the Atlantic coastline, beginning with the Sous Valley, has been, more often than not, described as the bilad al-siba (land of dissidence) and by extension part of the trab al-bidan.

Confederative tribal struggles of power over trading routes, grazing territory, and blood feuds marked much of the late eighteenth and early nineteenth centuries well into the $1850 \mathrm{~s}$. López Bargados writes of the wars between the Oulad Delim and the Oulad Qaylan tribes (2003, 248). Another confrontation was that of the Oulad Delim with the Reguibayt, including constant ghazzian (warrior) raids by the Oulad Delim defended by the leader of the Trarza Emirate Ahmad wald 'Ayda. These battles between the eastern section of the Oulad Delim, the Oulad Salim and Oulad Mulat, (ibid., 240; Caratini 1989, 79) was fought for twelve years (1824-1836). Timbuktu had finally been subjugated by the Tuareg in the 1790s. Caro Baroja notes that the Reguibayt began a struggle with the Tajakant in 1825 and ended with the complete victory by the latter

${ }^{218}$ The Tadla is located surrounding the city of Boujad on Map 5.2 and 5.4. As an interesting note, the author lived and taught English in the city of Boujad while he served as a U.S. Peace Corps Volunteer in 2002-2003. 
(1955, 348-349). Perhaps before 1830, another tribe, the Ait Atta, who would later merge into the Tafargant alliance with the Bani Mhammad, also escaped Sultanic control during the reign of Abd al-Rahman, Moulay Slimane's son, and secured their hold of the western Ziz Valley in the Tafilalet region in the eighteenth and nineteenth centuries (Dunn 1972, 91-93). This alliance of tribes was largely successful focusing on the commercial trading enterprise along the eastern fringes of the Ziz Oasis (ibid., 98). It also maintained such peaceful relations with another the Dawi Mani, for pasturage in the east of the Ziz that "inter-tribal boundary demarcations did not exist and conflicts over grazing rights were isolated and infrequent" (ibid., 92). These tribal struggles are written by these sources but they arrive in these volumes as part of oral history.

These accounts serve to highlight the nature of tribal independence and their objection to the Sultanate outside of the major 'Moroccan' cities of Fes, Marrakesh, its northern coastline, and east of the Atlas Mountains. These tribes were running their own affairs after the demise of Muhammad III in 1790. The actions of these tribes argue for the autonomous nature of their society. The POLISARIO assert that these examples of autonomy prove that the Sultan never had complete control over the Western Sahara. They will make the historical claim that 'Sahrawi' tribes were not only making independent choices but were also cohabitating separately from the Kingdom of Morocco, irrespective of any spiritual investiture. Damis admits that Morocco can argue that these tribes recognized spiritual authority but questions how "the sheer distance between the Sahara and the seats of power in Fes, Meknes, or Marrakesh posed an obvious obstacle" - and logistically, it would be almost impossible to 'exercise' administrative control over the nomadic tribes, which required "population centers...[and] the Western Sahara has no major oases or other natural centers from administrative control could be exercised" (Damis $1983,21)$. Autonomous tribal action and the habitation of populations not under control of the Sultan, however, do not constitute a unique identity. There were several tribes living in this 
manner. There was no collective awareness or 'national' identity much less one for a 'Sahrawi' identity.

\section{Early European Observations}

There are brief accounts among European explorers and diplomats in their travels and observations that document the tenuous rule of the Sultan. Here, only a few brief passages of their reflections will be given. These examples express the continuous problem of Moroccan territorial integrity. Europeans viewed the internal weakness of the Sultan as an opportunity for commerce with the tribes south of 'Morocco.' As they established trading posts and negotiated terms of commerce, they began to distinguishing between those tribes that were open to trade and those that were not; usually those that were controlled by the Sultan. These relationships would soon begin to help differentiate between subject tribes of the Sultan and those 'freer' tribes. At the same time, the sense of tribal autonomy allowed for disparate historical trajectories; one not subject to Moroccan control. Tribal identity, thus begins to change because of indirect influences.

One such comment by the representative of the Spanish Crown to the Court of Morocco, Jorge Juan, as official negotiator in the 1767 Treaty indicates the precarious position of the Empire. He states that:

It is true that the population of the whole country is neither as excessive as hitherto believed, which is evidenced in the small number of places, because although it is said that more live in encampments, nor are these as numerous, and proves that even in the province of Duquela that qualifies as the richest, and most populated, for just as we passed were they able to gather 10,000 men even though anyone who can handle a horse is presented with him, and those who could not [would present themselves] with weapons only, as if all were soldiers, when in fact they are nothing more than a kind of militia without discipline, or obedience, for such reasons any of its main squares [or parade grounds] that are reduced to [the cities of ] Tetouan, Tangiers, Larache, Sale, Mogodor [sic] and Santa Cruz could be taken by a surprise attack with 60 men who could land in the surrounding artillery area, which by the poor state of its fortifications have pointed them over the beaches, they would immediately lose capturing them from 
the rear without fear of any early relief, for at most could they seek in four days would be 6000 men [emphasis added] ${ }^{219}$ (Rodriguez Casado 1941, 41).

In another account written in 1813 , a notation is made concerning 'Modern Barbary' or what was historically described as the Barbary States, which included the empire of Morocco. ${ }^{220}$ Lempriere is referring to the southwestern extremities of 'Barbary' and their piratical activities when he states that: "To the west, the line of coast is not so extensive, as it does not reach further than Cape Non in the $29^{\text {th }}$ latitude, but it is sufficient to afford the Moors a ready access to several important islands in the Atlantic Ocean, and to extend their depredations to the western coast of Europe, which not unfrequently has suffered by their piracies [emphasis added]" $(1813,4)$. Later in his volume, Lempriere states that Tarudant, capital of what was previously the metropolis of the kingdom of the Sous, ${ }^{221}$ "may be considered as the frontier town of that part of the [Moroccan] emperor's dominions." He also states that:

The [Moroccan] emperor, it is true, claims the sovereignty of the desert of the Zahara [sic], and the territory of Vled [sic] de Non [sic]; but his authority over that part of the country is almost nominal as it entirely depends on the caprice and inclination of the Arabs who inhabit it; and who from their distant situation from the seat of government, are more properly under the dominion of their own chiefs. They acknowledge the emperor to be their sovereign, and the head of their church, and occasionally pay him tribute as sultan; but they give no attention whatever to his particular orders, and over their interior government he has not the least control. These people consist of different tribes of Arabs, who live in

\footnotetext{
${ }^{219}$ Translated from the Spanish by the author: "Bien es verdad que la población de todo el país no es tan excesiva como hasta aquí se ha creído, lo que se comprueba del corto número de lugares, pues aunque se diga que los más viven en aduares, tampoco éstos son tan numerosos, y lo acredita que aun en la provincia de Duquela que pasa por la más rica, y poblada, apenas cuando pasamos pudieron juntar 10,000 hombres siendo así que todo el que puede manejar un caballo se presenta con él, y con solas armas el que no lo tiene, como si todos fuesen tropa, cuando en realidad no son más que una especie de milicia sin disciplina, ni obediencia, por cuyas razones cualquiera de sus plazas de armas que se reducen a Tetuán, Tánger, Larache, Sale, Mogodor y Santa Cruz podría tomarse de un golpe de mano con 60 hombres que pudieran desembarcar en las inmediaciones de las baterías, que por el mal estado de sus fortalezas han tenido precisión de formar sobre las playas, que perderían inmediatamente tomándolas por espalda sin temor de algún pronto socorro, pues el mayor que en cuatro días podría acudir sería lo más 6000 hombres" in Vicente Rodríguez Casado, Jorge Juan en la Corte de Marruecos, Biblioteca de Camarote de la Revista General de Marina Series 4, (Madrid: Escelicer) 1941.
}

\footnotetext{
${ }^{220}$ William Lampriere lists those 'States of Barbary' as divided among "five distinct and independent sovereignties, viz. the empire of Morocco, and the kingdoms of Tremecen, Algiers, Tunis, and Tripoli" in A Tour through the Dominions of the Emperor of Morocco, London: Tayler and Co. (1813), 34.

${ }^{221}$ For in the same document, Lampriere does acknowledge that although the Kingdom of the Sous was an independent entity, it is now controlled by the Sultan of Morocco. Lampriere, Dominions of the Emperor of Morocco, 151.
} 
tents without any fixed places of residence: they wander over the country in search of plunder, and are supposed, on some occasions, to extend their depredations as far as Nigritia, whence they carry off Negroes" (Lampriere 1813, 152).

By the end of Abd al-Rahman ibn Hisham's reign (1822-1859), the Kingdom was beset by both internal conflict, which he managed to control, and direct French intervention. The French had taken Algiers in 1830 but did not completely vanquish Algerian resistance until 1847. Algerian resistance had received aid from tribes in Morocco during the 1840s to support the Emir 'Abd alQadir and his troops against the French. Irritated by Moroccan assistance, France then bombed its ports at Mogador and Tangier in $1844 .{ }^{222}$ The Spanish seized the Chafarinas Islands in 1849 off the northern coast of Morocco. The British pressured Morocco into signing a bi-lateral commercial treaty in $1856 .{ }^{223}$ Upon the death of Sultan 'Abd al-Rahman (1859) the Spanish observing the weakness of the Sultan, and not to be outdone by the major competing powers, declared their first official war (1860) with the Kingdom of Morocco in the North and secured "from Morocco the town of Ifni, near Cape Nun" in the south (Johnston 1966, 120). The engagements with the Europeans distracted the Sultan from its southwestern and southern Saharan periphery and left those territories unmanageable. In addition, due to the many-sided conflicts with the Spanish, French, as well as diplomatic exchanges with the British and even American frigates (because of piracy), Morocco almost fragmented into smaller political units. Thus by 1859 , direct European involvement began to influence Maghrebi politics, and its consequences would reverberate in the Western Sahara. Moroccan politics would forge a defense

\footnotetext{
${ }^{222}$ Today it is known as the Franco-Moroccan War of 1844. The Emir 'Abd al-Qadir finally surrendered to the French in 1847. John E Flint, The Cambridge History of Africa from c. 1790 to c. 1870, Vol. 5, New York: Cambridge University Press, 1976, 112.

223 The General Treaty and Convention of Commerce and Navigation, signed in 1856, effectively gave Britain 'most favored nation' status in Morocco. Dr. Michael Willis, "Deepening Relations during the $18^{\text {th }}$ and the $19^{\text {th }}$ Centuries," Morocco and Britain. www.mbs.ma, Moroccan British Society, accessed July 15, 2015. http://www.mbs.ma/En/moroccobrit1-1.htm.
} 
of its frontiers against European encroachments and extol the aid of the surrounding tribal confederations.

This section attempts to link historical territorial autonomy as part of Sahrawi identity. It features autonomous tribes who manage their own affairs without approval from the Sultan or rebel against his in the Western Sahara. It also evaluates treaties that were agreed upon between Europeans and the Sultans. The Sultan(s) acknowledge that they did not have complete control of its southern flank. The discussion of physical boundaries based on the concepts of distinction highlight how the socio-political environment of the greater Western Sahara was viewed; there were groups that were different from those under the rule of a Moroccan sovereign. The section on literary boundaries presented the case that there were two competing historical trajectories: one being written by the Moroccan Sultans and another that has been neglected but 'rediscovered,' written by obscure Saharan scholars. Yet-to-be translated and studied manuscripts from these golden years of literature also seem to suggest that there was a Saharan-wide scholarship, providing evidence of an autonomous Saharan society. It depicts a whole separate history, independent of Morocco. It chronicles a distinct history of not only the Western Sahara but also the deep southern extremities of the region.

Historical evidence suggests that there was no break in the genealogical line of the Sultans. However, while it is difficult to criticize that Morocco was always a coherent religiopolitical entity, its socio-geographical (especially its southeastern, southern, and southwestern) frontiers certainly are open to question based on the research herein. The discussion in this historical period suggests that there were other tribal identities, separate from Morocco. There were other histories being written, boundaries were made, and were being recognized by both the Sultans and the Europeans. Still, instead of a fusion of independent clans moving toward one supreme, region-wide trans-Saharan federation of tribes, the opposite had occurred. Several 
independencies arose, power struggles ensued; different tribes had already merged with each other and established confederations of super-tribes. They competed with each other over land (grazing rights and agricultural resources), trade routes, and commodities - animal husbandry, gum, salt, gold, and slaves. Yet, the only possible association to the modern Sahrawi are the building of subtle 'layers of distinction': the Hassaniya language, separate tribal history, and territorial autonomy. These features of identity though were found among numerous tribes. Thus, despite these insights into Saharan society, a less than cohesive Moroccan Empire, and proof of self-governing super-tribes, there are no concrete links to Sahrawi national identity in this historical segment. 


\section{IDENTITY CONSTRUCTION IN THE MIDST OF EUROPEAN INTERVENTION}

$(1860-1883)$

This chapter will focus on the roots of Sahrawi identity from the period beginning in 1860 until right before the Act of Berlin in 1884. This period includes the diplomatic peak between Morocco and Spain over commerce and territory surrounding the contested frontiers of Morocco. The Berlin West Africa Conference, a series of negotiations (Nov. 15, 1884-Feb. 26, 1885) held in Berlin where the major European powers "met to decide all questions connected with the Congo River basin in Central Africa" effectively accelerated European "spheres of influence,' which included northwest Africa (Britannica, 15 ${ }^{\text {th }}$ ed., s.v. "Berlin West Africa Conference"). Although these dates are not exclusive to the Sahrawi timeline, they do represent historical landmarks in the search for the roots of their national identity. The socio-historical analysis of the period in the western and southwestern Maghreb region (including Mauritania, Western Sahara proper, and Morocco) continues to provide insight to claims of separateness. The continuing question remains: do the origins of Sahrawi identity lie within this period, and in what form does it materialize?

This chapter will analyze historical sources that document Western Saharan history, including maps from the latter nineteenth and early twentieth centuries depicting frontiers of the northwestern Sahara and literature about the Western Sahara. Written texts begin to expand with respect to this period, but only provide intermittent details of 'Sahrawi' history. The literature is scant and considerable effort has been made to find as much information as possible with the limitations discussed in the introduction. The research found alternative sources of information not available in the United States - via independent booksellers in small street bookshops and online booksellers, at the various AHN (National Historical Archives) localities, and in the BNE (Biblioteca Nacional de España) in Madrid. It is the hope that this chapter will shed some light as to the approximate origins of Sahrawi national identity. 
This period does not lend itself to the primordial theory of Sahrawi origins in the near past. Again, questions arise about what can be considered as the traditional past. Is 1860 too early to be considered as evidence for a primordial past? Perhaps highpoints in the discernable past, despite fluctuations in national awareness, are links to national identity. The argument linking national identity to historical features falls within the theoretical approach of primordialismperennialism. From perennialism, an argument can be derived demonstrating that despite evidence contradicting the notion of any formal acknowledgment of nationhood, there might be 'low levels' or traces of sentiments of national coherence. Undoubtedly, further questions arise about how these low levels of identity should resemble—-how are they to be discovered, or what should one search for? Clearly, 'perennial' notions of history must demonstrate traces of an identity that can be associated to later, more distinct manifestations of nationality. These lowlevel forms of national identity are far beyond the scope of this work. That work will be left to anthropologists and other social scientists. Here, the reader should consider the socio-historical evidence presented and judge for themselves.

By 1860, the Western Sahara entered the modern period of world history. Previous chapters presented a connection to the early modern (1524) to the beginning of the modern period of history (1789). ${ }^{224}$ This chapter seeks evidence that may indicate that the national identity of the Sahrawi was established within this period of history. It also seeks evidence that there are lingering traces of Sahrawi nationality that can be linked to previous eras. If the sources of Sahrawi national awareness were not evident in previous segments of history, then they must have begun at the dawn of European intervention, if not later in this period. This argument is widely considered, by most modern scholars of the Western Sahara, to be the most prominent for the development of the Sahrawi national identity.

\footnotetext{
${ }^{224}$ Chapter five was written about the sources of identity from 1758 to roughly 1859 , which includes what scholars of history claim as nearing the end of the 'early modern' period of 1800, using the French Revolution of 1789 as a benchmark. By 1859, nations have entered the modern period of history.
} 
A combination of both the primordial and top-down level arguments is based on the region's socio-political environment. The second hypothesis claims it is arbitrary and subjective to select point of origin - indeed almost instrumental, especially if a group is making a case for its cause. Thus, its arguments, formulated from constructivism, advocate that: 1) Sahrawi identity was created in response to the encroachment of foreign powers into west and northwestern Africa; 2) in this period of history, Western Saharan society became more organized as a sociopolitical entity due to stronger regional ties, not only to other groups, but also to the land. These two derived explanations further pursue a diverse understanding of nationalities - from the ground level and upper levels of influence. The constructivist approach resonates most fully with contemporary social science thinking, in that it enhances our understanding of identity politics by fusing instrumentalism and primordialism - two streams of thought that some suggest are largely dated and unpopular.

Yet another argument derives from pure instrumentalism. The argument posits that group cohesiveness may be a result of regional leaders (shaykhs, sultans) or other actors (foreign powers or leaders)—sometimes labeled as "ethnic entrepreneurs"—co-opting, manipulating, or embellishing directly, subtly, or unwittingly the markers of identity for solely economic or political objectives. The only force powerful enough to forge a sense of national consciousness among the Saharan population in the previous chapters was that of the Sultan of Morocco. However, his influence was stunted in the face of prominent forces such as the southern Emirates in the Western Sahara and other tribes who chose not to acknowledge his authority. The intrusion of the French and Spanish in the internal affairs of the Western Saharans may be the biggest marker of identity formation for the Sahrawi but not before they had already established nominal political independence prior to 1860 . Still, the historical analysis must continue to ask if, in fact, there were select proto-Sahrawi leaders who could bring together these populations. tribes. Constructivists seek products of human social interaction, that is, socialization and historical 
forces states that combine a combination of cultural artifacts and social constructs. This section, then, evaluates how Europeans, the Sultanate of Morocco along with the tribes of the

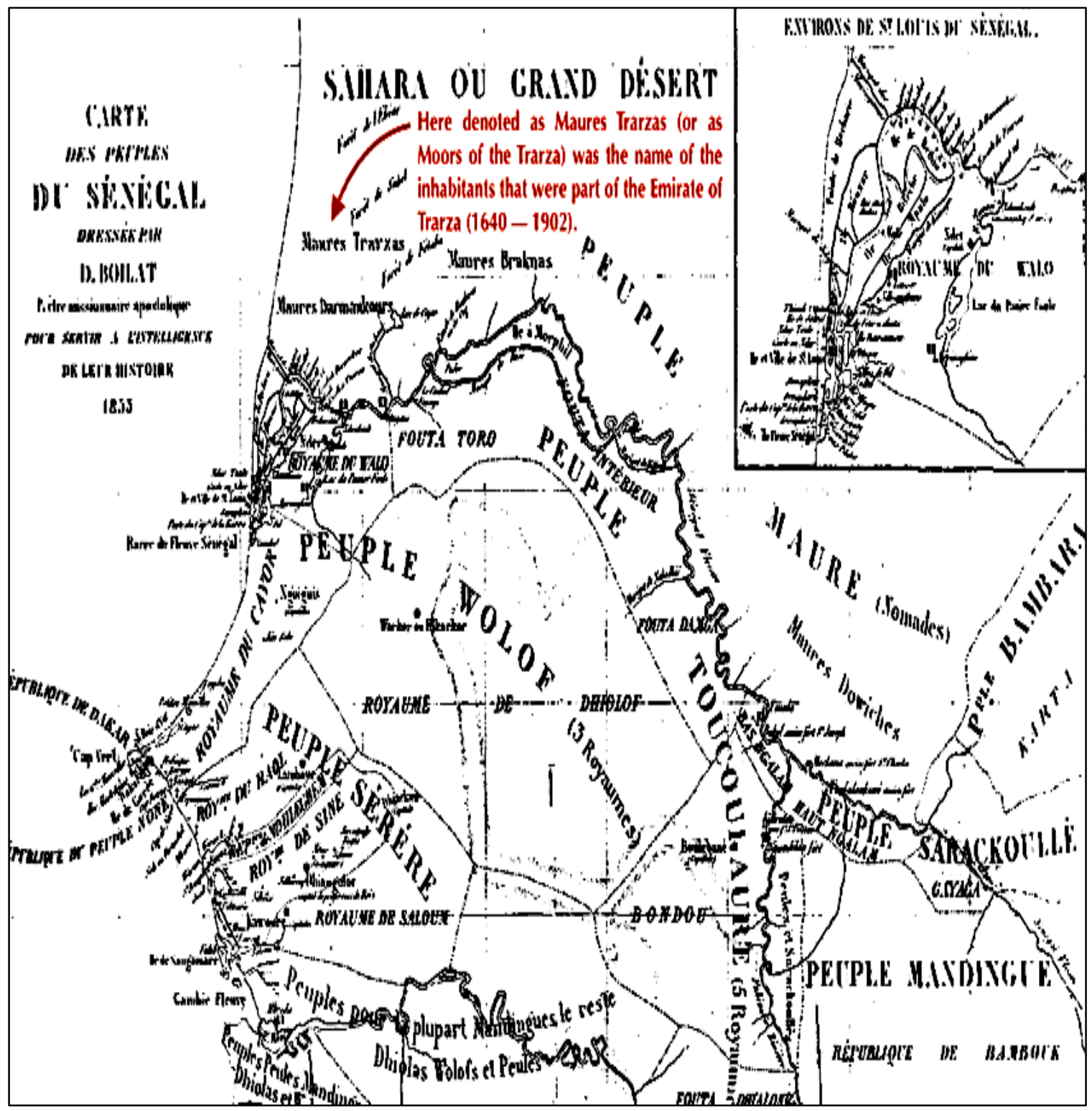

Map 6.1: Map of the People of the Sénégal ${ }^{225}$

\footnotetext{
${ }^{225}$ Map taken from Abbé David Boilat, "Carte des Peuples Du Sénégal," in Esquisses Sénégalaises: Physionomie du Pays-Peuplades-Commerce-Religions Passé et Avenir Récits et Légendes (Paris: Librairie P. Bertrand, 1853), 512, Gallica.bnf.fr. - Bibliothèque Nationale de France, accessed June $12 \quad 2015$, http://gallica.bnf.fr/ark:/12148/bpt6k103361c/f512.image.
} 
greater Western Sahara (see map 6.1 and the political communities in the deep southwestern Sahara) interacted with each other. Did these interactions aid in developing concrete forms of national identity among the Western Saharans? It seeks the synthesis of distinctive (Hassaniya, territorial affinity, political autonomy) ethnic features with the aspirations of actors or forces (resistance) as catalysts to Sahrawi identity. If the fusion of these top-down elements is evident in this period, then it will confirm the constructivist hypothesis for the origins of Sahrawi identity. If not, the search will continue.

The Socio-Political Environment of Southern 'Morocco' (1850s-1900)

Indeed, when Moulay Muhammad ibn 'Abd al-Rahman (or Abderrahmane), also known as Sultan Muhammad IV (1830-1873), replaced his uncle, Moulay Sliman, on the throne, Morocco's weakness was prominently displayed to the European powers. Julien in a very telling comment, wrote that: "Thus it was that, in a world in full and swift evolution and increasing daily in strength through improvements in means of transport and growth of the volume of trade, Morocco remained an amalgam of tribes, very unstably bound by the link of religion....and attached to a centuries-old if not thousand-years-old economic system" (Julien 1970, 270). Flint adds that European involvement in the Morocco-Saharan sphere of north Africa, which coincided in an untimely way for Morocco with the Sultan Abderrahmane's death, was "invariably the occasion for revolt in various parts of the kingdom" (Flint 1976, 122). Revolts broke out in Morocco in the north and in the south as the new Sultan tried to suppress Rahamna Tribesmen from besieging Marrakesh (ibid). As a consequence of these events, colonial opportunities arose for the great powers from the north of the Mediterranean.

Spain, after an attack by a squad of Riffian militants on one of its fortifications in Ceuta, responded by landing an army in Ceuta and occupying Tetuan in 1860 with British and French consent (Spanish War History 2012). The Treaty of Wad Ras (which ended the 1859-60 
Hispano-Moroccan War) not only cemented Spanish control of Ceuta and Tetuan, but also "secured from Morocco the town of Ifni, near Cape Nun on the Atlantic coast" (Johnston 1966, 63). Several authors (ibid., 120-121) write of the weakness of Muhammad IV as he attempted to deflect the eyes of the European powers away from its "tempting geographic position" and "lying along essential maritime routes" (Julien 1970, 271). However, the importance of the Straits of Gibraltar, located at one of the major transportation intersections of the world, did little to diminish European interests. In addition, his primary advisers were "divided amongst those who saw all that was happening as a result of European penetration and who urged adherence to a rigid, traditional, anti-European attitude and those who believed that it was necessary to modernize and to improve the administration" (Johnson 1976, 123). Laroui, tellingly, summarizes the state in which Morocco found itself by asserting, "that the sultan's independence and the integrity of his territory were safeguarded not by the Moroccan army, which was disorganized and poorly equipped, but by the protection of the English" (i.e, the British diplomatic corps) (1977, 317).

Historical documentation generally indicated that in the southwest of Morocco, in the area of the Sous, and further south into the Oued Dra'a, there appeared to be a loosening of control by the Sultan at the time (late nineteenth century) of these crises. One important tribe is the Tekna mentioned previously in chapter five. The Tekna claim links to the Almoravid Empire that stretched from what is now Morocco to the southeastern peripheries of the Sahara adjacent to the ancient Ghana empire and their present-day connections to the Sahrawi. As a historical note and mentioned briefly in chapter three, the Sanhaja family of Berbers ${ }^{226}$ of the twelfth century were sub-divided among several groups of tribes - the Hawwara, Lawata, Lamtuna, Massufa, and

\footnotetext{
${ }^{226}$ As a note of remembrance, the ancient Berbers were divided among several family of Berber tribes - the Sanhaja, Masmuda, and Zenaga. Ilahiane, 109.
} 
Guddala. The Almoravids, a hodgepodge of "Lemtoûna" 227 [or Lamtuna] (Doutté 1914, 344), Guddala, and other tribes that gravitated from the southwestern Atlantic coast of North Africa, picked up converts, and traveled north to modern Morocco. Other scholars believe that the Tekna are a mix of either Lamta (De La Chapelle 1930, 50) or descendants of the Gazula (Lydon 2009, 173-174; Norris 1986, 142, 145). However, most scholars conclude that the Tekna were the "earliest inhabitants of the Wad Nun" (ibid., 173). The result, evident according to POLISARIO proponents, are that those members of the present-day Tekna Confederation now located in southern Morocco and Western Sahara proper (including some refugees that inhabit the Algerian camps near Tindouf) compose part of the Sahrawi nation.

Chapter five documents how the "país Tekna" (the Tekna nation) (Martinez Milán 2007, 367) and a certain personality, Shaykh Beyruk (1815-1859), of the Ait Moussa Ou Ali of the Tekna Confederacy came to prominence in the early part of the nineteenth century (see map 6.2) and ruled with autonomy (Pazzanita 2006, 408), free from the control of the Sultan, in the Oued Nun from the city of Guelmime (Lydon 2009, 164, 174-175). He, along with his sons thereafter, attempted at various times to create a commercial port in Tarfaya (Cape, or Cabo in Spanish, Juby). (ibid., 167-169; Pennell 2000, 100-101; Ould Mohamed 2010, 248-249 note 9). Both Shaykh Beyruk and Sidi Hashem had tried to establish trading posts along the Atlantic coast with the Europeans in order to circumvent taxes on trade levied by the Moroccan Sultan (Hodges 1983, 32). Sidi Hashem was the Sharif ${ }^{228}$ of Iligh in the Tazeroualt ${ }^{229}$ oasis on the edge of the

\footnotetext{
${ }^{227}$ Taken from the French and translated by Dr. Maria Antonieta Garcia: "Hier matin nous avons quitté avec plaisir ce campement peu agréable. Pendant deux ou trois heures, nous marchons encore sur le territoire de cette tribu de chenapans; les Tekna sont de hardis voleurs, ils sèment au loin la terreur le caïd : dit-on, a sa part de leurs rapines. Zélaleurs fanatiques, pillards éhontés, vagabonds incorrigibles, ils évoquent le souvenir des Sahariens dont les hordes envahirent cette même région du H'oûz il y a bien des siècles : les Tekna d'aujourd'hui sont des Almoravides. C'est bien ainsi qu'étaient les compagnons de Ioûcef ben Tâchfîn, les Lemtoûna au visage violé, venus des profondeurs du Sahara...," Edmond Doutté, Mission au Maroc: En Tribu. Paris: Librairie Paul Geuthner, 1914.

${ }^{228}$ Sharif in Arabic denotes "noble" or "high-born." An Arabic title of respect, restricted, after the advent of Islam, to members of Muhammad's clan of Hāshim. Encyclopedia Britannica Online, s.v. 'Sharif' May 9, 2014 http:/www.britannica.com/topic/sharif, Accessed October 16 2015. "In several cases, Sharifian descent was part of a dynasty's title to rule...Most important of all for the history of Africa south of the Sahara were the Sharifian
} 


\section{LEGEND}

Limits of Tazeroualt
Limits of the Beyruk Territory
Limits of the Tekna Territory
Limits of Ait Bu Amran Territory
$27^{\circ} 40^{\prime}$ Morocco/W Sahara Frontier
Legend translated from the Spanish

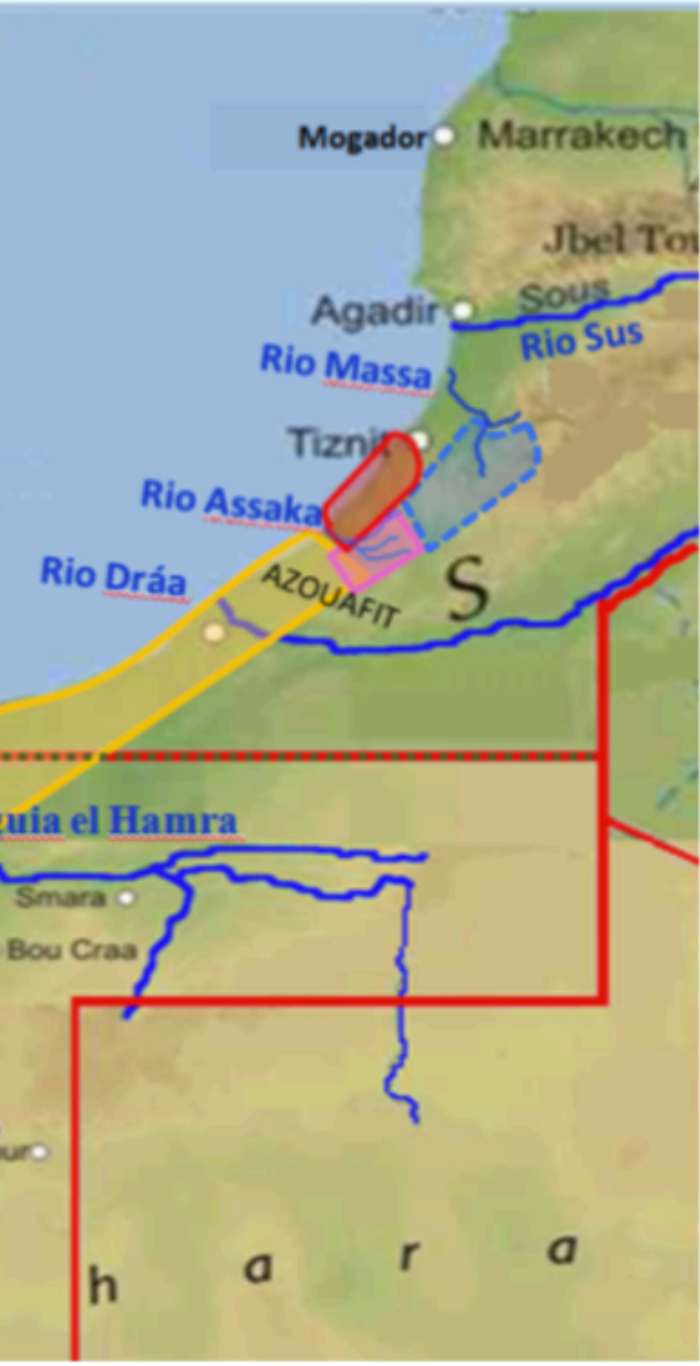

\section{Map 6.2: Tazeroualt, the 'State' of Beyruk and Tekna ${ }^{230}$}

Sahara Desert. Lenz, who visited Morocco in 1880, stated, "Sidi Husayn, an old black man who ruled the area as an independent prince, maintained an army of five thousand slaves, all black from different backgrounds in West Africa, including the Fulani” [Emphasis added] (Lenz 2013,

pretensions of the "Alawi dynasty of Morocco." H. J. Fisher, "The Eastern Maghrib and the Central Sudan, in Roland Oliver, ed., The Cambridge History of Africa 3, (Cambridge: Cambridge University Press) 1977, 314-315.

\footnotetext{
${ }^{229}$ Tazeroualt is also found spelled as Tazerwalt, Tazarwalt, or Tazerualt (in Spanish).
}

${ }^{230}$ Map is adapted and translated by the author directly from the Spanish in José Carlos López-Pozas Lanuza, "África Occidental Española: La Cuestión de Soberanía y La Retirada del Sahara” (Ph.D. diss., Instituto Universitario General Mellado, 2015), 313. 
251). 'Sidi Husayn' is the same Sidi Hashem of Iligh mentioned above. His given name would be Sidi Husayn Bin (or Ben) Hashem (1842-1886) based in the city of Iligh, which was found in the Tazeroualt (region). Curiously, although Pennell writes that the Iligh Sharif had acquired great economic autonomy, he adds that he was not the kind of leader that would lead a rebellion against the sultan (Pennell 2000, 26). Then in the following paragraph, he states that neither Sidi Hashem nor Shaykh Beyruk were a threat to the sultan (ibid.). In fact, Sultan Moulay Hassan I (18731894) would ask other leaders of the area to intervene, such as Sidi Hashem, to try to influence and rein "in Beyruk and [David] Mackenzie, but Husayn [bin Hashem] was a very autonomous subject and was negotiating on his own account with French and German representatives" (ibid., 101).

In addition to the odd juxtaposition of these sentences, it is questionable why these leaders would want to initiate a full-scale war with the sultan's armies in the first place. It would have interrupted their successful business enterprises and only then evoked the ire of the Kingdom's forces. Still, trade negotiations with the Europeans by Beyruk (1835-36, 1840, 1845, and 1853) and Sidi Hashem proved unsuccessful and were permanently discarded when Sultan Moulay Abderrahmane co-opted the shaykhs and his sons away from the influence of the British and the French. ${ }^{231}$ Still, these failures did not prevent other tribal entities from initiating commercial endeavors with the French farther south in the Senegal River Valley. Again though, instead of maintaining these agreements, the French expanded up the Senegal in order to seize control of the acacia gum trade away from the Emirates of Trarza, Brakna, and the Tagant. Eventually, France defeated the Moorish Emirates, including the Kingdom of Waalo, which was located south of the Senegal River.

In an interesting and severe criticism of European ethnography by colonial adventurers and travelers, Hasan Mohamed ponders how a major qabila (or coalition of tribes), such as the

\footnotetext{
${ }^{231}$ However, the Sultan did finally concede to Shaykh Beyruk a trading house in 1844 at Mogador.
} 
Tekna, could have been left to negotiate with Europeans, and possibly displacing, the caravan trade. He indignantly asserts "it is difficult to imagine how the Bayruk could have been shortsighted to the extent that they would risk confrontation with the Alawite court in return for access to European markets that have no use for their slaves" (due to the abolitionist movement that initiated in England) (Hasan Mohamed 2012, 277). The Alawite Kingdom would dote on the Tekna with "a system of patronage... with lavish distribution of 'decrees of respect' to" the zawaya [religious] power centers to secure the security of trade routes "over the 'qabila [Beyruk] ensembles"” (ibid., 138-140). In addition, H. Mohammed makes the very arduous and methodical case that the claims of Tekna origins to the Sous and the wider Oued Nun region, are documented from outside observers. He is also doubtful of the Tekna's homogeneous ancestry for in the least, they are a series of hybridized foreign bloodlines-Arab, Berber, and possibly even Moorish. As such, he criticizes all the aforementioned scholars for 'mistranslating' the 'tribe' and objectifying 'libertarian' concepts incorrectly associated with the Tekna and the Shaykh Beyruk. Furthermore, he states that the Tekna's "notions of origin were often authored by 'foreign elites' such as the Beyruk," thus relying heavily on Arabic and other ancient Saharan sources, such as Ibn Khaldun (ibid., 210).

Hassan Mohamed's critique implies that the Moroccan Sultan did have control of Shaykh Beyruk and that the Tekna were not native to the Oued Nun or Sous Valleys in the late nineteenth century. He also suggests that the Tekna were not independent. This argument will prevent the use of the Tekna as a perennial ancestor to the Sahrawi because the POLISARIO have argued that they have always been free of any Sultan. More study would be needed to understand how the Tekna viewed themselves at that time. Yet, the POLSARIO, based on the several interviews conducted in Rabouni Camp, acknowledge that they are a mix of different identities. The problem with that notion is that there is uncertainty over which tribe or tribes to use in order to properly trace the origins of the Sahrawi. The only alternative is to consider all regional tribes as possible 
candidates. Yet, another problem arises: how many tribes and how far the region should one include? Are the tribes in and around the Sous, Nun, Dra'a, and Sequiet al-Hamra the only viable contenders? Or is it necessary to study all tribes of the greater western Sahara: nomadic and sedentary and across modern frontiers (Mali, Mauritania, and Morocco)? More investigation is needed that is beyond the scope of this study.

However, despite Hasan Mohamed's aversion to European 'misconceptions, he does conclude that the Beyruk became originators of their own history (and that of the Tekna), because "of the frequency of their encounters with the outside world, and ability to accumulate resources and concentrate power" (Hasan Mohamed 2012, 210). Rézette indicates that their loss of independence was actually the result of the threat posed by the Spanish Monarchy in attempting to establish a port of trade somewhere "between the Wadi Noun and Agadir," which "seemed to them to correspond exactly to the old Santa Cruz de Mar Pequeña" $(1975,58)$. Both the threat and these 'dissident' tribes were thus met with force by the Sultanate. The Sultan would invade and leave garrisons of armies, loyal to him, to maintain order. For example, in 1882, Sultan Moulay Hassan I, marched with an overwhelming mass of troops, numbering between 40,000 to 70,000, from Marrakesh to Guelmime "to appease the appetites of the local chiefs" and crush the aspirations of these independent rulers (ibid.). It is hardly surprising to read from Rézette that the defeated 'tribes' notables came to affirm their loyalty to him and to promise to oppose European movements" (Rézette 1975, 58). Pennell, who seems to lean on the more official side of Moroccan history, affirms that the 'dissident' or bilad al-siba areas "still recognized the Sultan, even if they took little notice of him in daily affairs" $(2000,28)$. Yet, he admits earlier: "Otherwise, the Sultan was content to let the remoter regions well enough alone, since it was too expensive to maintain direct control over unproductive areas. He only required that the caravans get through, that bandits should not close the roads and, above all, that his leadership of the 
community be recognized in the Friday prayers" (ibid.). None of these interactions though gave the tribal confederations impetus for 'national' cohesion.

This is similar to what many around the world perceived as American military, political, and possible economic domination of global affairs after World War II. Yet, the United States would affirm that it would not become embroiled in any sovereign country or region unless it had a vested national interest for such intervention. The United States would undoubtedly defend its well-demarcated geographical borders. In contrast, nineteenth-century Morocco had ill-defined frontiers and 'invasions' into the Sultan's land were subjective. However, similar to the Sultanate, the U.S. would most likely only become involved in key transit or economic zones (South China Sea, Panama Canal) because of the importance in international commerce. Otherwise, America, too, would deem it far too expensive to maintain direct control of all trade routes, and would prefer 'to let these' more remote regions 'well enough alone.' The problem with these statements is rooted in the socio-cultural environment of the day. The modern-day Westphalian concept of the nation-state does not provide one with an accurate description or characterization of the 'nation' of Morocco in a North African setting during the Sa'adian and Alawite Dynasties, depicted by historians such as Pennell.

The modern era invites this analogy but only because the United States is a well-defined, territorially fixed nation-state, whereas the Sultanate of nineteenth century Morocco cannot be well defined in twenty-first century fashion. The only group identities, outside of the tribal, were those fashioned by the regional leaders, such as Shaykh Beyruk, Sidi Hashem, and Sultan Moulay Hassan I. If the Westphalian concept of the modern nation-state were to recognize titles of spiritual investiture as criteria for statehood, the Vatican would surely inherit millions of adherents across dozens of states. It would result in the reemergence of an 'Holy Empire' never before seen. Yet, no one today would agree to such a notion. Even Criado will argue that in the nineteenth century, 'decrees of respect,' 'occasional affirmations of loyalty' by other tribes 
(Pennell 2000, 100), or letters of investiture and acknowledgement by the Alawite Sultans did not signify that their power extended over all tribes. He states "it was a type of propaganda without efficacy, intended to produce the illusion of a domain with no real existence ${ }^{, 232}$ (Criado 1977, 90). It is difficult to assert that a Sahrawi national identity had emerged at this time. The only verifiable (group) identities were those socio-political entities established by dynastic and tribal leaders.

\section{Independent Entities in the Northwestern Sahara}

The autonomous entities described in the following provide examples of group identities that developed at the end of the nineteenth and early twentieth centuries in and around modern Western Sahara. It gives an account of certain groups that had already established a cohesive identity, independent of the Sultanate. It tries to establish a possible link from some of these tribal confederations to the emergence of Sahrawi national identity. It also introduces the debate over autonomy and its relation to national identity. If documenting the correct set of tribes does not help in seeking the origins of Sahrawi identity, then perhaps territorial autonomy can be a better tool.

For instance, a publication by La Presse (Parisian Daily) written in 1844 of June 14 reads: "At the beginning of last century, Morocco still extended its authority down to Tombouctou in the Sahara, but its influence decreases every day, especially since 1795; most of the kingdom of Sous was detached from the empire of Morocco to form the independent state of Sydy-Hecham"233 (4). Caratini, states, "the economic power of the Tekna of the Oued Nun had developed in relation to Tazeroualt. This state, created, at the time of the decline of Sa'adians, around the seaport of Masa,

\footnotetext{
${ }^{232}$ Taken from the Spanish: "se trataba de una especie de propaganda sin eficacia, destinada a producir la ilusión de un dominio sin existencia real.” Ramón Criado, 1977, 90.

${ }^{233}$ Taken from the French and translated by Dr. Maria Antonieta Garcia: Au commencement du siècle dernier, le Maroc étendait encore son autorité jusqu'à Tombouctou dans le Sahara, mais son influence diminue tous les jours, surtout depuis 1795; une grande partie du royaume de Sous s'est détachée de l'empire de Maroc pour former l'état indépendant de Sydy-Hecham. "Nouvelles et Faits Divers," La Presse, June 14, 1844, Gallica.bnf.fr. Accessed August $12,2015$.
} 
is, intermittently, independent of sharifian authority" before $1765(1989,80) .^{234}$ In another reference, Désiré-Vuillemin states, "the 'great nomads' are especially the Reguibayt (Sahel and Lgouacem), Oulad Delim, but their cousins Tekna are 'lessor [or junior] nomads' — herders. They live between the confines [or frontiers] of Morocco and the Adrar (See map 6.4), far from any authority" [Emphasis added] ${ }^{235}(1962,55)$. The ICJ, in their 1975 Advisory Opinion on the Western Sahara, stated "although Morocco asserts that the Regheibat tribe always recognized the suzerainty of the Tekna Confederation, and through them that of the Sultan himself, this assertion has not been supported by any convincing evidence" (48). However, later in this report, the ICJ equivocated and acknowledged that:

Those Tekna septs ${ }^{236}$ in their nomadic journeys spent periods of time within the territory of the caids ${ }^{237}$ of the Tekna confederation appears, however, to the Court to lend support to the view that they were subject, at least in some measure, to the authority of Tekna caids...Furthermore, the material before the Court contains various indications of some projection of the Sultan's authority to certain Tekna tribes or septs nomadizing in Western Sahara ${ }^{238}$ (ibid.).

Despite the independent attributes identified by some of these scholars, the Tekna have historically demonstrated the closest ties to the Sultanate of Morocco (Deubel 2010, 67).

Thus far, the most important point here is that each tribe had already developed a sense of

\footnotetext{
${ }^{234}$ Translated from the French and translated by Dr. Maria Antonieta Garcia: La puissance économique des Takna du wad Nun s'était développé en relation avec le Tazarwalt. Cet État, créé, au moment de la décadence des Sa'adiens, autour du port maritime de Massa, est, par intermittence, indépendant du pouvoir chérifien. Sophie Caratini, Les Rgaybat (1610-1934) : Des Chameliers a la Conquete D'un Territoire, Tome 1. Paris: L'Harmattan, 1989, 80.

${ }^{235}$ Translated from the French and translated by Dr. Maria Antonieta Garcia: Les 'grands nomades' sont spécialement les Regueibat (Sahel et Lgouacem), O. Delim, mais leurs cousins Tekna sont 'petits nomades' moutonniers. Ils vivent entre les confins marocains et l'Adrar, loin de toute autorité. Geneviève Désiré-Vuillemin, “Contribution a L'Histoire de la Mauritanie de 1900 a 1934,” Ph.D. Diss., Université de Montpellier, 1962, 55.

${ }^{236}$ Sept is a term used mostly in Irish and Scottish culture signifying folds (divisions within a family) or clans.

${ }^{237}$ Caids

${ }^{238}$ Such material includes documents relating to the recovery of shipwrecked seamen and other foreigners held captive by Teknas in Western Sahara... or documents showing that on some occasions, notably the Sultan's visit in 1882 and 1886, he received the allegiance of certain nomadic tribes which came from Western Sahara... and in letters from the Sultan to Tekna caids requesting the performance of certain acts to the south of the Noun and the Dra'a. Sahara Occidental (Reports of Judgments, Advisory Opinions and Orders) ICJ Advisory Opinion of 16 October 1975, 48.
} 
separateness despite being subject or non-subject to the Sultan. They had distinguished themselves by self-government even if this charge was through devolution of power. Tribes had developed trade hubs and were willing to exchange goods with the Europeans in spite of Moroccan challenges. These social interactions provided stability and autonomy, which was attached to territory, mostly with the more sedentary tribes. Tribal identity was strong but the sense of a national identity was absent. Affinities were still very localized. There certainly were several emerging tribal identities but not one that can be described as Sahrawi.

There is an ambiguity to the domain of the Sultanate over areas predominantly controlled by the Tekna confederation in the Oued Nun, Sous River Valley extending to the Sequiet alHamra. These ambiguities pose a challenge to defining domains by political groups. If the task of defining the territorial control of a political group in an environment of competition and intrigue is challenging, how much more difficult can it be for identifying the roots of a nation? The Tekna, descendants of the Almoravids and presently claimed by the POLSARIO to be the ancestors of the Sahrawi, despite having once been subjugated and under the control of others (as confirmed by the many scholarly sources) developed a 'nation'—an established geographical area, commercial system, and a sedentary, semi-nomadic, and nomadic way of life, with a small ruling political system. Yet, the author of this work does not yet find strong evidence for an awareness of 'Sahrawiness' or a defined Sahrawi identification, much less the establishment of the Saharawi nation. On the contrary there were an abundance of tribal entities. The lack of Sahrawi national presence in this period and in the preceding chapters does not preclude the fact that their origins emerged from such historical accounts; the results of which are grounded in constructivist arguments.

Another approach that could have shed some light on the creation of older 'nations' is a sub-field of primordialism-perennialism. For instance, the Tekna (see map 6.3), Reguibayt, Tajakant, Oulad Delim, and those tribes farther south in Tiris, Zemmour, the Adrar, and Brakna 
all have, to a degree, descended from Sanhaja Berbers. (see chapter three) These descendants intermarried with Arabs and split into the several branches of the Sanhaja. The POLISARIO have claimed that these tribes or at least the greater part of their composition belong to the Sahrawi nation. These arguments may be derived from the idea that nations may be evident since antiquity, or recurrent, disappearing but reappearing at a later time in a different fashion. Most of these perennial arguments though seem to only fit verifiable, strong and established groups such as the Jews, Greeks, Egyptians, who were present in antiquity and still exist today. 5,000 years ago, there had not yet been one Sahrawi. Evidently, these arguments do not fit in the Sahrawi case.

Furthermore, there are reports that acknowledge the independence of not only the Tekna Confederation but also many other independencies. One example of a political entity that developed alongside the Tekna (see map 6.3) and the Moroccan 'Empire' are the Reguibayt. The Reguibayt were "[h]eirs of the baraka of their eponymous ancestor, Sharif Sid Ahmed Reguibi established in the Seguiet el-Hamra in the XVI century"239 (Beslay 1984, 84). Scholars have not agreed as to the origins or even the birth of their legendary founder of the Reguibayt. In fact, there is even disagreement as to the actual territory that was controlled by this tribe. Criado writes that, according to Mamadu Ahmadu Ba, "During its history, the Erguibat were never under foreign domination. Politically, they were always independent of the Mauritanian emirs as the Tekna caids' representatives of His Sharifian Majesty in the rejected southern Anti-Atlas"240 (1977, 90). Zunes and Mundy have also stated that the Reguibayt had always rejected the Sultan's suzerainty (2010). Yet today, even though "the base of support for the POLISARIO is

\footnotetext{
${ }^{239}$ Translated from the French and translated by Dr. Maria Antonieta Garcia: Héretiers de la baraka de leur ancêtre éponyme, le chérif Sid Ahmed Reguibi établi dans la Seguiet el-Hamra au XVI siècle. François Beslay, Les Reguibats: De la Paix Française au Front POLISARIO, Paris: L'Harmattan, 1984, 82.

${ }^{240}$ Taken from the Spanish and translated by the author: "Durante su historia, los Erguibat no fueron jamás sometidos a dominación extranjera. Políticamente, fueron siempre independientes de los emires mauritanos como de los caids tekna representantes del su Majestad Cherifiana en el sur del Antiatlas."
} 
Map 6.3: Morocco 1894: Sultanate of Morocco and Rio de Oro Colony ${ }^{241}$

among some of the Reguibat tribes of the east...the Reguibat tribes in the western part of the [Western Sahara] territory as well as the Tekna confederation are largely pro-Moroccan." [Emphasis added] (Pham 2010, 16).

There is also documentation of tribes that settled and established small villages, then cities without the direction of a regional leader, but far outside the sovereign control of the Moroccan Sultan. For instance, as mentioned in the previous chapter, the Tajakant who enjoyed nomadic living in the Adrar, once held the abandoned oasis of Tinigi. However, after being ousted by the Reguibayt, they established the Saharan city of Tindouf that later became a central caravan hub (Lydon 2009, 155). ${ }^{242}$ In fact, the Tekna, recognizing the Tajakant's value to trading, became allied to them by the late 1850s. There were also Hassani (mostly Arab) tribes that "triumphed in the beginning of the eighteenth century over the Ideyeselli, who until then dominated the oases and grazing grounds of Adrar... [and] represented in that period a unity of tribes with segmentary lineages" (Bonte 1981, 46). The authors state that these tribes later organized themselves as a Moorish Emiral state around the Emiral lineage of Shaykh Ahel Etman (Bonte, 48). In addition, Pennell describes how, despite the nomination in 1882-84 by the Moroccan Sultan, Moulay Hassan I, of a local khalifa "over the Figuig oases, and in 1892 a local administrator over the Touat...the population ${ }^{243}$ refused either to pay taxes or to recognize the

\footnotetext{
${ }^{241}$ Translated from the Spanish and translated by the author: "Marruecos 1894: Sultanato de Marruecos y Colonia Río de Oro-Poderes Reales/Imperiales,” Euroatlas.net, 2014. http://www.euratlas.net/index en.html. Accessed July 31, 2015. http://www.euratlas.net/history/hisatlas/africa/es 1894marocTRZ.html.

${ }^{242}$ Apparently, Tindouf was an important trading city that connected Oued Nun, Tazeroualt, Tafilalet, and the oasis of Tuat. Lydon On Trans-Saharan Trails, 155.

243 This refusal by the population may have been in part to support the Algerian rebel leader, Bu Amaran, as these communities resided on the Algerian-Moroccan frontier. Pennell, on the other hand, will state "in the Sous, local leaders undermined the Makhzan's authority not by fighting but by trading with the Europeans." However, it is unclear
} 
authority of the Sultan's qaids" (Pennell 2000, 100).

The absence of sovereign control over the peripheral areas surrounding Morocco allowed for the independent tribes to flourish and create their principalities. It allowed for the development of distinct tribal identities. It also alters the nomadic lifestyle of some tribes, now even in the deep south. The major northern tribes of the Western Sahara such as the Tekna, Reguibayt, and Tajakant become urban and more powerful. The smaller tribes seek alliances. These examples demonstrate that there was no one 'national' identity that bonded all tribes; they had become self-sufficient, autonomous. In fact, tribes fractured through conflict, divisions, or because of demographic agricultural limitations. They also merged because of conquest, through inter-breeding, or the loss of grazing and water shortages necessitating alliance with others. Tribal identities, at least for smaller tribes shifted. Although these examples provide glimpses of territorially-independent tribal identities, they still do not prove that there was evidence of a grand Saharan, or much less, Sahrawi 'national' identity. In the southern extremities of the Western Sahara, similar developments are taking place.

Independent Entities in the Southwestern Sahara

In 1724, Moulay Ismail "sent an army to support southern Saharan Arabs against the French along the Senegal River" (Cleaveland 2002, 99). However, this would become one of the last instances in which a Sultan would be able to intervene in the politics of the southwestern Sahara. A detailed study on the Walati, ${ }^{244}$ confirms that this was another decidedly independent region with rich history. "An early twentieth-century Walati chronicle conferred on Mulay Ismail and the other Alawi sultans the title of Amir al-Mu'minin (Commander of the Faithful)" [Emphasis

and still would require much more study as to the nature of the makhzen (Moroccan administration) authority. Morocco since 1830 ,

${ }^{244}$ Walati were a "people from the Saharan oasis called Walata or Oulata, which is about 300 hundred kilometers west from Timbuktu." Walata is located in present-day southeastern Mauritania. Timothy Cleaveland, Becoming Walata: A History of Saharan Social Formation and Transformation (Portsmouth, NH: Heineman, 2002), xix. 
added] (ibid.). However, Cleaveland adds that this same chronicler, along with other Walati leaders had publicly "submitted to Ahmad, the son of Fulani jihadist 'Umar Tal, in 1873, describing both as commanders of the faithful" [Emphasis added] (Cleaveland, 99). The Walati chronicles "leave the reader with the impression that Walatis never considered themselves part of the Sa'adian or Alawi domains, and give much more attention to the Ruma ${ }^{245}$ [or arma] regime in Timbuktu $^{246}$ and Fulani politics in Masina” (ibid.). In fact, based on scholarship outside the scope of this study and other oral histories, there were several independent confederations that rose, fought, and declined in the Tagant, the area surrounding the town of Walata, and in the Hawd $^{247}$ (ibid., 103-104).

Lydon speaks of certain regional Emirs (see map 6.4) that came to power in the southwestern and southern Saharan. Ahmad Mawlud Wuld 'Abd al-Wadud Wuld Intaha's describes this period of relative stability:

The coming to power of (the Emir of Adrar) Ahmad Wuld Muhammad (a.k.a. Lemhammad) Wuld 'Abdy. He was just and he entertained good relations with Bakar Wuld Swayd Ahmad (Idawish Emir of Taganit) and 'Aly Wuld Muhammad Lahbib (Emir of Trarza) and Muhammad Mahmud Lahaymid (Emir of Brakna) and Dahman Wuld Bayruk (Tikna leader of Guelmim in Wad Nun) and Mulay al-Hasan (Sultan of Morocco $)^{248}(2009,127-128)$.

\footnotetext{
${ }^{245}$ The Arabic term ruma(h), translated as 'musketeers' in English, is the plural form of rami (shooter), the name given to the combined Sa'adian army of Sultan Ahmad al-Mansur of "Spanish, Berber, and Arab mercenary soldiers who participated in the Moroccan conquest of Timbuktu in 1591." This army settled and mixed "with the local elites, becoming the ruling caste." John O. Hunwick and Alida Jay Boye, The Hidden Treasures of Timbuktu: Historic city of Islamic Africa, London (Thames \& Hudson) 2008, 154. Al-rumah later passed into Songhay as arma, the term used for the Moroccan ruling elite in Timbuktu post-1591, whose descendants still form a social class. John O. Hunwick, edited, Timbuktu and the Songhay Empire: Al-Sa'di's Ta'rikh Al-Sudan Down to 1613 and Other Contemporary Documents (Boston: Brill, 1999), 166, 197.

${ }^{246}$ Ahmad al-Mansur's march south toward the southern fringes of the Sahara defeated the Songhay Empire, and subsequently, the Arma or al-rumah (in Arabic) administration that was established by the Sa'adian Sultan became independent of his rule by 1618 .

247 The Hawd is a term that means 'Arabic for 'basin,' and refers to the regions' lower topography in relations to the neighboring Tagant highlands, and the elevated plateau to the north and northwest, respectively. In Saharan narratives, the Hawd was the 'end of the line,' one of the last regions where groups claiming Arab origins exerted hegemony over indigenous farmers and herders." John H. Hanson, Migration, Jihad, and Muslim Authority in West Africa: The Futanke Colonies in Karta, (Indianapolis: Inmdian University Press) 1996, 49.

${ }^{248}$ Ahmad Mawlud Wuld 'Abd al-Wadud Wuld Intaha. Ta'rikh Adrar, Manuscript by his son Jilil b. 'Abd al-Qadar b. Intaha (1934) quoted in Lydon, Trans-Saharan Trails, 127-128.
} 
The Adrari Emir Lemhammad is claimed to have "brought relative peace and great prosperity, assisted by several years of abundant rains" to the region (ibid., 127). Indeed, Lydon 


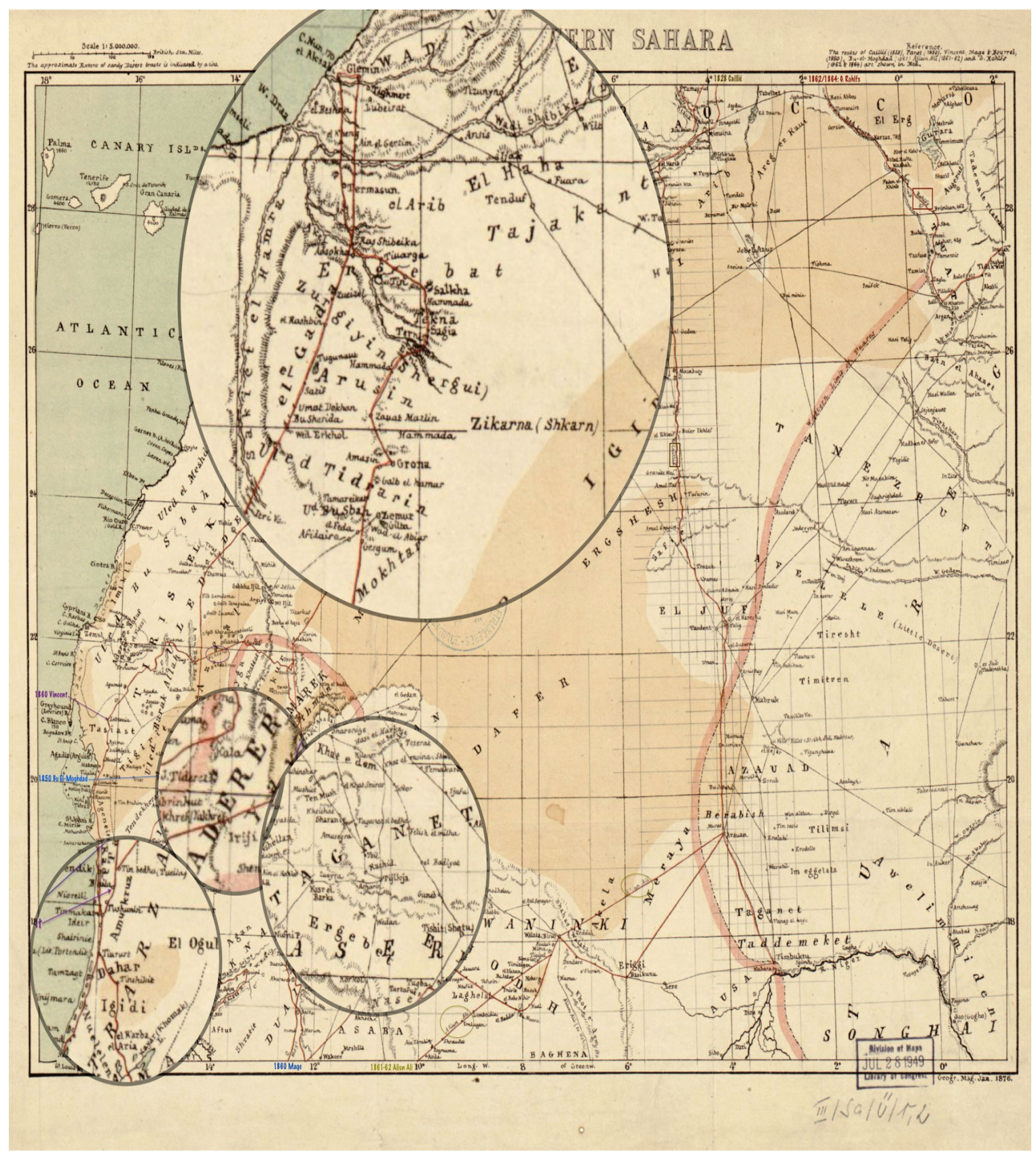

Map 6.4: 1876 Map of the Western Sahara 249

249 This map shows, magnified within the westernmost red lines, 1) the "Aderer" or Adrar Emirate; 2) At the southwestern-most point, the Trarza Emirate; 3) To the east and last to be formed, the Emirate of the Tagant; 4) Finally, due north are the independencies of the 'Uled' Tidrarin, the Arusin (otherwise known as the Arosien Tribe), the Ergrebat (or in this study spelled as the Reguibayt), and the Tajakant located south and southeast of the 'Wad' Nun and the Sakiat el Hamra River Valleys. (Not magnified but on the map is also the Emirate of Brakna) E. G. Ravenstein, "The Western Sahara," in Sir Clements R. Markham, ed., The Geographical Magazine III (Trubner and Company: London), January 1 1876, 12. Google Play Books. 
also adds that Emir Lemhammad signed several agreements "with Dahman bin Beyruk, then the Tikna ruler of Guelmim" (2009, 127). Bonte reports "the 'customs' paid by the French merchants to the Moorish chiefs...strongly reinforced the powers of the emirs" $(1981,46)$. McDougall and Steele describe that, "by the mid- to late eighteenth century, it is clear that the sultan's interests in the region (Tegaza to Timbuktu) remained strong; moreover, his authority was recognized as legitimate by at least some important Saharans" [Emphasis added] $(2012,52)$. However, a correspondence with the Sultan of Morocco about tariffs on salt, explains: "The famous shaykh Sidi al-Mukhtar al-Kunti claimed that the Kunta ${ }^{250}$ should be exempt from paying salt taxes not because the sultan had no right to levy them in the first place, but because as a respected family of venerated saints, the Kunta should answer to no secular authority, such as Moroccan representatives, or qa'ids" (McDougall and Steele 2012, 52).

McDougall and Scheele reveal details on specific autonomous entities by exploring their caravan trade networks (ibid., 44-45). Lydon used a diaspora framework that centered on the growth and fluctuation of trade routes, which originated in the Tekna heartland in southern Morocco, to exert control over the Western Sahara. Alternatively, Norris saw control of the Sahara as part of the Arab mentality of conquest through "the agency of local Saharans" (A. McDougall 2012, 45). Control over the southwestern Sahara, even in the late nineteenth century was still in doubt and indicates that the Sultan could not have had proper dominion over these territories. As a result, Morocco's King today, cannot claim that these lands have been historically apart of the Kingdom. Still, there was no Sahrawi Emirate or Emir that was building a conglomeration of Saharan tribes.

\footnotetext{
${ }^{250}$ It is important to mention that the Kunta were not always of one mind. "During the same historical moment (purportedly ca. 1766-1767) mentioned above, a western branch of the Kunta family claimed ownership of the Ijil mine-but reportedly, only after seeking approval from the Moroccan Sultan." E. Ann McDougall, "On Being Saharan," in James McDougall and Judith Scheele, eds., Saharan Frontiers: Space and Mobility in Northwest Africa, (Indianapolis: Indiana University Press, 2012), 52.
} 
Rather, there appear to be several independently flourishing, not just semi-nomadic tribal confederations but sedentary principalities in the Western Sahara along the Atlantic coast from south of the Sous River Valley to the vicinity of the Senegal River. The Hassaniya language, the practice of pastoralism (for those more semi-sedentary), nomadism and semi-nomadism, raiding, and Islam were all suitable features of identity that could have facilitated the union among tribes. Yet, there was no common bond that tied these tribes together as 'nation.' Identity remained tribal. In addition, despite disagreements among scholars about Moroccan authority over certain groups, tribes were already 'self-aware.' Tribal identity was tied to the family of clans, who participated in a separate sphere of local body politics distinct from wider 'Moroccan' aspirations. There is no evidence that these tribal communities were aware of a greater socio-political consciousness other than what was locally known to them. Thus, despite the relative independence of several tribal confederations, in and around modern Western Sahara, even among groups who the POLISARIO claim are 'pre-Sahrawi,' this did not feature as part of a Sahrawi autonomous identity.

\section{Conclusion}

There does not seem to be cohesive notions of 'Sahrawiness' in the latter half of the nineteenth century based on the features discussed in the introduction (Hassaniya vernacular, territorial affinity, and tribal autonomy) to this historical period. Seeking Sahrawi origins based on these elements of identity throughout history remains elusive. These elements of identity provide for group consciousness but it does not offer conclusive results for establishing a national identity. Rather than searching for the 'genesis' of origins as Armstrong refers to, perhaps it would be better to seek patterns or the persistence of ethnic attachments $(1982,4)$. These are, according to his typology, based on latent, conditioned, and framework attachments (ibid., 288). In other words, language, a nostalgia for nomadism, or the identification with one's group genealogy as a 
persistent feature of identity is key to building a nation. If then, there is no substantive evidence for a discernable Sahrawi identity at this time, what can be said is that there are latent attachments that have laid the groundwork for an identity.

For instance, the Jewish, Greek, and possibly Egyptian people can trace their origins to antiquity despite today's modern, re-conceptualized form of national identity. They feel proud of their ancient history, take care in restoring their symbols and heritage in spite of the gap in thousands of years of history. The same may be warranted for the modern Sahrawi. Underlying or layers of ethnic attachments begin to take hold and bond to the Saharan: a genealogical framework tied to the clan, then tribe, expanding to the confederation of tribes; a territorial affinity also perhaps tied to genealogical history. Group autonomy, not one of Armstrong's underlying attachments, serves to enhance group consciousness through patterns of collective management. The Sahrawi also speak a distinct form of Arabic called Hassaniya. These layers of identity have taken shape over time. If viewed in this sense, then we may find that origins of Sahrawi national identity have been taking shape all along and this period of analysis adds to their history. If these layers are viewed as mutually exclusive elements of identity, then one can only speak tribal identities at this juncture.

The constructivist hypothesis sought for socialization and historical forces that would combine cultural artifacts with social constructs. Socialization involved commerce exchange, conflict (ghazzian raids), political engagement (through agreements and accords with fellow Saharan tribes, including the Sultanate, and Europeans), and interactions with each other (alliances). These interactions were made by largely independent political entities; tribes that were autonomous. These tribes were led by either their shaykhs or emirs. The instrumentalist hypothesis, however, does not have much support in this period because no leader or group of elites resolved to unify all, or a majority of tribes, in the greater Western Sahara toward a greater cause for 'national' cohesion. 
A better conclusion rests in the knowledge that there have been several layers of identity developing over time. Social and historical forces have forged independent groups acting in opposition to or sometimes in conjunction with Europeans and the Sultanate. The ethno-cultural resources for identity have been identified but they have not fully merged with the leaders and elites of the disparate tribes. The tribes remain aloof from any 'national' objective. Identity remains local. The moment for the emergence of the Sahrawi has not yet become apparent but the groundwork (latent ethno-cultural elements) has been laid for the next historical period. 


\section{A NEW POPULATION EMERGES: THE DAWN OF THE SAHRAWI}

$(1884-1973)$

This chapter completes the socio-historical analysis through 1973. In 1973, the POLISARIO Front became the 'guardians' of the Sahrawi movement that today seeks to free the Western Sahara from Moroccan control. Initially established in 1973, the Front had garnered the support from much, if not all, of the 'Sahrawi' population. Its claims, in addition to those of scholars who report on the status of the Western Sahara, are based in part on a historical lineage of Sahrawi characteristics that fall in line with arguments from primordialism. As researched by the author of this work, these claims have been somewhat vague, inconsistent, and only serve to argue against the propriety of Moroccan control over the region. Moreover, evidence for a distinct group of Saharans that represented the region of the Western Sahara has been difficult to demonstrate. In fact, the research shows that there were several distinct groupings that represented political entities that inhabited the 'Greater Western Sahara.'

The question remains where the origins of Sahrawi identity lie. Primordial claims begin to take shape at this time, but they do not support one distinct group, namely the Sahrawi, but several independent political entities. The contention, an identity forged from the oppression and marginalization by the Moroccan state and/or the subjugation of colonialism, seem only more clear at the end of this period. The appropriation of Sahrawi identity by independence-seeking groups, such as the POLISARIO, may have been the key development that formalized a 'Sahrawi' identity. However, the constructivist premise that past and present day struggles formed the catalyst that helped to coalesce opposition groups will be discussed later in this chapter. It also incorporates the end solution created by the major powers at the end of the nineteenth century (1884-85 and 1906) that established borders (see map 7.1) and subsequently created 'international barriers' that interfered and divided both the long-established nomadic 


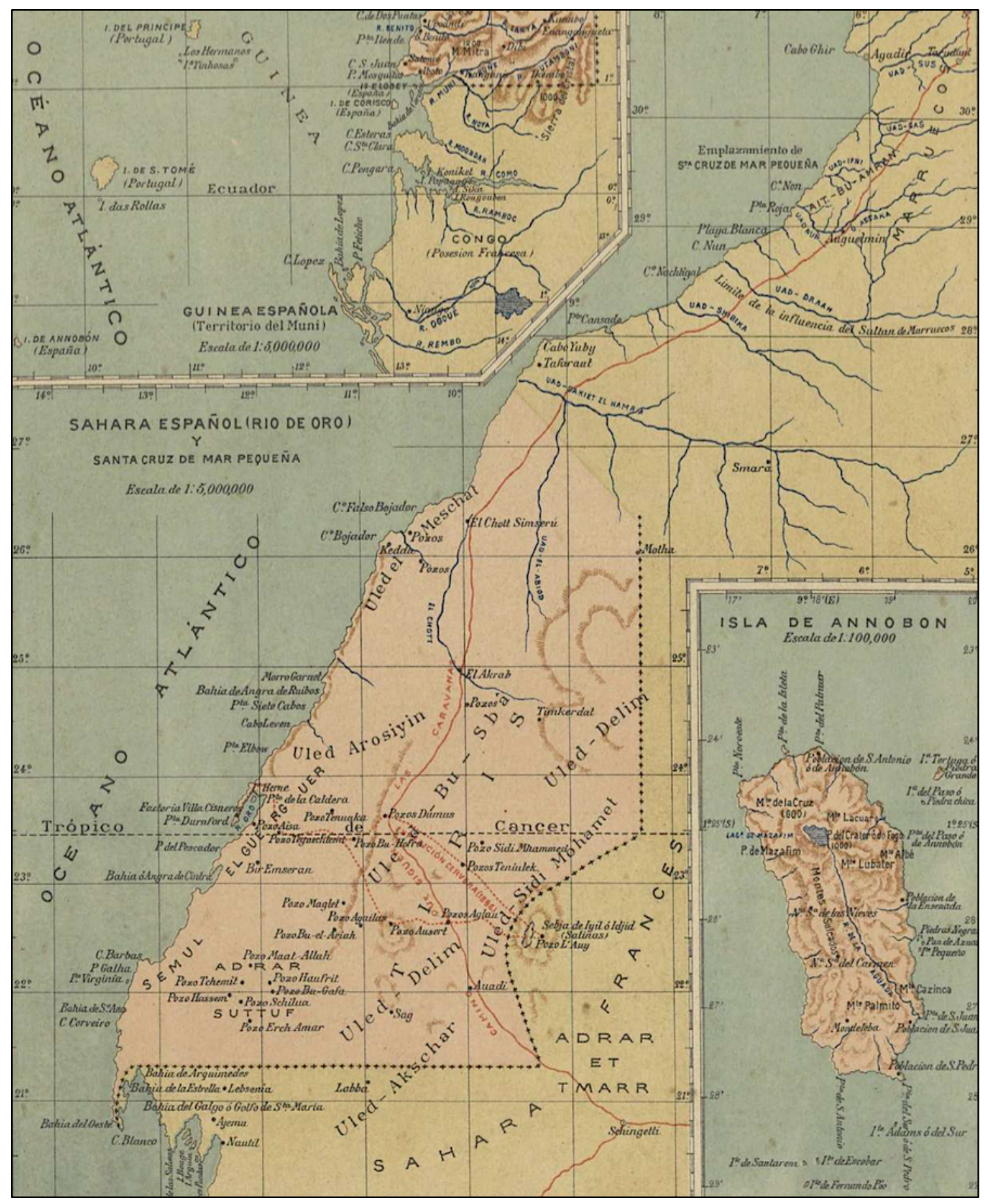

Map 7.1: The Spanish Sahara in $1903^{251}$

${ }^{251}$ Map Adapted and taken from Alberto Martin, "Posesiones Españolas en África: Costa Occidental (Sahara Español (Rio de Oro) y Sta. Cruz de Mar Pequeña, Golfo Guinea (Islas de Fernando-Póo, Annobón, Corisco y Elobey y Guinea Española (Territorio del Muni)), Barcelona, 1903. 
lifestyle and independence of those residing in the region. Research indicates that all these arguments are valid but a sense of group ONLY appealed about twenty years prior to the formation of the POLISARIO.

This chapter argues that ethno-cultural resources have been developing for some time. These features of identity, however have not adequately transformed the tribes of the Western Sahara into one cohesive national identity. The primordialist hypothesis is weak without more support. As the major European powers directly become involved in the colonization of the area, resistance begins. The constructivist hypothesis argues that opposition to European intrusion catapulted the union of many tribes and reaffirmed tribal independence. It will ask whether European colonization stimulated identity formation among the pre-Sahrawi in this last period of history. The instrumentalist argument will also be assessed with the account of Ma' al-'Aynayn and his followers. All three arguments can be examined in light of the dynamics of the period to determine of a Sahrawi nation emerges.

The Europeans Move Inland

If the preceding chapters failed to draw a clear picture of the origins of the Sahrawi, it is due to the ambiguous nature of the development of Sahrawi national identity. Moreover, just when Saharan history is re-oriented by independent political entities arising in the nineteenth century, Morocco's southern frontier became embroiled in further territorial disputes with Europeans who encroached into the interior of northwest Africa. The French had already begun limited engagements with the political entities at the southern fringes of the Western Sahara. Spain had at various times (January 1873,1883 , July 1885) attempted to gain ports of trade on the Atlantic coast of Morocco as compensation for the attacks waged by Rif tribes (supported by the Sultan) and against its northern territories (Ceuta, Melilla). The Sultan preferred to negotiate a financial settlement with Spain. Sultan Moulay Hassan I decided to move on the independent commercial 
centers of "Oued Noun and Tazeroualt" off the Atlantic coast in 1882 and $1886,{ }^{252}$ "fearing that other European interests would gain a foothold on the coast" (Trout 1969, 152).

These actions conspired to reduce 'control' by the Sultan of Morocco over the southernmost regions of the Western Sahara, and encouraged stronger feelings of tribal identity among Western Saharans beyond the Oued Nun, the Oued Dra'a, indeed into the Oued Sequiet el-Hamra. The actions by France, Spain and other powers brings us to the following questions. (1) Did European colonization have a crystallizing effect on Sahrawi national identity? Or (2) did the anti-colonial opposition movements have a significant effect on Sahrawi national identity? These answers are shaped by four developments: A) European commercial ventures in the region; B) the 1884-1885 Berlin Conference; C) the several treaties between the Sultan and the European powers; D) intensification in the power of tribal autonomy.

First, the colonizers pursued not only commercial ventures on the coast but also exploratory missions to the interior of the Sahara (in search of even more marketable resources and more navigable transport routes). Various geographical societies of the age sponsored these explorations. The British bypassed direct conversations with the Sultan by employing Scottish trader, Donald Mackenzie, who only consulted with Shaykh Beyruk for a 'portion' of land labeled as the 'Tarfaya Strip. ${ }^{253}$ Mackenzie then established the North-West African Company (1879) in order to extend British trade in the area. The dispute ${ }^{254}$ between Morocco and the tribes that aided Mackenzie over Cape Juby would go on for twenty years. Shortly before Sultan Hassan

\footnotetext{
252 Trout states that "as a result of these campaigns, as series of Moroccan posts were established to the south of Agadir: at Tiznit, Kasbah Ba Amrane, Assaka, and at Goulmine.” Frank E. Trout. Morocco's Saharan Frontiers, (Geneva: Librarie Droz, 1969), 152.

253 The Tarfaya Strip, or 'Tarfaya,' "called by the natives" as such, beginning with Cape Juby, was according to (Lt.Gen.) Sir Arthur Cotton, "was some 100 miles south of the Wad Draa, which is recognized as the southern boundary of the Sultan of Morocco's territory, and 50 miles north of the river Sakiet el Hamra." The Story of Cape Juby, (London: Waterlow and Sons, 1894), 21, 2. Google Play Books. Accessed September 162015.

${ }^{254}$ Cotton describes that the area agreed upon with the Shaykh Beyruk "should be remembered that it is in free and independent Tekna, occupied by the tribes constituting the Ait al Jamel, and below the Wad Draa, the southern boundary of the Sultan's dominions, that the North-West African Company has settled.” Ibid., 21.
} 
I's death in 1892, the British consented to sell "Mackenzie's trading station to the Moroccans for a sum of $£ 50,000 ”$ (Trout 1969, 154). Subsequently, in a turn of events in favor of Morocco, the first clause of the Treaty of 1895 stated, "If this [Moroccan] Government buy the buildings, etc., ...no one will have any claim to the lands that are between Wad Draa and Cape Bojador, and which are called Terfaya... and all the lands behind it, because all this belongs to the territory of Morocco" (Herstlet 1909, 970).

There are two different accounts as to the claim of the southernmost limits of Morocco (See Trout 151-152 and Rézette 59-72). Rézette argues that Spain's ambitions were not only to open ports of entry and thereby the exploration of the 'hinterland' but also "to prevent other powers, especially England from doing so" $(1975,55)$. For example, La Sociedad Española de Geografía Comercial (SGC), La Sociedad Española de Africanistas y Colonialistas (SAC), and La Sociedad Geográfica de Madrid (1876) were able to send various explorers and entrepreneurs to southern Morocco on behalf of Spain (Burke III 1972, 178-179). In an excerpt from Algueró Cuervo:

Spain, via the Canary fishermen, retained, into the nineteenth century, a presence, token if you will, but effective, on the African coast in proximity to the Canary Islands. For that reason, when in 1876 ... Mackenzie created a trading post in Cape Juby, in a zone-supposedly abandoned - vital for Spain, the indignant voices were raised of those who represented the Hispanic version of Africanism that was already prevailing in Europe ${ }^{255}(2006,49)$.

The Spanish sought to emulate British action by negotiating with the tribes of Ouled Delim. In 1884, these actions established ports of entry for trade at the Rio de Oro bay in September 1881 ("bounded by what is now the coast and peninsula of Villa Cisneros") and other trading stations in November and December of 1884 (Rézette 1975, 59). Moreover, the Spanish, not wanting to

\footnotetext{
255 Translated from the Spanish by the author: "España, a través de los Pescadores canarios, conservaba, entrado el siglo XIX, una presencia, testimonial si se quiere, pero efectiva, en la costa Africana próxima a Canarias. Por eso, cuando en 1876...Mackenzie creó una factoría comercial en Cabo Juby, en una zona — supuestamente abandonadavital para España, se alzaron las indignadas voces de quienes representaban la versión hispana de un africanismo que triunfaba ya en la Europa." José Ignacio Agueró Cuervo, El Sahara y España: Claves du una Descolonización Pendiente, (Las Palmas de Gran Canaria: Ediciones Idea, 2006), 49.
} 
get involved in the dispute over Cape Juby (given to Mackenzie by the tribes therein on behalf of the British) pushed farther south of Cape Juby.

Second, in the 1884-1885 Berlin Conference the Great Powers accorded themselves the right to take not only coastal emplacements in Africa, but also the interior lands, so long as the inhabitants acquiesced to their rule. Needless to say, these decisions were discussed without the consent of any African representatives. Spain publicly 'declared' to the competing powers (July $1885)^{256}$ that the "Spanish protectorate of the African coast" extended from Cape Blanc to Cape Bojador (Rézette, 60; Trout, 151; Agueró Cuervo, 51-52). There were numerous treaties between the Spain, France, and Britain and the Emirates in southern Western Sahara, the Sultanate of Morocco, and with Algeria.

At this juncture European fascination with northwest Africa impeded any effort to bring about greater western Saharan, much less Sahrawi, unification. Moreover, European exploration highlighted disputes over the southern delimitations of the Sultan's dominion. Trout explains it well when he writes that "at the close of the nineteenth century," when Morocco's southwestern borders were being debated: "It was impossible to give credit to Moroccan pretentions when there was no evidence of existence of any Moroccan administrative control either in Mauritania or in the Soudan [i.e., modern day Mali]. The issue that arose was instead the question of where lay the southern-most limits of the bled-es-siba" (Trout 1969, 144). The bilad as-siba, or land of dissidence, would remain an area of contested control despite the independencies present at the time. Although the Sultan laid claim to areas as far as the Senegal, at no point is there evidence that did the population acknowledged them, administratively, politically, or even culturally. In fact, as the scholarship demonstrates, the only recognition was within the context of spiritual authority. The problem was not the existence of a Moroccan Kingdom; Rather, the problem was

\footnotetext{
${ }^{256}$ However, this declaration was made on December 26, 1884 to the Great Powers and then later placed in writing on January 14, 1885. Robert Rézette, The Western Sahara and the Frontiers of Morocco (Paris: Novelles Edition Latine, 1975), 60.
} 
determining those geographical boundaries, and assessing whether the Kingdom's physical, territorial influence extended up to these ends. Written works on the socio-historical development of the northwestern Sahara has thus far not revealed far-reaching support for a (historical) 'Greater Morocco' that dominated lands beyond the Sous and Dra'a River Valleys, much less deep into the southwestern Sahara approaching the Senegal.

Third, several treaties and agreements on behalf of the European powers, diminished the Sultan's power and influence over not only the disputed territory, but also his own. These treaties began to fragment any unifying momentum from the time of the Ma' Al-'Aynayn-led rebellion. For example, the Treaty of Muni (or Paris) signed (27 June 1900) by both Spain and France established their possessions on the coast of the Sahara but did not take into account its inhabitants. According to Barbier, the treaty, "In fact, [it] only covered the southern and southeastern border of the Rio de Oro, la Seguiet el Hamra being ignored [or set aside]. Moreover, as they did not know the country very well, that border was essentially based on the meridians and parallels, without taking into account its inhabitants" (Barbier 1982, 58). Again, in 1902, further negotiations ${ }^{257}$ between France and Spain delineated "their respective spheres of influence in Morocco" (ibid., 59). Article 3 of the 1902 convention stated that,

it determined the dividing line between the French and Spanish spheres of influence. In particular, it gave Spain a zone in the north ... and another in the south, which was located between the Rio de Oro and the Oued Sous and included Seguiet al Hamra, the Tarfaya area, the Draâ, the Nun and the AntiAtlas. This showed that the Moroccan government did not exercise its authority over the region located south of the Oued Sous and neither France nor Spain recognized such authority ${ }^{258}$ [Emphasis added] (ibid.)

\footnotetext{
257 These negotiations resulted in a draft convention on November 8, 1902 but was not ratified. Maurice Barbier, Le Conflit du Sahara Occidental, (Paris: L'Harmattan, 1982), 59.

${ }^{258}$ Taken from the French and translated by Dr. Maria Antonieta Garcia: En 1902, il y eut de nouvelles négociations entre la France et l'Espagne, en vue de délimiter leurs zones d'influence respectives au Maroc. Ces négociations aboutirent à un projet de convention le 8 novembre 1902, mais qui ne fut pas ratifié. Dans son article 3, celui-ci déterminait la ligne de démarcation entre les sphères d'influence française et espagnole. En particulier, il accordait à l'Espagne une zone dans le nord, ... et une autre dans le sud, qui était située entre le Rio de Oro et l'oued Sous et comprenait la Seguiet al Hamra, la région de Tarfaya, le Draá, le Noun et l'Anti-Atlas. Cela montrait que le gouvernement marocain n'exerçait pas son autorité sur la région se trouvant au sud de l'oued Sous et que ni la France, ni l'Espagne ne reconnaissaient une telle autorité. Barbier, Le Conflit du Sahara Occidental, 59.
} 
The secret convention of 1904 in Paris and another in Madrid in 1912 also led to further European appropriation of the lands in the northwest Sahara. These conventions confirmed that (despite Morocco's claims to most of the northwest Sahara) the colonial powers did not acknowledge any Moroccan authority to the lands adjacent to its peripheral south and southeast. In 1904, a clandestine agreement between France and Spain affirmed their rights and interests in the region. "The agreement determined the sphere of influence of Spain on the Moroccan Mediterranean coast. It also fixed the boundaries of the settlement conceded by Morocco to Spain in Santa Cruz de Mar Pequeña, that is to say Ifni, under the treaty of 1860 (Article 4). Finally, it completed the Spanish Sahara border (see map 7.1 above) and delimited the sphere of influence of the French and Spanish in the south" ${ }^{259}$ (ibid., 60). In November of 1911, German ambitions in North Africa were made known at the resolution to the Second Moroccan Crisis (or Agadir Crisis of July 1911). The resolution included two letters of understanding between France and Germany. Barbier stressed what was not found in those letters, "the recognition by France and Germany of Morocco 's borders and sovereignty on the Seguiet el Hamra and Mauritania...the context clearly shows that it is not so"260 (ibid., 61).

France and Spain needed to ascertain that they were really free "to exercise their influence" within the frontiers of Morocco. However, this was not possible, because clear limits did not exist. They had to indicate the zones of influence (ibid.). The treaties "recognized Spain's freedom of action in the territories of Saguia al-Hamra and Cape Juby, 'which are outside the borders of Morocco"” (Abi-Mershed and Farrar 2014, 12). Also, Merry Del Val writes that

\footnotetext{
259 "la convention déterminait la sphère d'influence de l'Espagne sur la côte marocaine de la Méditerranée. Elle fixait aussi les limites de l'établissement concédé par le Maroc à l'Espagne à Santa Cruz de Mar Pequeña, c'est-à-dire à Ifni, en vertu du traité de 1860 (article 4). Enfin, elle complétait la frontière du Sahara espagnol, délimitait ainsi les sphère d'influence française et espagnole dans le sud." Barbier, Le Conflit du Sahara Occidental, 60.

${ }^{260}$ Taken from the French: "une reconnaissance par la France et l'Allemagne des frontières du Maroc et de sa souveraineté sur la Seguiet el Hamra et la Mauritanie: "le contexte montre clairement qu'il n'en est rien." Ibid., 61.
} 


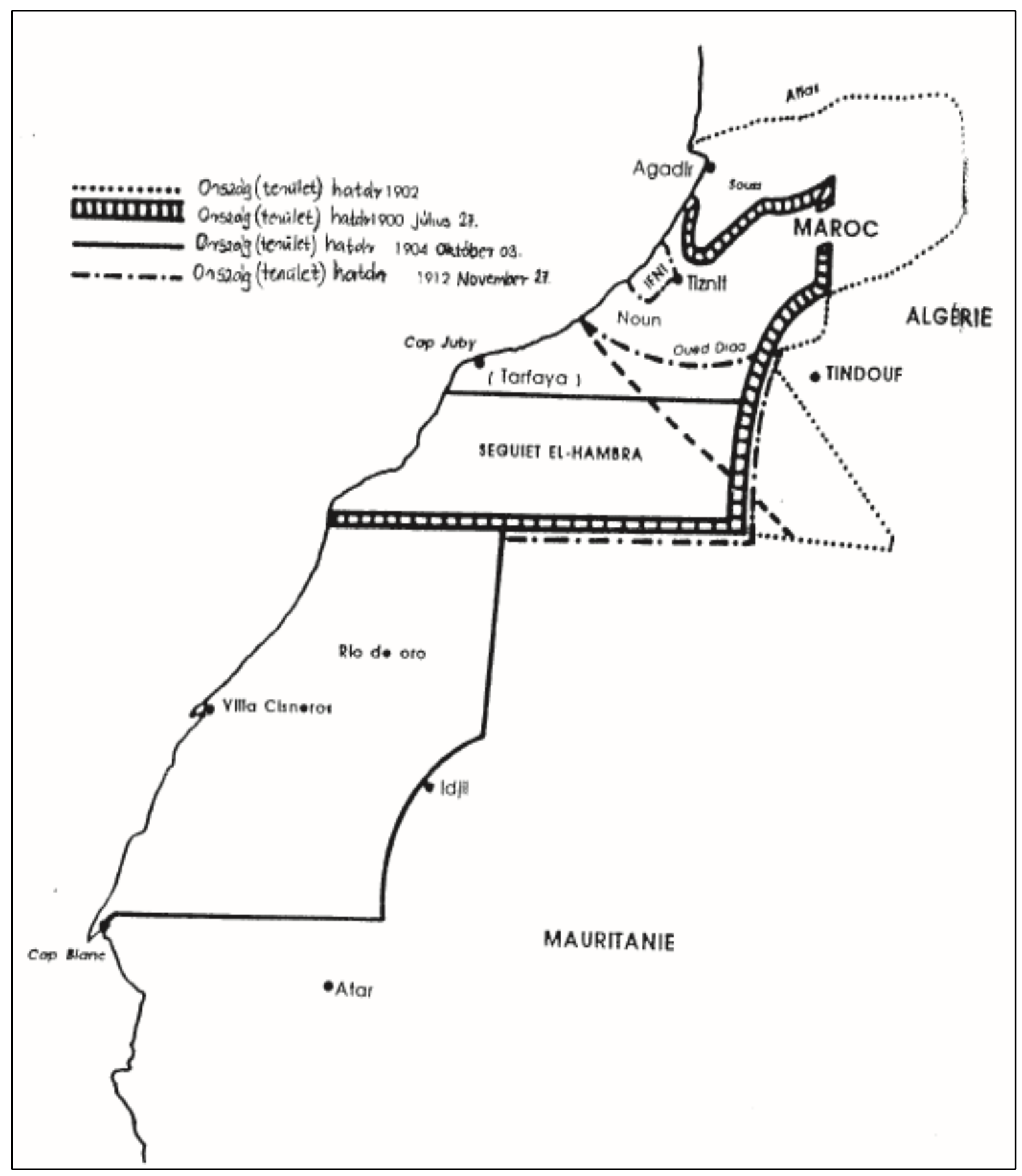

Map 7.2: 1912 Territorial Distribution of Western Sahara ${ }^{261}$

261 The above legend is written in Hungarian and translates as 'Country' (Ország), 'Territory' (Terület), and 'Limit' (Határ). Map taken from Attilio Gaudio, "Les Populations du Sahara Occidental: Histoire, Vie, et Culture," (Paris: Karthala, 1993), 48, in János Besenyő, "Western-Sahara under the Spanish Empire," AARMS (Academic and Applied Research in Military and Public Management Science) 9, No. 2 (2010), 201. 
apart from the northern zones and Sidi Ifni, "From Cape Nun southwards the Spanish zone begins once more, extending on the south to Cape Bojador, the northern limit of our colony of Rio de Oro, and on the east to meridian $11^{\circ} \mathrm{W}$. of Paris (see map 7.2 above). The famous Sakiet el Hamra marks the extreme limit of the Shereefian Empire, if indeed this realm ever extended so far" (411, 1920). By 1913, Spain began deploying troops to its northern territories. It had garnered several possessions in the Sahara and across Morocco. However, some of these, including Ifni, had still not been occupied due to financial setbacks and other military delays caused by the interruption of World War I.

As agreements indicate, the colonial powers of Europe were cognizant that there was a physical Kingdom of Morocco and that it had a prominent role in North African politics. However, it also acknowledged that the Sultan's influence or authority could not have extended beyond the disputed areas extending along the coast, in the region of Oued Nun, the Sous, Oued Dra'a, or farther south to the Sequiet el-Hamra. Based on this understanding, the Spanish, French, and British undertook bilateral diplomatic and commercial exchanges with the independent tribes. They viewed these populations as separate political entities distinct from 'Morocco.' There was even more uncertainty inland, to the south and southwest of Morocco, which was also undefined. These developments rapidly gave the independent tribes of the Western Sahara more power to maneuver and also gave them a bigger stake in the welfare of the region; in essence, an enhanced group awareness.

With the exception of the account (section below) of Ma' Al-'Aynayn's creation of a cohesive force for the purpose of throwing off the colonizers, there was still no evidence of the formation of a 'Sahrawi national identity.' In fact, these treaties and 'handshakes' among the powers of Europe only served to fragment the physical boundaries of the tribal inhabitants. The bilateral negotiating nature of Britain, France, and Spain with the tribes exploited tribal rivalries and fears. It also alarmed the Sultan. Independent tribes, cognizant of European meddling with 
fellow rival tribes, maneuvered to counter the threat. They either cooperated to gain (economic) advantages or resisted to maintain their security with the European powers to offset any disadvantages with fellow tribes. Thus, a tribal balance of power developed in the Western Sahara that pitted tribes against each other, but enhancing their group consciousness.

In short, rather than solidify a consensus of 'national' resistance, European intrusion only served to strengthen tribal rivalries, fragmenting them even more. These agreements merely dictated territorial boundaries, not the manner of governance in these possessions. Clearly what is observed from these documents and agreements is the recognition of a Kingdom and his possessions, of which still had not been defined properly. Distinctions that can be made are those of tribal rule versus dynastic rule, territorial domains of the Sultan and those that were not, and perhaps a sentiment of opposition against both the Sultan and Europeans. Did these agreements influence the identity of the populations that were not under the rule of the Sultan? They did not. They merely acknowledged that the populations south of the Kingdom were governed by other independent chiefs. These independent confederations of tribes had established tribal identities but had not begun to coalesce into a distinctive Western Saharan collectivity. A Sahrawi national identity is still not apparent. Below, the fourth development of the period is analyzed.

\section{Tribal Distinctiveness}

Fourth, competing tribal identities was historically the underlying, fundamental obstacle to an entire Saharan 'collective.' By now, an interesting identity paradox vis-à-vis Moroccan identity had developed. On the one hand, a distinct Saharan culture, divided amongst the several nomadic and semi-nomadic tribes across the northwestern and southwestern Sahara, had been established. These claims have been evident in this work and cited by several other Saharan scholars. They exist in yet-to-be studied manuscripts of the greater Western Sahara. The point here is that this scholarship highlights the historical, linguistic, and socio-cultural differences between the 
Saharan tribal nomad/semi-nomad and the sedentary, urban Moroccan. These distinctions are extremely subtle. If one were to speak to the 'Sahrawi,' they adamantly differentiate themselves from their northern neighbors and explicitly re-state how the foods, dress, role of women, and even the practice of Islam is different from that of a Moroccan.

In keeping with this point, the foods, as experienced while visiting the area, were somewhat different. These differences reflect an influence by Spanish colonization. At least once a day, meals included a Spanish paella, which was then customized to Sahrawi tastes. In terms of dress, there is the daraa robe ${ }^{262}$ worn by men, in contrast to the djellaba worn by both men and women in Morocco and Algeria. Sahrawi adult women wear a different outfit that includes a head covering, called the malahfa ${ }^{263}$ (or melhfa). In Morocco, the women wear the hijab or niqab, sometimes with the djellaba. Islam, as the writer was told, also has very subtle differences due to the urban-nomadic environments. Most of the Arab world, before daily prayers, will complete ablution with water. Throughout the centuries, the Muslims of the Sahara, due to water scarcity, have used sand to mimic the cleansing before praying. Perhaps the biggest difference of all is language. The Sahrawi speak the Arabic dialect of Hassaniya ${ }^{264}$ (see map 7.3 below) while most Moroccans speak Derija (Moroccan dialect). Both are not spoken anywhere else in the Arab world except in their respective regions and they exist mostly in oral form. The two versions are

\footnotetext{
${ }^{262}$ The Daraa robe a loose gown with two openings on the sides and a pocket on the breast. The gown is usually either white or blue. "daraa," Cultural Website of the Sahara, accessed on January 14, 2016, CORCAS 2016, http://www.sahara-culture.com/Default.aspx?tabid=416.

${ }^{263}$ This is a four-meter long by one meter and sixty-centimeter-wide piece of fabric/cloth worn by the Sahraoui woman wherever she goes. "Al malahfa," Cultural Website of the Sahara, accessed on January 14, 2016, CORCAS 2016, accessed on January 14, 2016, http://www.sahara-culture.com/Default.aspx?tabid=416. "The Melhfa is a tradition that is found in Sahrawi culture far back in time. The Melhfa is one of the cultural traditions that make the Sahrawi nation distinctive from other peoples." Silje Rivelsrud, "The Sahrawi Refugees and their National Identity: A Qualitative Study of How the Sahrawi Refugees Present their National Identity in Online Blogs," MA Thesis, Universitete I Olso, May 2010, 52.

${ }^{264}$ Hassaniya became the dominant language among Saharans in the seventeenth century. Today, it is the national language of Mauritania, spoken mostly in oral form.
} 


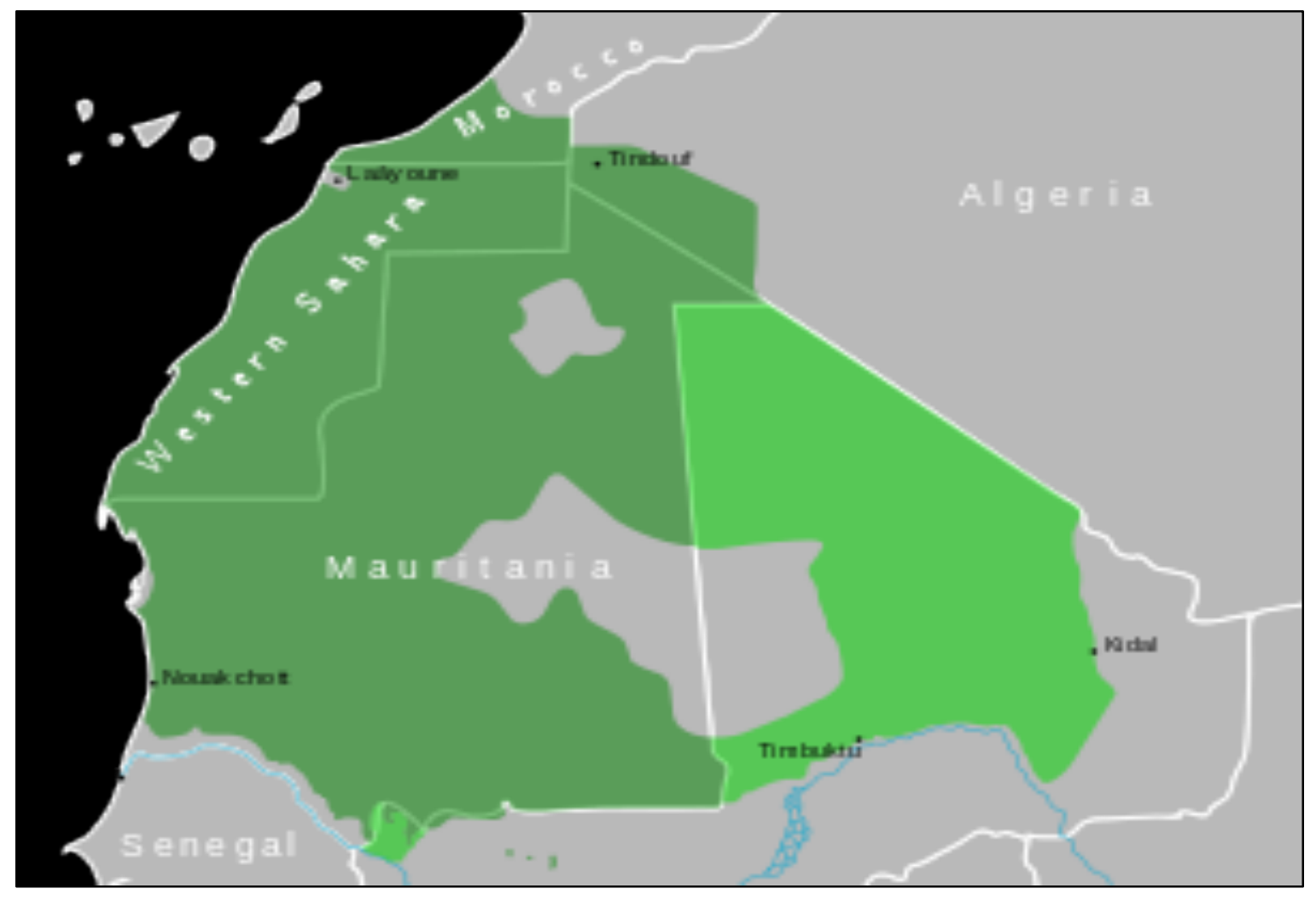

Map 7.3: Location of Majority Hassaniya Speakers ${ }^{265}$

not entirely mutually unintelligible but differences exist in phonology and syntax. Although some scholars describe each dialect as a different language altogether.

One of the more surprising differences with respect to language was the adoption of Spanish. Many educated Sahrawi today speak Spanish, which is directly tied to the influence of Spanish colonization. The author found himself pleasantly surprised when many of the POLISARIO interviewed spoke Spanish. However, in the interviews, none made reference to this feature as part of their identity. During the author's stay in Morocco while a Peace Corps Volunteer and a diplomatic intern in Rabat, the language of choice was French. ${ }^{266}$ Even while training as a volunteer in Immouzer-Tandar, Morocco, a predominantly Berber-speaking

265 "Hassaniya Arabic," Mediander.com, New York, 2016, accessed August 14, 2016, http://www.mediander.com/connects/558481/hassaniya-arabic/\#!/p3/topic/-/.

${ }^{266}$ The author was more comfortable with French than with Moroccan Arabic. 
(Tamazight) city, most of the educated spoke in French. It was peculiar to find that the people did not identify with these colonial languages as being part of their respective national identities. However, despite their dislike of colonialism, both populations use these languages as tools for advancement, education, and activism ${ }^{267}$ (as in the case of the Sahrawi).

These apparent, cultural markers seem to differentiate Saharan and Moroccan identity. On the other hand, the second point in this paradox has been described sufficiently in the previous chapters. Despite claims of distinctiveness from Morocco, far from being of one mind, or of one cohesive national identity, the Saharans in this 'land of the Moors' "never experienced political unity" (Hodges 1983a, 30) . As mentioned in previous chapters, Saharan society "was made up of a number of autonomous, often conflicting emirates, confederations and tribes" (ibid., 30-31). The northwestern, western, and even peripheral southwestern Saharan emirates, confederations of tribes and sub-tribes traded and intermarried with each other. Nonetheless, they also commonly warred with one another, creating deep blood feuds that carried over for hundreds of years. The violence could include conflict over cattle, land, trade routes, and personal vendettas. In summary, the overall theme seems to be of a certain separateness from others based on important socio-cultural characteristics evident to the native Saharan.

Hodges argues that a Western Saharan's prime loyalties in the twentieth century were first to "tribe (qabila), tribal fraction (fakhd), and family" (Hodges 1983a, 29). This loyalty, to a qabila and below, remained the perennial force behind Saharan society. There was also a certain caste system among and within tribes - free or shurfa tribes, then znaga ${ }^{268}$ (subordinated) or lahma), third, the bards and craftsmen, and finally the slaves and ex-slaves (haratin) (ibid., 29).

\footnotetext{
${ }^{267}$ Curiously, of the major countries colonized by France, only Algeria, Mauritania, and Mali recognize the SADR, mainly for regional security reasons. While the SADR is currently supported by nearly half (9) of all Latin American (Spanish-speaking) countries (19). Costa Rica, Colombia, and Paraguay at one point recognized the SADR (pushing the total to 12) but diplomatic relations today remain 'frozen' or 'suspended.'

${ }^{268}$ This label is not to be confused with the actual ancient name of the Sanhaja Zenaga subtribe. However, this label has been credited by scholars as being derived from the defeat of the Zenaga at the hands of the Arab Beni Hassan tribes in the Char Bubba Wars.
} 
These "notions of blood loyalty (asabiya)" were very strong before, during, and after the 'pacification' (1934) of most of the Western Sahara by French and Spanish forces. The distinguishing features alluded to by Hodges include the following: Hassaniya dialect of Saharan Arabic, "an economy based on pastoral nomadism and commerce, the frequent practice of raiding;" dress; diet; poetry; and Islamic practice (ibid., 30). These tribal features though stretched beyond modern Western Sahara. In other words, these distinctions were part of the greater expanse of the northwestern Saharan. Still, these cultural markers apparently had not yet created a sense of a regional identity.

Since such divisions were present among many tribes in the Western Sahara, it would have been very difficult for any ruler to bring these groups together for any type of cooperative action. For example, the Sultan had sent delegations to many tribes in the region with the hope of 're-establishing' Moroccan administration. However, these attempts to gain recognition for the authority of the Sultanate were thwarted or ignored. According to Hodges, the much bigger tribes led by "the emirs of Trarza, Adrar, Tagant, and Brakna" were unwilling "to recognize [the Sultan's] authority" (Hodges 1983b, 35). Neither the larger, better established (and more sedentary) Saharan communities, "[n]or...the Reguibat; and even the main nomadic Tekna tribes to the south of the Noun, the Izarguien, Ait Lahsen and Yagout" ... submitted to the Sultan (Hodges 1983b, 35). Even when the Sultan or another leader, such as Beyruk controlled parts of an area, such power was temporary or nominal. "In 1899," for instance, "a force of Moroccan and Ait Moussa Ou Ali soldiers, sent from Goulimine by Dahman Ould Beyrouk to chastise the Izarguien, was routed at Daora..., and when the Ait Oussa, a partly nomadic Tekna tribe centered on the oasis of Assa in the Djebel Bani, joined the Reguibat in sacking Tindouf in 1895, nothing was done, by either the [S]ultan or Dahman, to aid the Tadjakant or prevent the Ait Oussa from aiding the Reguibat" (36). Thus, the area to the southwest of the Sultanate of Morocco was not controlled by the Sultan, but neither was the population unified as a social group. 
These differences became a bit more complicated when direct European meddling into the interior of the Sahara began at the beginning of the nineteenth century. At this juncture appears the most common and perhaps only thread of unity among the Saharan tribes and the Moroccan population: an aversion to European Christian encroachment on 'Islamic lands.' Their relationship with foreigners had been, since the beginning of early European colonization (14001500s), very reserved to hostile. At specific points in time, if the terms for commerce with the Christians were advantageous to a tribe or Sultan, hostilities would cease for the purposes of trading (until grievances by competitors forced an end to trading or the foreign trading partner was banished from the area). By the 1800 s, a time of direct European involvement in the affairs of Morocco and the rest of the northwestern Sahara, the first widespread countermoves against the French were evident in West Africa among the ancient, southern Saharan Emirates bordering the Senegal River Valley. The (Moroccan) Sultan also lobbied against European intrusion and positioned his military alongside its 'domains' from Spanish, British and French settlements. In general, the inhabitants of the greater northwestern Sahara, including the lands throughout Morocco, southwest into modern Mauritania, and as far south to the ancient Emirates, approved of were united in their rebellious behavior toward European, Christian invaders.

Nevertheless, these distinctions were not sufficient to unite the tribes or create a regional national identity across the whole Morocco/Western Sahara territory. The Spanish explorer, Enrique d'Almonte spoke of the mistrust between Moroccan and Saharan guides and translators employed by foreign adventurers. In 1926, Antonio Jaén, a Spanish colonizer,

yet again insisted that the frontier between Morocco and the Sahara was 'formed by the river Draa,' and six years later, José Guillermo Sánchez clarified that 'although [the Sahara tribes] respect the Sultan of Morocco, they do it because he is a descendant of the Prophet, not because they have any intention of becoming his subjects'; as all the Africanist writings of these decades illustrate, the tribes of the Spanish Saharan dominions have always 'live[d] with a savage independence, [and] without a supreme chief' (San Martín 2010, 25). 
At the same time that the major European powers discussed the partition of Africa, they slowly engaged in a game of territorial gain through diplomatic, and eventually, coercive attrition with the Sultanate and the rest of northwest Africa. In light of this threat, the Sultan and finally, Ma' al-'Aynayn, who is discussed below, "swore to uphold the laws of the sultan in the Western Sahara and Mauritania, and in 1895, his warriors seized Port Victoria" (Abi-Mershed and Farrar 2014, 12). However, Morocco acquiesced to the Great Powers of Europe despite the 'rebellion' in secret dealings and treaties negotiated in 1904, with the Sultan in $1906^{269}$, and the Treaty of Fes in 1912. Nonetheless, territorial reality did not conform to the words written in these documents. "Spain obtained the territory of La Hamada and the border was fixed at parallel $27^{\circ} 40^{\prime}$, but the territory up to the Draa was left with the uncertain name of Spanish 'zone of influence,' because the Tekna ${ }^{270}$ nation remained without a clear definition of how the word 'influence' should be interpreted"271 (Canales Torres and Del Rey Vincente 2010, 37). The underlying bond was not a unification of (Western) 'Saharans' but a campaign to dislodge the Christian infidels from the lands of Islam and implement the authority (at least in name) of the Sultan. Yet again, there is no definitive awakening of a 'Sahrawi' national identity. In short, the people of the region did not have a common political identity, but they did reject the political control of either the Moroccan Sultan or of European colonialists.

\footnotetext{
269 The First Moroccan Crisis $(1905$ - 1906) resulted in the 1906 Algeciras Conference where Sultan Abdelaziz ratified the Act of Algeciras. The Act reaffirmed his independence "and the economic equality of the" European powers, but it included a program of police 'reforms' that provided "French and Spanish police officers be under a Swiss inspector general." Encyclopedia Britannica, s.v., “Algeciras Conference," Online Edition 2016, accessed August 15, 2016, https://www.britannica.com/event/Algeciras-Conference .

270 "Finally in the accords for the establishment of the Hispano-French Protectorate over Morocco, signed 27 November 1912, the Tekna 'nation' became the so-called 'Protectorate South' finally granting the territory north of $27^{\circ} 40$ a definitive legal status." Carlos Canales Torres and Miguel del Rey Vicente, eds., Breve Historia de la Guerra de Ifni-Sáhara, (Madrid: Ediciones Nowtilus, 2010), 37.

${ }^{271}$ Taken from the Spanish and translated by the author: España obtenía el territorio de La Hamada y se fijaba la frontera en el paralelo $27^{\circ} 40^{\prime}$ ', pero dejaba con el inseguro nombre de 'zona de influencia' Española el territorio hasta el Draa, por lo que el país Tekna quedaba sin que se definiese con claridad cómo se debía de interpretar la palabra influencia. Ibid.
} 


\section{Ma’ Al-‘Aynayn}

Both parties to the conflict (the POLISARIO and the Kingdom of Morocco) have adopted Shaykh Ma' al-'Aynayn and his actions as part of the claims to the Western Sahara. The POLISARIO have described his exploits as representations of the aspirations of all Western Saharans in terms of 'liberating' these 'occupied territories' from foreign intruders and as a symbol of the development of the Sahrawi 'nation.' In contrast, Morocco argues he is an important part of their national history. The case for either is compelling. Al-'Aynayn (1830-1910) stands out as one of the more remarkable events and personalities in the long-running dispute over the Western Sahara. His actions will be evaluated because he was the first figure in documented 'Western Saharan' history since Nasr al-Din to unite several of the region's tribes. ${ }^{272}$ Al-'Aynayn's exploits, adopted by the Sahrawi as part of their history, led to the formation of a more formal Western Saharan identity.

Ma' al-'Aynayn was born into the Sufi Fadiliyya tariqa (order) as the twelfth son of Muhammad Fadil bin Mamin al-Kalkami who founded the order. His father, family, and his son claimed Sharifian descent and "lineal relationship to the Lamtuna who were the aristocracy of the Almoravid Sanhaja" Dynasty (Norris 1954, 889). In terms of national origins, al-“Aynayn and his family, are thus direct descendants of the Sanhaja Berbers and therefore ancestors to the Sahrawi. Ma' Al-Aynayn had made the Hajj (1857), settled in Tindouf to study (1860), and lived the nomadic life between the Adrar and the Oued Dra'a thereafter. He moved north to the Sequiet el-Hamra (1873) but after an unhappy decade, left the region, travelling between the Adrar and Tiris region (Désire-Vuillemin 1958, 33). In 1898, with the blessing and financial support of Moulay Abdelaziz, Al-'Aynayn built the city of Smara, located in Western Sahara. According to Miské, "Moulay Abdel Aziz was particularly sensitive to the preaching of the great Sahrawi saint.

${ }^{272}$ Al-'Aynayn is sometimes spelled El-'Aynayn, Al-Ainin, El-Ainin, or Al-Ainine. Ma' Al-'Aynayn is actually a nickname whose real name is Sidi al-Mustafa Wuld Muhammad Fadil. Glen W. McLaughlin, s.v., "Ma' al-"Aynayn," in Kevin Shillington, ed., Encyclopedia of African History Volume 1 A-G, (New York: Fitzroy Dearborn and Taylor and Francis), 2005, 869-870. 
He even sent an emissary, ... wearing an expression of solidarity with the Moorish resistance"273 $(1978,96)$.

He had gained a saintly reputation from among the Saharan population including "all the Saharan tribes of the great nomads: Regheibat, Lgouassem, Oulad Delim, [revered] him, and he [could] count on the support of the majority of the warriors of Adrar" (Désire-Vuillemin 1958, 39). He was also admired for his pilgrimages to Mecca, charismatic demeanor, and 'miracles, which quickly gained followers to the Fadiliyya order. However, Ma' Al-'Aynayn grew increasingly troubled and angered at the French and Spanish intrusion of Saharan lands. By 1904, he declared a fatwa against the foreigners and thrust his weight against the colonizers with direct support, which he embraced, from the Sultan of Morocco. He had already amassed considerable support from several Saharan tribes throughout his many nomadic journeys in Mauritania, the Western Sahara, and Morocco. Al-'Aynayn was mostly concerned with "the colonial ambitions of the French that really roused [his] fury.

Cloistered in Villa Cisneros, the Spanish were not very troublesome; but France had already conquered Algeria, Tunisia and by 1903 both Trarza and Brakna had fallen to Coppolani $^{274, "}$ (Hodges 1983b, 57). He was supported militarily by the Sultan, Spain, and Germany (rival to the French for the colonization of northwest Africa), but died in 1910 before he could complete the purging of Westerners from Saharan territory. Ahmed al-Hiba, Al-'Aynayn's son, mounted a campaign against the French when Morocco agreed to the treaty of Fes (1910) under which the Sultan, Abd al-Hafid, surrendered sovereignty to France. Thereafter, al-Hiba,

\footnotetext{
${ }^{273}$ Taken from the French and translated by Dr. Maria Antonieta Gracia: “...Moulay Abdel Aziz fut particulièrement sensible à la prédication du grand saint sahraoui. Il alla jusqu'à envoyer un émissaire, ... porter l'expression de sa solidarité à la résistance maure.” Ahmed Baba Miské, Front POLISARIO: L'Ame d'un Peuple, 197896.

${ }^{274}$ Xavier Coppolani (1830-1905) was a French colonial leader known as the father of French Mauritania, who was responsible for French control of southern Mauritania. Oxford Reference Online, s.v., "Xavier Coppolani," Oxford Index, Oxford University Press, 2016, accessed August 15, 2016, http://www.oxfordreference.com/view/10.1093/oi/authority.20110803095638514\#.
} 
'the Blue Sultan,' marched to Marrakesh (1912) and removed the "Sultan of France" for his betrayal (Miské 1978, 96). Despite this short triumph, the French army defeated him at the Battle of Sidi Bou Othman on 6 September 1912. In summary, as D’Almonte commented, “the Moorish forces that acted under the inspiration of Sidi Ma' al-'Aynayn included all the tribes of Western Sahara who traverse the territories to the north of the parallel that passes by Cabo Blanco. To these collection of tribes were added the nomads of the Adrar-er-Tmar, a part of the sedentary people of that region and a certain number of Zenagas Moors of the [T]rarza fraction"275 (D’Almonte 1914,164-165).

Today, Morocco has declared Al-'Aynayn a patriot for its Kingdom, while the POLISARIO have also claimed him as a hero to the Sahrawi, placing him in Sahrawi folklore literature. Supporters that claim him for the Sahrawi argue that Ma' Al-'Aynayn was not from Morocco proper. San Martín writes that Ma’ Al-'Aynayn was born in the Hodh (or Hawd) area, which is now part of southeastern Mauritania $(2010,31)$ and D'Almonte stated that "he established his residence in Chinguetti, an important population of the mentioned Adrar"276 (1914, 157). Mundy suggests that "the Shaykh might have been planning on deposing the then colonially complicit "Alawis to place himself on the throne" (Mundy 2007, 311). It is unclear, though, what his political program was to be after installing himself as Sultan. He was primarily concerned with ridding the northwestern Saharan lands of the French invaders and had even declared, while on a pilgrimage to Mecca, that "his people knew neither rulers nor money" (ibid., 311). Yet, Moroccan arguments state that he was loyal to the Sultan and argue that he accepted

\footnotetext{
${ }^{275}$ Taken from the Spanish and translated by the author: "las fuerzas mora que obraban bajo la inspiración de Sid Mael-Ainin comprendían todas las tribus de Sáahara [sic] occidental que recorren los territorios comprendidos al Norte del paralelo que pasa por el cabo Blanco. A ese complejo de tribus se agregaron los nómadas del Adrar-et-Tmar, parte de la gente sedentaria del mismo y cierto número de moros zenagas de la fracción [T]rarza." Enrique D'Almonte, Ensayo de una Breve Descripción del Sáhara Español, (Madrid: Patronato de Huérfanos de Intendencia e Intervención Militares), 1914, 164-165.

${ }^{276}$ Taken from the Spanish and translated by the author: "instauró su residencia en Xingueti, población importante del mencionado Adrar.” D’Almonte, Ensayo de una Breve Descripción del Sáhara Español, 157.
} 
the title of khalif of the Sahara on behalf of the Sultan in his quest to oust the French from Saharan lands.

After the rebellion of Ma' al-'Aynayn, Sahrawi 'national' sentiment became evident in limited circumstances. However, post al-Aynayn sentiments have been irregular, unsupported by the whole of the population, and vaguely viewed as 'Sahrawi' rebellions. For instance, after al'Aynayn's death, "sporadically, for 30 years, from 1904 to 1934, long-range raiding parties would set forth from 'Spanish' territory to attack the French" (Hodges 1984c, 81). Meanwhile ElHiba fought the French from the Anti-Atlas until his death in 1919. "His brother, Mohammed Laghdaf, and other Sahrawi resistance leaders, such as Mohammed el-Mamoun and El-Aissawi et-Tibari, continued raiding against the French in the desert. However, in 1934, French forces from Morocco, Algeria and French West Africa finally 'pacified' the border regions of the northwestern Sahara in a coordinated military campaign." (Hodges 1984c, 81). By then, the Spanish had already deployed troops, set up and established administrative districts, and included many of the tribal associations into their presidios. In 1946, "a decree created the Spanish West Africa administration to comprise Ifni, Tarfaya, and Spanish Southern Morocco, together with Seguia elHamra and the Rio de Oro" (Jensen 2005, 12). Yet in 1958, Francisco Franco ceded Tarfaya and Spanish Southern Morocco to the Kingdom of Morocco.

\section{The ‘Sahrawi' Dawn}

It was not until the rise of militant Moroccan nationalism after 1953 that many of the Western Saharans joined the Moroccan Liberation Army (MLA) to fight alongside Moroccan troops against Spanish and French control. According to Hodges, "thousands of Sahrawis became part of a broad, trans-frontier anti-colonial struggle only as recently as $1957-8$, when they responded to the insurrectionary appeals of the Moroccan Army of Liberation (Jaich at-Tahrir)" (Hodges1983a, 30-31). These San Martín explains that it was at the insistence of some tribal elders "based in the 
Spanish Sahara" that congratulated the Sultan on his return from exile in 1955 and the independence of Morocco. They then asked for his assistance to liberate "the Sahara from colonialism, but stressed that they would not wish to offer 'in exchange the compromise of loyalty to the King of Morocco"' (San Martín 2010, 67). The statement read with respect to the Spanish: "although it occupies a part of our land, we so not wish to make war against it, because it did not enter by means of force or arms, but through an agreement with the Assembly of the Ait Arbain [Assembly of Forty]. Therefore, what we want now is the French to leave; after that, we will not have any problem in achieving an accord with the Spanish" (Briones et. al., 2010, 67).

The key point here is that apparently, an assembly of, or in this case, a group of leaders and former Army of Liberation fighters from different tribes had been brought together to promote the cause of decolonization in the Spanish Sahara. They explicitly stated to the Sultan that they did not want to be incorporated into Morocco upon independence and they would deal with the Spanish themselves. Did they, however, consider themselves Sahrawi or as a cooperative group of tribes seeking one goal? The answer may still not be evident because more documentation is needed to evaluate this event. ${ }^{277}$ They obviously did believe that a cohesive front was necessary. They acted in unison but did not readily incorporate themselves as a 'Sahrawi' nation.

Many scholars though, such as Hodges, Mercer, Mundy, San Martín, Canales and del Rey, who write about this period already make use of 'Sahrawi' (or Saharaui) as a national marker of identity. These comments are premature. For instance, Hodges narrates a story of a rebellion that seems at first glance to suggest a cohesive network of 'Sahrawi' guerilla fighters. However, the narration actually involves certain tribes of the Reguibat, Tekna, Lebouihat (subtribe of the Reguibat), Ait Bu Amaran of Ifni, and other 'nomads' who did not have a

277 The author was only able to find one reference to this event and that brief comment was quoted in a secondary source. Primary source: Felipe Briones, Mohamed Limam Mohamed Ali, and Mahayub Salek. "Luali: 'Ahora o Nunca, La Libertad'," (Alicante: Universidad de Alicante, 1997), 38-39. Quoted in San Martín, Pablo. Western Sahara: Refugee Nation. Cardiff: University of Wales Press, 2010. 
common sense of identity (Hodges, 1983, 73-83). It is not possible to take individual tribes and suggest that these select few had considered themselves as a whole 'Sahrawi' nation. It was also unknown what were the tribe's (those who sought the assistance of the Sultan) future plans for the territory after the possible ouster of the French. How were they to govern the region agreeably with the Spanish? In another study about Moroccan identity, these group of rebels actually continued fighting "for the complete liberation of what they deemed Moroccan territory, particularly the ill-defined Saharan regions in the south that were still under French and Spanish control...renaming themselves the Army for the Liberation of the Sahara" (Wyrtzek 2015, 279). Nevertheless, the King ${ }^{278}$ of Morocco later disowned the Spanish Saharan rebels. Divisions arose. Subsequently the combined military efforts of the Spanish and French in Operation Ecouvillon and Ouragan, eliminated all resistance in 1958.

In view of the escalating problems in these colonial possessions, the UN began to deliberate on procedures for holding a referendum for the "indigenous population" in $1966^{279}$ (UNGA 1966, 4). Despite these statements, a flurry of Western Saharan groups emerged in the late 1960s to challenge colonial (Spanish) control. Some were created to promote unification with Morocco; others sought independence from Spain for the Spanish Sahara. In 1967, a group supported by and based in Morocco called the Front de Libération du Sahara sous Domination Espagnole (FLSDE), ${ }^{280}$ was created but was largely inactive and swiftly disappeared when the King opened diplomatic relations with Mauritania (Hodges 1983a, 39). At the same time, a pro-

\footnotetext{
278 The Sultan became the King of Morocco shortly after he returned from exile and promised a constitutional monarchy in 1956. C. R. Pennell, Morocco since 1830: A History, (New York: New York University Press, 2000$), 299$.

279 The UN General Assembly passed Resolution 2229, which requested Spain, "to determine at the earliest possible date, in conformity with the aspirations of the indigenous people of Spanish Sahara and in consultation with the Governments of Mauritania and Morocco and any other interested party, the procedures for the holding of a referendum under United Nations auspices with a view to enabling the indigenous population of the Territory to exercise freely its right to self-determination,' UN General Assembly, Question of Ifni and Spanish Sahara, 20 December 1966, A/RES/2229, accessed August 16, 2016, http://www.refworld.org/docid/3b00fld91c.html .

${ }^{280}$ In Spanish as 'Frente de Liberación del Sahara bajo Dominación Española' (FLSDE).
} 
independence group named the Harakat Tahrir Saguia al-Hamra wa Oued ad-Dahab ${ }^{281}$ (Liberation Movement of the Sequiet al-Hamra and Rio de Oro), began to organize peacefully, and in secret, but revealed themselves during a demonstration in the city square of el-Ayoun (Layounne) in 1970 that went horribly wrong. The rebellion was put down violently by Spanish forces. Their leader was captured and was never seen again. The group was subsequently eliminated (Besenyo 2009, 65; Mundy 2007, 313-314; Hodges 1983b, 154-155). The years of 1972-73 brought opposing resistance movements that divided the Western Sahara population and also merited support from opposing political forces. For instance, the Mouvement de Résistance "Les Hommes Bleus" (MOREHOB) ${ }^{282}$ developed in Morocco, but its leader switched sides at least twice. This phenomenon was not unique to the disparate groups that proliferated at that time. Not only was MOREHOB split between supporters of unification with Morocco and those who desired independence, but there were other groups (Mouvement of Aout 21; PUNS) vying for the hearts of the Spanish Sahara (Zunes and Mundy 2010, 103). Finally, in May 1973, the POLISARIO appeared (Jensen, 15; Mercer 1976, 504). According to Mercer, this was the "first effective grouping of the nomads" whose purpose was to liberate the lands of the Spanish Sahara against foreign domination (ibid., 504). Mercer explains that "[t]his liberation movement...had gradually absorbed the able-bodied men of all tribes except the pro-Morocco Tekna in the north and the pro-Mauritania Delim and Barik Allah in the south.” [emphasis included] (ibid.).

\section{SUMMARY REMARKS}

Based on the research into the limited literature on the subject of Sahrawi identity, the author finds that in the period beginning in 1913 through 1973, Western Saharan national identity began

\footnotetext{
${ }^{281}$ Juan Goytisolo calls this group 'Munaddamat Muslim' (Muslim Party or Organization) in El Problema del Sahara, (Barcelona: Editorial Anagrama, 1979), 37 and 39. Also in "Cronología de una Descolonización," Blanco y Negro, 07 September 1977, (Madrid: Diario ABC, 2009), 24, accessed August 16, 2016, http:/hemeroteca.abc.es/nav/Navigate.exe/hemeroteca/madrid/blanco.y.negro/1977/09/07/024.html .

${ }^{282}$ MOREHOB was created in 1972 by an ex-policeman, Bachir Figuigui also known as Eduardo Moha.
} 
to coalesce without the use of a 'national' label. Instead of developing a general sense of 'nation awareness' especially in this sixty-year period, the 'greater' Western Sahara was regionally divided among its inhabitants. Independent political entities flourished and established governments, set rules of engagement against others, and had distinctive avenues of trade. The Sultan of Morocco, by deploying messages and messengers to the rulers of these political communities, was tacitly acknowledging their autonomy and authority as the leaders of their respective populations. Furthermore, it is evident that the emirs of those areas would at times recognize the Sultan's spiritual authority but only out of respect, for the benefit of their population (trade, military gain). The development of tribal loyalty and an accompanying tribal or confederated tribal identity was evident. They preferred a community of tribes such as the Reguibayt, Tekna, Oulad Delim or even Kunta but not identified as 'Sahrawi.'

Just as the Sultan attempted to extend his influence over Sahrawi tribes at the beginning of the twentieth century, the Europeans landed in the area and began to conspire against the Sultan's ambitions. They enacted treaties amongst themselves, with the Sultan, against the Sultan, or simply without consulting the Sultan. The inhabitants of the greater Western Sahara were completely irrelevant. All powerholders assumed their passive cooperation. For the most part, these agreements did recognize the Sultan's authority, more or less, in Morocco proper. They also held that south of the Sous, Oued Dra'a, and farther south in the Sequiet al-Hamra River Valleys, his dominion was questionable. The Sultan's influence was observable in urban socio-political environments.

Farther south among the frontier nomads, especially those of the deep Sahara Desert, allegiances to clan, tribe, and then tribal confederations abounded. There was no sense of loyalty to the entire population of Spanish Sahara. In addition, the nature of Saharan subsistence differed from those sedentary dwellings closer to the coast, in the more populated cities, and in the Atlas Mountains. Patterns of subsistence developed differently in more populated areas from those in 
inhospitable rocky hamadas and dune landscapes. Still, the distinguishing socio-cultural markers: the loyalties to the immediate tribal 'family,' the appearance of independent political entities, and the encroachment of foreigners all combined to keep the Saharans from cultivating a cohesive national identity, that which is considered nationhood.

The notion of any 'Saharan' identity became an underlying theme when it encountered aggressive foreign intrusion, especially from the French. The French took advantage of the European agreements at that time and made their way southwest from Algeria and northeast from the Senegal River Valley into Morocco and the Greater Saharan desert. This 'Saharan Awakening' was short-lived. Subsequent rebellions were eliminated until the emergence of the Moroccan independence movement. This movement gave new life to a segment of the Saharan population, but leaders who were either supported or based in Morocco guided the group. After the departure of the Spanish, the movement changed its political focus to eliminate the remaining 'colonizers'-Morocco and Mauritania. Therefore, the rise of anti-colonialism, created by grievances against France and Morocco at the critical stages of Moroccan independence, allowed for the establishment of the POLISARIO, which in turn, took hold of the effort and appropriated the cause.

Perhaps the only indigenous Saharan movement that may be considered the precursor to the current Sahrawi independence movement was the Harakat Tahrir Saguia al-Hamra wa Oued ad-Dahab. The remnants of this group would later form the POLISARIO FRONT. In a formal declaration, the FRONT claimed it was "a 'unique expression of the masses, opting for revolutionary violence and the armed struggle as the means by which the Saharawi Arab African people can recover total liberty and foil the maneuvers of Spanish colonialism"' (Mundy 2007, 317). Another statement, named the 'Guelta Zemmour declaration' followed (November 28, 1975). It was signed by several "indigenous leaders, shuyukhs, and notables," and it claimed that the POLSARIO Front was "the only legitimate representative of the Sahrawi people" (ibid.). 
Was this the moment when a real national identity for the inhabitants of the former Spanish Sahara forged? Do written proclamations by ambitious leaders constitute the formation of real national groups? Even the term 'Sahrawi' ${ }^{283}$ has brought additional confusion. Is it an adjectival description of Sahara, ${ }^{284}$ or a cultural marker of symbolic resistance? The author of this work agrees with Mundy when he examines the ambiguity of the origin of the word and responds that the "aim is not to deprive Western Sahara nationalism of it dignity, but rather to understand it more fully" (ibid., 319). However, national identity cannot be tied directly to written concepts or terminology. Rather, identity has to be viewed in a more holistic manner. National identity includes common historical experiences, including colonialism; a common culture-language, perhaps in this case the practice of Islam, dress, food; and the realization by the people that there is a legitimate enterprise that seeks well-being on their behalf through independence.

Western Saharan ethno-cultural layers (primordial arguments) of identity developed over time. They formed the building blocks of their identity. These, combined with the developments of colonialism (constructivist arguments) and leaders of resistance (instrumentalist arguments), produced a greater Western Saharan group consciousness in this period. By the time Moroccan nationalists began their pursuit for independence, support for a Western Saharan national identity was ripe. The critical juncture at which the Sahrawi together made the giant leap toward 'national identification' resides during this period and culminated in concrete form with the POLISARIO.

\footnotetext{
${ }^{283}$ Mundy, Zunes, Castellino and Dominguez-Redondo comment that the meaning for the term 'Sahrawi' may have had different connotations during the 1950s and well after Moroccan independence in 1956. As Castellino and Dominguez-Redondo state: "Before colonization, it was not possible to speak about the 'national identity' of the Sahrawi people. The term 'Sahrawi' derives from the Spanish Sahara and would have not existed before the midtwentieth century. Meaning 'Saharan' in Arabic, the term Sahrawi has a broader literal meaning that the one normally conferred. The distinction between 'Sahrawi' and 'indigenous Western Sahara' is also used or ignored for different problematic purposes by Western Saharan nationalists and Morocco."Joshua Castellino and Elvira DomínguezRedondo, "The Identity Question: Who are the Sahrawis and What is their Home," in Perspectives on Western Sahara: Myths, Nationalism, and Geopolitics, edited by Anouar Boukhars and Jacques Roussellier. (New York: Rowman and Littlefield, 2014), 38.

${ }^{284}$ In Arabic, the form of Saharawi is a nisbah (adjective) that can either be modifying a person or referring to the geographical area.
} 


\section{CONCLUSION}

The Sahrawi are a group of people that currently inhabit Western Sahara proper or reside in the 'liberated zones' and the Algerian 'refugee' camps adjacent to these zones. The Kingdom of Morocco administers the Western Sahara except for a small sliver of desert land that the POLISARIO has branded as free or 'liberated zones.' In the meantime, most of the population has made their dwelling as guests of Algeria in the remote western Sahara that borders Mauritania, the liberated zones of the Western Sahara, and southern Morocco. Morocco appropriated the area, fought the POLISARIO for the land, and continues to negotiate with the UN (and POLISARIO). The question over its status of the Western Sahara has centered on the identity of the people: Who is a Sahrawi? The debate now surrounds the nature of Sahrawi national identity and questions whether one actually exists.

Although there have been several publications and reports about the political situation, there have been few sources detailing the debate over Sahrawi national identity. Of these works, only a handful have focused on Sahrawi nationalism and identity. These works highlight the problems that plague the definition of Sahrawi identity. They relate the Sahrawi experience in modern or constructivist terms and marginalize arguments derived from other theoretical frameworks. This work brings these frameworks together and through a Sahrawi socio-historical analysis has confirmed many of the findings of previous scholars. This project maintains that these conclusions about the roots of national identity can only be fully understood if the results of all theoretical frameworks are placed side-by-side. There are three ${ }^{285}$ major derived: 1) that the Sahrawi are a distinct grouping of people separated from neighboring peoples by language, territory, and custom; 2) that the Sahrawi struggle is an extension of anti-colonialism; or that 3) determined foreign and domestic actors appropriated Saharan identity for their own purposes. Each argument seeks answers to the origins of Sahrawi national identity and reflects respectively

${ }^{285}$ Chapter one introduced a fourth hypothesis that was not discussed extensively in this study based on ideological (liberty) arguments. 
the primordial, instrumental, and constructivist frameworks. Each chapter deals with all three perspectives.

The socio-historical timeline, which is not new to the study of Western Sahara, was used to try to pinpoint at what point in time or in which period can one establish the formal development of Sahrawi identity. Was there an inciting or landmark moment that could have made for the creation of a national identity in the past? Could there have been a proper period of growth or sense of national maturity for the Sahrawi at some point in history? And how could this identity have been created over time? The author has laid out five full chapters of historical analysis from antiquity to the invasion of Islam, from the Reconquista to early European encroachment, and finally from direct European colonization until 1973. This segment will offer conclusionary remarks for each period written.

Chapter three sought the origins of Sahrawi national identity from antiquity to 1524 when the army of the Sa'adian Dynasty overran a small Portuguese fort in Santa Cruz de Mar Peqeuña. Scholarship has not agreed on the original inhabitants of North Africa but lean toward the belief that groups of people migrated into the area. These groups were a mix of black from the southern regions of the continent, Arabs that traversed the great deserts into the northwest and southwest corners of North Africa, and an 'indigenous' Berber population. According to a primordialist framework any sense of homogeneity in the past may have resulted from social (nomadism), religious (Islam), or geographic (desert) factors. However, the territorial, as well as the spiritual argument is almost impossible to maintain because it would imply that all those under the banner of Islam and living as nomads in this vast expanse were of one mind or one identity. Even if this were so, there is no evidence to indicate that the region acted as one nation or that it identified itself as a nation.

As stated in chapter three, many scholars argue that the Sahrawi descend from the Berbers. A few authors insist that the genealogical trace goes even further back to the Bafour in 
5500 BCE. However, there are conflicting debates about the migratory patterns, emergence, and settlement of the Bafour in North Africa. The disparate nature of the research does not help in identifying these groups as forefathers of the Sahrawi. As to a Berber origin, there are debates as to the exact composition of Berbers and thus difficulty in differentiating them from other groups in North Africa. Nevertheless, the label has been steadily adopted today to include several minority nationalities across the Maghreb. Since the Sahrawi have claimed only the Western Sahara and not lands beyond this region, they have narrowed their genealogy to a smaller area of North Africa and the Sahara Desert. If only a geographical segment of the Berber population were the ancestors to the Sahrawi, the evidence has to show that they were a northwest African group directly linked to the modern Sahrawi. Disparate Berber groups even in greater northwest Africa, make it difficult to pinpoint continuity of a specific Berber population located in the extreme northwest corner of the Sahara.

Primordial arguments that maintain Sahrawi identity can be traced to antiquity assert that despite the hybridization of groups, the 'essence' of Sahrawiness (the matrix to their origins) develops between $50 \mathrm{BCE}$ and $400 \mathrm{AD}$. Scholars point to the beginning of the first century when independent societies of people distinguished themselves from the Roman-influenced part of the Maghreb. Groups, such as the Gaetulians, were outside Roman control and were largely nomadic in nature. Some of these independent groups were absorbed (through intermarriage or conflict) by the Sanhaja Berber. Most scholars consider the Sanhaja as direct ancestors to the Sahrawi. They resided in a vast triangular area of the desert whose sovereignty has been an area of contention for many centuries.

The weight given to these assertions is troubling. First, anthropological and ethnological scholarship cannot agree over the nature (the actual gene pool, migration routes) of their identity. Second, the Sanhaja were not a monolithic political entity, but rather a conglomeration of tribes. They later became the dominant confederation of tribes but the nature of their identity changed 
over time and makes it quite difficult to prove that the Sanhaja were true ancestors to the Sahrawi. The research indicates that from the eleventh through the sixteenth centuries the changes in the Sanhaja through invasion, intermarriage, and nomadism deeply fragmented Saharan society. The Sanhaja split into northern and southern branches after the rise of the Almoravid and Almohad Dynasties. The Sanhaja, already subdivided into several main tribes, became further fragmented when the Banu Maqil Arabs encroached on the greater Western Sahara. Dynastic changes began to mark differences among those who held affinity or loyalties to shaykhs (tribal chieftains) or other head tribesmen, especially in the upper northern areas of Morocco. Dynastic changes, the nature of the nomadic lifestyle, Arab intrusion, and disparate tribal affiliations led to a variable mix of ethnic identity. Therefore, if the Sanhaja are considered the direct ancestors of the Sahrawi, it is almost impossible today to ascertain which genealogical line of Sanhaja to follow because eventually the Sanhaja and its main branches faded through intermarriage and conflict. Moreover, recent scholarship has moved toward diversity of population origins in the Maghreb.

Chapter Four continues the search for the sources of Sahrawi national identity in the period beginning in 1524 until about 1757. The chapter acknowledges the effect of trade on tribal diffusion. This diffusion occurred, not only along the caravan routes of southern Western Sahara, but also among those tribes in the southern peripheries of Morocco, or northwestern Sahara. Settlements began to arise but these towns undertook sovereign qualities and sought control over the immediate southern Moroccan regions through intertribal warfare led by governors or sharifs. Domestic infighting, the rise of independent fiefdoms, Arab encroachment, the diminished power of the 'Moroccan' dynasties, (especially the Merinids) plagued the Western Sahara region. These attempted characteristics effectively allowed for several powers to vie for control of the region. Any power that attempted consolidating regional control would have been met with many opposing power-brokers. As a result, control garnered by any one tribe or conglomeration of tribes was temporary at best. 
The lack of power under one banner and the nomadic lifestyle afforded by the Sahara discouraged cohesiveness and allowed for subtle European intrusion. Most of these pockets of colonization were located on the coast, and if further inland, usually only along the major thoroughfares and points of trade. These small foreign incursions could not have been an obstacle to national collectivity. On the contrary, much of the lack of one identity sprang from (1) small independencies that broke ranks with other tribal groups; (2) tribal rivalries that fought for control of grazing land, trade routes, and blood feuds; (3) the weakness of dynastic and sharifian leaders who held only nominal power; (4) the challenge of organizing disparate nomadic tribes that preferred to stay clear of any type of subjugation; and (5) (if the claim is to pinpoint the origins of Sahrawi identity to the Sanhaja) the multiple divisions of the Sanhaja Berber have obscured the possibility of one lineage for the forbears of the Sahrawi. Therefore, primordial arguments do not actually fit these findings. Rather, it seems that they can only be explained through a constructivist framework.

Perhaps the only saving grace for primrodial arguments would be through Smith's ethnosymbolic lens. Ethnosymbolism recognizes that there are certain dynamics, influences that may not be found in purely primordial theory. Ethnosymbolism asserts that any national identity must include or at least allow for ethnic and cultural characteristics. These socio-cultural elements may either be contextualized from the past or derived from certain symbols that are deeply rooted to group identity. These symbols do not necessarily have to be found in the past but they are certainly tied to places or events in history. Dress, food, religion in general and nomadic behavior matter less than the appropriation of $\mathrm{Ma}$ ' 'Al-Aynayn as hero, Hassaniya as language, the use of sand and not water for the practice of Islam, or even historical events such as the 'war' against Spain, Mauritania and subsequently Morocco.

For example, I posed several questions to my interviewees when I visited the Sahrawi 'refugee camps' outside of Tindouf, Algeria between 26 September — 03 October 2014. Among 
these were: What did they believe the origins of Sahrawi national identity were based upon? Where do they believe the origins of their identity came from? The overwhelming majority of those interviewed focused on the heterogeneous nature of Sahrawi identity. It was most unusual (at least for the author) to hear them explain that this hybridization was unique to Sahrawi identity. All three of the representative 'ambassadors ${ }^{286}$ directly would state that their mixed heritage was undeniable. The SADR ambassadors to the UN and Spain, confirmed that indeed one cannot simply eliminate arguments derived from primordialism. The attachments that are tied to Sahrawi identity today may have been with its predecessors all this time but did not fuse to achieve the nationalism evident among the population today. The SADR representative to Spain asserted that the struggle is mainly a political one but "the political battle is based upon social, historical, ethnic, and cultural arguments... otherwise the political [argument] has no right" (Beyoun 2014). Along similar lines, the current SADR representative to the United States allowed for six elements that composed Sahrawi identity. He remarked that the Sahrawi are a hybrid of Arab, African, Berber, Spanish influence plus geography and a 'historical trajectory'... that "no other nation" had these features but the Sahrawi (Beisat 2013). However, the SADR representative to the UN who agreed with Mr. Beisat's sentiment, conceded that Sahrawi nationalism "was shaped on the battlefield...you cannot resist your...enemies without a clear and profound conviction that you are different_you are preserving your identity" (Boukhari 2013).

The director of the Sahrawi Cultural Museum, an anthropology graduate, responded slightly differently when she stated that: "any modern society will want to investigate their roots ... this is what happens with us, mainly when it involves a Bedouin society that is characterized by being in a disperse space, it does not have the notion to construct a very well-organized nation, or country...that was one of the questions, one of the concerns that modern Sahrawi society has had, is to begin with the historical act... it starts there" (Malainin 2014). The composition of the

\footnotetext{
${ }^{286}$ Ahmed Boukhari to the UN, Yeslem Beiset to the U.S., and Bouchraya Hamid Beyoun to Spain. Interviews conducted by the author, 2013 and 2014.
} 
tribes and resistance against invaders are an important part Sahrawi identity. These statements underscore how important it is to acknowledge that those arguments derived from primordialism because they establish a base of perennial beliefs that sustain an identity. It also demonstrates despite these low-level characteristics of identity; more is needed to fuse all these features into a nation. These features (territory, autonomy) were considered next.

While the great powers divided the continent of Africa at the end of the fifteenth century, apart from the issues of cohesion and tribal division, the period from the early sixteenth to midseventeenth century, revealed a new battleground over Sahrawi identity. Arguments for Sahrawi identity early in history were based on ethnic genealogy. Instead of arguing for certain markers of distinction, this period is highlighted by markers from or against certain territorial claims. The discussion moves to dissecting at what point there was control over the northwestern Saharan region by the political entities of northern Morocco. The Merinid and then Wattasid Dynasties were unable to consolidate control over the southern periphery. However, the Sa'adian Dynasty, led by Al-Mansur began the drive toward asserting dominion further south than Fes or Marrakesh. The now-titled Sultan of Morocco began to counter Portuguese, Spanish, Ottoman, and other contenders to the region. Still, the Sa'adians would not completely eradicate the Europeans because they were able to negotiate, reservedly, to maintain trade avenues and goods from Europe at specific points of entry on its coastline.

The Sa'adian rulers would move south, west, and southwest to check tribal rivalry, stop Christian incursions, and assert power. Scholarship establishes that these attempts to take territory and secure trade routes were temporary, nominal, and evidently unrecognized by other confederations of tribes. The most contentious of these areas was, and continues to be, the SARIO (Sequiet al-Hamra and Rio de Oro) region. The area ran from the northwestern coastline inland and turned southwestward and then even farther south into the Sahara Desert. This are has proven to be one of the biggest topics of debate for both parties to the conflict. Thus, the POLISARIO 
distance themselves from any claim by present-day Morocco that the Kingdom had dominion over that part of the territory in question. Several scholars, travelers of the period, and archival research surrounding cartographic borders of the period demonstrate that the Sa'adian Dynasty and subsequent rulers well into the Alawi Sultanate did not ever fully control these areas. It was not until late nineteenth century European colonization that there was ever one power controlling the Sous, Dra'a, and Sequiet el-Hamra River Valleys.

The territorial distinction asserted by the Sahrawi is derived from primordialism arguments. However, the territorial argument is complicated by the ethnic nature of the inhabitants. In fact, the marker of territory in the case of the Sahrawi is better sustained under constructivist arguments. Confederations that included the Reguibayt, Tekna, Tadjakant, Oulad Delim, and tributary tribes can only be identified as tribal or clan-like, not Sahrawi or Moroccan. The term 'Morocco,' based on cartographic archival research, seems to have been used as geographical designation rather than a delimitation of a nation. Thus, again, the employment of claims derived from primordial arguments is difficult because of identification discrepancies. In other words, a nation will usually identify not only with ethnic distinctions (such as religion, language, custom) but also with collective memories, and in this case, territorial rights. The only conceivable example that may have matched such a disparity were the Hebrews. Other invading groups such as the Huns, Goths, Mongols, and perhaps even the Vikings could possibly fit such national 'incongruence.' However, those groups have either disappeared completely or currently have a sovereign territory.

Nationhood is grounded in an assertion of territorial legitimacy and a socio-cultural dimension. Sahrawi have territorial claims and infer that they are distinct from Morocco, but the differentiation is not concretely grounded because of ties to a fragmented tribal society. Geography did not allow for any one power to control all of Western Sahara because of the vast distances and barren terrain. Tribes were small; confederations would number at most in the 
thousands. Thus, it is very challenging to label these tribes as small 'nations' or have them designated as part of some bigger cohesive nation. The notion of what constituted a nation would have had to be reconstituted to exclude territory at this time. Certainly then, there is no definitive national identity that can be defined as a Sahrawi nation in the period ending the seventeenth century. The lack of evidence marginalizes arguments from primordial approaches. Still, there seems to be no reason for eliminating the ethno-symbolic claim that the Sahrawi had never been dominated by 'Morocco' or any of its Sultans, especially south of the SARIO.

Chapter Five follows with the struggles by the Alawite Sultanate to force, coerce, or entice the more southerly Saharan tribes to acknowledge his authority from 1758 through 1859 . As stated previously, the Alawite Sultanate did at one time invade, subjugate, or coerce other Saharan political entities to submit to his spiritual authority. However, political authority over lands outside of direct Alawite influence was almost never recognized and when it was, it was nominal or temporary. In fact, even before the Alawites came to power in Morocco, the weak base of power in Marrakesh and Fes unsettled the dynasties especially among the Berber tribes in the Atlas Mountains. Power struggles appeared during the Alawite Dynasty. Despite each side pointing to the ICJ rulings for justification of their claims, controversy remains. Nevertheless, the controversy over territoriality is misplaced in context. The search is for roots of a certain national identity - a Sahrawi one - not for territorial control. Certainly this is important in the overall conflict but this answers a different question: Does the land belong to the Sahrawi? It does not answer at what point or from what point may one find the roots of Sahrawi national identity.

In the territorial debate, the question of the type of authority over those peripheral areas of Morocco arises. Morocco presently claims that although surrounding tribal entities did not thoroughly acknowledge the Sultan's temporal power, most of these groups recognized his spiritual authority. In this sense primordialists will argue that Islam is an objective element or innate part of Saharan society (at least after the Arab invasion). The POLISARIO asserts that the 
opposite is true. The Sultan's spiritual influence was respected, but it was not the kind of power that controlled the socio-political aspects of everyday life in any given political community. Morocco had requested that the ICJ allow for their case to be given 'special status' as their conviction relied upon the nature of the Sharifian state - a state that ruled primarily via spiritual consent rather than by coercion.

Yet, there are weaknesses for holding on to this 'spiritual' platform of authority. It may be a matter of perspective as to whether Islam was properly utilized as an issue of spiritual consent or was it rather a tool for coercion. Religion can influence minds, but it cannot exert actual physical force. Any extension of power that includes a 'spiritual' component must rely on the use of military force to gain 'real' dominance-especially territorial gains. Second, argumentation for the case of Morocco was based not on the religion itself but rather on its use and conditions of use. Third, it may seem that instead of any religious connotation, the Sultanates had exercised this mode of authority to expand and maintain economic interests - the Saharan trade routes. If this were the case, if Islam were exposed in its use for the consolidation of economic power, then it essentially becomes destitute of objectivism. Islam may have given the Sultan the general precepts for morality and a course of conduct for individual behavior but it could not have afforded a straight forward blueprint for conduct in war, governance, and economic exchange. If a sharif, governor, sultan, or tribal chieftain did so, the leader grounded the blueprint on a subjectivity that leads away from arguments derived from primordialism and toward those that lie with the framework for constructivism.

Chapter Five extends the counter-argument by introducing evidence that despite the Moroccan claim that most, if not, all of the greater Western Sahara, composed part of the Sultan's domain, it did not. In fact, the period approaching the end of the eighteenth century was one of fragmentation and re-composition among the tribal areas of the Western Sahara. Questions remained surrounding who controlled the southern peripheries of 'Morocco' even in the presence 
of a strong Alawite Dynasty. Moreover, several independencies arose that not only competed amongst each other for power but also ignored both the Sultan's temporal and spiritual authority.

Counter-claims against the Moroccan historical precedent to dominion over the land in question include the archival evidence and still-to-be fully studied (and translated) Saharan documents. European encroachment steadily increased and contributed to more contact with the local inhabitants in the greater Western Sahara. Several agreements and treaties between the Sultans and the great European powers demonstrated, albeit somewhat ambiguously, that Morocco's frontiers were limited to certain geographical areas. Second, Saharan documentation, discovered in the past fifty years, has revealed certain curiosities of Saharan history. These Saharan scholars write that there were, in fact, a number of independent societies scattered throughout the greater Western Sahara. These documents indicate that there were other power brokers, lines of division, and accounts of history that have not been thoroughly analyzed. These manuscripts contradict a monolithic state of Moroccan dominion over the Western Sahara.

None of these arguments indicate a distinct Sahrawi identity. The rise of Independent political entities, foreign agreements that indicated the vagueness of the Sultan's dominion, and manuscripts depicting a literary and historical period independent of 'Moroccan' dominance actually establishes the opposite. Certainly, the European pacts do not prove that there was a Sahrawi nation but center on the territorial argument. The seventeenth and eighteenth century Saharan manuscripts depict a Sahara that had well-established societies, including trade, an Islamic clergy, a flourishing (much to be translated) literature, and a certain hierarchy among its inhabitants. However, there is no evidence as yet to suggest there were clans or tribes that composed a specific Sahrawi 'nation.' In fact, the documents offer a different view. They indicate that there were many independent political identities but none (at this point) (either specific individuals or groups) that identified themselves as Sahrawi. In general, the research conveys the idea that rather than there being one cohesive Saharan identity, there were many. There is an 
argument for stating that there was one massive Saharan identity which included the environment (desert landscape), lifestyle (nomadism) (except for some, more urbanized, southern and northern political communities), religion, and raiding. Saharan society, however, consisted of many tribal confederations and desert emirates. It is simply difficult to validate, not only the territorial claim by Morocco, but also the Sahrawi ‘self-awareness' claim by the POLISARIO.

Chapter Six (1860-1883) begins with similar difficulties in terms of seeking the origins of Sahrawi identity. Several authors state that Morocco suffered from internal turmoil, that the Western Sahara was not under any direct control, and several tribes and tribal confederations governed their own state of affairs. The newly-discovered Saharan history has demonstrated that there was, in fact, a separate chronicle of Saharan society, different from that of the well-known Moroccan record. These documents (at least the ones that have been translated and made available) show that there were other political communities living apart from the influences of the Sultan and independent of his authority. Based on several writings, it is clear that these tribal groups fought amongst each other for resources and rivalries. They conducted raids. The overwhelming number of battles fought between and among tribes occurred without the consent of the Sultan, and indicated the independent action of each tribe or alliance of tribes.

Tribal organization, an issue that in a much earlier period was the focus of criticism, was also briefly mentioned. Most pro-Moroccan scholars and skeptics of organizational structures in Saharan society debate whether there was any semblance of order or tribal accountability. In fact, sources claim that the Moroccan Sultan, when given the opportunity, swept through a territory, implemented, and subsequently maintained 'order.' However, Chapter Six proves that far from disorder, there was collective tribal responsibility, dedication to the agricultural cycles of farming, a process to suspend battle with each other. Many tribes used mediation to resolve differences. In addition, unruliness and disorder within Moroccan lands could have rivaled at times the Saharan chaotic lifestyle that some western scholars describe. These issues compounded 
the governance problem for the Sultan whenever he attempted to advance his authority beyond 'Morocco.'

Still, the attempt to answer the question of Sahrawi national identity is distant even in this period. Sahrawi origins do not begin here. There are no primordialist-derived arguments that can sustain a basis for Sahrawi national identity. Arguments that arrive at answering the roots of identity via constructivism seem more reasonable but there does not seem to be a strong cohesive, viable catalyst bringing together these disparate tribes. Any claims that try to establish Sahrawi roots through an instrumentalist justification is just as difficult. The only political entities that could have aided in the fusion of a Saharan identity were those directed from Morocco or from the Europeans. Yet, direct European control (except perhaps by the French in the extreme south in the vicinity of the Senegal River Valley) was not yet significant. Moroccan suzerainty was nominal and temporary. Even a conglomeration of the independent tribal affiliations did not converge en masse to 'claim' the northwestern Sahara. As such, there is no concrete, viable evidence to determine at this stage, as late as the 1850 s, that there was a developing Sahrawi nation.

Chapter Seven (1884-1973) details the pressing and more determined efforts by the Great Powers of Europe to encroach on the northwestern Sahara. They began from the south, at the mouth of the Senegal River, and from the north in northern Morocco. The Spanish had aspirations in southern Morocco, certain enclaves in the north, and on the coastal areas of Western Sahara proper. The treaties and agreements that would pepper the following years with Morocco and a few of the emirates and political communities in and around the Western Sahara demonstrate the slow but increasingly more influential European involvement in the region. The European powers generally perceived the inherent weakness of the Moroccan Sultan. Revolts from the local inhabitants, the attraction of market opportunities via the Saharan trade routes and coastal trading, the geo-political and economic importance of the Straits of Gibraltar, and the internecine conflict 
among and within tribes in and around the Kingdom of Morocco allowed for the encroachment of the foreign powers. The beginning of chapter seven highlights the rise of strong independent tribal confederations and emirates along with other, smaller, but just as independent, tribal groups. These independent tribes and other political communities began to rival the Sultan and indeed began to negotiate with the foreign 'infidels.' There is ample evidence to support not only independent tribal freedom of movement but also negotiated settlements with the foreign 'infidels.' They did not seek approval of the Sultan despite the official arguments against this possibility.

Thus, despite the vast distances and the prevalence of nomadism, the region developed political entities acting independently of supposed powers that claimed authority over most of the northwest and Western Sahara. Indeed, the evidence strongly suggests that the Sultan, while at times moving forces across some of the landscape, congratulating 'subject' leaders, granting investitures, and warring with competitors, never had complete, sovereign control over these autonomous principalities. Moreover, many, if not all, of the groups in question would only temporarily, and for political expediency, recognize the Sultan's authority. Groups such as the Tekna, Reguibayt, the Oulad Delim, Oulad Tidrarim, Arosien, the Tadjakant, Walati, Kunta, and a surge of smaller groups of tribes, kingdoms in the Sous and Goulimine, and emirates in the Adrar, of Brakna, Trarza, and Tagant operated independently.

The general picture then from the accounts in Chapters Six and Seven reveals that neither the Moroccan kingdom nor any Saharan 'nation' had proprietary control over these disputed regions. Primordial and instrumental interpretations (in the mid-eighteenth to late nineteenth centuries) cannot support the development of any one dominating Saharan nation. In fact, Saharan history chronicles several large political communities cohabitating, warring, and trading with each other. There is not enough support for instrumental and primordial arguments to sustain group ancestry with the ancient version of the Sanhaja Berber because of the increasing nature of 
hybridization via marriage among Berber, Moor, Arab, and Black. There is difficulty in establishing Sultanate supremacy over these lands. If one views the dynamic nature of the northwestern and Western Sahara through a more constructivist approach, there is also the challenge of building one distinct, self-aware Saharan identity that can be identified as 'Sahrawi.' The economic and socio-cultural fabric of Saharan society might have been very similar but this overlay of Saharan civilization was apparently severely divided among the disparate and 'roaming' tribes of the northwestern Sahara.

Of all the developments explained in Chapter Seven that conspired to reduce the assertions that the Sultan had control over the territory, three of the four focus on the interests and actions of the European powers. The fourth development, the adherence of these groups to tribal identity rather than some type of national identity, deterred the unification of tribes. It is almost impossible to argue for a coalescing national Saharan identity. The first three developments aid in the development of a sentiment that had been held ever since the intrusion of the early colonizers: feelings of irritation against increasing European interference in their daily affairs turned into outright hostility. Direct confrontation became inevitable. By 1912, the first revolts targeted the major European territorial powerbrokers (France and Spain) and the charismatic personality of Ma' al-'Aynayn led the uprising. These hostilities led to an enhanced awareness of Saharan identity caused by the juxtaposition between the perceived threat of European identity and their already established Saharan self.

The exploits of Ma' al-'Aynayn are central to a 'Saharan' awakening. On the one hand, the Sahrawi have appropriated this historical antecedent as part of their collective memory and a primordial feature of their national identity. On the other hand, he can also be considered part of the great man concept of history ${ }^{287}$. If so, then his influence would fall under the instrumentalist arguments. Ma' al-'Aynayn is the clearest example of an entrepreneur guiding Saharan identity.

\footnotetext{
${ }^{287}$ A largely nineteenth century concept that explains how history has been influenced by great men and women, rulers, or highly influential individuals
} 
His goals, however, were short-sighted. He was angry that Europeans had encroached onto sacred lands, and his first objective was to oust them. Later, disgusted with the policies of appeasement by the Sultan of Morocco, he decided to take the throne. It is not clear, though, whether his ambition included the building of a nation for the whole of Western Sahara. Scholars note that he was not Moroccan born but from the deep south. He settled south of the Dra'a River Valley, and founded the city of Smara. Clearly he a catalyst of Saharan awareness and brought together disparate tribes against the colonial powers, but his untimely death stopped what could have been a Sahrawi nation. This struggle, however, as Ambassador Boukhari suggests was a key moment in Sahrawi history because it began to shape the notion of a Sahrawi identity 'on the battlefield' (Boukhari, 2014). The struggle continued for more than three decades after his death but was overcome decisively.

The liberation of Morocco from the French brought together many of the tribes of the Spanish Sahara. The tribes believed that, in turn, that the Sultan would help them against the French and Spanish in what was already considered Spanish territory. However, the awaited reciprocity never came. Although not all tribes had acquiesced to liberating the territory, Sahrawi awareness had arrived. The moment this confederation of tribes collaborated in a concerted effort to free themselves from the Europeans in 1954-1956, they had created an identity rooted in opposition. Not all tribes had formally asked the Sultan for help, but the major tribes within the Spanish Sahara were present. By organizing themselves as a group, they had adopted the territory of the Spanish Sahara and all of its history. Divisions did surface eventually because of group interests, but with the formation of the POLISARIO Sahrawi identity crystalized.

At the beginning of the search, the author believed that the origins of Sahrawi national identity lay deep in history. Their origins must have included certain features unique to the Sahrawi or adopted by them sometime in history. However, Sahrawi 'history' is a mélange of elements. In addition, to the author's surprise, almost all the interviewees admitted that the roots 
of Sahrawi identity were historically numerous. In other words, although there are various features of identity, the primordial hypothesis did not help in pinpointing when the Sahrawi fused as a nation. Still, a Sahrawi nation would not have been possible without these basic elements of identity. For precisely this reason, primordial arguments cannot be discarded. What this study has presented is a prolonged search via primordial (historical and socio-cultural), instrumental (the leadership of Ma al-'Aynayn and the development of autonomous tribes), and constructivist arguments (territorial boundaries set by the French and Spanish) for the origins of Sahrawi national identity. This author has found their origins belong in the period of history beginning with the leadership of Ma al-'Aynayn (1904) and culminating with the creation of the POLISARIO (1973).

This study acknowledges that constructivist accounts of identity formation are a great tool for understanding national identity. Its arguments can produce evidence which, placed in context, can generate a picture of national identity. However, constructivism needs refinement when pieces of evidence, as in the case of the Sahrawi, come from different segments of history. History is an assortment of events and socio-cultural markers. These markers are ethno-cultural resources adopted by groups that developed over time and by themselves may be insignificant. The sum of these distinguishing resources, socio-historical features and experiences must all be included, accounted for, and then evaluated for an end result. This study places the moment of Sahrawi national identity in the twentieth century but adds that this conclusion utilizes essential markers of differentiations that persist over time; they are the building blocks of any national identity. 


\section{WORKS CITED}

"Convenio con Marruecos 28 Mayo, 1767, Tratado de Paz con Marruecos." Estado 3372, Carpeta \#11, Número 1 y 2, Archivo Histórico Nacional de España. Madrid, España.

"Nouvelles et Faits Divers." La Presse June 14, 1844. BnF (Bibliothèque nationale de France). Gallica.bnf.fr. Accessed August 12, 2015.

"Safi." In Encyclopedia Britannica, Chicago: Encyclopedia Britannica, 2015. Accessed February 11, 2015. http://www.britannica.com/EBchecked/topic/516146/Safi.

“Tratado de Paz, Amistad, Navegación, Comercio Y Pesca, entre S. M. [Su Majestad] Cat. [Católico] Y S. M. Marroquí concluido y firmado en Mequínez á 1 de Marzo de 1799,” Tratado con Marruecos. Madrid: La Imprenta Real. Archivo Histórico Nacional de España, Estado, Legajo 4350, No. 1 (Caja No.1).

"Western Sahara Volume V Oral Statements (Concluded) \& Correspondence.” International Court of Justice, Pleadings, Oral Arguments, and Documents, 1982.

“Western Sahara, Advisory Opinion of 16 October 1975," International Court of Justice, Reports of Judgments, Advisory Opinions and Orders, 1975 (11-82).

"Wolof Empire." Encyclopedia Britannica, Chicago: Encyclopedia Britannica, 2015. Accessed July 22, 2015, http://www.britannica.com/place/Wolof-empire\#ref221633.

Abi-Mershed, Osama and Adam Farrar. "A History of the Conflict in Western Sahara.” In Perspectives on Western Sahara: Myths, Nationalism, and Geopolitics, edited by Anouar Boukhars and Jacques Roussellier. New York: Rowman and Littlefield, 2012.

Abun-Nasr, Jamil M. A History of the Maghrib in the Islamic Period. New York: Cambridge University Press, 1987. . A History of the Maghrib. New York: Cambridge University Press, 1971.

Africanus, Leo. The History and Description of Africa and of the Notable Things Therein Contained Vol. 1, edited by Dr. Robert Brown. London: Bedford Press, 1896. 
Aggad, Faten and Pierre du Toit Botha. "Revisiting the Western Sahara Conflict." Africa Insight 35, no.1 (April 2005): 65-75.

Alberola Romá, Armando and Rosario Die Maculet. "El Autor: Jorge Juan Santacilia—Marino y Científico (Perfil Biográfico)." www.cervantesvirtual.com. Biblioteca Virtual Miguel de Cervantes. Accessed June 2015. http://www.cervantesvirtual.com/portales/jorge juan_santacilia/autor_biografia/.

Algueró Cuervo, José Ignacio. El Sahara y España: Claves du una Descolonización Pendiente. Las Palmas de Gran Canaria: Ediciones Idea, 2006.

Anderson, Benedict. Imagined Communities: Reflections on the Origin and Spread of Nationalism. Revised Edition. New York: Verso, 2006.

Arieff, Alexis. “Western Sahara.” Congressional Research Service. RS 20962, 0ctober 82014. 2013.

"Morocco: Current Issues." Congressional Research Service. RS21579, October 18,

. "Western Sahara." Congressional Research Service. April 05, 2012.

. "Western Sahara.” Congressional Research Service. RS20962, February 15, 2011.

Armstrong, John A. Nations Before Nationalism. Chapel Hill: University of North Carolina Press, 1982.

Bank, André and Bas Van Heur. "Transnational Conflicts and the Politics of Scalar Networks: Evidence from Northern Africa." Third World Quarterly 28, no. 3 (207): 593 - 612.

Barbier, Maurice. Le Conflict du Sahara Occidental. Paris: L'Harmattan, 1982.

Barrington, Lowell W. “'Nation' and 'Nationalism': The Misuse of Key Concepts in Political Science.” Political Science and Politics 30, no.4 (December 1997): 712-716.

Beisat, Mohamed Yeslem. Interview conducted with the SADR Ambassador to the U.S. 11 November 2013. 
Besenyő, János. Western Sahara. Budapest: IDResearch Ltd./Publikon Publishers, 2009.

Beslay, François, Les Reguibats: De la Paix Française au Front POLISARIO. Paris: L’Harmattan, 1984.

Beyoun, Bouchraya Hamid. Interview conducted with the SADR representative to Spain. 25 July 2013.

Boilat, Abbé David. "Carte des Peuples Du Sénégal“" [map]. In Esquisses Sénégalaises: Physionomie du Pays-Peuplades-Commerce-Religions Passé et Avenir Récits et Légendes. Paris : Librairie P. Bertrand, 1853, 512. Gallica.bnf.fr. - Bibliothèque Nationale de France. http://gallica.bnf.fr/ark:/12148/bpt6k103361c/f512.image. Accessed June 122015.

Bonte, Pierre. "Kinship and Politics: The Formation of the State among the Pastoralists of the Sahara and the Sahel." In The Study of the State, edited by Henri J.M. Claessen and Peter Skalník, New Babylon: Studies in the Social Sciences, 35-58. New York: De Greyter Mouton, 1981.

Bonte, Pierre. "La Constitution de l'Émirat de l'Adrar: Quelques Hypothèses Provisoires.” In: Revue de l'Occident Musulman et de la Méditerranée N³2, (1981): 37-51.

Bontems, Claude. "The Government of the Saharawi Arab Democratic Republic." Third World Quarterly 9, no.1 The Politics of Exile (January 1987): 168-186.

Bosworth, C.E., E. Van Donzel, B. Lewis, and Ch. Pellat, eds. The Encyclopedia of Islam Volume 5, Leiden: E.J. Brill, 1983. Accessed September 24, 2015. https://books.google.com/books?id=jJY3AAAAIAAJ\&pg=PA890\&lpg=PA890\&dq=des cendants + of + Al-Aynayn\&source $=$ bl\&ots $=$ ef $4 z-$ heO1P\&sig=9495kGL7SM1nO4gpc2ZEPGYbsHI\&hl=en\&sa=X\&ved=0CC8Q6AEwB WoVChMIhqjx -eNyAIVgmweCh2UrAHh\#v=onepage\&q=descendants\%20of\%20AlAynayn\&f=false. Google Books.

Bouasria, Abdelilah. Sufism and Politics in Morocco: Activism and Dissent. New York: Routledge, 2015.

Boukhari, Ahmed. Interview conducted with the SADR Ambassador to the UN. 11 November 2013. 
Brass, Paul R. Ethnicity and Nationalism: Theory and Comparison. Newbury Park, CA: Sage Publications, 1991.

Brent, Michael and Elizabeth Fentress. The Berbers. Malden, MA: Blackwell Publishing, 1997.

Breuilly, John. Nationalism and the State. Chicago: University of Chicago Press, 1994.

Briones, Felipe, Mohamed Limam Mohamed Ali, and Mahayub Salek. "Luali: 'Ahora o Nunca, La Libertad'." (Alicante: Universidad de Alicante, 1997), 38-39. Quoted in San Martín, Pablo. Western Sahara: Refugee Nation. Cardiff: University of Wales Press, 2010.

Brooks, Nick, Savino di Lernia, Nick Drake, Margaret Raffin and Toby Savage. "The Geoarchaeology of Western Sahara: Preliminary Results of the First Anglo-Italian Expedition in the Liberated Zone." Sahara Journal (January 2003): 1-27.

Brown, Leon Carl. "Color in Northern Africa." Daedalus 96, No. 2 Color and Race (Spring 1967): 464-482.

Bullard, E. G. 2001. "Berbers in Antiquity and Carthage." In Africa and Africans in Antiquity, Africa and Africans in Antiquity, edited by Edwin A. Yamauchi, 180-209. East Lansing, MI: Michigan State University Press.

Burke III, Edmund. "The Image of the Moroccan State in French Ethnological Literature: A New Look at the Origin of Lyautey'a Berber Policy." In Ernest Gellner and Charles Micaud, eds. Arabs and Berbers: From Tribe to Nation in North Africa. London: D.C. Heath and Company, 1972.

Cabot Briggs, Lloyd. Tribes of the Sahara. Cambridge: Harvard University Press, 1960.

Caddeo, Rinaldo, ed. "Le Navigazioni Atlantiche di Alvise da Cá da Mosto" (Milan, 1929). In The Portuguese in West Africa 1415-1670: A Documentary History. Translated by Malyn Newitt. New York: Cambridge University Press, (2010) 67-71.

Camps, Gabriel. "Les Gétules, Guerriers Nomades dans l'Africa Romaine.” CLIO. July 2002, Accessed July 30, 2016. https://www.clio.fr/BIBLIOTHEQUE/les_getules_guerriers_nomades_dans_1_africa_ro $\underline{\text { maine.asp\#biblio }}$. 
Canales Torres, Carlos and Miguel del Rey Vicente, eds. Breve Historia de la Guerra de IfniSáhara. Madrid: Ediciones Nowtilus, 2010.

Caratini, Sophie. Les Rgaybat (1610-1934) Tome 1 and 2: Des Chameliers à la Conquête d'un Territoire. Paris: L'Harmattan, 1989.

Caro Baroja, Julio. Estudios Saharianos. Madrid: Calamar Edición y Diseño, 2008.

Castellino, John and Elvira Dominguez-Redondo. 2014. "The Identity Question: Who are the Sahrawis and What is Their Home?" In Perspectives on Western Sahara, edited by Anouar Boukhars and Jacques Roussellier, 29-51. New York: Rowman and Littlefield.

Cleaveland, Timothy. Becoming Walata: A History of Saharan Social Formation and Transformation. Portsmouth, NH: Heinemann, 2002.

Connor, Walker. Ethnonationalism: The Quest for Understanding. Princeton, NJ: Princeton University Press, 1994.

Cotton, (Lt.-Gen.) Sir Arthur. The Story of Cape Juby. London: Waterlow and Sons, 1894. Hathi Trust Digital Library/Digitized by Google Play Books. Accessed September 162015. http://hdl.handle.net/2027/hvd.32044088653340

Crétois, Jules and Mohammed Boudarham, "Jihadists Returning from Syria Pose Threat to Morocco." Al-Monitor. 20 May 2014. www.al-monitor.com. Accessed May 19, 2016. http://www.al-monitor.com/pulse/security/2014/05/morocco-jihadists-fighting-syriarisks-return.html\#

Criado, Ramón. Sahara : Pasión y Muerte de un Sueño Colonial. Chatillon-sous-Bagneux: Imprimerie SEG, 1977.

Croucher, Sheila L. Imagining Miami: Ethnic Politics in a Postmodern World. Charlottesville, VA: University Press of Virginia, 1997.

Challis, William, Alec Campbell, David Coulson, and Jeremy Keenan. 2007. "Funerary Moments and Horse Paintings: A Preliminary Report on the Archeology of a Site in the Tagant Region of Southeast Mauritania-Near Dhar Tichitt.” In The Sahara: Past Present and Future edited by Jeremy Keenan, 281-298. Adobe Digital Editions. New York: Routledge. 
D’Almonte, Enrique. Ensayo de una Breve Descripción del Sáhara Español. Madrid: Imprenta del Patronato de Huérfanos de Intendencia e Intervención Militares, 1914. Reprint by University of Michigan.

Damis, John. Conflict in Northwest Africa: The Western Sahara Dispute. Stanford, CA: Hoover Institution, 1983.

Danver, Steven, ed. Native Peoples of the World: An Encyclopedia of Groups, Cultures, and Contemporary Issues. Vol 1-3, New York: Routledge, 2013.

De La Chapelle, F. “Esquisse d'Une Histoire du Sahara Occidental.” Hespéris XI (1930): 35-95. Accessed September 07, 2015. http://www.etudesahariennes.ma/index.php/bibliothequenumerique/articles/138-la-chapelle-f-de-esquisse-d-une-histoire-du-sahara-occidental. Centre des Études Sahariennes-Université Mohammed V (Rabat).

Del Riquelme, Pasqual. 1991. "Historia de los Saharauis y Cronica de la Agresion Colonial en el Sahara Occidental.” PhD diss., Universidad Complutense de Madrid.

Désire-Vuillemin, G Geneviève-M. "Cheikh Ma El Aïnin et le Maroc, ou l'Échec d'un Moderne Almoravide." Revue d'histoire des Colonies. Tome 45 (158), 1958, 29-52.

. 1962. "Contribution a L'Histoire de la Mauritanie: 1900-1934.” MA thesis, Université de Montpellier.

Deubel, Tara Flynn. "Between Homeland and Exile: Poetry, Memory, and Identity in Sahrawi Communities." Ph.D. diss., University of Arizona, 2010.

. "Poetics of Diaspora: Sahrawi Poets and Postcolonial Transformations of a TransSaharan Genre in Northwest Africa." The Journal of North African Studies 17, no. 2 (2011): 295-314. Accessed June 9, 2015. http://dx.doi.org/10.1080/13629387.2011.610591.Taylor and Francis Online. http://www.tandfonline.com/doi/abs/10.1080/13629387.2011.610591.

Diario ABC. 1975. "Se Descifra un Documento sobre la Frontera del Sahara y Mauritania." March 07.

Dirección General de Promoción de Sahara e Instituto de Estudios Africanos. El Sahara como Unidad Cultural Autóctona. Comisión Hispano-Saharaui de Estudios Históricos y Culturales. Madrid: Consejo Superior de Investigaciones Científicas, 1975. 
Discours de feu Sa Majesté Hassan II (Le 16 octobre 1975 à Marrakech). Portail Du Sud Marocain-Agence pour la Promotion et le Développement Economique et Sociale des Provinces de Sud du Royaume. www.agencedusud.gov.ma. Accessed May 23, 2016. http://www.agencedusud.gov.ma/download/discours-SM-HassanII-75-marrakech.pdf .

Doutté, Edmond. En Tribu: Mission au Maroc. Paris : Librairie Paul Geuthner, 1914.

Dunn, Ross E. "The Ait Atta Expansion in Southeast Morocco," in Arabs and Berbers: From to Nation in North Africa, edited by Ernest Gellner and Charles Micaud, 85-107. London: Duckworth and Company, 1973.

El Hamel, Chouki. Black Morocco: A History of Slavery, Race, and Islam. New York: Cambridge University Press, 2013.

E1 Mazouni, Mohamed. "Political and Religious Institutions under the Saadians." 2012. In Dominique Avon, Politics Religion and State Building $\left(11^{\text {th }}-16^{\text {th }} / 19^{\text {th }}\right.$ Centuries). Translated by Francoise Pinteaux-Jones. Accessed July 22, 2015. http://hemed.univlemans.fr/cours2011/en/co/grain2 2 1.html.

Ensel, Remco. Saints and Servants in Southern Morocco. Boston: Koninklijke Brill NV, 1999.

Ergang, Robert Reinhold. Herder and the Foundations of German Nationalism. New York: Octagon Books, 1966.

Farah, Randa. "Refugee Camps in the Palestinian and Sahrawi National Liberation Movements: A Comparative Perspective.” Journal of Palestine Studies 38, No. 2 (Winter 2008): 7693.

"Western Sahara and Palestine: Shared Refugee Experiences." In African Displacement: Roots, Resources and Resolution. Forced Migration Review 16 (January 2003): 20-23. Oxford: Refugee Studies Center and Norwegian Refugee Council/Global IDP Project.

Flint, John E. The Cambridge History of Africa from c. 1790 to c. 1870. Vol. 5. New York: Cambridge University Press, 1976.

Gaudio, Attilio. Les Populations du Sahara Occidental: Histoire, Vie et Culture. Paris: Karthala, 1993. 
Geertz, Clifford. The Interpretation of Cultures: Selected Essays. New York: Perseus Books, 1973.

Gellner, Ernest and Charles Micaud, eds., Arabs and Berbers: From Tribe to Nation in North Africa. London: Gerald Duckworth and Company, 1973.

Gellner, Ernest. Nations and Nationalism. New York: Cornell University Press, 1983.

Gerth, H. H. and C. Wright Mills, eds. and trans. On Max Weber: Essays on Sociology. New York: Oxford University Press, 1946.

Ghirelli, Angelo. El País Berebere: Contribución al Estudio de los Orígenes, Formación y Evolución de las Poblaciones del África Septentrional. Madrid: Editora Nacional, 1942.

Grosby, Steven. "The Inexpungeable Tie of Primordiality." In Ethnicity, edited by John Hutchinson and Anthony D. Smith, 51-56. New York: Oxford University Press, 1996.

Haggard, Juan Villasana. Handbook for Translators of Spanish Historical Documents. Austin, TX: University of Texas. 1941, Google Play Books.

Hall, Bruce S. "The Question of Race in the 'Pre-Colonial Southern Sahara." in The Sahara: Past, Present and Future, edited by Jeremy Keenan, 134-176. New York: Routledge, 2007. Google Play Books.

Hasan Mohamed, Mohamed. Between Caravan and Sultan: The Bayruk of Southern Morocco-A Study in History and Identity. Boston: Koninklijke Brill, 2012.

Hasnaui, Zahra. "Patrimonio Cultural y Creaciones Artísticas e Intelectuales del Sahara Occidental." In Universidad y Sahara Occidental: Reflexiones para la Solución de un Conflicto, edited by Pedro Martínez Lillo, Silvia Arias Careaga, Carlos Tanarro Alonso, and Julia Weingärtner (Coords.), Oficina de Acción Solidaria y Cooperación Universidad Autónoma de Madrid, 201-204. Madrid: R. B. Servicios Editoriales, 2009.

Hertslet, E., Sir ed. The Map of Africa by Treaty. $3^{\text {rd }}$ edition. London: His Majesty's Stationary Office, 1909. Quoted in Frank E. Trout Morocco's Saharan Frontiers. Geneva: Librarie Droz, 1969. 
Hobsbawm, Eric and Terence Ranger, eds. The Invention of Tradition. New York: Cambridge University Press, 1983.

Hobsbawm, Eric J. Nations and Nationalism since 1780: Programme, Myth, and Reality. New York: Cambridge University Press, 1990.

Hodges, Tony. "The Origins of Sahrawi Nationalism." Third World Quarterly, Vol 5 (1) January 1983, 28-57.

. “The Western File.” Third World Quarterly 6, no. 1 (January 1984): 74-116.

. Western Sahara: Roots of A Desert War. Westport, CT: Lawrence Hill and Co., 1983.

Husaen Syed, Muzaffar, Syed Saud Akhtar and Babuddin D. Usmani, eds. A Concise History of Islam. New Delhi: Vij Books India, 2001.

Huß, Werner (Bamberg). "Numidae, Numidia." Brill's New Pauly. Antiquity volumes edited by Hubert Cancik and Helmuth Schneider. Brill Online Reference Works, 2015. http://referenceworks.brillonline.com/entries/brill-s-new-pauly/numidae-numidiae826540. Accessed 22 August 2014.

Hutchinson, John and Anthony D. Smith, eds. Ethnicity. New York: Oxford University Press, 1996.

Idjennaden, Bob. The Forgotten Civilizations of Africa: The Gaetulian Warriors. No Place of Publication: No Publisher, 2012. Kindle for Mac.

Ilahiane, Hsaine. Historical Dictionary of the Berbers (Imazighen). Historical Dictionaries of Peoples and Cultures, no. 5 (Lanham, Maryland: Scarecrow Press), 2006.

International Crisis Group (ICG). Western Sahara: The Cost of the Conflict. Middle East/North Africa Report, No. 65. Brussels, June 11, 2007.

Isaacs, Harold Roberts. Idols of the Tribe: Group identity and Political Change. New York: Harper and Row, 1975. 
Jacques-Meunié, D. Le Maroc Saharien, des Origines à 1670, 2 Volumes. Paris: Les Belles Lettres, 1982.

Jaén, Antonio. España Extrapeninsular: Marruecos. Sahara, Rio de Oro, Guinea, Islas. Sevilla: Eulogio de las Heras, (1926): 41. Quoted in Pablo San Martín, Western Sahara: Refugee Nation. Cardiff: University of Wales Press, 2010.

Jensen Erik. Western Sahara: Anatomy of a Stalemate. Second Edition. Boulder, CO: Lynne Rienner Publishers, 2005.

Johnson, Douglass. "The Maghrib: Political, Social and Economic Conditions before 1830." In The Cambridge History of Africa, Volume 5, from c.1790 to c.1870, edited by John E. Flint, 99-124. New York: Cambridge University Press, 1976.

Johnston, Sir Harry H. A History of the Colonization of Africa by Alien Races. New York: The Macmillan Company, 1899. Google Play Books.

Julien, Charles-André. Translated by John Petrie. History of North Africa-Tunisia, Algeria, Morocco: From the Arab Conquest to 1830. London: Routledge and Kegan Paul, 1970.

Keenan, Jeremy, ed. The Sahara: Past Present and Future. New York: Routledge, 2007.

Khoury, Rana B. "Western Sahara and Palestine: A Comparative Study of Colonialisms, Occupations, and Nationalisms." New Middle Eastern Studies 1 (2011). http://www.brismes.ac.uk/nmes/archives/321.

La Courbe, Michel Jajolet de la Courbe. "Premier Voyage du Sieur de La Courbe Fait à la Coste d'Afrique en 1685." (1685): 245. Quoted in H. T. Norris, The Arab Conquest of the Western Sahara. Arab Background Series. Harlow, UK: Longman Group, 1986.

La Presse. Edition de Paris. 1844. "Nouvelles et Faits Divers.” Friday, June 14.

La Realidad: Diario Bilingue de Sahara. 1975. "El Sahara, Unidad Cultural Autóctona: Una Investigación de la Comisión de Estudios Históricos: Jat al Jaof, Frontera Historica de Sahara." June 21. http://jable.ulpgc.es/jable/cgibin/Pandora.exe? $x$ slt $=$ ejemplar;publication $=\mathrm{La} \% 20$ Realidad; day $=21 ;$ month $=06$; year $=197$ 5;page $=0001 ;$ id $=0007402198 ;$ collection=pages;url high=pages $/$ La\%20Realidad $/ 1975 / 19$ 7506/19750621/19750621-0001.pdf;lang=es; encoding=utf-8 . Accessed August 28, 2016. 
Lakhal, Malainin and Ahmed Khalil, Pablo San Martin, eds. "Moroccan Autonomy for the Western Sahara: A Solution to a Decolonisation Conflict or a Prelude to the Dismantking of a Kingdom?" Review of African Political Economy 33, no. 108. North Africa: Power, Politics and Promise (June 2006): 336-341.

Lampriere, William. A Tour through the Dominions of the Emperor of Morocco, London: Tayler and Co, 1813 .

Laroui, Abdallah. The History of the Maghreb: An Interpretive Essay. Translated by Ralph Manheim. Princeton, NJ: Princeton University Press, 1977.

Law, R. C. C. "North Africa in the Period of Phoenician and Greek Colonization, c. 800 to 323 BC." In The Cambridge History of Africa: From c. 500 BC to AD 1050, Vol. II edited by J. D. Fage, 87-209. New York: Cambridge University Press, 1978.

Le Quellec, Jean-Loïc. 2008. "What's New in the Sahara, 2000-2004?” In Rock Art Studies: News of the World, Vol. 3, edited by Paul Bahn, Natalie Franklin, and Matthias Strecker, 52-88. Oxford: Oxbow Books.

. 2016, "Recent Work on Saharan Rock Art." In Rock Arts Studies: News of the World Vol. 5, edited by Paul Bahn, 55-74. Oxford: Archaeopress.

Lenz, Oskar. “Timbouctou, Voyage au Maroc, au Sahara et au Soudan.” Paris: Hachette, 1886, 355. Quoted in Chouki El Hamel, Black Morocco: A History of Slavery, Race, and Islam. New York: Cambridge University Press, 2013.

Levtzion, Nehemiah. "North-West Africa: From the Maghrib to the Fringes of the Forest." In The Cambridge History of Africa Vol 4, from c. 1600 to c. 1790, Online Publication, edited by Richard Gray, 142-222. New York: Cambridge University Press, 2008. Accessed February 15, 2015. https://www-cambridge-org.ezproxy.fiu.edu/core/services/aopcambridgecore/content/view/FB8D962EC4A49BF9F15CA5479DF982F3/9781139054584c3 p142222 CBO.pdf/north-west-africa-from-the-maghrib-to-the-fringes-of-the-forest.pdf . FIU Online eBook.

. "The Western Maghrib and Sudan." In The Cambridge History of Africa Vol 3, from c. 1050 to c. 1600, Online Publication, edited by Roland Oliver, 331-462. New York: Cambridge University Press, 2008. Accessed February 15, 2015. http://universitypublishingonline.org.ezproxy.fiu.edu/cambridge/histories/popups/pdf vie wer.jsf?cid $=$ CBO9781139054577A009\&ref $=$ true \& pubCode $=$ CUP\&urlPrefix $=$ cambridge \&productCode $=$ cho. FIU Online eBook. 
López Bargados, Alberto. Arenas Coloniales: Los Awlad Dalim ante la Colonización FrancoEspañola del Sahará. Barcelona: Edicions Bellaterra, 2003.

López-Pozas Lanuza, José Carlos. “África Occidental Española: La Cuestión de la Soberanía y la Retirada del Sahara." PhD diss. Instituto Universitario General Gutiérrez Mellado, 2015. Accessed 03 September 2016. http://e-spacio.uned.es/fez/view/tesisuned:IUGM-Jclopez, Universidad Nacional de Educación a Distancia.

Lucas, A.J. "Considérations sur l'Ethnique Maure et en Particulier sur Une Race Ancienne: Les Bafours.” Journal de la Société des Africanistes Tome 1, Fascicule 2 (1931): 151-194.

Lydon, Ghislaine. On Trans-Saharan Trails: Islamic Law, Trade Networks, and Cross-Cultural Exchange in Nineteenth Century Western Africa. Los Angeles: Cambridge University Press, 2009.

Mahmud Awa, Bahía. "Generaciones Literarias: Intelectualidad y Política en el Sahara Occidental, 1850-1975." In Les Cahiers d'EMAM (Études sur le Monde Arabe et la Méditerrané) [Online] (24-25), Sahara Occidental: Mémoires, Culture, HistoiresCulture et Politique Series. 2015. Accessed June 18 2015. http://emam.revues.org/774.

Malainin, Chaya. Interview conducted with Director of the Interpretive Museum of the Ministry of Culture (Museo Interpretativo [Explicativo] del Ministerio de Cultura). 02 October 2014.

Marçais, Philippe W, George Horner, and Mark Karp. "Peoples and Cultures of North Africa." Annals of the American Academy of Political and Social Science, Vol. 298, Contemporary Africa Trends and Issues (March 1955): 21-29.

Martínez Lillo, Pedro and Silvio Arias Careaga, Caros Tanarro Alonso, Julia Weingartner (Coords.). Oficina de Acción Solidaria y Cooperación / Universidad Autónoma de Madrid. Universidad y Sahara Occidental: Reflexiones para la Solución de un Conflicto. Cuadernos Solidarios No. 6. Madrid: R.B. Servicios Editoriales, 2009.

Martínez Milán, Jesús Ma " "España en el Sáhara Occidental: De una Colonización Tardía a una Descolonización Inconclusa, 1885-1975." Anales de Historia Contemporánea 23 (March 2007): 365-383.

Massignon, Louis. "Le Maroc dans les Premières Années du XVI Siècle.” Tableau Géographique d'Après Léon L'Africain. Mémoires des la Société Historiques Algérienne. Algiers: Adolphe Jourdan, 1906. Map 3.6. 
McDougall, E. Ann. “On Being Saharan.” In Saharan Frontiers: Space and Mobility in Northwest Africa, edited by James McDougall and Judith Steel, 39-57. Indianapolis: Indiana University Press, 2012.

. "The Caravel and the Caravan: Reconsidering Received Wisdom in the SixteenthCentury Sahara." In The Atlantic World and Virginia, 1550-1624, edited by Peter C. Mancall, 143-169. Chapel Hill, NC: University of North Carolina Press, 2007.

McDougall, James and Judith Scheele, eds. Saharan Frontiers: Space and Mobility in Northwest Africa. Indianapolis: Indiana University Press, 2012.

McDougall, James. "Frontiers Borderlands, and Saharan/World History." In Saharan Frontiers: Space and Mobility in Northwest Africa, edited by James McDougall and Judith Scheele. Indianapolis, IN: Indiana University Press, 2012.

. 'Myth and Counter-Myth: 'The Berber' as National Signifier in Algerian Historiographies." Radical History Review, 86 (Spring 2003): 66-88.

McLaughlin, Glen W. "Ma' al-“Aynayn.” In Encyclopedia of African History, Volume 1 A-G, edited by Kevin Shillington, 869-870. New York: Fitzroy Dearborn and Taylor and Francis, 2005.

Mercedes García-Arenal and Miguel Ángel De Bunes, Los Españoles y El Norte de África Siglos $X V$-XVIII (Madrid: Editorial Mapfre, 1992)

Mercer, John. "Cycle of Invasion and Unification in Western Sahara." African Affairs 75, no. 301 (October 1976): 498-510. . Spanish Sahara. London: George Allen and Unwin Ltd., 1976.

Merry del Val, H. E. Señor Don Alfonso. "The Spanish Zones in Morocco (Continued)." The Geographical Journal, Vol. 55, No. 6. (Jun., 1920), 409-419.

Michel, Jonathan. "The Invasion of Morocco in 1591 and the Saadian Dynasty: An Examination of the Role of Europe in the Morocco Invasion of 1591 and the Rise to Power of the Saadian Dynasty." University of Pennsylvania, African-Studies Center. 1 December 1995. Accessed August 02, 2016. http://www.africa.upenn.edu/Articles_Gen/morco 1591.html. 
Migdalovitz, Carol. "Western Sahara: Status of Settlement Efforts." CRS Report for Congress. RS20962, September 29, 2006.

"Western Sahara: Status of Settlement Efforts." CRS Report for Congress. RS 20962, December 11, 2008.

. "Western Sahara: Status of Settlement Efforts." CRS Report for Congress. RS 20962, Augusts 19, 2009.

Millar, Fergus. "Local Cultures in the Roman Empire: Libyan, Punic and Latin in Roman Africa." The Journal of Roman Studies, Vol. 58, Parts 1 and 2 (1968): 126-134.

Miské, Ahmed-Baba. Front POLISARIO: L'Âme d'un Peuple. Paris: Éditions Rupture, 1978.

Mohamed Omar, Sidi. "The Right to Self-determination and the Indigenous People of Western Sahara." Cambridge Review of International Affairs 21, no. 1 (March 2008): 41-57.

Monès, H. 1988. "The Conquest of North Africa and Berber Resistance." In General History of Africa III: Africa from the Seventh to the Eleventh Century, $3^{\text {rd }}$ Ed., edited by M. El-Fasi, 224-245. Berkeley: University of California Press.

Moya Fernández, Conchi. Delicias Saharauis. No Place: Bubok Publishing, 2009. Google Play Books.

Mulero Clemente, Manuel. Los Territorios Españoles del Sahara y Sus Grupos Nómadas. Las Palmas de Gran Canaria. Spain: 'El Siglo' de Sánchez Talavera, 1945.

Mundy, Jacob. "Colonial Formations in Western Saharan National Identity." In North African Mosaic: A Cultural Reappraisal of Ethnic and Religious Minorities, edited by Nabil Boudraa and Joseph Kraouse (Newcastle, UK: Cambridge Scholars Publishing, 2007): 294-320.

Mundy, Jacob. "Western Sahara: The Question of Sovereignty." Conference on Multilateralism and International Law with the Western Sahara as Study. 12 December 2008.

Munene, Macharia. 2010. "History of Western Sahara and Spanish Colonisation.” In Multilateralism and International Law with Western Sahara as a Case Study, edited by Neville Botha, Michéle Olivier, and Delarey van Tonder, 70-98. Pretoria: University of South Africa Press. 
Mwalimu, Charles. The Golden Book: Philosophy of Law for Africa Creating the National State of Africa Under God, Volume I, Dynamic Jurisprudential Thought. New York: Peter Lang Publishing, 2010.

Newitt, Malyn. The Portuguese in West Africa, 1415-1670: A Documentary History. New York, Cambridge University Press, 2010.

Noakes, Greg and Janet McMahon. "Sahrawi Broadcaster Describes Western Sahara Freedom Struggle.” The Washington Report on Middle East Affairs 11, Issue 6 (January 31, 1993): 44.

Norris, H.T. The Arab Conquest of the Sahara: Studies of the Historical Events, Religious Beliefs and Social Customs which made the Remotest Sahara a Part of the Arab World. Essex, UK: Longman Group and Librairie du Liban, 1986.

Ohaegbulam, F. Ugboaja. "Ethical Issues in U.S. Policy on the Western Sahara." Mediterranean Quarterly (Fall 2002): 88-115.

Ould Mohamed, Abdel Kader. "La Tentación Canaria de los Mauritanos." In Culturas de Litoral: Dinámicas Fronterizas entre Canarias y la Costa Sahariano-Mauritana, edited by Alberto López Bargados and Jesús Martínez Milán, 235-251. Barcelona: Edicions Bellaterra, 2010.

Page, Willie F. Encyclopedia of African History and Culture: African Kingdoms (500 to 1500), Vol. II. New York: Learning Source, Ltd., 2001.

Pazzanita, Anthony G. 2006. Historical Dictionary of Western Sahara. Historical Dictionaries of Africa, No. 96. Lanham, MD: Scarecrow Press. Third Edition.

Pennell, C.R. Morocco since 1830: A History. New York: New York University Press, 2000.

Pham, J. Peter. "Not Another Failed State: Toward a Realistic Solution in the Western Sahara." The Journal of the Middle East and Africa 1 no. 1, (2010): 1-24.

Remco, Ensel. Saints and Servants in Southern Morocco. Boston: Koninklijke Brill NV, 1999.

Renan, Ernest. “Qu'est-ce qu’Une Nation?” Conférence Fait en Sorbonne, Le 11 Mars 1882. Deuxième Edition. Paris: Calmann Levy, 1882. 
Rézette, Robert. The Western Sahara and the Fontiers of Morocco. Paris: Nouvelles Editions Latines, 1975.

Robertson, Lawrence. "The Constructed nature of Ethnopolitics." International Politics 35, no. 3 (September 1997): 265-283.

Rodríguez Casado, Vicente. "Jorge Juan en la Corte de Marruecos." Biblioteca de Camarote de la Revista General de Marina Series 4. Madrid: Escelicer, 1941.

Roggio, Bill. "Syrian Jihadist Group Shal al-Islam Appoints New Leader.” The Long War Journal. www.longwarjournal.org. Accessed May 19, 2016. http://www.longwarjournal.org/archives/2016/04/syrian-jihadist-group-sham-al-islamappoints-new-leader.php .

San Martin, Pablo. "Nationalism, Identity and Citizenship in the Western Sahara." Journal of North African Studies. Vol 10, nos. 3-4 (September - December 2005): 565-592.

. November 16, 2013. "Nationalism, Identity and Citizenship in Western Sahara." Accessed June 9, 2015. http://www.sadr-emb-au.net/nationalism-identity-and-citizenshipin-western-sahara/. Saharawi Mission: Ethiopia-Africa Union website. http://www.sadremb-au.net/.

. Western Sahara: The Refugee Nation. Cardiff: University of Wales Press, 2010.

Schroeter, D. "Tāzarwālt." Encyclopaedia of Islam, Second Edition. Edited by P. Bearman, Th. Bianquis, C.E. Bosworth, E. van Donzel, W.P. Heinrichs. Brill Online. 01 July 2015. Accessed January 30, 2016. http://referenceworks.brillonline.com/entries/encyclopaediaof-islam-2/tazarwalt-SIM 7474 .

Seddon, David. "Morocco and Western Sahara." Review of African Political Economy. Politics and Imperialism no. 38, (April 1987): 24-47.

Shils, Edward. "Primordial, Personal, Sacred, and Civil Ties: Some Particular Observations on the Relationships of Sociological Research and Theory." British Journal of Sociology 8, no. 2 (June 1957): 130-145.

Smith, Anthony D. “When is a Nation?" Geopolitics 7, no. 2 (Autumn 2002): 5 -32.

Ethno-Symbolism and Nationalism: A Cultural Approach. New York: Routledge, 2009. 
Smith, Anthony D. Myths and Memories of the Nation. New York: Oxford University Press, 1999.

. National Identity. Las Vegas: University of Nevada Press, 1991.

. Nationalism. Second Edition. Cambridge, UK: Polity Press, 2010.

. The Nation in History: Historiographical Debates about Ethnicity and Nationalism. Hanover, NH: University of Press of New England, 2000.

Smith, William. 1854. "GAETU'LIA." Dictionary of Greek and Roman Geography. In Perseus Digital Library, edited by Gregory R. Crane. London: Walton and Maberly, 29 May 2014. http://www.perseus.tufts.edu/hopper/. Accessed July 24, 2014. http://www.perseus.tufts.edu/hopper/text?doc=Perseus:text:1999.04.0064:entry=gaetuliageo\&highlight=gaetulia .

Soler Subils, Joaquim. "Discoveries: Late Prehistorical Paintings in the Zemmur (Western Sahara)." International Newsletter on Rock Art, No. 45, 2006. www.inoraonline.org. Accessed July 13, 2016. http://www.bradshawfoundation.com/inora/discoveries $45 \quad 3 . \mathrm{html}$.

. "Sub-Zone 1: Mauritania - Western Sahara." In Rock Art of Sahara and North Africa. Paris: ICOMOS World Heritage Convention (June 2007): 15-28.

Spanish Wars. "Spanish Moroccan War: The Spanish Empire Seeks Expansion.” The Spanish War History. 2012. Accessed July 15, 2015. http://www.spanishwars.net/19th-centuryspanish-moroccan-war.html.

Trout, Frank E. Morocco's Saharan Frontiers. Bibliotheca Africana Droz 1. Geneva: Librairie Droz, 1969.

UN General Assembly, Question of Ifni and Spanish Sahara, 20 December 1966, A/RES/2229. Accessed 16 August 2016. http://www.refworld.org/docid/3b00f1d91c.html .

United Nations Treaty Collection. "Declaration of Principles on Western Sahara by Spain, Morocco and Mauritania." United Nations Treaty Series: Treaties and International Agreements Registered or Filed and Recorded with the Secretariat of the United Nations, Vol. 988, No. 14450. New York: United Nations, 1983. Accessed June 15, 2012. http://peacemaker.un.org/sites/peacemaker.un.org/files/MA-MRES 751114 DeclarationPrinciplesOnWesternSahara 0.pdf. 
United Nations. "Western Sahara." Geospatial Information Section: ICTD Department of Field Support Map No. 3175, Rev. 4, October 2012. www.un.org. Accessed May 27, 2016. http://www.un.org/Depts/Cartographic/english/htmain.htm.

Van Den Berghe, Pierre L. The Ethnic Phenomenon. Westport, CT: Praeger Publishers, 1987.

Webb Jr, James L.A. Desert Frontier: Ecological and Economic Change Along the Western Sahel, 1600-1850. Madison, WI: University of Wisconsin Press, 1995.

. "The Evolution of the Idaw al-Hajj Commercial Diaspora." Cahiers d'Études Africaines, vol. 35 nos. 138-139 (1995), 455-475.

. Desert Frontier: Ecological and Economic Change along the Western Sahel 16001850. Madison, Wisconsin: University of Wisconsin Press, 1995.

Wendt, Alexander. Social Theory of International Politics. New York: Cambridge University Press, 1999.

Whitcomb, Thomas. "New Evidence on the Origins of the Kunta." Bulletin of the School of Oriental and African Studies, Vol 38 no. 1 (1975): 103-123.

Willis, John Ralph. "The Writings of al-Hajj 'Umar al-Futi and Shaykh Mukhtar b. Wadi'at Allah: Literary Themes, Sources, and Influences.” In Studies in West African Islamic History, Volume I: The Cultivators of Islam, 177-210. New York: Routledge, 1979.

Wyrtzek, Jonathan. Making Morocco: Colonial Intervention and the Politics of Identity. Ithaca: Cornell University Press, 2015.

Yahya, Dahiru. Morocco in the Sixteenth Century: Problems and Patterns in African Foreign Policy. Harlow, Essex: Longman, 1981.

Zunes, Stephen and Jacob Mundy. Western Sahara: War, Nationalism, and Conflict Irresolution. Syracuse, NY: Syracuse University Press, 2010. 
VITA

\section{DAVID SUÁREZ}

Born, Boston, Massachusetts

1997

B.A., International Relations

Florida International University

Miami, Florida

1998

Research Assistant, Global-Event Data System (GEDS) Project

University of Maryland

College Park, Maryland

$1998-2000$

M.A., Conflict Resolution

University of Bradford

Bradford, England

2002-2003

2003-2004

United States Peace Corps

Bejaad, Morocco

Assistant Treasury Coordinator and Accountant

Assurant Solutions

Miami, Florida

2004-2006

Assistant Director of Education / Administration

Huntington Learning Center

Pembroke Pines, Florida

2006-2007

Corporate English Instructor

Talk International School of Languages

Ft. Lauderdale, Florida

2007-2010

Teaching Assistant

Florida International University

Miami, Florida

2009

Political and Economic Intern

U.S. Embassy

Rabat, Morocco

2009

Excellence of Service Award

Florida International University

Miami, Florida

2010

Summer Intern

U.S. Department of State

Near Eastern Affairs Bureau / Middle East Partnership Initiative Washington, D.C. 
Undergraduate Adviser

Florida International University

Miami, Florida

2011-2016

Adjunct Instructor

Florida International University

Miami, Florida

2012

Seminar Scholar

Institute of Humane Studies

2014

Summer Scholar

Intelligence Community Center for Academic Excellence

Program

2014-2015

Morris and Anita Broad Research Fellowship Award

Field and archival research

Spain and Algeria

$2007-2016$

Doctoral Candidate

Florida International University

Miami, Florida

\section{PUBLICATIONS AND PRESENTATIONS}

Suarez, D. 2014. "The Sahrawi - An Investigation of their 'National' Identity from Ancient Origins until 1524." Paper presented at the Seventh Annual Conference of the Association for the Study of the Middle East and Africa, Washington, D.C., October 30-November 1.

Suarez, D. 2013. "Kurdish Islamic Groups: An Account of their Growth and Uncertainty." Paper presented at the Sixth Annual Conference of the Association for the Study of the Middle East and Africa, Washington, D.C., November 21-23.

Suarez, D. 2012. "Imazighen Security: Why does Identity Matter in North Africa?" Paper presented at the Fifth Annual Conference of the Association for the Study of the Middle East and Africa, Washington, D.C., October 11-13.

Suarez, D. 2011. "Sahrawi Ethnonationalism: A Quest for Liberty." Paper presented at the $45^{\text {th }}$ Annual Meeting of the Middle East Studies Association. Washington, D.C., December 1-4.

Suarez, D. 2011. "The Transformation of Sahrawi Identity in the Face of Violent Conflict." Paper presented at the $54^{\text {th }}$ Annual Meeting of the African Studies Association. Washington, D.C., November 17-19. 